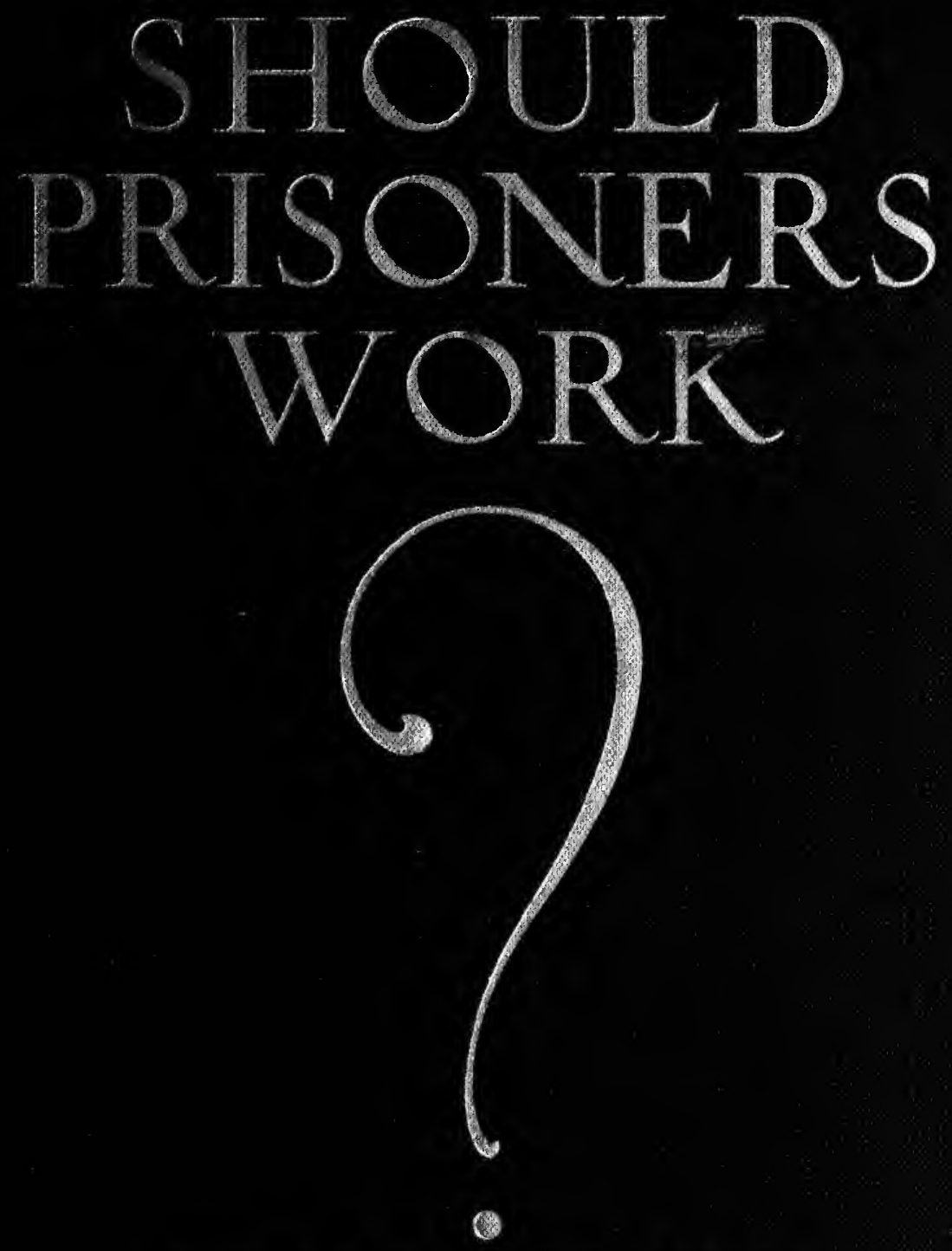

LOUIS +N-ROBNSON 
From the collection of the

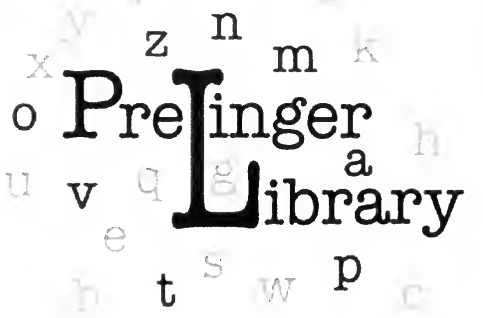

San Francisco, California 2006 
$1^{5} 1^{\infty}$ 
SHOULD PRISONERS WORK? 



\title{
SHOULD
}

\section{PRISONERS WORK?}

\author{
A Study of the Prison Labor \\ Problem in the United States
}

BY

LOUIS N. ROBINSON, Ph.D.

Lecturer in Economics and formerly Professor of Economics, Swarthmore College; Member of the Advisory Committee on Penal Institutions, Probation and Parole, of the National Commission on Law Observance and Enforcement; Investigator for the National Crime Commission; Member of the Pennsylvania Parole Commission and the Pennsylvania Crime Commission; Chairman of the Pennsylvania Committee on Penal Affairs.

Author of

"History and Organization of Criminal Statistics in the United States'

"Penology in the United States"

\section{THE JOHN C. WINSTON COMPANY CHICAgo PHILADELPHIA


Copyright, 1931, by

The John C. Winston Company

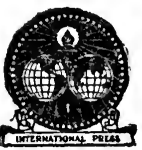

PRINTED IN THE U. 3. A.

AT THE INTERNATIONAL PRESS

The John C. Wington Co., Proprietora

Phiradelpeia 


\section{PREFACE}

In this study I have made an effort to explain the gap between the theory and the practice of employing our prisoners. It is necessary to have a goal toward which we may strive, but it is equally important to check up from time to time on what we are actually doing. The checking-up process not only stimulates us to further activity but also enables us to view the goal in a truer perspective. Social reformers, it seems to me, often allow their minds to advance from goal to goal without always realizing that in sober fact and practice their first objective has never been attained.

I owe much to those who have helped me in the writing of the book. I am particularly indebted to Carol Paxson Brainerd, my assistant, who has brought together facts and assisted materially in the preparation of the manuscript; also to Mr. E. R. Cass, General Secretary of the American Prison Association, Mr. Austin H. MacCormick, Assistant Director of the United States Bureau of Prisons, and Dr. George W. Kirchwey, of the New York School of Social Work, who have read the entire volume in 


\section{PREFACE}

manuscript and have given me the benefit of their broad knowledge and experience. As will be seen, I have relied heavily on the reports of the National Society of Penal Information for facts which cannot be had elsewhere. I have quoted freely from the works of many students of the problem - hoping thereby not only to present differing points of view in a given case, but to make accessible to the reader some of. the material which now lies buried in widelyscattered sources. Special thanks are due to the following persons and organizations for permission to reprint from copyrighted or manuscript works:

Professor Harry Elmer Barnes, author of The Evolution of Penology in Pennsylvania, and the Bobbs-Merrill Company, publishers;

Mr. Edward C. R. Bagley, Mr. Paul W. Garrett, and Mr. Howard B. Gill, who spoke before the New York State Crime Commission on November 21 and 22, 1929, and Mr. Herbert L. Smith, formerly secretary of the Commission, who supplied a manuscript copy of the unpublished minutes;

Honorable Theodore Christianson and Honorable Louis L. Emmerson, who spoke before the 1930 Governors' Conference, and The United States Daily, which published the "Official Proceedings of the Twenty-Second Annual Conference of Governors";

Professor John R. Commons and Dr. John B. Andrews, authors of Principles of Labor Legislation, and Harper \& Brothers, publishers;

Mr. Joseph F. Fishman, author of Crucibles of Crime; 


\section{PREFACE}

Dr. and Mrs. Sheldon Glueck, authors of 500 Criminal Careers, and Alfred A. Knopf, Inc., publishers;

Mrs. Jessie D. Hodder, and the National Conference of Social Work, in whose Proceedings for 1920 is published Mrs. Hodder's article, "The Psychopathic Delinquent Woman";

The National Society of Penal Information, Inc., publishers of the Handbook of American Prisons and Reformatories: 1929, and Mr. Paul W. Garrett and Mr. Austin H. MacCormick, the editors;

The New York Times.

State and local officials have answered my numerous letters with painstaking care, so that in one sense this is a composite book to which many persons have contributed. Nevertheless, I must accept the responsibility for the point of view presented in the pages which follow.

It is my earnest hope that this book may serve to increase the interest of our citizens in the employment of prisoners. We send a man to prison without knowing and without caring what becomes of him once the doors close behind him. There are few to speak for him now, but there would be more if only it were seen that in pleading his case one is really speaking for the true interests of society as a whole.

Louis N. Robinson 


\section{TABLE OF CONTENTS}

CHAPTER

PAGE

Preface.............................. iii

Table of Contents................... vii

List of TABLES....................... xi

I. Should Prisoners Work?.............. I

II. Extent of Employment and UnemployMENT in Prisons.................. 5 The Situation in State and Federal Institutions...................... 5

I. Data from Federal Sources......... 5

2. Figures from the 1929 Handbook..... 9

3. What the Figures Are Worth....... I6 Idleness in Institutions for Misdemeanants 24 I. Data for Eighteen States (Obtained by Questionnaire)............. 25

2. Jail Employment in the Rest of the Country.................... 33

3. The Picture as a Whole.......... 40

III. The Causes of Unemployment in Prisons 44 Poor Management in Its Various Forms... 44 Prison Labor in Competition with Free Industry.................... 48

The Extent of Prison Competition....... 52

The Attitude of Union Labor.......... 6r

The Attitude of Manufacturers......... 69

Opposition from Other Quarters......... 77

IV. Systems of Employing Prisoners....... 79

Definitions.................... 79

Present Distribution of Prison Workers by Systems...................... 82

The Lease System............... 87 


\section{TABLE OF CONTENTS}

CHAPTER

PAGE

The Contract System............... 90

The Piece-Price System. . . . . . . . . . . 94

The State-Account System............. 95

The State-Use System................ 98

The States-Use System............ I04

Recent Legislation Affecting Prison Labor. 108

Early Results of the Hawes-Cooper Act... II 3

The Public-Works-and-Ways System...... II

Summary..................... 122

V. Problems of Prison Industrial Manage-

MENT...................... 125

Ordinary Economic Factors........... I 26

I. Climate................... 127

2. Raw Material................ 127

3. Available Market.............. I29

4. Freight Rates................. I3

5. Capital Outlay................ I $3^{2}$

Selling the Products................ I33

The Labor Supply.................. I 36

Classification Studies................ I $3^{8}$

I. The New York Classification Scheme I4I

2. The New Jersey Classification Scheme 145 The Right Job for Each Prisoner........ I48

Vocational Training................. 156

Job Analysis................... I66

Maintenance Requirements............ I68

Divided Management.............. I7I

Finding Work for Misdemeanant Pris-

oners....................... I76

VI. Costs, Wages, and Profits of Prison Labor 185

Price Fixing .................... 185

I. By Legislative Fiat............. 185

2. On the Basis of Costs............ 186

Iabor Costs vs. Penological Costs........ 187

The Revolving Fund.............. 190

Practice and Theory of Separating Costs.. 195 


\section{TABLE OF CONTENTS}

CHAPTER

PAGE

Wages Now Paid to Prisoners........... I98

I. In Local Institutions.............. I99

2. In State and Federal Institutions.... 201

Basis of Wage Payments. . . . . . . . . . 209

Theoretical Basis for Wages........... 212

Compensation for Industrial Injuries..... 221

Prison Profits.................. 227

1. Gross and Net Per Capita Costs..... 228

2. Earnings and Expenses of Various Institutions and Prison Systems....... 235

VII. What Work Has Been Found for Pris-

ONERS?................... 248

In Local Institutions (Jails, Workhouses,

Houses of Correction)........... 248

I. Jobs Now Available............ 249

2. Jobs That Might Be Done........ 26I

Jobs in State and Federal Institutions (Prisons or Penitentiaries, Adult Reformatories)................... 262

Extent of Road Work as a Prison Occupation........................ 270

How Prison Industries Have Been Selected 276 Building Construction by Prison Labor.... 279 Opposition to Specific Trades or Industries 280 Jobs Prisoners Might Do (State and Federal

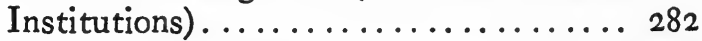

VIII. Conclusions.................. 289

ApPEndix I. ....................... 303

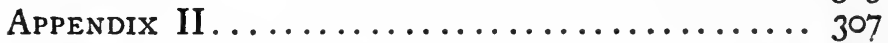

APPENDIX III......................... $3^{I I}$

Bibliography........................ $3^{\mathrm{I}} 3$

INDEX ............................ 343 



\section{LIST OF TABLES}

PAGE

I. Prison Employment in 1923: State and Federal Institutions.......... 6

II. Productive Employment, 1885 to 19236

III. Extent of Employment and UNEMployment in State and Federal Penal and Correctional InstituTIONS, $1927-28 \ldots \ldots \ldots \ldots \ldots \ldots$

IV. EMPLOYMENT aNd UNEMPLOYMENT, I923 то $1928 \ldots \ldots \ldots \ldots \ldots \ldots \ldots$ I6

V. Employment in Institutions for MisDEMEANANTS, I $928-30 . \ldots \ldots \ldots \ldots 26 \mathrm{a}$

VI. Prison Commitments in the United States, January I to June 30, 192343

VII. Comparison of Prison and Free ProDUCtion in Certain Lines for Which the Figures Seem to Be Reasonably Comparable, 1923.......... 55

VIII. Comparison of Prison and Free Production in Certain Lines for Which the Figures Are Not Strictly ComPARABLE, I $923 \ldots \ldots \ldots \ldots \ldots \ldots \ldots . \ldots \ldots$

IX. Comparison of Prison and Free ProDUCTION IN NEW YORK, I929....... 59

$\mathrm{X}$. Distribution of Employment in State and Federal Penal and CorrecTIONAL INSTITUTIONS, $1927-28 \ldots \ldots .83$

XI. Systems of Prison Employment, I923 AND $1928 \ldots \ldots \ldots \ldots \ldots \ldots \ldots, 85$ 


\section{LIST OF TABLES}

PAGE

XII. Check List: Systems of Employment in State Penal and Correctional Institutions................. I 23

XIII. Classification of Types-New York State Prisoners.............. I42

XiV. Classification of Types-New Jersey State Prisoners............... I 47

XV. Comparison of Classifications....... I 49

XVI. Vocational Possibilities-I,515 New York Prisoners................ 157

XVII. Classification of I,288 MisdemeanANTS IN NEW York............ I 78

XVIII. Relation of Industrial Earnings to Prison Accounts in 99 Institutions 190 XIX. Wages Paid to County and Municipal Prisoners, 1929-30............ 200 XX. Prisoners Receiving Wages in State and Federal Institutions, I927-28 202 XXI. Prisoners Receiving Wages in New YoRK, $1930 \ldots \ldots \ldots \ldots \ldots \ldots .218$ XXII. Per Capita Costs and Earnings in 20 Institutions................ 230 XXIII. Per Capita Costs and Earnings in Massachusetts................ 233

XXIV. Types of Work in Local Institutions 250 XXV. Occupational Opportunities in DisTRICT of Columbia Institutions.... 259

XXVI. Types of Prison Industrial Production (State and Federal InstituTIONS) $\ldots \ldots \ldots \ldots \ldots \ldots \ldots \ldots . \ldots 263$

XXVII. Maintenance and Construction Trades (State and Federal InstiTUTIONS) .................. 264

XXVIII. The Use or Prison Labor for Road

Construction................. 272 


\section{I}

\section{SHOULD PRISONERS WORK?}

Should the men and women confined in prison have work, or should compulsory idleness under undesirable conditions be a part of the penalty inflicted for crime?

The man in the street has no doubts about the matter: prisoners should work, and work hard, because they are being punished. In other words, he believes that work is an essential part of punishment or a punishment additional to that of imprisonment, which of itself is insufficient. This theory of the relation of work to punishment is as old as the story of Adam, on whom God laid the penalty of work for disobedience, and it is reflected in the ordinary sentence to "imprisonment at hard labor."

The penologist, too, believes in work for prisoners, but he gives more than one reason for his opinion. In the first place, he thinks there is some curative power in good honest work, that through it body and mind may be cleansed of impurities and habits may be established which will prove useful on release. Conversely, idleness is most demoralizing to human beings. 
"Those who have visited prisons frequently," says E. R. Cass, General Secretary of the American Prison Association, "are unanimous in the opinion that idleness in a prison is subversive of discipline and hurtful to the moral, intellectual and physical well-being of the inmates. No greater cruelty can possibly be inflicted on prisoners than enforced idleness. . . Their health declines and in a large proportion of cases the mind, burdened by the monotony of the slowly passing hours in which neither hand nor brain is active, becomes affected."1

Now a criminal turned out of prison a more demoralized character than when he entered is rather certain to revert to crime. Thus the whole social action of arrest, trial, and punishment is frustrated, for its plain purpose is to hinder-not. to foster-crime.

The penologist would also call atten tion to the group of prisoners who until confined provided the bread and butter for their families. Why, he asks, should the burden of caring for these dependents be placed on others - as it will be if the prisoners are not allowed to work and to earn - and why break the economic bonds of family life that are often all-important in keeping men upright? Furthermore, there are some crimes in which the wrong done should obviously be repaired, at least in part, by the payment of money to the injured party. Probationers are often required, as one of the conditions of their

1 "Prison Labor," paper read at National Conference on the Reduction of Crime, 1927; cf. Prison Association of New York, 83rd Annual Report (I927), p. 82. 
probation, to do this very thing. A wholesome lesson to many a criminal would be the necessity of compensating his victim by money earned at hard work in prison.

Every warden knows that a prison full of idle inmates is extremely difficult to administer. Z. R. Brockway, the famous exponent of the adult reformatory system, kept his men busy not only with work but with drill, schooling, lectures, and industrial training. But Brockway was an exceptional prison administrator and a man of prodigious energy, and he was dealing with a selected group of young adults. For the common run of prisoners the penologist insists that work should form the foundation of training and care.

Then too it costs money to hold a man in prison, even for a short time. Only on the ground that some state purpose will be serveda purpose higher than any of those already mentioned-can the maintenance at the state's expense of a non-working prison population be justified.

Is there anyone who believes that prisoners should not work? Few will confess to any such opinion. There are many, of course, who object to overworking prisoners and to making those in ill health perform impossible tasks. Practically all observers of prison life see, also, the necessity of devoting some time to vocational training and to general education, even if this decreases the G.P.W. -2 


\section{SHOULD PRISONERS WORK?}

time that might be given to productive labor. Yet those who hold these points of view are not opposed to, but heartily in favor of, the general principle that work is the basis of most correctional methods, and effective vocational training requires that the student take some part in really productive work. Seemingly, there is no one who does not recognize for one reason or another the fact that work should be provided for prisoners. 
II

\section{EXTENT OF EMPLOYMENT AND UNEMPLOYMENT IN PRISONS}

Since there are so many good reasons why prisoners should work, one would naturally expect to find every able-bodied man in custody employed. Is this the case in our penal institutions today?

The Situation in State and Federal INSTITUTIONS

1. Data from Federal Sources. We are confronted at the outset with a lamentable lack of statistics, as is always the case in studying crime and criminals in this country. The Federal Government, through its Department of Labor, has periodically but at long intervals collected certain facts on the employment of prisoners. ${ }^{1}$ The most recent study, published in 1925 by the Bureau of Labor Statistics, ${ }^{2}$ gives the following figures

1 Commissioner of Labor, 2nd Annual Report, I886 (Washington, 1887). "Convict Labor," Bulletin of the Department of Labor, No. 5 (1896), pp. 443-78. Commissioner of Labor, 20th Annual Report, I905 (Washington, 1906). Federal and State Laws Relating to Convict Labor (Senate Document No. 494; Washington, 1914). Convict Labor in 1923 (Bulletin No. 372, Bureau of Labor Statistics; Washington, 1925). "State Convict Labor Legislation," Monthly Labor Review, XXVIII (March I929), 126-37.

2 Convict Labor in 1923. 


\section{SHOULD PRISONERS WORK?}

for IOI state and Federal adult penal institutions in 1923:

TABLE 1

Prison Employment in 1923: State and Federal Institutions*

Average number of prisoners. .................... Per CEnT

Average number productively employed................

Average number employed at institutional work..... 25,127 30

Average number sick.................... 2,602 3

Average number idle...................... 5,233

* Convict Labor in 1923, p. 2.

A historical table compiled from five of the Federal reports ${ }^{1}$ shows, after eliminating data for non-comparable institutions, that in state and Federal penal institutions for adults the percentage of convicts employed at productive labor declined from 75 in 1885 to 61 in 1923 :

\section{TABLE II}

Productive Employment, 1885 to 1923

Percentage employed at pro$\begin{array}{lllll}1885 & 1895 & 1905 & 1914 & 1923\end{array}$ ductive labor........... $75 \quad 72 \quad 65 \quad \begin{gathered}\text { reported) } \\ \text { ri }\end{gathered}$

Percentages of idleness, illness, and nonproductive employment comparable to those of 1923 are not given in the earlier reports. Nor do any of the Federal figures just quoted in Tables I and II cover employment in county or municipal institutions, which on January I, 1923, were housing 23.8 per cent - nearly one fourth - of all prisoners in the United States. ${ }^{2}$ (The high per-

1 Convict Labor in 1923, p. 17.

2 Bureau of the Census, Prisoners: 1923 (Washington, 1926), p. I3. 


\section{EXTENT OF EMPLOYMENT}

centage of idleness in local institutions will be discussed presently.)

To supplement the I 923 study made by the Bureau of Labor Statistics, the Department of Commerce issued in 1929 a report including data on the number of prisoners productively employed during the calendar year 1926 or the fiscal year closest to it. ${ }^{1}$ Eighty-six state and Federal adult penal institutions are listed, but the returns are incomplete, since only twenty-six states reported the employment item fully for all adult institutions and three did not report it at all. By adding the returns from the sixtyseven of these institutions for which we can also learn the average populations, we get a total of 34,886 prisoners employed at productive work in 1926 or the fiscal year most closely corresponding to it. (For fourteen of the sixty-seven, employment data are incomplete.) The average population of the same institutions is given as 70,377 in the 1926 census of prisoners. ${ }^{2}$ Thus in sixty-seven institutions representing thirtyeight states and the Federal Government, only 50 per cent of the prisoners were productively employed in 1926. (This is to be compared with 6r per cent so employed in I923.) Of the ten states not represented in our 1926 data, six

${ }^{1}$ Prison Industries (Domestic Commerce Series No. 27; Washington, 1929), pp. 71, 97-105.

2 Bureau of the Census, Prisoners in State and Federal Penal Institutions: 1926 (Washington, 1929). 
usually report most of their prisoners employed, a fact which would tend to raise the percentage had we complete information. ${ }^{1}$ It is safe to assume that no improvement in the extent of productive prison employment in institutions for long-term offenders occurred between I923 and 1926. There may even have been a decrease.

Early in 1929 a special Congressional committee presented a report covering Federal penal and correctional institutions and some of the local jails in which Federal prisoners are confined throughout the country. ${ }^{2}$ It contains detailed reports on employment at Atlanta, Leavenworth, McNeil Island, and Chillicothe, also some data on the District of Columbia penal institutions and on local jails which receive Federal prisoners. Work sheets of December, 1928, for the three Federal prisons, one road camp, and Chillicothe Reformatory showed a total population of $8,6 \mathrm{II}$, with 22 per cent productively employed, 67 per cent employed at institutional work, 5 per cent incapacitated, and the remaining 5 per cent idle. ${ }^{3}$

1 The ten states not represented are Alabama, Arkansas, Delaware, Florida, Georgia, Idaho, Nevada, New Mexico, Texas, and Utah. The prisoners of six (Alabama, Arkansas, Delaware, Florida, Georgia, Texas) are generally - in reports of individual institutions, in the 1923 study referred to, and in other data next to be considered - listed as employed; all of the six but Delaware have large prison populations.

2 Federal Penal and Reformatory Institutions: Hearings before the Special Committee . . pursuant to H. Res. 233 (Washington, 1929).

3 Ibid., pp. I9-22. 
This and the other publications just discussed represent the sum total of Federal information on prison employment. So far as we can learn, only one state, Massachusetts, publishes comprehensive, well-summarized, and easily accessible figures on this subject for all its institutions, although something can usually be gleaned from the published reports of the individual institutions in each state.

2. Figures from the "1929 Handbook." Interesting but unsummarized information on employment in state and Federal penal and correctional institutions for adults is contained in the Handbook of American Prisons and Reformatories published in 1929 by a private philanthropic organization, the National Society of Penal Information. ${ }^{1}$ This volume will be referred to hereafter in these pages as the "I929 Handbook," or simply "the Handbook." Five Federal and ninety-four state institutions are included, covering all forty-eight states and all but eleven ${ }^{2}$ of

\footnotetext{
${ }^{1}$ Paul W. Garrett and Austin H. MacCormick, ed., Handbook of American Prisons and Reformatories: 1929 (New York, 1929).

${ }^{2}$ Of those eleven, two (New Jersey Reformatory, Annandale; Massachusetts State Prison Colony) are new institutions developed since the data were gathered for the Handbook; five (Illinois State Farm, Indiana State Farm, Massachusetts Prison Camp and Hospital, Massachusetts State Farm, North Carolina Industrial Farm Colony for Women) are wholly or in part for misdemeanants; and four (Arkansas State Farm for Women; Albion State Training School, New York; Vermont State Prison and House of Correction for Women; Wisconsin Industrial Home for Women) are women's institutions. Three hospitals for insane criminals (Dannemora and Matteawan State Hospitals, New York; Lima State Hospital for Criminal Insane, Ohio) are also listed by the Prison Association, but not included in the Handbook.
} 
the adult state penal institutions listed officially by the American Prison Association in April, 1930. The District of Columbia Reformatory is not included. The reports are arranged alphabetically by states.

The Handbook figures are not average figures for a given year. They represent, in the case of each prison or reformatory, the population and the industrial distribution as reported for the day on which the institution was visited by the representatives of the National Society of Penal Information. All but ten of the visits were made at some date between November, 1927, and July, I928; eight of those ten took place before the end of 1928 and the remaining two in May and August, 1929. On the whole, therefore, the published data refer to the nine-month period ending in July, 1928, or we might say to the year ending August I, I928. By combining the figures relating to individual institutions, we have prepared Table III.

Our summary of the various reports lists 67,646 , or 58 per cent of the total penal population, as productively employed and $34,69 \mathrm{r}$, or 29 per cent, as employed at institutional work. We find further that 12,452 are not working for one reason or another-illness, incapacitation (mental or physical), punishment, school, lack of work, etc. Out of the 12,452 there are 5,396 reported as definitely idle; this means that 5 
per cent of the total population, while presumably not at all incapacitated (since those sick or otherwise disabled are usually listed

TABLE III

Extent of Employment and Unemployment in State and Federal Penal and Correctional Institutions

\begin{tabular}{|c|c|c|c|c|c|c|}
\hline & $\begin{array}{c}\text { Total } \\
\text { Penal } \\
\text { Popu- } \\
\text { Lation }\end{array}$ & $\begin{array}{c}\text { PrODUC- } \\
\text { TIVELY } \\
\text { EM- } \\
\text { PLOYED }\end{array}$ & $\begin{array}{c}\text { EM- } \\
\text { PLOYED } \\
\text { ON } \\
\text { MAIN- } \\
\text { TENANCE }\end{array}$ & $\begin{array}{l}\text { Not } \\
\text { WORK- } \\
\text { ING }\end{array}$ & $\begin{array}{c}\text { DEFI- } \\
\text { NITELY } \\
\text { IDLE }\end{array}$ & $\begin{array}{l}\text { Not } \\
\text { AccouNTED } \\
\text { FOR }\end{array}$ \\
\hline $\begin{array}{l}\text { Eastern } \\
\quad \text { (9 States).... } \\
\text { Southern } \\
\quad \text { (16 States)... } \\
\\
\text { Middle Western } \\
\quad \text { (I } 2 \text { States)... } \\
\text { Western } \\
\text { (I I States)... }\end{array}$ & $\begin{array}{r}39,847 \\
\text { I } 2,927\end{array}$ & $\begin{array}{r}8,896 \\
45 \% \\
29,033 \\
78 \% \\
20,98 \mathrm{r} \\
53 \% \\
6,659 \\
52 \%\end{array}$ & $\begin{array}{r}6,660 \\
34 \% \\
5,415 \\
15 \% \\
12,771 \\
32 \% \\
4,868 \\
37 \%\end{array}$ & $\begin{array}{r}2,495 \\
13 \% \\
2,472 \\
7 \% \\
5,204 \\
13 \% \\
1,380 \\
11 \%\end{array}$ & $\begin{array}{r}693 \\
4 \% \\
\\
391 \\
1 \% \\
\\
3,025 \\
8 \% \\
849 \\
7 \%\end{array}$ & $\begin{array}{c}1,521 \\
8 \% \\
212 \\
\text { Less than I \% } \\
891 \\
2 \% \\
20 \\
\text { Less than } 1 \%\end{array}$ \\
\hline All 48 States... & 109,478 & $\begin{array}{r}65,569 \\
60 \% \\
2,077 \\
26 \%\end{array}$ & $\begin{array}{r}29,714 \\
27 \% \\
4,977 \\
63 \%\end{array}$ & $\begin{array}{r}\text { I I }, 551 \\
\text { II } \% \\
901 \\
\text { II } \%\end{array}$ & $\begin{array}{r}4,958 \\
5 \% \\
\\
438 \\
6 \%\end{array}$ & $\begin{array}{r}2,644 \\
2 \% \\
\ldots .\end{array}$ \\
\hline Total. . & I I 7,433 & $\begin{array}{r}67,646 \\
58 \%\end{array}$ & $\begin{array}{r}34,691 \\
29 \%\end{array}$ & $\begin{array}{r}12,452 \\
11 \%\end{array}$ & $\begin{array}{r}5,396 \\
5 \%\end{array}$ & $\begin{array}{r}2,644 \\
2 \%\end{array}$ \\
\hline
\end{tabular}

separately on the same work sheets), admittedly have nothing to do but sit in cells, lounge in "bull pens," or stroll about recreation yards. The percentage is undoubtedly too small - it represents a minimum.

However, accepting the figures at their face value for the time being, it will be illuminating 
to consider and compare the geographical groups. ${ }^{1}$ The Middle West has the largest penal population and the South the next largest, while the West, as would be expected, has the smallest. In percentage productively employed, the South ranks first ( 78 per cent), the Middle West a poor second ( 53 per cent), the West third (52 per cent), and the East last (45 per cent). The relatively large number $(\mathrm{I}, 52 \mathrm{I})$ unaccounted for in the eastern group is chiefly responsible for its poor showing. The West obviously tries to fill the employment gaps with maintenance jobs and employs 37 per cent at such work; the East also has 34 per cent in this class and the Middle West 32 per cent; the South, intent on production, keeps its maintenance forces almost to a minimum - I 5 per cent.

If we look at the matter from the point of view of absolute idleness and ask how many have not even maintenance work to do, the South still has the best record, with only I per cent reported idle, but the East is now second (4 per cent), the West third ( 7 per cent), and the Middle West fourth (8 per cent).

Federal prisons reported only 26 per cent productively employed, 63 per cent on maintenance jobs, and 6 per cent idle, figures which should

1 The eastern states include nine (the New England and Middle Atlantic divisions of the census); the southern group includes sixteen (South Atlantic, East South Central, and West South Central divisions); the middle western, twelve (East North Central and West North Central divisions); the western, eleven (Mountain and Pacific divisions). 
be compared with the Federal data already quoted for the month of December (I928) alone. $^{1}$ The Federal percentages in Table III affect the totals appreciably, decreasing the proportion productively employed and increasing the proportion assigned to institutional work. (Since I928, employment conditions in Federal institutions have improved.)

The geographical classification has interest and significance because of differences in type of employment and attitude toward prison labor. The East and Middle West maintain large industrial prisons and are half afraid - or else not allowed - to use their convict labor for fear of injuring free industry. The West has more small prisons, spends less money for penal purposes, and has fewer prison industries altogether. The South has farm prisons and does road work, supplementing with industrial prisons, and has no scruples against making a profit by either contract labor or state account.

Examining the results by states, ${ }^{2}$ we discover that only three eastern states (Connecticut, New Hampshire, Rhode Island) report more than 70 per cent of their prisoners to be productively employed; two (Massachusetts and Vermont) have between 60 and 65 per cent, and the other four (Maine, New Jersey, New York, Pennsyl-

1 Cf. p. 8 above.

${ }^{2}$ Cf. Appendix I for complete table by states. 


\section{I4 SHOULD PRISONERS WORK?}

vania) have from 35 to 45 per cent of their prisoners at productive work.

Only one southern state (Delaware) has as few as 32 per cent of its prison population assigned to production jobs, and the reason in this case is that the New Castle County Workhouse takes a number of untried prisoners, who do not work. The next lowest percentage of productive employment in the South is 57 (Oklahoma); three states (Florida, Maryland, West Virginia) have percentages between 60 and 70, three (Kentucky, South Carolina, Tennessee) fall between 70 and 80, four (Alabama, Louisiana, Texas, Virginia) between 80 and 90 , and four (Arkansas, Georgia, Mississippi, North Carolina) have 90 per cent or more of their prisoners productively employed. As the Handbook editors were unable in all cases to obtain absolutely exact reports of the number imprisoned and the work distribution in southern institutions, figures for this group of sixteen states are sometimes approximate; but it is safe to say that the percentages just given, whether estimated or actual, are far higher than those in any other part of the country.

If we rank the middle western states in order of the greatest percentage of prisoners productively employed, only two (Nebraska, Wisconsin) are as high as 70; four (Illinois, Indiana, Iowa, Missouri) are between 60 and 70; Min- 
nesota's percentage is 56 ; four (Kansas, Michigan, North Dakota, Ohio) range from 35 to 50 . The situation in South Dakota - not one man assigned to productive work - is to some extent temporary, as the penitentiary twine plant was not running at the time of the report. It ordinarily employs 40 to 50 per cent of the population, and during 1927 and 1928 ran eleven months out of twelve. ${ }^{1}$

Classifying the western group in the same way, two states (New Mexico and Wyoming) report percentages over 70; two (California and Idaho) are in the 6o's; Utah reports $5 \mathrm{I}$ per cent productively employed and Colorado 42 per cent; while three (Montana, Oregon, Washington) are between 35 and 40 and Arizona has as few as 22 per cent of its penal population productively employed. In Nevada not a single prisoner is reported to be doing productive work.

It is interesting to compare the Handbook percentages in Table III with those obtained from the other sources already mentioned. (See Table IV.)

We note that the percentages of complete idleness and institutional employment in state and Federal institutions combined have remained almost constant from 1923 to 1928 , while the percentage of productive employment has appar-

${ }_{1}$ 1929 Handbook, p. 89I. Board of Charities and Corrections, 20th Biennial Report (1927-28), p. 42. 


\section{I6 SHOULD PRISONERS WORK?}

ently decreased somewhat. Not less than 50 and not more than 6i per cent of all adult prisoners in state and Federal penal and correctional institutions were assigned to productive work in the five years ending 1928.

TABLE IV

EMPloyment AND UNEMPLOYMENT, I923 TO I928

\begin{tabular}{|c|c|c|c|c|c|c|}
\hline$Y_{\text {EAR }}$ & $\begin{array}{c}\text { NUMBER } \\
\text { OF STATE } \\
\text { AND } \\
\text { FEDERAL } \\
\text { INSTITU- } \\
\text { TIONS }\end{array}$ & $\begin{array}{c}\text { PER- } \\
\text { CENTAGE } \\
\text { AT } \\
\text { ProduC- } \\
\text { TIVE } \\
\text { WORK }\end{array}$ & $\begin{array}{c}\text { PER- } \\
\text { CENTAGE } \\
\text { AT } \\
\text { INSTITU- } \\
\text { TIONAL } \\
\text { WORK }\end{array}$ & $\begin{array}{c}\text { Per- } \\
\text { CENTAGE } \\
\text { INCAPAC- } \\
\text { ITATED }\end{array}$ & $\begin{array}{c}\text { Per- } \\
\text { CENTAGe } \\
\text { IDLE }\end{array}$ & $\begin{array}{c}\text { PER- } \\
\text { CENTAGE } \\
\text { UNAC- } \\
\text { COUNTED } \\
\text { For }\end{array}$ \\
\hline 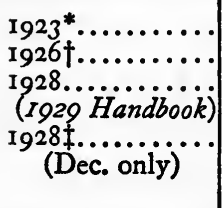 & $\begin{array}{c}\text { IOI } \\
67 \\
99 \\
5 \\
\text { (Federal } \\
\text { only) }\end{array}$ & $\begin{array}{l}61 \\
50 \\
58 \\
22\end{array}$ & $\begin{array}{l}30 \\
\ddot{29} \\
67\end{array}$ & $\begin{array}{l}3 \\
-6 \\
5\end{array}$ & $\begin{array}{r}6 \\
\cdots \\
5 \\
6\end{array}$ & $\begin{array}{r}\ddot{50} \\
2 \\
\cdots\end{array}$ \\
\hline
\end{tabular}

* Convict Labor in 1923, p. 2; cf. p. 6 above.

$\dagger$ Prison Industries, pp. 71, 97-105; Prisoners: 1926, pp. 128-32; cf. pp. 7, 8 above.

$\ddagger$ Federal Penal and Reformatory Institutions, pp. 19-22; cf. p. 8 above.

3. What the Figures Are Worth. In evaluating figures derived from Federal reports and from the Handbook, it is essential not only to read between the lines but also to check against these figures the information to be found in reports published by individual institutions and in other sources of all kinds, such as the findings of legislative committees and individual observers.

Most officials are loath to admit the extent of idleness within their institutions, and some 
attempt to cover it up. They feel - and justly, so it would seem - that idleness reflects on their ability to run the institution, or on the party in power, the one to which they usually belong. Official work sheets and reports, therefore, do not give an accurate picture of the employment situation. For example, if a man is once assigned to a certain detail it is customary to list him as working, whether or not he has anything much to do. None of the large New York prisons (Auburn, Great Meadow, Clinton, Sing Sing) reported to the Handbook editors much idleness per se: the difficulty in these institutions is to know how many of the men said to be working are really occupied. A Sub-Commission on Penal Institutions of the New York State Crime Commission reported in 1927 that 3,000 out of 6,000 convicts were "idle practically all of the time." 1 Extremely short workdays are often arranged in order to provide work for many. The South Dakota Penitentiary had all its men on 4-hour shifts in $1929,{ }^{2}$ and in Pennsylvania, "in order to give work to as many as possible, the jobs are divided, and a full day's work is given to few of the inmates." 3 In a vain attempt to meet the situation, prison officials constantly resort to overassignment. Two and three times as many

1 Report to the Commission of the Sub.Commission on Penal Institutions (Albany, 1927), pp. 5, 9.

2 American Year Book (1929), p. 493.

${ }^{3}$ Pennsylvania Commission on Penal Institutions, Report (I93I), p. I4. 
men are assigned to a task or to a machine as would be used in a private organization outside.

Maintenance details in particular are often greatly overmanned just for the sake of giving some work to as many as possible. Perhaps half or a quarter of a job is better than none, but when an institution numbering some 1,100 inmates assigns 442 to maintenance jobs, ${ }^{1}$ it is impossible to be impressed by its claim that 95 per cent of its able-bodied men are employed. ${ }^{2}$ Examining the San Quentin work sheets for the year ending June $30,1928,{ }^{3}$ we find that the daily average employed at productive labor was 2,064 and the daily average at nonproductive I, 5 I 4 , without counting I 54 excused from work. A plant the size of this one of course requires a large number of maintenance workers, but the overassignment seems obvious; it took an average of 90 men a day to keep the flower gardens in shape; 43 , on the average, were assigned to the stables and garage, and 46 to the water front as stevedores. Using the New York Prison Survey Committee's estimate of $12 \mathrm{r} / 2$ per cent for maintenance needs, 4447 men would

1 rg20 Handbook, p. 184.

2 Colorado State Penitentiary, 26th Biennial Report (1927-28), p. 42.

${ }^{8}$ California State Board of Prison Directors, Biennial Report (I927-28), pp. $59-6 \mathrm{I}$.

- That is, 125 men out of each 1,000 ; in larger groups the maintenance percentage might conceivably be reduced under efficient management. Cf. Prison Survey Committee, Report (Albany, 1920), p. I26. 
have been able to do the work of the $\mathrm{I}, 5 \mathrm{I}_{4}$, who aggregate $4 \mathrm{I}$ per cent.

Overassignment in state-managed productive industries is found almost universally in the prisons. Commenting on the industrial situation at San Quentin, the authors of the 1929 Handbook remark:

All that can be said for most of the industries is that they keep part of the inmates partly busy part of the time. The jute mill, which employs I roo men, is treadmill labor that can be justified only on the ground that it is better than idleness. .. In this mill, as in the other shops, most men finish their work early in the afternoon and there is semi-idleness through much of the day. 1

The auto-tag shop in the penitentiary at Walla Walla, Washington, employed one hundred men for six months to make 900,I68 license plates, while a hundred men at Jackson, Michigan, made $2,903,666$ plates in four and a half months. A hundred men in the tag shop of the Pennsylvania Western Penitentiary required nine months to make 3,200,000 plates - a daily output of 13,675 as compared with 24,8I 7 for Michigan and 5,770 for Washington. New York's prison tag shop achieved a daily output of 15,385 in the same year, 1929 - again with a working force of one hundred. ${ }^{2}$ Analyzing the above production figures, it took four men at Walla Walla and nearly two men at Western Penitentiary to do the work

1 P. 166.

2 Prison Industries, p. 106.

a.P.w. -3 
of one man at Jackson. Assuming that the Michigan shop is normally efficient, half the Pennsylvania men and three fourths of the Washington men belong, rightly, on the idle list. These figures indicate perhaps a possible difference in the manufacturing process and equipment, but the apparent differences in labor efficiency are largely due to overassignment necessitated by lack of other employment.

- This one example of tag shops - a favorite prison industry nowadays - shows how cautiously work-sheet pictures of employment should be accepted. It is of course not fair to conclude that all prison industries are as badly overmanned as the Walla Walla tag shop, but, on the other hand, some are more so (e.g., the Folsom stone quarry ${ }^{1}$ and the Colorado maintenance details mentioned above).

If we desire some general idea of the amount of overassignment in our prisons, available data afford the basis for an inexact but suggestive calculation. To be conservative and allow for possible differences in quality of production and type of equipment, we may take the overassignment of the Pennsylvania tag shop (not the Washington one) as typical of state-managed industries and maintenance jobs in prisons the country over. Anticipating what we have to say in Chapter IV, an analysis of the Handbook

11929 Handbook, p. 153. 
work sheets shows 34,69 I prisoners employed on maintenance and institutional jobs and $4 \mathrm{I}, 863$ in state-managed shops, which together is $76,554 .^{1}$ Now since output per man in the Michigan tag shop is I.8 times that in the Pennsylvania shop, it follows that on this basis about 76,500 men are employed at work which 42,500 could easily handle, and, were normal labor forces maintained, the actual number idle would be not 5,400 (5,396 as shown in Table III), but approximately 34,400 , or 34 per cent of the total penal population. We are assuming that the relatively small number $($ I 3,570$)$ employed by private contractors and the even smaller group $(9,820)$ employed on public roads and buildings are all really at work, since a contractor (whether his agreement be on a piecework or per diem basis) is not going to pay for idling, and since men are not sent to construction camps to loaf. The residue of 2,393 prisoners not classified as to type of job has also been left out of account in this rough estimate of overassignment.

Table III, then, based on figures given in the I929 Handbook, indicates that 58 per cent of our adult state and Federal prisoners were productively employed in 1928, that 29 per cent had institutional jobs, and that 5 per cent were idle. But on the basis of the overassignment known to exist in many if not most penal institutions,

${ }^{1}$ Cf. Table X. 
we estimate (still assuming the degree of overassignment to be 1.8 above normal assignment) that it would be more nearly correct to say that 34 per cent were idle in fact if not in name, that there was enough work to keep 16 per cent really employed at institutional jobs, and 42 per cent really employed in productive lines. It is well to recall here that southern institutions employed but I 5 per cent of their inmates at maintenance work in 1928.

After studying prison conditions all over the country, Frank Tannenbaum estimated that about a third of our prisoners were idle in $1922,{ }^{1}$ while Governor Emmerson of Illinois, speaking at the I930 Governors' Conference, commented as follows on the prisons of his own and other states:

Many ... are in idleness in our prisons and many are in idleness in your prisons as I go through them, and I have been through many in the United States. I don't believe you are employing 75 per cent of your men.

You may talk about employing them, but my experience and observation ... [are] that if you get four hours' labor out of the average prisoner in an institution, you are getting the maximum. ${ }^{2}$

The situation is not so much that of jobs waiting to be done by listless men as of listless men waiting for something to occupy their attention as well as their time. When really full-sized

1 Wall Shadows (New York, 1922), p. Is2.

2 United States Daily, V (Supplement, July 14, 1930), 23. 
jobs are given them, prisoners will exert themselves as vigorously as ordinary workmen.

To recapitulate: While complete idleness may not be widespread in state and Federal prisons, penitentiaries, and adult reformatories, semiidleness is prevalent, although its exact extent is difficult to judge accurately. Sixty-one per cent of the prisoners in IOI such institutions were said to be productively employed in 1923, 50 per cent in 67 institutions were so listed in 1926, and 58 per cent in 99 institutions were similarly classed in 1928; 6 per cent were admittedly idle in 1923 and 5 per cent in 1928. Thus on the basis of the most recent comprehensive figures obtainable, only something over half of all adult long-term prisoners in this country are even reported to be "productively employed," and what this phrase may mean we have attempted to point out. If our estimate of overassignment has any value whateverand the supplementary evidence sustains it the productive work now carried on could be handled by about two fifths of the total number of prisoners working as free men would normally work on the same jobs. A condition as bad, if not worse, is undoubtedly to be found in the maintenance details (which are always the first to be overmanned), so that the actual number of idle and virtually idle prisoners probably includes 30 or 35 per cent of the total prison 
population. Furthermore, the difficulties of the whole prison employment situation are aggravated daily by a steady increase in the number of commitments, an increase noted in all parts of the country and in almost every state. In the opinion of Mr. A. H. MacCormick, the saturation point in employment was reached in $1927-28$, and all population increases since then have simply "swelled the idle and semi-idle lists."1

IdLENESS in Institutions For Misdemeanants

Statistics on the employment of prisoners in county and municipal jails, workhouses, and houses of correction - institutions for misdemeanants - are of the most meager and fugitive sort. The Federal Government has no information on the subject later than that published in IgI4 in Senate Document No. $494,{ }^{2}$ which contains data on prison employment gathered by the Bureau of Labor Statistics through correspondence. Returns from 123 county and municipal penal institutions in seventeen states and the District of Columbia are included. Seventytwo of these local establishments are road camps, where, naturally, all would be at work. The total number of prisoners reported to be productively employed, on an average, was 17,152 ;

${ }^{1}$ Letter dated July 10, 1931. Mr. MacCormick, co-author of the 1920 Handbook, is now Assistant Director of the United States Bureau of Prisons. For data on population increases, cf. annual census reports beginning with Prisoners: 1920.

${ }^{2}$ Federal and State Laws Relating to Conoict Labor, pp. I0-20. 
the total number imprisoned is not given, hence we are unable to state the percentage employed. The insufficiency of these data is even more evident when we recall that the number of local institutions in the country is variously estimated at 3,500 to 4,000 .

1. Data for Eighteen States (Obtained by Questionnaire). For current information, one must depend on chance comments hidden away in the publications of state supervisory boards, and on the reports of isolated fact-finding committees and individual investigations. Hoping to obtain comprehensive information of a worthwhile sort, a questionnaire ${ }^{1}$ was sent to every state, usually to the Department of Public Welfare or to some similar public agency supposedly exercising supervisory control. The first two questions concerned the average population of all county jails, workhouses, and houses of correction, combined, and the number of prisoners under sentence and awaiting trial. The other queries concerned types of work, length of working day, disposal of products, and wages. Many of the replies stated that the desired facts were not available; others failed to cover all points or did not answer the questions precisely as formulated; in yet other cases we received printed departmental reports containing more or less information on the subject of our query.

${ }^{1}$ Cf. Appendix III. 
The following summary is indicative of our success in securing any data whatever:

No reply ${ }^{1} \ldots \ldots \ldots \ldots \ldots \ldots \ldots 6$

No data on hand $2 \ldots \ldots \ldots \ldots 22$

Data in preparation ${ }^{3} \ldots \ldots \ldots, 2$

Data sent $\ldots . \ldots \ldots \ldots \ldots$ I 8

Total...................... $\frac{42}{48}$

The doubtful value of the returns is selfevident. Furthermore, several of the eighteen states replying did not possess truly reliable data as a basis for their answers, which consequently are made up of estimates, in part. We have nevertheless attempted to tabulate the results and to analyze the findings, as some few facts of importance do appear. (See Table V.)

Only eighteen states, the District of Columbia (Jail and Workhouse,) New York City, and Detroit (House of Correction) are included. Because of differences in type of statistics reported, the Milwaukee County House of Correction is listed separately from the Wisconsin jails, making twenty-two major divisions or districts in the

\footnotetext{
1 Arkansas, Louisiana, Mississippi, Montana, North Dakota, Virginia,

2 Arizona, Colorado, Delaware, Florida, Illinois, Iowa, Kansas, Kentucky, Maine, Michigan, Minnesota, Nevada, New Mexico, Oregon, South Carolina, South Dakota, Texas, Utah, Vermont, Washington, West Virginia, Wyoming. Michigan is included in this group because the State Department of Welfare could furnish no information on local institutions, although the Detroit House of Correction has independently supplied data which appear in Table V.

3 California, Nebraska.

- Alabama, Connecticut, Georgia, Idaho, Indiana, Maryland, Massachusetts, Missouri, New Hampshire, New Jersey, New York, North Carolina, Ohio, Oklahoma, Pennsylvania, Rhode Island, Tennessee, Wisconsin.
} 

tabulation. ${ }^{1}$ It is not even safe to assume that all the important cities in the eighteen states are represented here, because state departments are not always able to secure complete statistical returns from municipalities. On the other hand, the Detroit House of Correction is included in the table, although we have no data for the rest of Michigan. Hence the most obvious comment to be made about this picture of local prison employment is that twenty-two states know nothing about the matter, while the figures for eighteen others are sadly incomplete and very difficult to compare because not uniformly compiled.

Of the twenty-two districts here shown, ten (Connecticut, District of Columbia, Indiana, Detroit, New Jersey, New York City, North Carolina, Ohio, Tennessee, Milwaukee) have computed average figures, although in the case of Indiana the average is for the State Farm only, not the jails. ${ }^{2}$ For the Indiana jails, as for the county camps of Georgia, the state farms of Alabama, ${ }^{3}$ and the jails of seven other states (Idaho, Maryland, Massachusetts, New Hamp-

1 The Detroit and Milwaukee County Houses of Correction both receive some felony prisoners, but no unconvicted prisoners; they therefore do not include all the prisoners, tried and untried, of their respective cities.

${ }^{2}$ The Indiana State Farm is included here because it receives misdemeanants chiefly, and thus reduces the state's jail population considerably.

${ }^{3}$ Sixty-four out of sixty-seven Alabama counties now turn their sentenced prisoners over to the State Board of Administration, which employs most of them on state prison farms. 
shire, New York, Pennsylvania, Rhode Island), we have not the average population but the actual number present on a given date ${ }^{1}$ while for the jails of Alabama, Georgia, Missouri, Oklahoma, and Wisconsin we have still another class of statistics - the total number committed or confined $^{2}$ during the year.

It is of course impossible to add such different kinds of figures together. To show the number of misdemeanants in prison, the best we can do is to combine the average totals with the totals for a given date, leaving commitments entirely aside and thus omitting Alabama and Georgia partially, and Missouri, Oklahoma, and Wisconsin entirely. This gives us, at the foot of the column labeled "Total Population," an approximate average of 47,869 , while total commitments in two states plus the total confined in the jails of Alabama, Georgia, and Oklahoma during one year are shown in the next column I60,840. These differences and discrepancies defeat the possibility of any statistical analysis worth the name, but a study of what facts we have is nevertheless illuminating.

Before considering the question of employment in jails and other institutions for misdemeanants,

\footnotetext{
"When the word "average" appears on the table under the figure indicating total population, all the other figures for the district in question should be read as average; similarly, when the word "actual" appears with the total population figures, the remaining data are also for the given date only.

Not, of course, identical.
} 
it is first necessary to separate the prisoners under sentence from those awaiting trial, those held as witnesses, and others temporarily detained. The United States Constitution makes slavery or forced labor illegal except for those persons convicted of crime; hence only those jail inmates under sentence may be forced to work. We need, then, to know how many of our total of 47,869 county or municipal prisoners are under sentence. Returns are even less complete on this point. Sixty-two per cent, or 29,625 , of those imprisoned are reported to be under sentence; but only 24 per cent $($ I, 528$)$ are listed as awaiting trial, etc., which leaves some I4 per cent of the total unaccounted for.

However, here are at least 29,625 persons sentenced to terms of imprisonment varying ordinarily from a few days to a year. How many of them are at work? To the best of our knowledge, 19,363 is the total number employed in the county and municipal prisons for which we have average or actual figures. This is 65 per cent of those under sentence and 40 per cent of the total misdemeanant penal population $(47,869)$ as approximately given for thirteen states, the Alabama state prison farms, Georgia county road camps, the District of Columbia, New York City, Detroit, and Milwaukee. According to the returns, the given number employed represents a minimum in five cases and exact figures 


\section{0 SHOULD PRISONERS WORK?}

are lacking for the Indiana State Farm, which manages to keep most of its men occupied.

When short-term prisoners do have work either thrust or bestowed upon them, as the case may be, what kind of jobs do they get? In the questionnaire we endeavored to differentiate between productive and nonproductive employment and to ascertain the numbers of those employed at maintenance work, road work, farm work, industrial work by hand and with machines. No numerical returns worth summarizing were received for these items; the state authorities in most cases were unable to give figures concerning work distribution. The best they could usually do was to tell us that most of those employed were assigned to maintenance jobs or road work, for example; or else we received a list of the various occupations known to be available. All these bits of information, no matter how fragmentary, are included in the table; if figures were obtainable, they are listed; if not, the principal occupations are mentioned or indicated: thus a check mark in the column headed "Farm Work" opposite the entry "Massachusetts" means that farming is one of the occupations to which at least a few prisoners are assigned in that state.

The majority of those employed are probably at "maintenance work" - not work in any true sense at all. Farm work and hand industrial 
work come next in importance, although it is impossible to give exact figures for more than one or two states. Road work appears from these figures to be a minor occupation for county prisoners in this particular group of states, except in Tennessee, Georgia, and North Carolina, where the majority are so employed. ${ }^{1}$

County road camps workitheir men hard and long: ten hours in North Carolina, and in Georgia from sunrise to sunset, which in summer means fourteen hours. Where farm or industrial work is developed, the length of the working day varies. Two states report an eight-hour day, and Tennessee and the District of Columbia report a "full day." In Massachusetts all those who work are busy seven hours a day, but only 269 out of 2,I74 are employed. Ohio reports a four-hour day. In Pennsylvania the working day varies from four to eight hours; in New Jersey it ranges from three to eight; in New York it is anywhere from one to eight and a half, and for most New York City prisoners it is

${ }^{1}$ Since July I, 193r, the counties of North Carolina no longer have authority to work prisoners upon the roads, but all misdemeanants sentenced to road work must be given into the custody of the State Highway Commission, which is authorized to build district prison camps and take over and maintain as many of the present county camps as it needs for the construction and upkeep of the county and state road systems. Counties or municipalities operating prison farms may retain enough prisoners for this work, and no prisoner sentenced to less than sixty days shall be committed to a state highway camp. This sweeping and important change in administration is part of the new State Road Law by which "all public roads in the several counties" are put under control of the State Highway Commission. Cf. State Road Law (Senate Bill No. 338, Session I93I), sec. 7, 26, 28-30, 32. 
but one or two hours ${ }^{1}$ - in fact, the city Commissioner of Correction is quoted as saying that "in New York City and State prisons the average prisoner works only one hour a day." 2 When maintenance jobs are the only thing available, as in the Georgia jails and in Maryland, this merely amounts to cleaning up in cells and corridors, and anyone acquainted with the general run of jails or with accurate descriptions of them $^{3}$ will realize that in most cases "maintenance work" means little or nothing.

Such being the case, it means almost as little to say that a total of 19,363 prisoners are " $\mathrm{em}$ ployed," when we are unable to separate productive and nonproductive employment. They may represent 65 per cent of all the sentenced misdemeanants listed, but at least 4,I 85 of them (Ohio) are employed only four hours a day and a large number - certainly more than the $3,84 \mathrm{I}$ so classified - have for employment only the picayune tasks which serve to keep their respective jails in none too clean condition. The Inspector of the Milwaukee County House of Correction tells us that he is forced to assign three, four, and five men to jobs requiring only one. Thus our 65 per cent melts away in view of overassignment, short hours, and the pre-

\footnotetext{
${ }^{1}$ Letter from Joseph F. Fishman, Deputy Commissioner, city Department of Correction; August 18, I930.

2 R. C. Patterson, New York Times, June 28, 1930.

3 Such as Joseph F. Fishman's Crucibles of Crime (New York, I923).
} 
ponderance of maintenance work. It is difficult to give a satisfactory estimate of the number of misdemeanant prisoners honestly employed. If we add together only those definitely reported to be at work seven hours or more each day, we get 9,872 , which is 33 per cent of the total under sentence, but even so we are unable to separate productive and nonproductive jobs within this group. From what we ourselves have seen in various jails, we are willing to hazard the conclusion that not 20 per cent of the sentenced prisoners in the institutions represented by Column 3 are productively employed, in any true sense of the word, for more than a few hours a day. In addition, of the 160,840 committed or confined to the jails of five states (Column 4), 10,307 are reported as sentenced and only 968 as employed; Missouri reports "very few" employed and Alabama and Oklahoma say that none of their jail prisoners are working.

Our picture of the situation is corroborated for New York State by John S. Kennedy of the State Commission of Correction:

Idleness is the curse of the jails and, despite all that we can do, thousands of prisoners lie idle each year, subject to all the evils recounted. . . . 1

2. Jail Employment in the Rest of the Country. And what of the twenty-two states whose welfare

" "The Jail Situation in New York State," in The County Fail (leaflet of the National Committee on Prisons and Prison Labor, 1929), pp. I8-I9. 


\section{SHOULD PRISONERS WORK?}

and correctional departments reported to us that they had no statistics whatever on the population of local institutions? What of employment in these unsupervised jails, workhouses, etc., and in the local institutions of the six states which did not reply to our questions?

One large and important local institution in Michigan, the Detroit House of Correction, is represented on our table independently, and data concerning it have already been incorporated in the discussion. The Division of Problems of Delinquency of the Michigan State Federation of Women's Clubs carried out a survey of county jails in 1926, and club members visited fifty-four institutions in fifty counties. They found that only four counties worked their prisoners systematically: Oakland County had some-not all - of its men busy making cement blocks, and three other counties used prisoners for road work. ${ }^{1}$

The secretary of the Nevada Board of Pardons, while unable to furnish exact figures, since the state law makes no provision for obtaining such data, informs us that there are seventeen county jails in the state, with populations varying from zero to perhaps forty; these prisoners "are all short-term offenders and no effort is made to look into their employment while confined."2

\footnotetext{
1 Julia K. Jaffray, The Michigan Fails: a Report on a Survey of the County Fails in the State of Michigan, made by the Division of Problems of Delinquency, Michigan State Federation of Women's Clubs. MS copy, p. 3 .

2 Letter dated September 12, 1930.
} 
Delaware, like Rhode Island, has in the New Castle County Workhouse an institution which combines the functions of state prison and county jail. It receives long-term state prisoners, shortterm county prisoners, and prisoners held for trial. Figures for the Workhouse are included in Table III, along with those for state penal institutions. However, we may mention here that the average sentenced population for the year ending November 30, 1929, was 595 and of these, 560 were employed, on the average. ${ }^{1}$ As about 30 per cent of the sentenced population consists of county and city prisoners, ${ }^{2}$ most of the misdemeanants evidently are employed. For institutions in the other two Delaware counties we have no information whatever.

We have reason to believe that sentenced county prisoners in Florida are usually employed on the roads. In 1928 there were forty county road camps and one leased camp, housing in all I,58I men. ${ }^{3}$ One of the state prison inspectors reported in January, I929, that in the county camps he had found convicts "mentally and physically unfit to perform labor of any kind."4 Whether or not the figure $1,58 \mathrm{I}$ includes such incapacitated prisoners we cannot tell. We have

1 Memorandum from Warden Elmer J. Leach, inclosed in letter from Secretary of State Board of Charities, October 20, 1930.

Letter from Warden Leach, October 29, 1930.

Ig29 Handbook, p. 234.

- Department of Agriculture, Prison Division, 20th Biennial Report (1927-28), p. 9 .

-P.T. -4 


\section{SHOULD PRISONERS WORK?}

no means of knowing the total number of sentenced county prisoners in the state, or the number of those awaiting trial in county jails. The Dade County Jail in Miami keeps only prisoners detained for trial; sentenced prisoners go to the county stockade outside the city and do road work. The stockade, which the author visited in February, I93 I, houses its men in a well-built concrete dormitory, constructed by prisoners, and some women are also held there to do scrubbing, sewing, and laundering.

We know that the counties of South Carolina retain under their control most sentenced prisoners, whether felons or misdemeanants, in order to work them on the roads; as a rule only poor physical specimens reach the penitentiary. ${ }^{1}$ Therefore we believe that a majority of the prisoners under county supervision - which means a majority of the prisoners in the state are at work.

In Virginia all misdemeanants found to be mentally defective must be committed to the State Farm, where they are supported by the county fees which would go to the sheriffs if the prisoners were allowed to remain in the various jails. The state is planning to establish another farm for misdemeanants exclusively, thus reducing the idle jail population still further.

\footnotetext{
1 rg29 Handbook, p. 882; South Carolina Penitentiary, Annual Report (1929), pp. 4-5.
} 
This still leaves seventeen states which admittedly know nothing about employment in their jails, and five which have not replied at all. Joseph F. Fishman, whose former position as Federal inspector of prisons gave him an exceptional knowledge of jail conditions, included idleness among the outstanding characteristics of American jails. In I923 he published examples, taken from coast to coast and border to border, of jails where evil conditions were rampant. ${ }^{1}$ Clean, decently maintained jails were the exception the country over, and likewise jails where idleness was not one of the aggravations. He mentions lack of work specifically in speaking of New York, New Hampshire, Pennsylvania, Michigan, Texas, Illinois, and Kansas. The first four have already been discussed here in the light of more recent information. The last three belong among the states which reported to us that they had no data about their jails. There is evidence pointing to the extensive use of county prisoners on the roads in Texas, ${ }^{2}$ so that we do not know how widely Mr. Fishman's accusation of idleness is applicable in that state. But we have been able to discover no indications that employment conditions in the jails of Illinois and Kansas have improved since 1923, which

${ }^{1}$ Crucibles of Crime, pp. 14, 135, 272.

2 Federal and State Laws Relating to Conoict Labor, p. I9; Ernest Booth, "A Texas Chain-gang," American Mercury, XII (November I927), 306-I5. 
means that the majority if not all of the persons confined in the local penal institutions of these two large and populous states are, in all probability, completely idle. Idleness is implied in Fishman's accounts of jails in one state after another, as he describes prisoners "seated on boxes, with their feet on other boxes," to keep out of water on the floor (Grafton, West Virginia) $;^{1}$ prisoners left entirely to their own devices, without supervision from jailer or deputy (Kentucky) ${ }^{2}$ jails where clothing and bed linen were rarely if ever washed and cells were too dark for work or reading (Alabama, Florida, Arizona).$^{3}$

That conditions had not materially altered in many places five years later is shown by the testimony offered a House Committee on. Federal penal problems in January, 1929." Joseph W. Sanford of the United States Bureau of Efficiency inspected a number of local institutions which received Federal prisoners. He told the committee about one Kentucky jail lighted by frosted-glass windows the size of a transom, with some of the cells thirty-four feet away from any such aperture. In Lucas County, Ohio, he saw another dark jail, run by a kangaroo court: ${ }^{5}$

1 Crucibles of Crime, p. 79.

2 Ibid., p. 57.

Ibid., pp. 42, 83, 86.

- Federal Penal and Reformatory Institutions, pp. $116 \mathrm{ff}$.

- The kangaroo court is a rough-and-ready, usually vicious form of inmate self-government, subject to serious abuses and always indicative of poor administration on the part of officials. 
The cells were littered, the bull pen dark and dirty. The men were sitting on blankets or lying on them on the floor. In the end where a better light was available, a poker game was in progress. 1

In the women's department were a number of Federal prisoners. ... In these quarters with Federal prisoners . . was a small girl about 14 or 15 years of age, who was being held there for the juvenile court. She was the only prisoner working. ${ }^{2}$

In the cell block where trusties were quartered, a big crap game was going on. About fifteen trusties and two or three men apparently from the outside were in the game... The guard explained the crap game, saying "the boys had to have something to do."

Another Ohio jail had no windows except skylights, and on the first floor Mr. Sanford found it "impossible to see more than two feet from the door." (Yet on our chart Ohio has a larger number employed than the total under sentence, a fact which combined with this testimony of conditions in 1928 indicates that much of the employment reported to the Department of Public Welfare is nominal.)

Obviously, inside work is impossible under such circumstances, yet Mr. Sanford "selected these jails as showing in many respects the conditions in practically all of the jails visited."

As for prisoner employment in the better maintained places, "Federal prisoners were found

\footnotetext{
1 Federal Penal and Reformatory Institutions, p. 118.

Ibid., p. IIg.

Ibid., p. I 20.

Ibid., p. 124 .

Ibid., p. I25.
} 
holding jobs as bakers, stewards, laundrymen, and as hospital attendants." 1 Mr. Sanford mentions strictly industrial work in only two places, both in Massachusetts. Jail employment of some kind is implied in his report on Maine. It must be remembered that his investigations were not comprehensive, and were concerned only with jails boarding Federal prisoners in I928. He touched Maine, Massachusetts, Rhode Island, New York, Pennsylvania, New Jersey, Ohio, Kentucky, and Michigan. The significance of his testimony lies in the fact that for so many localities it corroborates Fishman's reports of five and ten years before. J. V. Bennett, in a written report concerning Federal penal problems, made for the Bureau of Efficiency and dated March 15, I928, declares that "almost without exception there is no attempt to provide work for the sentenced man in jail during the period of his confinement." 2 This again applies specifically to jails receiving Federal prisoners, but such jails are above rather than below the average.

3. The Picture as a Whole. From these varied sources of information, then, we get testimony pointing to just one conclusion: the great majority of misdemeanant prisoners under sentence

1 Federal Penal and Reformatory Institutions' p. 128.

2 "The Federal Penal and Correctional Problem," Ibid., Appendix I, p. 192. Mr. Bennett is now Assistant Director (in charge of industries) of the U. S. Bureau of Prisons. 
are idle. In the eighteen states covered by our questionnaire (Alabama, Connecticut, Georgia, Idaho, Indiana, Maryland, Massachusetts, Missouri, New Hampshire, New Jersey, New York, North Carolina, Ohio, Oklahoma, Pennsylvania, Rhode Island, Tennessee, Wisconsin), in the District of Columbia and in Detroit, 50 or 60 per cent of the sentenced misdemeanants are certainly idle; in seven other states (Arizona, Illinois, Kansas, Kentucky, Michigan, Nevada, West Virginia), the majority are idle. In Maine, some prisoners appear to be employed, but how many we do not know; in Delaware, one of three counties succeeds in employing its sentenced prisoners; in Florida and South Carolina, most sentenced misdemeanants appear to be at work on the roads, and in Texas some are similarly employed. In Virginia, misdemeanants at the state farm are employed, but those remaining in jails are idle. Two states (California and Nebraska) are now engaged in collecting data on the subject. This leaves fifteen states (Arkansas, Colorado, Iowa, Louisiana, Minnesota, Mississippi, Montana, New Mexico, North Dakota, Oregon, South Dakota, Utah, Vermont, Washington, Wyoming) for which no specific information is available. Knowing the general characteristics of jails, we cannot assume that any large proportion of the sentenced jail prisoners in these states is employed. Unsentenced local 


\section{SHOULD PRISONERS WORK?}

prisoners are rarely given employment. Taking the country as a whole, we feel justified in concluding that at least 75 per cent of all prisoners (sentenced and unsentenced) in institutions for misdemeanants are idle.

Plainly, the problem of providing adequate labor is even further from solution in the institution for short-term prisoners than in the state prison, penitentiary, or adult reformatory. Yet, as has been often pointed out, the number of commitments to short-term institutions far exceeds the number sent to institutions for the more serious offenders, and the jail handles not only those committed to it under sentence, but many thousands awaiting trial. The distribution of commitments for the first six months of 1923 (the latest period for which we have information) shows this situation graphically, as far as sentenced prisoners are concerned. ${ }^{1}$ To institutions for misdemeanants were sent 86.8 per cent of all convicted prisoners. (See Table VI.)

Thus we see that, in spite of all the good reasons advanced in Chapter I for the employment of prisoners, a tremendous amount of idleness exists today in the prisons of the United States. Undoubtedly there is less work in institutions for misdemeanants than in those for long-term offenders. Of course the longer an individual loafs, the more detrimental are the

1 Prisoners: 1923, p. 22. 
effects of loafing, but we should note that those prisoners exposed to idleness for short intervals are far more numerous than those who must endure it for a long period. It would be hard, therefore, to measure and to compare the social harm that flows from existing idleness in the two groups of institutions. Certain it is that in each case the damage is great and must be regarded as a very serious defect in the management of our penal and correctional institutions.

\section{TABLE VI}

Prison Commitments in the United States, January I to JUNE 30, 1923

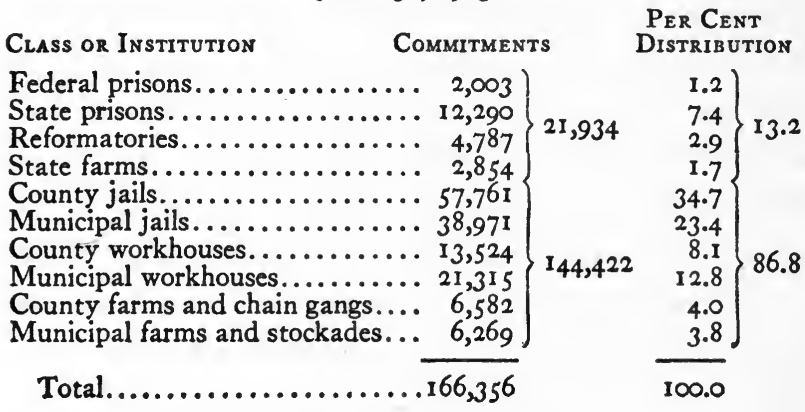




\section{THE CAUSES OF UNEMPLOY- MENT IN PRISONS}

There are two main reasons for the unemployment of prisoners - poor management and the competition of prison-made goods with those produced by free labor. It is difficult to disentangle these two factors, yet we shall attempt to do so in order that the obstacles to the proper employment of prisoners may be fully appreciated.

Poor Management in Its Various Forms

Poor management has several forms, not the least of which is the continued use of prison plants wholly out of date. This applies particularly to county jails, a great many of which have been and are still being built with no thought whatsoever for the employment of the inmates. Without adequate workrooms, power plants, or space for storage, it would take far more ingenuity than local authorities usually possess to set the prisoners to work. There are also institutions so small that little hope can be had for the development within them of any productive 
work. A thinly inhabited county very often cannot afford to maintain industries within the walls of its local jail nor can it keep alive a market for the few goods which may be produced. It does not pay financially to employ a foreman and other assistants to direct the work of a small and uncertain group of inmates.

A plant that might serve under one system of labor may not be satisfactory under another. To anticipate somewhat what we have to say in discussing prison labor systems, it should be pointed out that the present tendency is to compel a penal institution to employ at least a part of its population in producing goods for its own use. This means location in the country, and employment in general farming and truck raising. A prison plant located in a city and confined to a small area within a wall is obviously under a tremendous handicap, so far as prisoner employment is concerned, when compelled by law to give up even a part of its manufacturing business. In other words, the prison plant may easily become obsolete in part through legislative changes from one type of work to another.

Again anticipating what we have to say later, we wish to point out here that the tendency is away from systems of prison labor which call for little business ability on the part of public 


\section{SHOULD PRISONERS WORK?}

authorities to systems which require energetic business men as executives. To change, for example, from the lease system to the states-use system is to run the entire gamut of business ability in the employment of prisoners. The question of getting and keeping in public office men of proven business ability is a thorny one, embracing the subjects of public salaries, the absence of the profit motive, and the spoils system of appointment still unfortunately in vogue in most states. Nevertheless the belief that anyone possessed of sufficient brute force can successfully run a prison belongs in the limbo of discarded superstitions.

The inertia of government officials is also a potent factor in the prison unemployment situation. If idleness has been the condition within an institution, an incoming administration accepts this as a wholly natural state of affairs and makes little or no effort to bring about a change. So, too, when confronted with the necessity of shifting from one labor system to another, prison administrators by their lack of business acumen, daring, and ingenuity suffer in comparison with the entrepreneurs of the free business world.

Overcrowding is a potent cause of unemployment in some prisons. There seems to be a kind of creeping paralysis that affects prison managements and prevents them from getting rid of 


\section{CAUSES OF UNEMPLOYMENT}

old, inadequate, and obsolete plants. Yet such plants make idleness almost a certainty at a time when the prison population is increasing. Serious overcrowding exists in the Federal institutions and in the state prisons of New York, New Jersey, Pennsylvania, Maryland, West Virginia, Kentucky, Ohio, Michigan, Indiana, Illinois, Wisconsin, Missouri, Oklahoma, Colorado, New Mexico, California, Oregon, and Washington, and in countless jails the country over. Overcrowding in Pennsylvania penal institutions varies from 4 to 90 per cent. ${ }^{1}$ In the 1927 census of prisoners it is stated that "the excess of population over capacity in 1926 was II.7 per cent, rising to I9.I in 1927 . In 15 states only of the 39 reported in 1927 was the capacity not exceeded by the population." 2 The National Commission on Law Observance and Enforcement declares that:

The present situation is unquestionably worse than it was in 1927 and is probably worse than it has ever been, taking the country as a whole. In practice, this overcrowding means placing two prisoners in cells originally constructed for one. It also means that " in a few institutions, in addition to double-deck bunks in cells originally intended for one man, a mattress is placed on the floor of the cell for a third inmate." 3

1 Commission on Penal Institutions, Report (I93I), p. 12.

2 Prisoners in State and Federal Prisons and Reformatories: 1927 (Washington, 1931), p. 7.

- Report on Penal Institutions, Probation and Parole (Washington, 1931), p. II. 
Doubling-up and tripling-up means, in turn, that two and three men work where one was formerly employed, and that the idle list grows by leaps and bounds. A state that planned its work intelligently would not wait until its prisons were filled beyond capacity before building new ones and setting up new industries. It seems, however, that there must be the pressure of rioting by miserable men held in idleness before the average state will act.

\section{Prison Labor in Competition with Free INDUSTRY}

Considering now the second cause for unemployment in prisons, we find that outside manufacturers and labor organizations have long objected strenuously to the competition of prison products on the market. Their attitude has undoubtedly added much to the difficulty of finding work for prisoners. In the free world of business activity, competing concerns ordinarily have access to the same market for land, capital, and labor. The ability of one firm to put goods on the market at a lower price than can other firms must therefore be due to the superior ability of those who direct the first concern. However hard it may be on them, the others find nothing unfair in this, accepting as they do the idea of competitive enterprise. But free manufacturers and free labor have much to complain of when 
faced with the competition of prison-made goods. The prison plant may benefit from free land, cheap capital, and cheap labor. Competition under such conditions is of course ruinous. In the following chapter, where we discuss the various systems of prison labor, we shall point out what advantages each derives from these three factors in production, but it will be sufficient here to call attention to certain obvious facts in the general situation.

A state, county, or city government, if it finds it necessary to borrow, can procure capital at a lower rate than can a private business organization. Assuming accurate accounting, then, a prison plant that is run or provided by a governmental unit has this advantage to start with. But often the capital sunk in shops, machinery, etc., is not looked upon as an investment which must yield a return. This is especially true when the funds come from taxes instead of from public borrowing. Cheap or wholly free capital may thus give the prison plant a great advantage. Land may likewise be free, and if the prison grounds are large enough for a factory site, the chances are that no allowance for ground rent or land value is made in figuring costs.

When it comes to labor, the prison plant is in a peculiarly advantageous position. The prisoners themselves do not bargain for a wage scale as do free laborers on the outside. The state or other 


\section{0 SHOULD PRISONERS WORK?}

unit of government either hires them itself, paying what it wishes, or sells their labor to others. Affecting very materially the action of the public body which decides what wages, if any, shall be paid or what it will take in hire for these laborers is the fact that it must feed, clothe, house, and guard the prisoners whether they work or not.

Now when a penal institution supports itself wholly or in part from the profits of its labor, the people of the state are relieved of a very heavy annual tax bill. Consequently, profitable state-account industries and contracts which bring in a good return are likely to be popular with legislatures unless contrary pressure from interested groups is strong. The Minnesota State Prison at Stillwater has long been the shining example of what a state-account industry can do financially. By means of its binder twine and farm machinery plants, it has supported itself since $1917 ;^{1}$ recently it has undertaken rope making also. ${ }^{2}$

But such financial success is the exception rather than the rule, for there are not a dozen self-supporting penitentiaries in the country and most prisons not only fail to meet operating costs but require heavy annual appropriations. (Financial returns will be discussed in Chapter

1 Twenty-ffth Biennial Report (1927-1928), p. 6

2 Letter from Mr. E. R. Cass, July 1, 1931. 
VI.) The point that should be kept in mind is that if a prison can get back from the sale of the prison products something more than the additional expense involved in employing the inmates, it has profited financially. If, on the other hand, it sells the labor of the prisoners to others, any compensation that more than covers additional expense to which the institution may be put in hiring out the prisoners is just so much net gain. Competitive bidding for this labor force might be expected to produce a price that would measure the approximate worth of prison labor as compared with free labor, but competition does not function in this field as it is supposed to do, and with governmental authorities always anxious to offset the heavy cost of maintaining the prison and to get something out of the inmates, their labor is often sold for far less than $i$ ts true economic value. With a lower ingredient of labor costs, prison-made goods will appear on the market to compete with goods produced by free labor. It is therefore no wonder that free manufacturers and free labor organizations have time and again registered a protest against the sale of prison-made goods. The total volume of prison production in proportion to free production appears to be declining, but the Department of Commerce, according to its report on Prison Industries, nevertheless believes the situation is intensified today:

แ.P.w. -5 
Since the World War industry has found itself in a new position, in which the fighting ground of competition has shifted from production to distribution, and the effect of prison products on this new scene of conflict has been disturbed markets. 1

The Extent of Prison Competition

In discussing this troublesome question of competition, it would be most helpful if it were possible to make accurate comparisons of the production of various kinds of prison-made goods with the production of similar goods on the outside. Unfortunately, we encounter serious difficulties in attempting this.

The recent report of the Department of Commerce presents some interesting data on "return to state" for 82 of the 86 state and Federal institutions studied. ${ }^{2}$ The figures represent sales value in all instances except for those shops operated under contract, in which cases the amount paid the state by the contractor is reported. The total, $\$ 37,754,685$, which is wisely not given in the report itself, is therefore of no value for our purpose.

It is necessary to go back to the earlier report made by the Bureau of Labor Statistics ${ }^{3}$ to obtain more conclusive information. The total value of goods produced by 104 state and Federal institutions during the year I923 (approxi-

1 Prison Industries, p. 6.

2 Ibid., pp. 97-105.

3 Convict Labor in 1923. 
mately) is given as $\$ 76,096,960$, although many items are frankly estimated. This includes road and construction work. ${ }^{1}$ The value of goods placed on the market amounted to $\$ 44,843,355$ and state-use consumption (other than road and construction work) accounted for $\$ 13,645,225 .^{2}$ Now the total value of manufactured products turned out in 1923 by 196,000 manufacturing establishments, each producing goods to the value of $\$ 5,000$ or more, was $\$ 60,530,000,000 .^{3}$ We may say, then, that prison goods in 1923 reached a volume equal to 0.12 per cent of the total volume of manufactured goods produced in establishments doing a business of $\$ 5,000$ or more. But this statement takes no account of the value of goods made by local prisons or of the amount of road work which they did in 1923. The first item would be very small, but the second would be of considerable significance, as much road work is carried on in the South by the inmates of local prisons. Yet even with the addition of these two items the ratio of the value of prison-made goods to the value of those produced on the outside would still be verysmall, probably not more than $15 / 100$ of 1 per cent. ${ }^{4}$

\footnotetext{
1 Ibid., pp. 9-11. ${ }^{2}$ Ibid., p. I4.

3 Statistics collected by Bureau of the Census, quoted in Commerce Yearbook: 1929 (Washington, I929), I, 39.

4 The value of prison goods in 1886 was estimated at $54 / 100$ of I per cent of the value of total free production; in 1905 , at $23 / 100$ of $\mathrm{I}$ per cent. Cf. Commissioner of Labor, 2nd Annual Report (1886), p. 293, and 20th Annual Report (1905), p. 20; also Statistical Abstract (1909), p. I92.
} 


\section{SHOULD PRISONERS WORK ?}

Comparisons of the total volume of free and prison output do not, however, tell the whole story. We should discover if possible how various individual industries are affected, for conceivably prison industry may be concentrated so as to compete with certain lines seriously. But segregated figures for exactly identical lines of all free and prison goods are not to be had. Such comparisons as we have been able to make are presented in Tables VII and VIII, pages 55-57. The first contains figures which we believe to be reasonably comparable; the second, figures which are only roughly so.

One would not be justified in drawing final conclusions from either of these tables. They indicate that the competition of prison-made goods with other goods is not of great importance unless it be in the five lines of jute bagging, men's work shirts, street and road contracts, binder twine, and linen and part linen woven goods. Competition in the last item cannot be as great as it appears, inasmuch as it does not figure at all in the current protests from free producers. We must keep in mind, though, that for certain goods, such as brick and stone, there is not one general market but many local markets, and that the entry of prisonmade goods, even in a small volume, into one such market might easily upset local conditions of production. 


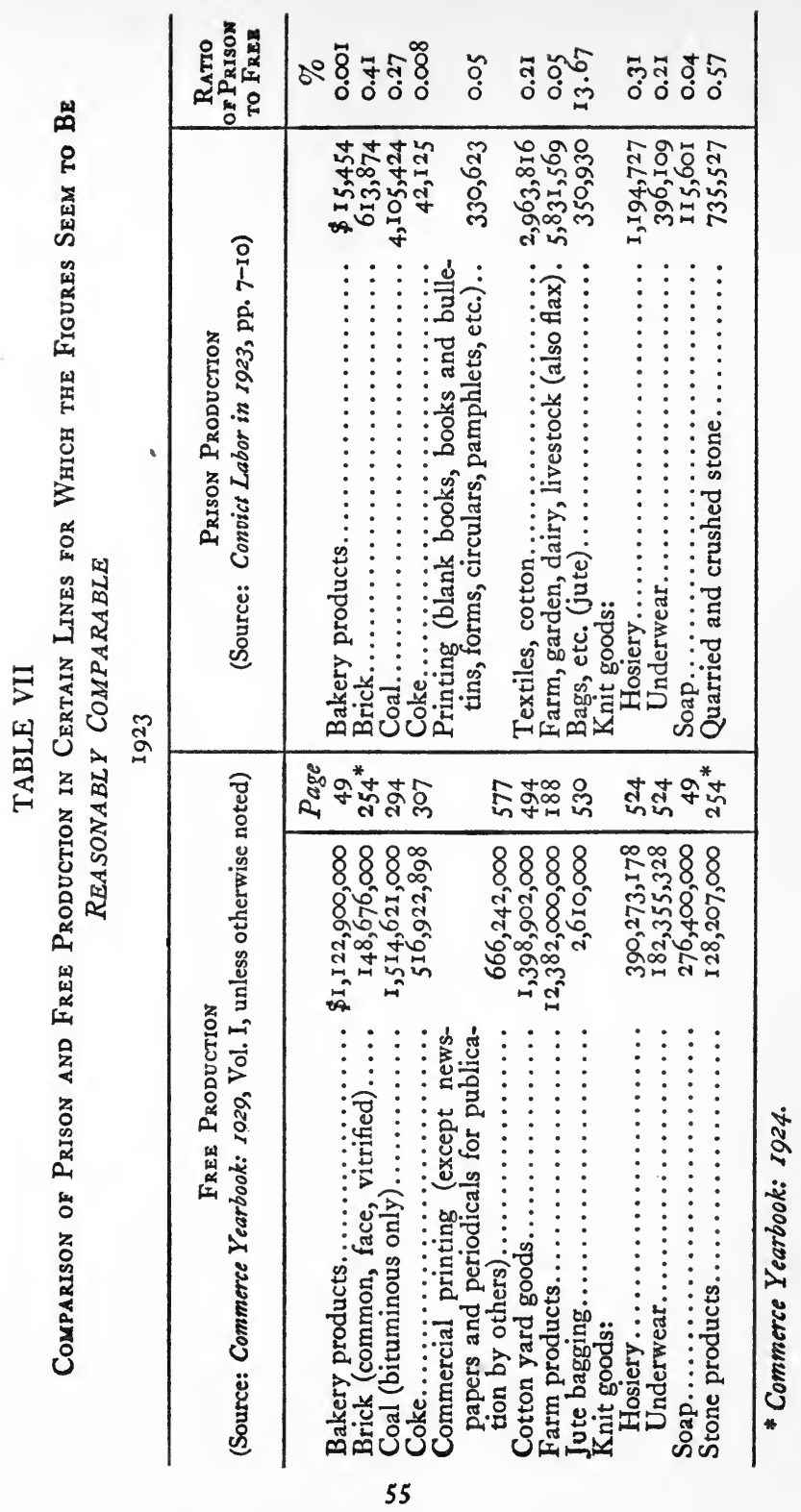




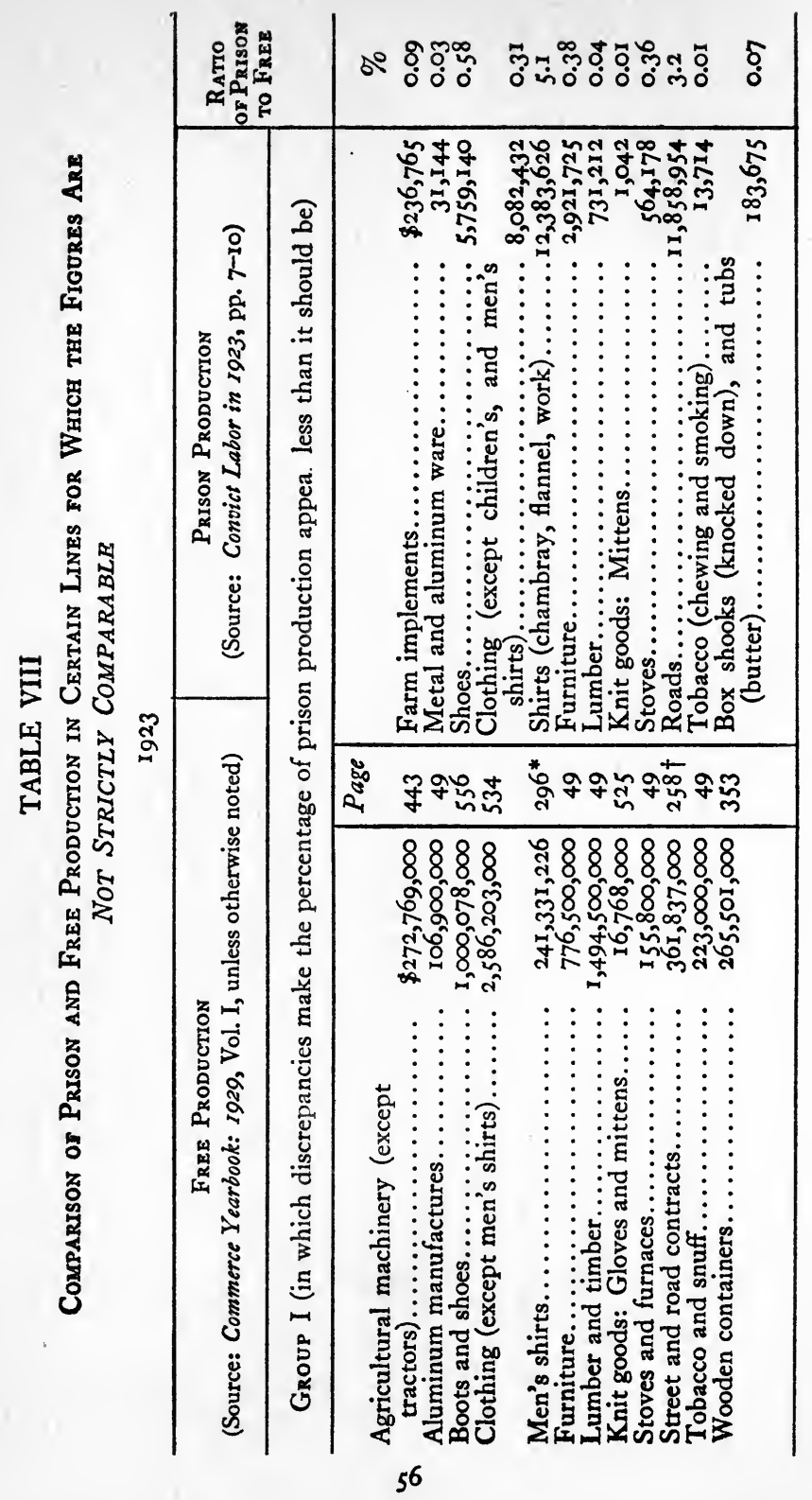




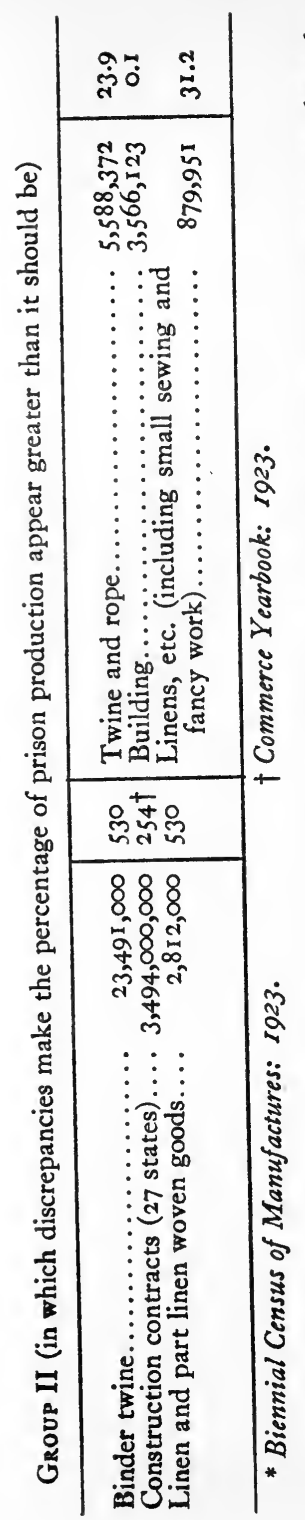

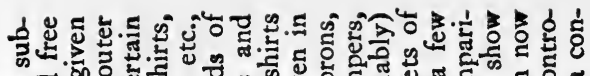

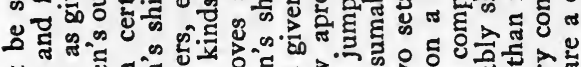
等 . o. 20

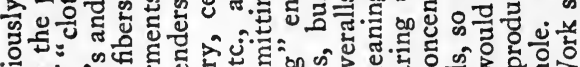

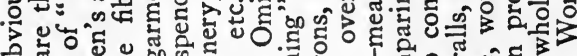

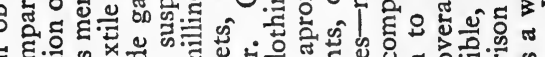

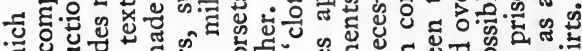

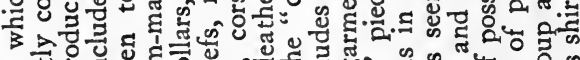

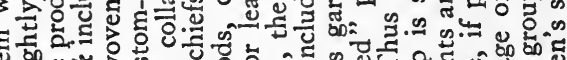

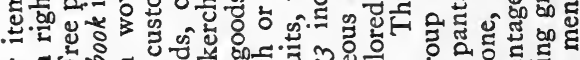
4 돤.

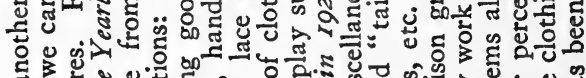

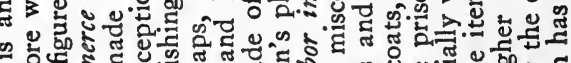
2 웅 of. 다의

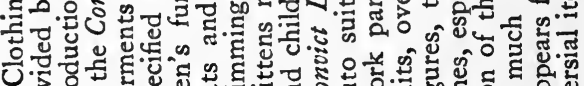

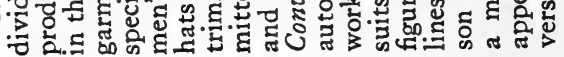

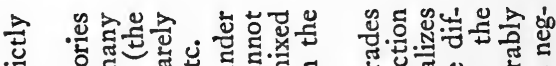

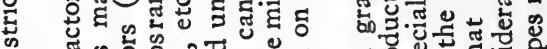

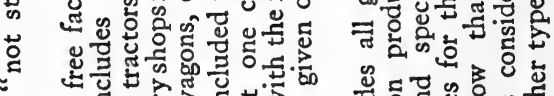
o .5 .5

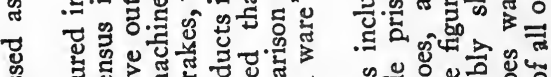
证

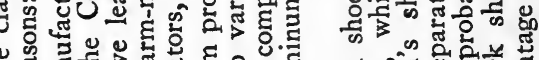

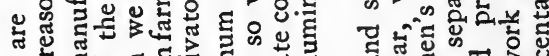

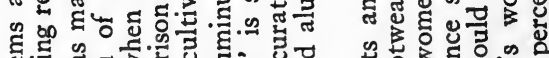

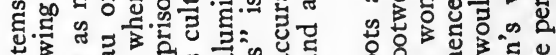

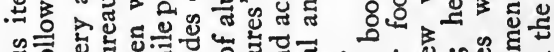
高然. .을 ग 0. F. J $1 \%$ 를 में

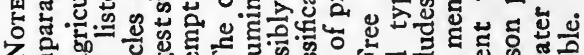

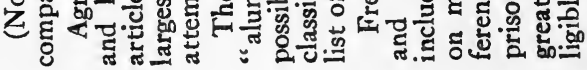




\section{SHOULD PRISONERS WORK?}

spicuous prison product, and one in which competition is said to be keenly felt. No one, however, has yet succeeded in making an authoritative comparison of free and prison production of work shirts, because men's shirts of all kinds are lumped together in the Biennial Census of Manufactures. Hence we have classed this item among those "not strictly comparable," because - although chambray and flannel shirts are included in the prison figures as well as so-called work shirts - the prison product on the whole does not touch the field of the better-grade men's shirts, and the concentration on work shirts is overwhelming - $\$ 11,756,995$ out of the total of $\$ 12,383,626$ given here for all prison-made shirts.

Furniture is placed in this "not strictly comparable" table for the same reason. There is no fine furniture of the cabinet-maker types made in prisons - nothing more pretentious than good office furniture or simple bedroom and institutional pieces with a painted or enameled finish. The bulk of the production is chairs of wood, reed, or fiber $(\$ 2,364,211$ out of the total of $\$ 2,921,725)$, and cheap chairs at that, so that in this particular class of goods the percentage of prison to free production would undoubtedly be much higher than that for the whole industry.

Lumber is not strictly comparable because the free production figures include "lumber and timber" and the prison figures include lumber only. Similarly, gloves and mittens are not separated by the Bureau of the Census, while only mittens are reported as made in prisons in 1923. Again, stoves are reported for one prison in the country, but stoves and furnaces are classed together in the free production figures. Nor are road contracts separable from street and road contracts, and the "wooden containers" classification presumably includes much more than box shooks and butter tubs. Chewing and smoking tobacco, listed among prison production items, are not separated from "tobacco and snuff" on the free production lists.

When we come to binder twine, the classification of prison products includes both twine and rope, which somewhat increases the percentage of prison production to free production of binder twine alone. The value of construction contracts given for 1923 included only 27 states, a fact which undoubtedly would make the real percentage of buildings constructed by prison labor far lower than even that shown here. The Bureau of the Census classifies linen and part linen woven goods together, but the term "linens" on the prison lists includes small sewing and fancy work.)

\section{A different approach to the question of prison} output in relation to free production is used in an analysis of production in certain lines in the state of New York, for the year ending June 30, 1929. ${ }^{1} \quad$ (Table IX.)

${ }^{1}$ Chart CPI-I3, prepared by Division of Prison Industries, State Department of Correction. 


\section{CAUSES OF UNEMPLOYMENT}

TABLE IX

Comparison of Prison and Frex Production in New York, 1929

\begin{tabular}{|c|c|c|c|c|}
\hline \multirow{3}{*}{ Activity } & \multicolumn{4}{|c|}{ Approximate Returns for Year Ending June 30,1929} \\
\hline & \multicolumn{2}{|c|}{ Value of Products } & \multicolumn{2}{|c|}{ WORKERS EMPLOYED } \\
\hline & State & $\begin{array}{c}\text { State } \\
\text { Prisons }\end{array}$ & State & Prisons* \\
\hline $\begin{array}{l}\text { Men's clothing, in- } \\
\text { cluding cloth } \\
\text { hats and caps... } \\
\text { Foundry and Ma- } \\
\text { chine shop prod- } \\
\text { ucts............. } \\
\text { Knit goods....... } \\
\text { Boots and shoes... } \\
\text { Printing and pub- } \\
\text { lish ing, book } \\
\text { and job......... } \\
\text { Furniture, includ- } \\
\text { ing chairs....... } \\
\text { Cotton goods....... } \\
\text { Woolen goods..... } \\
\text { Lumber and tim- } \\
\text { ber products..... } \\
\text { Sheet metal prod- } \\
\text { ucts............ } \\
\text { Signs and adver- } \\
\text { tising novelties.. } \\
\text { Brooms and brushes } \\
\text { Hair work......... }\end{array}$ & 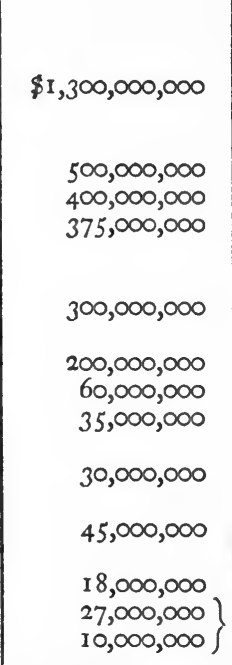 & $\begin{array}{c}\text { I 7,000 } \\
\text { I } 50,000 \\
226,000 \\
290,000 \\
18,000 \\
37,000 \\
470, \infty 00 \\
145,000\end{array}$ & 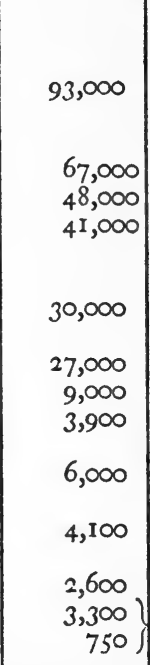 & $\begin{array}{r}30 \\
315 \\
440 \\
220 \\
55 \\
80 \\
125 \\
200\end{array}$ \\
\hline Together.......... & $\$ 3,300,000,000$ & $\$ 1,946, \infty 00$ & 335,650 & 1,950 \\
\hline $\begin{array}{l}\text { Production per } \\
\quad \text { worker.......... }\end{array}$ & $\$ 9,800$ & $\$ 1, \infty$ & $\cdots \cdots \cdots$ & ....... \\
\hline All others........ & $12,200,000, \infty 00$ & $24, \infty 00$ & $1,124,350$ & I 50 \\
\hline Totals........... & $\$ 15,500, \infty 00, \infty 00$ & $\$ 1,970, \infty 00$ & $I, 460, \infty 00$ & 2,100 \\
\hline $\begin{array}{l}\text { Production per } \\
\text { worker.......... }\end{array}$ & $\$ 10,6 \infty 0$ & $\$ 980 t$ & $\cdots \cdots \cdots$ & $\ldots \ldots$ \\
\hline
\end{tabular}

* Reflects inmates directly employed in respective activities.

$\dagger$ Should be $\$ 938$, which is the quotient of $\$ 1,970,000$ divided by 2,100 . 
This shows for the chief prison industries the value of production in the state and in the prisons, also the number of free and of prison workers employed. The source of the free production figures is not given. The production per free worker - i.e., per capita output - in certain important prison lines is found to be $\$ 9,800$ as against $\$ 1,000$ per prison worker. For all lines of activity together, the ratio is $\$ 10,600$ production per free worker against $\$ 980^{1}$ per prison worker. In 1923 the total value of $\mathrm{New}$ York prison production was but $\$ 1,789,397$ with an average of 2,395 workers, ${ }^{2}$ - or $\$ 747$ per capita. Some increase in per capita production has evidently taken place during the six years.

Assuming that all the items on the table are strictly comparable, its conclusions are justified as far as they go, but they do not tell the whole story of competition any more than do our I923 figures showing the total volume of prison production in relation to free production.

The competition of prison shops appears from the available data to be greater in a few lines than most prison officials admit, but less than trade interests claim. Without far more accurate information about specific lines of production, in prison and out, and knowledge of the markets in which prison goods are offered, it is

1 This should really be $\$ 938$, according to the figures given.

2 Conoict Labor in 1923, pp. 52-3. 
impossible to draw definite conclusions on the true extent of prison competition.

The Attitude of Union Labor

Throughout the entire nineteenth century and down to the present time the steady pressure of union labor has been applied to restrict the sale of prison-made goods and the use of prison labor on building construction; occasionally road work by prisoners has been protested against. The industries principally affected have been boots and shoes, cheap clothing, cheap furniture, brooms and brushes, iron hollow ware and stoves, harness and whips, binder twine, cooperage, hosiery, and farm machinery. As each trade became organized, there was agitation to restrict or eliminate the manufacturing of its particular product in prisons. ${ }^{1}$

As a result of trade-union activity, various types of laws governing convict labor have been enacted by state legislatures. There are general statements that prison labor is not to conflict with free labor. There are provisions for or against convict labor in certain lines. Diversification, with percentage restrictions, is sometimes made mandatory. ${ }^{2}$ Often machine work is forbidden, and the hours of work are limited.

1 E. T. Hiller, "Labor Unionism and Convict Labor," Fournal of Criminal Law and Criminology, V (1915), 851-79.

$2 \mathrm{~J}$. R. Commons and J. B. Andrews, Principles of Labor Legislation (New York, I920), p. 80. 


\section{SHOULD PRISONERS WORK?}

Sometimes the prisons are not allowed to set up any industry which is prominent in the state; thus Michigan still "forbids the teaching of a trade to convicts excepting only the manufacture of such articles as are mainly imported into the state." 1 A common example of restrictive legislation is the requirement that the goods be labeled in some way, as with the words "convict made."

Labor has had undoubted provocation. Due to short-sighted management, prison industry has at times been very heavily concentrated on a few lines. Cooperage in the Chicago market of the I880's and early I900's was virtually monopolized by the prisons, driving skilled coopers entirely out of work by forcing the closing of most of the free shops. ${ }^{2}$ Cheap iron hollow ware was and still is virtually a prison monopoly. ${ }^{3}$

The trade-union attitude was for years one of blind hostility to prison labor in general. The idea of social responsibility for the troubles of this world was as little felt by the unions as by the rest of us. Hugh Frayne, one of the broadminded labor leaders, wrote in I92I that "only within the past few years" had the

\footnotetext{
1 Principles of Labor Legislation, p. 80; cf. also Monthly Labor Review, XXVIII (March 1929), I3I.

2 Commissioner of Labor, 20th Annual Report, pp. 155-68.

${ }^{3}$ Frank J. Stockton, "The Prison-labor Policy of the Molders' Union," Fournal of Crimimal Law and Criminology, VII (May 1916), 129-30; Convict Labor in 1923, pp. 148-51.
} 
trade unions been convinced that prison shops well equipped for state use did not offer unfair competition. ${ }^{1}$

The hostile attitude of the unions has been expressed very concretely. By means of a boycott on its products, Michigan bricklayers forced the prison brick plant at Jackson to close in I925, and this is but one example of effective opposition. ${ }^{2}$

Union spokesmen today do recognize the convict's needs. They attempt to reconcile his needs with their own, and as a result advocate the state-use system enthusiastically. ${ }^{3}$ In the chapter which follows, this system will be discussed in some detail, but at this point we shall merely note that under it the goods produced in prisons are not permitted to appear in the open market but are used by the state itself, by its political subdivisions, or by public institutions. The unions believe this arrangement is least injurious to them and have gone on record time and again as being in favor of it.

1 "The States Use System," Fournal of Criminal Law and Criminology, XII (Nov. I92I), 330.

${ }_{2}^{2}$ American Year Book (1925), p. 623; ibid. (1926), p. 626.

${ }^{3}$ Road Making by Convict Labor (Bulletin No. I of the National Free Labor Association; New York, I9I3), p. 39. John Mitchell, "The Wage-Earner and the Prison Worker," Annals, XLVI (March I913), 8-16. John P. Frey, "The Trade Union Attitude towards Prison Labor," ibid., pp. 132-7. Collis Lovely, "The State-Use System," ibid., pp. 138-4I. Samuel Gompers, "Contract Prison Labor the Shame of It," American Federationist, XXVIII (June I92I), 497-500, American Federation of Labor, "Report of the Legislative Committee," ibid., XXXII (Feb. I925), I 23-4. John J. Sonsteby, remarks in American Prison Association, Proceedings (1928), p. 68. 


\section{SHOULD PRISONERS WORK?}

But we must not assume that under the stateuse system all union opposition will disappear. In New York printing and engraving are prohibited in the prisons and reformatories, even for state use, "except such printing as may be required for or used in the penal and State charitable institutions, and the reports of the State commission of prisons and the superintendent of prisons, and all printing required in their offices." 1 The American Federation of Labor has worked out a socially-minded program for state-use industries in prisons and talks about providing valuable work, training, and compensation for every prisoner, but the national program does not always control local policy. This is all too evident from a reading of the Proceedings of the 1930 national convention, ${ }^{2}$ where a delegate from the Granite Cutters' International Association of America introduced a resolution opposing the use of convict labor to quarry and cut granite for a new state office building in Madison, Wisconsin. The resolution was réferred to the Committee on Building Trades, which recommended its adoption. Whereupon followed a discussion of considerable interest, which we quote at length, in order to let labor representatives speak for themselves:

1 Consolidated Laws, sec. 176, ch. 43, quoted in Conoict Labor in 1923, p. 226.

American Federation of Labor, Report of the Proceedings of the 50th Annual Convention (1930), pp. 23, 105, 257, 376. 
Delegate Ohl, Wisconsin State Federation of Labor: I hesitate to take issue with the representatives of any international union when an effort is being made to conserve work for their membership, but we cannot consider this resolution without taking into consideration as well the position of the American Federation of Labor in regard to the state-use system. In many of the states an effort has been made to prevent prison products from going into the open market. In some respects some success has been had. In this particular instance the question arose whether the State of Wisconsin shall conform to the Hawes-Cooper Act, which is, as I understand it, after all merely an enabling act, by beginning somewhere to do some work for the state itself.

The Board of Control hit upon the plan of using some state-owned real estate upon which there were quarries to do certain work for the state institutions. We did not suggest that this be done, but they felt that a start [should] be made, inasmuch as labor insisted that no work be done in the future to be put on the open market. If this resolution is adopted you will put yourselves in the position of asking the State of Wisconsin not to put into operation the plan the American Federation of Labor has been fostering. You will not only be helping the Board of Control, which is opposed to this plan and which appeared before the committee when the Hawes-Cooper bill was up, in opposition to it - you will not only kill the plan we are sponsoring and [trying to] extend to other states, but it will make your Executive Council look ridiculous to go into Wisconsin and ask them to prevent this work being done.

We stopped the sale of monumental stone sold in the open market. We who sat in these conferences knew that some group is bound to be affected. We also knew that we were compelled to concede that prisoners, after all, must do some work. The American Federation of Labor was forced to concede that. If you adopt this resolution you are going to ask the American Federation of Labor 


\section{SHOULD PRISONERS WORK?}

to run counter to the very plan they have adopted and asked the states to put into execution.

Delegate Squib B, Granite Cutters' International Association: Delegate Ohl, in his remarks, spoke about this being an initial attempt to put into effect the policy of the Hawes-Cooper bill, and he asked what will be the effect if this protest is entered against it. I would like to ask him, I would like to ask all the delegates here, if it be the idea of those in authority in our states to build all our public buildings with convict labor, what will be the result then? It seems to me that if endorsing this resolution does involve even the reversal of policy, in the interest of the men we represent we should not hesitate to reverse the policy.

President Green: The American Federation of Labor is not in favor of public buildings being erected by convict labor. We favor the employment of convict labor for the purpose of manufacturing goods and material for state use by the state and by the political sub-divisions of the state, but we always contend that in the erection of public buildings our skilled free workmen shall be employed. I wish that the delegates may not become confused regarding our policy.

We realize that the convicts in our state institutions must be considered; we favor the employment of convicts in the manufacture of goods for state use within the state and by the political sub-divisions of the state. We secured the enactment of the Hawes-Cooper bill so that a state that had adopted a convict labor measure prohibiting the manufacture and sale of convict-made goods manufactured within the state in competition with free labor within the state, could prohibit the sale of convictmade goods within the state, manufactured by convicts in other states. ... .

In connection with the employment of convict labor we want to pursue a humane and reasonable policy, but we do not believe that goods manufactured by convict labor should be sold in the open market and convict labor used 
in competition with free labor for the purpose of reducing our American standards of living.

Delegate Ohl: The understanding is that the construction work will not be done by prison labor, it will be confined to the quarry. In answer to Brother Squibb's question I would say that it is not our idea to have the state do construction work. We want them to keep away from the work that comes under the jurisdiction of ourselves. The idea in Wisconsin is that about four hours of the time of the prisoners be devoted to education, but I don't know what Florence Curtis Hanson [of the American Federation of Teachers] would say if we put some of those prisoners on the faculty of the prison; I don't know what Joe Moreschi [of the International Hod Carriers', Building and Common Laborers' Union of America] would say if we put some of the men on state road work, and we don't know but what Fred Baer [of the International Association of Fire Fighters] would protest a prison fire department.

Delegate McDonough, Plasterers: Are you opposed to the adoption of this resolution?

Delegate Ohl: Certainly. I don't think it ought to be done that way. I would suggest that the Executive Council make further inquiry and see if they can do anything in respect to some of these things without going back on a plan they have adopted at several conventions.

Delegate McDonough: I want to say for the information of the brothers that our committee [on Building Trades] received information that the State Federation of Labor was in accord with the plan of using convict labor for cutting granite. There was nobody before the committee from the Wisconsin State Federation of Labor to deny that statement, and, personally, I believe it will not embarrass the Executive Council or the officials of this organization to prohibit the use of convict labor on buildings. I believe the resolution should be unanimously adopted by the convention.

$$
\text { -.P.w. }-6
$$


Delegate Ohl: This was not a proposal, nor was it in agreement with the Wisconsin State Federation of Labor. The Board of Control and the Wisconsin State Federation of Labor did not work out this thing to begin the system at the quarries. That was done by the Board of Control. We felt if we entered a protest in this case that protests would be made in other states.

Delegate Seuibi: I hate to take up the time of the convention discussing this matter, but it seems there is confusion in the minds of some of the delegates concerning the question. If there were buildings being constructed by convict bricklayers and carpenters and other trades, there would be a terrific outcry. According to Delegate Ohl's discussion it would be a proper thing to put a shed up alongside the building, put convict granite cutters inside of it and the idea would be all right.

The report of the committee was adopted. ${ }^{1}$

The same convention adopted a resolution urging the employment of only civilian mechanics, not prisoners, in the construction of Federal penal institutions. ${ }^{2}$ Yet if the construction of state and Federal penal institutions is not a legitimate form of state-use employment, what is? To permit prisoners to manufacture shoes and garments for state use and not to work on state buildings seems an unfair discrimination against shoe and garment workers. The gist of the matter is that the American Federation of Labor officially favors the stateuse system of prison labor but refrains from urging its consistent adoption in the face of specific opposition from affiliated unions in par-

\footnotetext{
1 Proceedings of the 5oth Annual Convention, pp. 257-8.

2 Ibid., p. 244.
} 
ticular cases. More than any other one agency, the Federation is responsible for the passage of the Hawes-Cooper Bill, which we shall discuss in the next chapter, and in every state is strongly pushing restrictive legislation whose wisdom is open to doubt. It is but fair to add, however, that the unions have shown a fine spirit of cooperation in certain states (notably New Jersey) where their help has been solicited, and later on we shall consider this along with other solutions of the problems involved in employing prisoners.

\section{The Attitude of Manufacturers}

Opposition to the competition of convict labor has by no means originated entirely with organized labor. Another interested party is the employer, the manufacturer, the man who is afraid of seeing his business ruined by constant undercutting on the part of prison-made goods. This group is far from inarticulate, and many of the laws which hamper the development of prison industries, as well as the evasions which nullify good prison laws, are due in part to the pressure exerted by manufacturing interests. ${ }^{1}$

${ }^{1}$ Cf. Commissioner of Labor, 20th Annual Report, 1905, pp. 49-50 ff.; A. M. Edwards, "Labor Legislation of Connecticut," Publications of the American Economic Association, 3rd series, VII, No. 3 (I907), 247; U. S. Department of Commerce, Bureau of Corporations, Report on Farm-Machinery Trade Associations, I9I5 (Washington, I9I5), pp. I07-10; "Establishment of Convict Labor System in Utah," Monthly Labor Reoiew, XXXIII (August I924), 176-7; Ellen C. Potter, "Penal Affairs in Pennsylvania," Prison Fournal, IV (April I924), 6; American Year Book (I 925), p. 623; Nels Anderson, " 'Stir' Slaves; the State-Use System," Outlook, CXL (I928), 542. 
The opinions of manufacturers on the subject of unfair prison competition are set forth at length in one of the bulletins of the Bureau of Labor Statistics. ${ }^{1}$ The burden of most of these complaints is that prison contractors and prison managers, by paying no wages or only nominal ones and by being able to neglect ordinary overhead costs, easily undersell the products of free labor. But, according to more than one manufacturer, the competition is felt in dull seasons only. ${ }^{2}$

Much of this storm of protest has of course been occasioned by the very real advantage which private prison contractors have been able to obtain, so that the matter takes on the appearance of a struggle between those manufacturers having prison contracts and those without. $^{3}$ In the scuffle the real welfare of the prisoner and the problem of the state's administrators count for very little, even though each is made a talking point by one of the two sides. Garment manufacturers, for example, repeat and repeat the comment that the garment trades are women's trades on the outside, and that men trained to make dresses or work shirts are unfitted to obtain jobs on release. ${ }^{4}$ This is

\footnotetext{
1 Convict Labor in r923, Part II.

Ibid., pp. 124, 163 .

${ }^{3} \mathrm{Cf}$. National Anti-convict-Contract Association, in Commissioner of Labor, 2nd Annual Report, I886, p. 366.

- Convict Labor in 1923, pp. $113,124$.
} 
largely true, and carries more weight than the statement by officials of the Eastern Broom Manufacturers and Supply Dealers Association that brooms should not be made by convicts because broom making is particularly suitable for the blind. ${ }^{1}$ (The consideration is an important one, but the value of brooms produced in the United States in 1923 was $\$ 26,262,000$, of which the blind were estimated to have produced less than 5 per cent, ${ }^{2}$ while the value of convictmade brooms and brushes for I 923 was $\$ 1,816,189,^{3}$ or not quite 7 per cent of $\$ 26,262,000$. One wonders whether the Association curtails its production in any way in order that the institutions for the blind may have more of the business.) Defenders of contract prison labor, on the other hand - usually wardens who see no other solution - argue that work is what counts and that garment making at least keeps the man productively employed. ${ }^{4}$

The binder twine manufacturers direct their bitter protests against the manufacture of cordage, insisting that it is a poor industry for prisons to take up because labor is only a small percentage of the manufacturing cost, while a large capital outlay is necessary and the seasonal

${ }^{1}$ A. F. Allison, "The Manufacturers' Viewpoint on Prison Labor," Report of Proceedings of National Conference on Reduction of Crime, p. 103 .

2 Federal Penal and Reformatory Institutions, Appendix II, p. 210.

${ }^{3}$ Convict Labor in 1923, p. 7 .

- Cf. Prison Industries, p. viii; 2929 Handbook, p. 254. 


\section{SHOULD PRISONERS WORK?}

risk is great. ${ }^{1}$ The bitterness of their letters is doubtless due to the price policy of the prisons, which undersell outside manufacturers and sometimes go so far as to guarantee that their prices will always be lower regardless of cost. ${ }^{2}$ The manufacturers consider it unfair that public taxes should be used to support an industry which (according to them) gives the farmers very little benefit through lower prices and does much to ruin the free industry:

"Many expenses," they say, "that should be directly charged by the States to the operation of their prison plants are rather uniformly overlooked, and the benefits of apparently lower prices of binder twine to farmers are derived through the imposition of greater taxes on the State as a whole."3

Like the labor unions, the manufacturers have finally come to see that prisoners should have work to do, and have likewise accepted the stateuse system as the best method of employing them. The United States Chamber of Commerce advocates the exclusive state-use system of employment, according to its spokesman, Mr. E. W. McCullough:

States which operate under the State-Use System, we believe, afford the greatest opportunity to develop a worthwhile plan of reformation and at the same time solve the present problem of prisoner made goods being

1 Convict Labor in 1923, Part II.

2 Ibid., p. 133.

IIbid., p. 132. 
dumped on the open market to demoralize the situation for goods produced by private capital and free labor. ${ }^{1}$

An example of vigorous opposition, very onesided publicity, and uncritical advocacy of state use is to be found in a trade journal devoted to the interests of the toy business; six or eight pages of a recent issue are taken up with protests against prison-made toys, protests based on the establishment of a toy factory in the Michigan State Prison." Under the title "Convict Contracts for Toys Loom as Large Threat to Toy Makers"- although no evidence is given that toys produced at the Michigan prison will be manufactured under contract - one article maintains that the proper field for prison industry lies in supplying state needs. It is obvious that toys have little if any place in state-use requirements.

But all trade opposition to the employment of prisoners does not melt away with the adoption of the state-use system any faster than does opposition from the labor ranks. The attitude of the two groups is exactly comparable: official utterances exhale a reasonable and coöperative spirit, but local action is selfish and unthinking.

"When Auburn was starting out to manufacture school desks and furniture," says Mr. H. B. Gill, "the school

\footnotetext{
1 "Manufacturing in Prisons - Some Observations of Business," American Prison Association, Proceedings (1926), p. 250.

${ }^{2}$ American Toy Manufacturer (Sept. 1930), pp. 10-1 5 .
} 


\section{SHOULD PRISONERS WORK?}

supply houses patented a new type of desk which they convinced all the superintendents and teachers they must have ... and the prison industry was severely curtailed."1

Mr. A. H. MacCormick has made much the same statement:

We understand that the ... Associated Manufacturers are friendly to the state-use system as a nation-wide organization. But what about the local manufacturers in each State who want to sell the school desk to the school department of New York, who want to sell the carts and harnesses and garbage pails to the street cleaning department of New York City, who want even to sell the shoes to the prison itself? It is their opposition which makes the state-use system exceedingly hard in any state and every prison man, I think, would agree with that. ${ }^{2}$

In the summer of 1927 the Philadelphia Board of Education delayed a contract which had been granted to the Pennsylvania Reformatory at Huntingdon for the manufacture of school furniture. The Prison fournal, commenting on the incident, says:

We are under the impression that the objection to this transaction arose from dealers and employers more than from organized labor. It is very likely that other bids for furniture supplies would go to companies operating outside of the State of Pennsylvania where union labor is not recognized. The agencies for such supplies are eloquent in objecting to goods made in prisons. ${ }^{3}$

${ }^{1}$ Testimony before New York State Crime Commission, Nov. 21, 1929, p. 1376. Mr. Gill is Superintendent of the Norfolk Prison Colony, Massachusetts.

${ }^{2}$ Report of Proceedings of National Conference on Reduction of Crime, p. I2I.

2 Vol. VII (July 1927), 21. 
The Deputy Commissioner of Correction for Massachusetts, in November, 1929, discussed before the New York State Crime Commission the adoption and development of the state-use system in Massachusetts, and said:

The only difficulties we have had came from a manufacturer of brushes and a manufacturer of mattresses, but [there have been] no difficulties whatever from the labor movement. ${ }^{1}$

Yet later on in the same talk he shows how the whole history of state-use in Massachusetts has been one long struggle to force the state and county institutions and the municipalities to purchase prison products according to the law, how manufacturers succeeded in underbidding the prison shops and did their best to take the business allotted to the prisons. Superintendent Howard B. Gill said on the same occasion that there was opposition the moment a prison shop produced enough to be a market factor-that diversification was the thing which made possible the success of the state-use system in Massachusetts. ${ }^{2}$

A good example of combined opposition to state-use industry is to be found in the reports of the Ohio Department of Public Welfare, which

1 E. C. R. Bagley, testimony before New York State Crime Commission, MS stenographic report of proceedings, November 21, 1929, p. 1332 ; as corrected in letter of August 18, I931.

2 New York State Crime Commission, MS report of proceedings, November 21, 1929, p. 1377. 


\section{SHOULD PRISONERS WORK?}

has charge of the industries in the state penal institutions and has long operated a successful brick plant at Junction City, using the labor of honor prisoners transferred from the penitentiary and the reformatory. The purchase of another plant, at Roseville, was arranged in 1924, but for three years "selfish interests ... were instrumental in enjoining the state from acquiring or paying for this plant." 1 The Attorney General made rulings which prevented the use of purchase funds and the State Board of Control withheld approval of other funds, while stockholders' suits and injunctions further delayed settlement. The editors of the 1929 Handbook state that these "selfish interests" represented both labor and manufacturing organizations, ${ }^{2}$ and the Department adds that politics were also concerned. The net result of the delay was idleness for two hundred prisoners over a period of three years, and deterioration of the property until complete rebuilding became necessary $^{3}$ at the expense of the taxpayers, of course.

"Selfish interests" may sometimes be turned to the benefit of prison industries - witness the success of the Minnesota prison twine plant, which owes its origin to the Minnesota farmer's

\footnotetext{
1 Advance Sheets: 6th Annual Report (1927), p. 26; 7th Annual Report (1928), p. 27.

P. 747.

8 Seventh Annual Report (1928), p. 27.
} 
fear of the "cordage trust" of the 90's and early I900's; the Stillwater plant was established for the express purpose of preventing a monopoly in binder twine and insuring the wheat growers a supply of twine at low prices. ${ }^{1}$ Such an enterprise was made possible by the dominance of agricultural interests in the state. It is the old story of the tariff over again - one set of producers opposed to another.

\section{Opposition From Other Quarters}

The use of prison labor for road construction is frequently recommended by representatives of the skilled industries. But now road contractors begin to grow alarmed at the prospect, and we read in the Washington (D. C.) Evening $S t a{ }^{2}$ that the Associated General Contractors have protested to the Virginia State Highway Commission against its use of prisoners in the grading work preliminary to the construction of the Lee Boulevard.

In all this hue and cry over unfair competition nothing is said about farm products. Manufacturers and labor men unite in recommending the employment of prisoners in maintenance and farm work, but were the farmers organized we should doubtless hear from them more forcibly on the subject. The governors of three farming states have spoken of the competition burden

\footnotetext{
1 Convict Labor in 1923, p. 125.

2 February 20, 1931.
} 
which the state-use system shifts to the farmer, ${ }^{1}$ while we know of two definite protests against prison farms or their products: the West Virginia Farm Bureau Federation objected strongly when the State Board of Control suggested establishing a farm at the penitentiary, to raise produce for it and other state institutions; ${ }^{2}$ and Virginia dairymen opposed the sale of milk from state prison farms to the city of Richmond. ${ }^{3}$

Mr. Paul W. Garrett summed up the whole matter of opposition very succinctly at a meeting of the New York State Crime Commission on November 22, I929:

The forces opposing prison industries were organized to combat the contract system, yet the opposition has persisted not only when the contract system was abolished (in many states) and when the state-account system was set up, but when the state-use system was set up and highly diversified. Opposing forces have been decisive factors in making the state-use system so generally futile (which it undoubtedly is) as a means of employing most or all of the prisoners all of the time, as a means of paying a substantial part of the cost of prison maintenance, and as a means of industrial training for inmates. The organized minorities may be expected to cease their opposition to prison industries about the same year that business interests oppose increases in tariff on their own products because such increases are contrary to the general welfare.4

${ }^{1}$ Christianson of Minnesota, Leslie of Indiana, Hammill of Iowa, at the 1930 Governors' Conference; cf. United States Daily, V (Supplement, July I4, I930), 21, 23.

${ }^{2}$ New York Times, December 7, 1930.

3 Governors' Conference (1925), Excerpts from Minutes (National Committee on Prisons and Prison Labor), p. 9.

MS stenographic report of proceedings, p. 1460; as corrected in letter of August I I, I93I. 


\section{IV}

\section{SYSTEMS OF EMPLOYING PRISONERS}

\section{Definitions}

Several systems of employing prisoners have been tried and are still used in this country; no one of them is superior in every respect to all the others. They are described as follows by the Bureau of Labor Statistics:

LEASE SYSTEM. Under this system the state enters into a contract with a lessee, who agrees to receive the convict, to feed, clothe, house, and guard him, to keep him at work, and to pay the state a specified amount for his labor. The state reserves the right to make rules for the care of the convict and to inspect the convict's quarters and place of work. No institution is maintained by the state other than a place of detention, where the convicts can be held until placed in the hands of the lessee and in which to confine convicts who are unable to work.

Contract system. Under this system the state feeds, clothes, houses, and guards the convict. To do this the state maintains an institution and a force of guards and other employees. A contractor engages with the state for the labor of the convicts, which is performed within or near the institution. The contractor pays the state a stipulated amount per capita for the services of the convict, supplies his own raw material, and superintends the work. 
[The contractor may have free use of heat, light, power, and water, or he may be charged for these items.]

Piece-price system. This system differs from the contract system mainly in method of payment for the labor of convicts. The state maintains the institution and feeds, clothes, and guards the convicts. The contractor supplies the raw material and pays the state an agreed amount for the work done on each piece or article manufactured by the convicts. The supervision of the work is generally performed by a prison official, although sometimes by the contractors. The officials of the prison not only maintain discipline, but also dictate the daily quantity of work required.

Public-account [state-account] system. So far as the convict is concerned, this system does not differ from the piece-price system, but for the institution it is entirely different. In the piece-price system the contractor finances the business and assumes all the chances of profit and loss. In the public-account system the state enters the field of manufacturing on its own account. It buys the raw material, manufactures and puts the product on the market, and assumes all the risk of conducting a manufacturing business. The state has the entire care and control of the convicts and with them conducts an ordinary factory. The institution may sell the product direct or through an agent.

State-use system. Under this system the state conducts a business of manufacture or production, as in the public-account system, but the use or sale of the goods produced is limited to the same institution or to other state institutions. The principle of the system is that the state shall produce articles of merchandise for its own consumption alone and shall not compete directly with the business of manufacturers employing free labor. ${ }^{1}$

The states-use system is a projected extension of the state-use principle to make possible the

\footnotetext{
${ }^{1}$ Convict Labor in ro23, pp. 3-4.
} 
sale, to the public institutions of one state, of goods produced in the prisons of another. The National Committee on Prisons and Prison Labor is the leading advocate of the plan.

A form of state-use work is the public-worksand-ways system, under which prisoners are employed to construct roads or buildings belonging to the state.

The state-use theory is an expansion of the practice of using prisoners to do the necessary work of their own institutions. In a large sense, all maintenance work, all shop work connected with maintenance, all farming to supply the institution's table, all production of garments and articles used in the institution-all this is state-use work, quite as much as the production of articles for the state or for other institutions of the state. ${ }^{1}$ However, in collecting and discussing data, it is desirable to separate maintenance work and (whenever possible) all work done strictly for the institution - a division we have uniformly attempted to make; if one wishes to give such institutional work a special name, it may be called employment under the "selfsustaining" system.

It is possible to divide these various systems on the basis of management and also on the

\footnotetext{
1 The terms "state-use" and "state-account" as applied to systems of prison labor mean employment for government or public use or account, and therefore may describe such employment when managed by a county, a municipality, or any governmental unit.
} 
basis of distribution of products. On the first basis, the lease, contract, and piece-price fall into the class of privately operated systems; the other four are state operated. On the second basis of classification, prison products or prison labor under the lease, contract, piece-price, and state-account systems come into direct competition with free industry, possibly affecting market prices, wages, and employment. Under the state-use, states-use, and public-works-andways systems, competition is less direct.

Present Distribution of Prison Workers by Systems

Table $\mathrm{X}$ summarizes the daily work sheets given in the 1929 Handbook and shows the number and percentage of prisoners employed under each of these systems, in ninety-eight institutions during the period 1927-28. Since the piece-price method is merely one form of the contract system, it is included in the contract column.

Beginning with the total number employed, this figure is divided as in Table III to show how many are employed on maintenance, or work solely for the institution ("self-sufficing" or "self-sustaining"), and how many are employed at productive work. The number of those productively employed is then subdivided according to methods of employment - lease, 


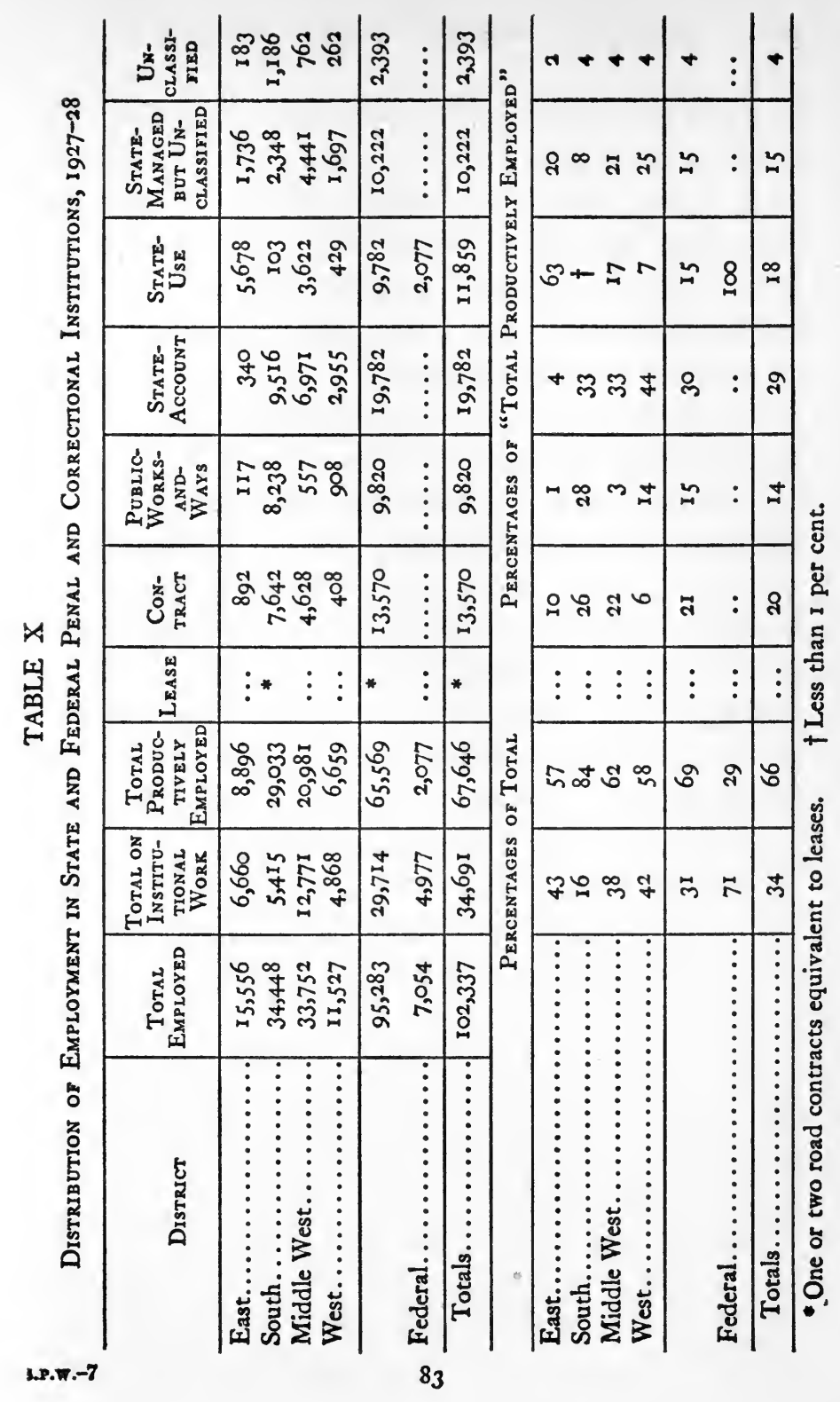


contract, public-works-and-ways, state-account, state-use. Often, where data are incomplete, prisoners cannot be listed as working for the state's account or the state's use, but they are known to be employed under state management, and so are put in a distinct column, "state managed but unclassified." In many states there is yet another group known to be employed, but which cannot be classified at all.

The first point of interest is the large proportion of prisoners used on strictly institutional work - 34 per cent of the total number employed. The South reports by far the lowest percentage so employed (16) and the East the highest (43); West and Middle West are in a class with the East, having percentages of 42 and 38 respectively. The proportion of maintenance assignments in Federal prisons is unusually high - over 70 per cent. This is a result of serious overcrowding and the restrictions imposed by state-use regulations. Such a percentage is of course far too great from the point of view of efficiency, and indicates a degree of overassignment which destroys the possibility of vocational value in any of the maintenance details.

Having already (in Chapter II) considered the implications of the figures on productive employment as a whole, we are here interested in the systems under which this large productive labor 


\section{SYSTEMS OF EMPLOYMENT 85}

force is managed. We find first of all that the much-reviled lease system is chiefly conspicuous on this table by its absence.

Of all prisoners productively employed in I927-28, 20 per cent were working on contracts, I4 per cent on the public works and ways, 29 per cent for the state's account, and 18 per cent for state use; I 5 per cent were under state management of which the exact type is not specified, and 4 per cent were not classified at all as to system of labor. These percentages offer an interesting comparison with similar ones obtained in 1923 by the Bureau of Labor Statistics, ${ }^{1}$ and we have here arranged them together:

\section{TABLE XI}

Systems of Prison Employment, I923 AND I928 Percentages $1923 \quad 1928$

Contract (including all work done on a per diem, piece-price or cut-make-and-trim basis)..... I9 20

Public-works-and-ways.................. I9 I4

State-account....................... 26 ${ }^{26}$

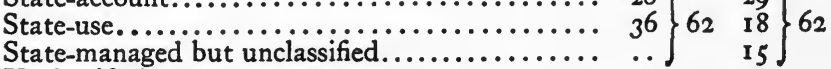

Unclassified..$\ldots \ldots \ldots \ldots \ldots \ldots \ldots \ldots \ldots \ldots \ldots \ldots \ldots$

$\frac{\cdots}{100} \quad \frac{4}{100}$

The proportion employed at contract shows little or no variation, which indicates that the system was holding its own until the passage of the Hawes-Cooper Bill; also, the states reporting contracts in 1928 were with one or two minor exceptions the same which held contract

'Convict Labor in 1923, pp. 2-3. 
or piece-price agreements in $1923 .{ }^{1}$ There is a difference of 5 per cent in the numbers employed on road work in 1923 and 1928 - due partly to the 1928 unclassified percentage and partly to the fact that the 1923 figures are average, while the 1928 figures are not, which does not allow for seasonal variation. The state-account percentage rises a little in the five years and the state-use percentage drops off exactly half, but if we combine all the state-managed types of industry the percentage for the group shows no change from 1923 to 1928 .

Considering only those prisoners productively employed in 1928, the contract system accounted for 26 per cent in the South, 22 per cent in the Middle West, Io per cent in the East, and 6 per cent in the West; public works and ways gave employment to 28 per cent in the South, I4 per cent in the West, 3 per cent in the Middle West, and only I per cent in the East; stateaccount industries employed 44 per cent in the West, 33 per cent in the Middle West and South, and but 4 per cent in the East; state-use shops accounted for 63 per cent in the East, I7 per cent in the Middle West, 7 per cent in the West, and less than I per cent in the South. The large percentage of workers under unspecified types of state management in the West,

\footnotetext{
1 Compare detailed tables by states, Appendix II, with Conoict Labor in ro23, pp. 20-3, Table A.
} 
Middle West, and East $(25,21$, and 20 per cent respectively) emphasizes the fact that the proportions given for state-account and state-use industries in these sections are valuable only as minimum figures. Nevertheless the East is plainly the stronghold of the state-use system. The percentage of productive workers unclassified in any way is small in each section.

Keeping in mind the general picture of the extent to which the systems are used in different parts of the country, let us now turn to a more detailed consideration of each one.

\section{The Lease System}

Leasing is undoubtedly the easiest way out for a state or local unit of government that does not wish to wrestle with the problems of caring for its prisoners, particularly the very difficult task of finding employment for them. Its origin may be traced to reconstruction days. When the penitentiary of Georgia had been burned and there was little hope of obtaining funds from state revenue for a new prison, General Ruger of the Federal army decided to lease the convicts, thus instituting a system that has lasted until the present time but now seems doomed to extinction. It has long been completely discredited on account of the very serious abuses to which it is liable, since prisoners are generally turned over without adequate 
supervision to private parties whose one thought is profit, not the care of their workers. Abuses are not only possible but have occurred, when the state thus washed its hands of its responsibility.

Since neither land nor capital is furnished to the lessee by the government, his advantage from the point of view of competition lies wholly in the cheap labor supply. The very fact that a private concern will go to the trouble of housing, feeding, and guarding the prisoners proves that there is some economic advantage in using them.

This system has now been officially given up in all the states, at least so far as state prisoners are concerned. Leasing of county prisoners is still permitted by law in Kentucky and Louisiana; ${ }^{1}$ whether it is actually done or not is another matter. The newspapers of late August, I930, carried a story of rioting by Louisiana state convicts quartered on a privately owned rice farm. The trouble, said to be caused by meager rations and severe punishments, resulted in the death of one prisoner, whose widow brought suit for damages against the governor, the general manager of the penitentiary, and the owner of the farm, claiming that the manager contracted with the owner to operate the farm

${ }^{1}$ Monthly Labor Review, XXVIII (March 1929), 130. The National Committee on Law Observance and Enforcement states that leasing is still legal in Louisiana, North Carolina, and Arkansas. Op. cit., p. 82. 
by convict labor, on equal shares. ${ }^{1}$ According to other dispatches, ${ }^{2}$ the Attorney General declared the contract was illegal.

Leasing of prisoners whether state or county has been illegal in Florida since $1923{ }^{3}$ following publicity given the death of a county prisoner in a private camp. But apparently the system is not extinct in spite of the law, for the 1929 Handbook reports the existence of one leased camp (taking county prisoners), ${ }^{4}$ and an article appearing in the New Republic of April 8, I93I, tells first-hand how a young Northerner was arrested near Tallahassee for riding a freight train and (as he could not pay the $\$ 25$ fine) was sent sixty miles into the swamps to a lumber camp operated by a private firm. The exact date is not given; we gather that the occurrence took place in the winter of $1930-31 .^{5}$ The leasing of both state and county prisoners is apparently still legal in Idaho and South Carolina, ${ }^{6}$ but it is not done with state prisoners in either. Alabama, the last state to maintain the practice for state prisoners, discontinued its leases on

${ }_{1}^{1}$ New York Times, August 31, 1930.

${ }^{2}$ Philadelphia Record, August 27, 1930, and Nerwark (N. J.), News, August 29, 1930; quoted by National Society of Penal Information, News Bulletin (October 1930), p. 14.

3 General Laws, ch. 9203 (No. 85), quoted by Department of Agriculture, Prison Division, 20th Biennial Report (I927-28), pp. 70-4.

4 P. 234.

5I. H. Schwartz, "Welcome to Our Chain Gang!" New Republic, LXVI, 200-2.

'Monthly Labor Review, XXVIII (March 1929), I29-35. 
June 30,1928 , with the closing of four mines as prisons. ${ }^{1}$ In North Carolina some of the state's road contracts for prison labor bear a strong resemblance to leases. ${ }^{2}$ This is a good example of how the systems outlined above can be confused with one another until the original points of classification are lost: here is a state contracting the labor of its prisoners to a private party for the construction of state roads; this can be called neither contract nor public-worksand-ways labor - it is the employment of prison labor under private management for public purposes, and at a profit to the private party.

\section{The Contract System}

The contract system has been under fire for at least a century, practically ever since the time of its introduction into American prisons. Trouble arises partly from the fact that the main motive for the work is profit on the part of the contractor, and if he is allowed to set the "task" (the day's work quota), enforce it, supervise the work, and pay the foremen, the result has all too of ten been a system of vicious exploitation. Kate Richards O'Hare has described her experience with contract labor in the State Peniten-

1 American Year Book (1928), p. 491.

Ig29 Handbook, p. 724. As separate data were not given to show how many road camps were state managed and how many were under contract, the men thus employed are all represented in the column Public-Works-and-Ways. 
tiary at Jefferson City, Missouri, ${ }^{1}$ in 1919-20. The picture she draws is one of convicts worked under sweat-shop conditions and driven by brutal punishments; she blames the abuses and brutalities on the task method and the practice of paying low wages to foremen but granting them a bonus for all the work they can exact beyond a minimum. ${ }^{2}$ The atrocities possible under these circumstances have received wide publicity and the contract system has been condemned almost as roundly as the lease system.

Contract prison labor is not necessarily an unmixed evil even from the prisoner's point of view, and, in efficiency of management and financial return to the state, contract shops are usually superior to state-managed ones. Many contract shops today secure the task by means of bonuses paid the worker for all articles produced in excess of the requirement. The greater effectiveness of this method is being recognized more and more. Conducted under proper supervision, a contract shop need not be-any worse for the worker than a shop run by the prison. For instance, the authors of the ro29 Handbook, in commenting on the piece-price shoe shop at the Vermont State Prison, praise several features of the work and remark that "few of the faults

\footnotetext{
${ }^{1}$ In Prison (New York, 1923), pp. 99 ff. "The Story of the 'Big
} Yank," The American Vanguard (May I924), Reprint No. 42, pp. 2-5.

2 "Human Ostriches," Nation, CXX (I925), 378. 
considered inherent in the contract system are found here." 1

A difficulty is that prison contracts have often been drawn in a rather one-sided fashion, the state apparently not taking the trouble or not being able to secure a good bargain. The typical contract quoted in the Department of Commerce report gives the contractor a renewal option on written notice and allows him the privilege of cancellation on ninety days' notice -

... if it shall be or become unlawful, by the laws or regulations of the United States of America, or the state of ... to manufacture the product covered by this agreement, with aid of prison labor, or sell or transport the same, or if the marketing of such products shall be materially restricted by operation of law. ${ }^{2}$

The state has no cancellation privilege. Otherwise the agreement is fair enough: the workshop and men up to the number of 250 to be supplied by the prison; the machinery, raw material, and supervision by the contractor, who pays a lump sum for light, heat, water, and power, and for hauling to and from the railroad, in addition to a specified amount per dozen work shirts $\left(42 \frac{1}{2}\right.$ to 50 cents depending on style). Discipline is declared to be in the state's hands. The exceptional Vermont contract just mentioned, which worked admirably for the

1 1929 Handbook, p. $93^{8}$.

2 Prison Industries, pp. 108-9. 
prison, was not profitable to the contractor. ${ }^{1}$ Manufacturers only go in to the business because they see a chance for easy profits; if prison authorities make too many stipulations or raise the labor price, they may get no contract, and be faced with the problem of handling hundreds of idle men.

Contract labor is now illegal in all Federal penal institutions and in seventeen states: California, Illinois, Indiana, Massachusetts, Minnesota, Missouri, Montana, New Jersey, New York, North Dakota, Ohio, Oklahoma, Oregon, Pennsylvania, Texas, Utah, Washington. ${ }^{2}$ Yet contracts were reported to be in force in Oklahoma on March 5, 1928, and in Indiana in April and May of that year; while Missouri operates some of its industries on the "cut-make-andtrim" method, which is as similar to contract as is piece-price. ${ }^{3}$

While there have been many reasons for objecting to the contract system on purely humanitarian grounds, the effective opposition has come largely from those who objected to it for the economic reason of unfair competition. As with

1929 Handbook, p. 938.

2 Federal and State Law Relating to Convict Labor, p. 180; Monthly Labor Review, XXVIII (March I929), 127-37.

3 "Under the cut-make-and-trim form, which has been applied to shirts and overalls, the contractor supplies the cloth, already cut, and the prisoners sew it into finished garments, the state supplying buttons and thread. The labor is paid for on a piece-work basis." E. R. Cass, "Prison Labor," Prison Association of New York, 83rd Annual Report (I927), p. 84 . 


\section{SHOULD PRISONERS WORK?}

the leasing of prisoners, governmental authorities must offer some kind of an inducement to private contractors to interest them in using prison labor. The officials in charge can offer not only cheap labor but also cheap land and capital, for, since the manufacturing takes place on the prison grounds, the land, workshops, etc., may all be furnished to the contractor at a far lower cost than that at which he could obtain such facilities elsewhere. It all depends, of course, on the bargaining power of the government, but some economic inducement and, therefore, some advantage must be offered to the contractor. Not being able to equalize the conditions of competition, outside labor and manufacturers have struck at the system itself by attempting to destroy the market.

\section{The Piece-Price System}

The piece-price system was developed to meet the humanitarian objections to the contract system, of which it is but a variation, from the marketing point of view. Since the state or other governmental unit retains complete control of the prisoner, keeping all discipline in its own hands and setting the daily work task, no complaint can be made that greedy private interests use slave-driving methods. The situation that then arises is well illustrated in the State Prison at Howard, Rhode Island. "Here 
the state owns its own machinery and pays its own foreman; the contractor furnishes the raw material, manufacturing specifications, and shipping directions. Except for inventory purposes, the contractor has no representatives in the prison." ${ }^{2}$ This takes the industry out of the privately operated class and puts control as fully into the hands of the state as does the stateaccount system. But the economic situation is not altered, for the goods are sold on the open market and the cost of production is low. The effective hostility is therefore as great as to the contract system in its per diem form.

\section{The State-Account System}

The state-account system goes a step farther than the piece-price system - it shuts out the con tractor absolutely. The state or local government not only makes the goods but it decides what to make, buys the raw material, and sells the finished products, assuming the rôle of entrepreneur and entering fully into business with all its risks and uncertainties. On humanitarian grounds, the method offers no advantages over piece-price contracts, since the state is equally in charge of living and working conditions. Though there have been some conspicuous financial successes with this system, we are inclined to think that its main superiority to the

${ }^{1}$ jgag Handbook, p. 87 . 


\section{SHOULD PRISONERS WORK?}

piece-price system is the political advantage of being able to declare that the contractor has been banished and that private interests are not fattening on the prisoner. The prisoner may of course benefit in case the state undertakes production which has greater educational and training value.

Those who object on economic grounds to the contract and piece-price systems look with disfavor on the state-account system also. Since state-directed enterprise is usually less efficient than private business, the competition is probably not so severe as would be experienced from goods produced under either the contract or piece-price systems. Nevertheless, as the goods are manufactured by plants operating with abnormally low costs for land, capital, and labor, and are sold on the open market, often through large jobbing houses, competition may be acutely felt. The Missouri State Penitentiary at Jefferson City officially abolished contract labor as of June 22, I9I $7,{ }^{1}$ although Mrs. O'Hare states that the law was evaded by means of a pieceprice contract when she was imprisoned there. ${ }^{2}$ The Revised Statutes of I9I9 forbade "the contracting of convict labor in any form or manner, directly or indirectly. .. "3 In I92I a revolving fund for prison industries was established;

1 Prison Industries, p. 53.

${ }^{2}$ In Prison, p. IOI.

3 Convict Labor in 1923, p. 213. 
in 1925 a change in administration resulted in a famous case of "dumping" over a million dollars" worth of garments, an event which is said to have demoralized the market. ${ }^{1}$ The Biennial Report of the Department of Penal Institutions for $1925-26$ referred to this episode and explained that a loss of $\$ 97,622$ on work shirts "was sustained by merchandise carried over from the previous administration. It was necessary to take a loss on the merchandise on account of the heavy decline in cotton goods." ${ }^{2}$ A detailed explanation of the affair is as follows:

... In I921 a revolving fund of $\$ 750,000$ was established to maintain the prison industries and an additional $\$ 500,000$ was advanced later.

On January I, 1925, a new management took charge of the prison industries. After a complete reinventory and scrapping of unsalable items, the books showed $\$ 574,000$ in accounts payable, $\$ 584,000$ due for materials bought but not delivered, and practically nothing in the bank. An examination of stock and inventory on hand showed $\$ 1,300,000$ worth of materials and goods made up, mostly in odd sizes which could not be sold except at a sacrifice. Of approximately 2,600 prisoners in the institution, 500 were employed in the prison factories, and over 2,000 were either idle or engaged at the prison on maintenance jobs. A complete house cleaning in the prison administration resulted, and during the first three months of 1925 it is recorded that officers placed on the market over $\$ 1,000,000$ worth of garments for whatever they would bring. During that period, prison-made over-

1 Prison Industries, p. 54.

2 P. I9. 


\section{8} SHOULD PRISONERS WORK?

alls, for example, which cost the outside manufacturer $\$ 12.50$ to produce, were sold, it is alleged, at $\$ 9$ a dozen. ${ }^{1}$

Since then Missouri has resorted to the cutmake-and-trim arrangement already described, which is sure to encounter the obstacles made possible by recent legislation. It is safe to predict that market restrictions will interfere with the development of state-account industries as well as with the cut-make-and-trim subterfuge, and make the task of many prison administrators still harder.

\section{The State-Use System}

The struggle to get rid of competition from prison-made goods has helped to develop the state-use system, under which the open market is closed by law, and public authorities are either required or offered a chance to buy the goods produced by the prisons. The force that brought this system into being is plain to see. Since under the piece-price and state-account systems full control of the welfare of the prisoner remains in the hands of governmental authorities, the definite curtailment upon selling the goods (the distinguishing mark of the state-use system) is due entirely to those who feel themselves injured by competition. Even though a prison industrial plant is run inefficiently by public officials, it can offer serious competition. As was said in

\footnotetext{
1 Prison Industries, p. 15.
} 
the previous chapter, the prisoner must be fed, clothed, housed, and guarded. Any return from prison workshops over and above the cost of raw material, additional floor space, machinery, and small wages (which do not need to be paid), will be an inducement to the state or local government to carry on, since even a slight reduction in the cost of maintaining the prison will be something saved.

But the desired elimination of competition under the state-use system is more apparent than real. If the entire market for goods is represented by a circle, the effect of the state-use system is to limit the sale of prison-made goods to a sector in which are included the purchasers for state and local government departments and state and local institutions. Many persons fail to realize that, if the system really worked according to plan, the withdrawal of these buyers from the market would be as disastrous to the price level as the sale of the same quantity of goods on the open market. It does, however, have this advantage: after a period of time sufficient to bring about the readjustment necessitated by the withdrawal of government bidders, the competition is not then apparent and probably not so destructive, since the danger of price cutting is removed. In other words, if free labor and free manufacturers are themselves willing to submit to a restriction of s.P.w. -8 


\section{IOO SHOULD PRISONERS WORK?}

their markets in order to avoid the appearance of prison-made goods in a competing market, some progress toward the solution of this difficult problem of prison labor has been made.

We must also not overlook a real gain in prison welfare that has come as a by-product of the restriction imposed on the sale of goods by the state-use system. From the point of view of vocational training and giving the prisoners work which will have real occupational value on their release, the contract, piece-price, and stateaccount systems are all likely to be unsatisfactory, because to be profitable they must as a rule concentrate on one line of production which may or may not be suitable for most of the prisoners. Then, too, a contract requiring the services of a specified number of men is especially likely to interfere with any attempt at scientific classification of the prisoners. State-use work, on the other hand, has the advan tage of requiring considerable diversification of industry if the various needs of state institutions are to be met, thus providing the opportunities for occupational training in many lines. The strong tendency, now manifest, to locate penal institutions on large tracts of land in the country has undoubtedly been strengthened by the necessity of finding something for idle prisoners to do. In all probability the state or local government is not so well off financially as it would be when 


\section{SYSTEMS OF EMPLOYMENT IOI}

using the piece-price or state-account systems, but the prisoner may gain in health and training. Yet the possibility of paying wages to prisoners depends in large part on an industrial system that is financially successful, and it may be that the prisoner would profit more from well earned money than from living in the country and receiving the kind of training he gets in prison.

The state-use system is difficult to administer. It predicates a number of relatively small industrial shops in each prison, with a welltrained foreman running each; goods must be well made or state institutions cannot be expected to take them; products must be standardized to some extent if any degree of efficiency is to prevail; and, finally, the various hospitals, eleemosynary institutions, schools, and other public purchasing agencies must be forced or induced to buy the goods. This calls for salesmanship, diplomacy, and coöperation between the various state departments - a thing not always easily obtained. The present tendency to centralize all state purchasing in one department, under a responsible cabinet head, ought to make the state-use system simpler and easier to administer, but improvement in sales organization does not by any means remove all the difficulties.

No state-use law can be effective without a clause forbidding public institutions, depart- 
ments, and agencies to purchase from another source any articles manufactured in the prisons, unless the prison industries are unable to fill orders. Even such a clause will not produce orders unless penalties for violation are prescribed and inflicted. The New York law on this point has been evaded notoriously, while the Ohio Department of Public Welfare reports that "no prosecutions have ever been initiated from any source" for even obvious violations of the compulsory-purchase requirements in that state. ${ }^{1}$ Massachusetts, on the other hand, owes much of its relative success with the state-use system to vigilant application of the compulsorypurchase paragraph of the law.

In Massachusetts and New Jersey, surplus products may be sold on the market after state needs have been supplied, but New Jersey operates its prison shops without making use of this permission. Massachusetts penal and correctional institutions sold goods worth $\$ 1,235,303$ to other state agencies, and goods worth $\$ 316,504$ on the market, in the year ending November 30, 1929; brushes and shoes are the only articles entering the general market. ${ }^{2}$

Exclusive state use in Ohio and New York results in appalling idleness. In Ohio $\mathrm{I}, 243$ are listed as idle out of a penal population of

${ }^{1}$ Eighth Annual Report (1929), p. 80.

Commissioner of Correction, Annual Report (1929), p. 185; also letter from Deputy Commissioner, December 27, 1930. 
8,234 , and of the 5,980 listed as working many do not really have full jobs, while the maintenance details are heavily overloaded. ${ }^{1}$ New York lists very few idle, but semi-idleness is rife, according to the data given in Chapter II. In Pennsylvania the state-use shops at Western Penitentiary employed only 279 men out of a total population of I, IO2 on November 27, I929. Another 486 were engaged on maintenance jobs, 205 were in vocational training groups, and the balance of $\mathrm{I}_{32}$ were sick, idle, or under punishment. ${ }^{2}$ The daily average population of both branches of the Eastern Penitentiary was I,908 for the year ending May 31, 1929; an average of 286 were employed in the state-use shops, 273 in the shops maintained by the penitentiary, $35^{2}$ on construction, 358 on maintenance, and 154 on individual arts and crafts work for private sale. This leaves 485 to be distributed among the sick list, the school group, the idle, and those under punishment. ${ }^{3}$ Massachusetts and New Jersey are much more successful.

No other state has yet adopted the system on a large scale; in the South it is negligible, in the Far West relatively unimportant, in the Middle West subordinate to state-account and contract. The smaller and less populous states find it

1 Cf. Appendix I; also 1929 Handbook, pp. 743, 747, 755, 763, 773.

2 The Prison Labor Problem (leaflet published by Pennsylvania Prison Society, 1929).

3 Annual Report (1929), pp. II, 31. 


\section{IO4 SHOULD PRISONERS WORK?}

particularly difficult to operate, since their moderate institutional needs are quickly oversupplied by prison shops operating on a production basis; a small governmental unit simply does not have sufficient state-use market within its own borders to keep more than a fraction of its prisoners busy. Nevertheless the Hawes-Cooper Act passed by Congress will undoubtedly force a wider use of the method, thus necessitating the appointment of more efficient and skilful administrators for prison industries.

\section{The States-Use System}

The National Committee on Prisons and Prison Labor has broadened the conception of the state-use system and advocates that a state producing under it be given permission to sell its products to the public departments and the public institutions of other states. This scheme is called the states-use system. It would give a broader market to prison goods and permit the allocation of industries among the different states. For example, one state might manufacture shoes, and another, clothing, and by this division of labor increased economy and efficiency would result.

The National Committee supports the establishment of state-use shops in all states, and undertakes to market surplus products through the Associates for Government Service, Inc., an 
organization set up for the purpose. The idea is that if production of a certain commodity in the prison shops of one state outruns the demand of the state and its institutions, the Associates will then attempt to sell that surplus, on a commission basis, to the agencies of another state which does not produce all it needs of the article in question. To do this effectively, the Associates endeavor to establish specifications and standards, that goods may be of high quality and reliable, and to survey the potential state-use market with a view to determining scientifically the actual industries which are practical for prison use and which supply government needs. ${ }^{1}$

Another function of the Associates is to promote and facilitate the allocation of prison industries in adjacent states. Since 1924, seven or eight regional conferences have been held on the subject ${ }^{2}$ and the matter has been repeatedly brought before the governors' conferences.

The manufacture of automobile license plates might be used to illustrate the problem of allocation. Tag shops do not require a large number of men in proportion to output; in Pennsylvania Ioo men made all the I929 tags in nine months. For each state to maintain a

\footnotetext{
${ }^{1}$ Governors' Conference, 1925. Section meeting on Prison Administration and State Coöperation in Prison Made Goods, Excerpts from Minutes (National Committee on Prisons and Prison Labor), pp. 5-7.

2 National Committee on Prisons and Prison Labor, Annual Report (1928), p. I9.
} 


\section{IO6 SHOULD PRISONERS WORK?}

tag plant which can fill its own needs inside of six or eight months, or less, and which then must stand idle is poor economy. The Kansas tag plant operated four months in 1929, the Colorado plant six, the Alabama shop only one and a half. At present, license-tag plants are installed in twenty-two states, ${ }^{1}$ and some interstate buying in tags has taken place. Virginia bought its 1924 license tags from the New Jersey State Prison at Trenton, and, according to former Governor Trinkle, other articles had been bought "from Massachusetts and other States." 2 The Associates for Government Service were instrumental in making these sales. South Dakota bought its automobile tags from Iowa in 1928, Alabama purchased its tags from Michigan in 1923. Strange to say, the Alabama board "was subjected to much criticism for making a contract with a state prison," 4 when Alabama's own convicts were bringing in more profit for the state than prisoners anywhere else in the country. All three of these states - Virginia, South Dakota, Alabama have since installed tag shops of their own. Washington sold tags to Idaho in $1927,{ }^{5}$ but in 1929 Idaho bought its tags from a private

1 Prison Industries, pp. I06-7; 1929 Handbook, p. 792.

2 E. Lee Trinkle, Our Prison Industries (Richmond, I923), p. 5.

3 State Board of Charities and Corrections, 2oth Biennial Report (1928), p. 5 .

State Board of Administration, 2uadrennial Report (1926), p. I1.

- United States Daily, V (July I4, I930, Supplement), 22. 
concern. ${ }^{1}$ Oklahoma is reported to have made auto tags for New Mexico and Tampico (Mexico), and road markers for Mississippi and the United States Government. ${ }^{2}$ (This example indicates how tag shops may be developed into sheet-metal shops making a variety of objects sufficient to keep the machines going all year.) A table for 1929 in Prison Industries shows seventeen states and the District of Columbia making their own tags in prisons, and thirty buying them from private concerns. ${ }^{3}$ Oklahoma should be added to the seventeen. Four of the thirty (Georgia, Louisiana, North Carolina, South Dakota) were planning to make the I930 plates in their prisons. Three others had bills in their respective legislatures proposing to make the tags in prison, and the installation of a tag plant had been recommended in Kentucky. ${ }^{4}$ So there would seem to be but a poor future for license tags as a states-use product. Minnesota failed to buy its I93I license tags from the Indiana State Prison because of the Minnesota law requiring that prison products be branded. ${ }^{5}$

Extensive allocation would work against that diversification of industries which we have already noted as one of the advantages of the

\footnotetext{
1 Prison Industries, p. 107.

2 Montana State Prison, 25th Biennial Report (1925-26), p. 4.

8 Pp. $106-7$.

4 State Board of Charities and Corrections, Report (1928-29), p. 76.

- United States Daily, XV (July 14, 1930, Supplement), 21.
} 


\section{I08 SHOULD PRISONERS WORK?}

state-use system. The states-use plan has also been criticized as impractical on account of the large amount of coöperation necessary between the states, and because some organization would be required to handle the details. ${ }^{1}$ The Associates for Government Service aim to supply the necessary organization, but it is extremely doubtful if a private corporation will succeed in establishing itself as a distributing agency for a number of state industries, especially when prison administrations are subject to periodic changes and the dictates of each succeeding legislature. The whole plan predicates a stability of organization which very few of our state penal systems have attained. And the one or two which are well enough organized to embark on a plan of exchanging surplus products are able to handle the transactions without outside help. Mr. E. R. Cass observes that "if the states through their various official departments cannot arrange for the exchange of prison-made goods . . . , then it is a sad reflection on the intelligence and ability of their officials." 2

Recent Legislation Affecting Prison Labor

The efforts of the American Federation of Labor, the Manufacturers' Conference on Prison

1 E. W. McCullough, "Some Observations of Business," American Prison Association, Proceedings (1926), pp. 250-I.

2 Letter dated July I, I93I. 
Industries, the General Federation of Women's Clubs, the National Committee on Prisons and Prison Labor, the United States Chamber of Commerce, and similar organizations ${ }^{1}$ finally resulted in the passage by the Seventieth Congress of the Hawes-Cooper Bill (H. R. 7729, Public No. 699), the text of which follows:

$\mathrm{Be}$ it enacted, etc. . . That all goods, wares, and merchandise manufactured, produced, or mined, wholly or in part, by convicts or prisoners, except convicts or prisoners on parole or probation, or in any penal and/or reformatory institutions, except commodities manufactured in Federal penal and correctional institutions for use by the Federal Government, transported into any State or Territory of the United States and remaining therein for use, consumption, sale, or storage, shall upon arrival and delivery in such State or Territory be subject to the operation and effect of the laws of such State or Territory to the same extent and in the same manner as though such goods, wares, and merchandise had been manufactured, produced, or mined in such State or Territory, and shall not be exempt therefrom by reason of being introduced in the original package or otherwise.

SEc. 2. This Act shall take effect five years after the date of its approval. (Approved January 19, 1929.)

This measure is primarily directed against the contract and the piece-price systems and secondarily against the state-account system; its effect will be to restrict greatly and to narrow the market for prison goods. Sixteen states already have laws requiring that prison-made

\footnotetext{
${ }^{1}$ National Committee on Prisons and Prison Labor, Annual Report (1928), p. 7 .
} 


\section{IO SHOULD PRISONERS WORK?}

goods be so labeled, ${ }^{1}$ and other legislative requirements such as diversification of industries, short work days, special license to sell, etc., were mentioned in the preceding chapter. In the past, such legislation has been held unconstitutional when it was applied to goods in interstate commerce, ${ }^{2}$ but the Hawes-Cooper Act gives a state full authority over prison goods sold within it, even though made outside. The only thing a state cannot do, apparently, is to discriminate in its regulations against prison goods from outside: i.e., if it restricts the sale of such products in any way, it must restrict the sale of its own prison products similarly. ${ }^{3}$

As we have already pointed out, the contract labor system is illegal in seventeen states, and this law makes it possible for these states to prevent absolutely the sale, within their borders, of goods produced under the contract system. It is of course useless without the supporting state legislation, but there is reason to believe that this will be forthcoming. The American Federation of Labor is recommending seven "model amendments to be introduced in the state legislatures" - that is, each state federa-

${ }^{1}$ Monthly Labor Review, XXVIII (March 1929), 127-37; Prison Industries, p. 4, note 3 .

${ }^{2}$ Federal and State Laws Relating to Convict Labor, p. 33; A. H. Schwartz, "Legal Aspects of Convict Labor," Fournal of Criminal Law and Criminology, XVI (Aug. I925), p. 274.

${ }^{3}$ Dr. George W. Kirchwey believes the Act may quite possibly be declared unconstitutional, if (as is likely) a test case reaches the Supreme Court in 1934; letter of August 21, I93I. 
tion is ready to propose state-use amendments to the prison law in question. The second of the seven recommendations from headquarters reads as follows:

2. After January I9, I934, no goods, wares, or merchandise manufactured or mined by convicts or prisoners of other states, except convicts or prisoners on parole or probation, shall be shipped into this state to be sold on the open market, or sold to, or exchanged with, an institution of this state or with any of its political divisions. ${ }^{1}$

A law almost identical with the above passed the New York legislature in 1930.2 Granting its constitutionality, the possibilities of the clause quoted are evident. It even rules out states-use. Having got carte blanche from Federal restrictions, the unions are evidently going ahead to force exclusive state-use laws wherever they can, and a law such as they advocate would effectually kill even most state-use industries or else lay the state open to the charge of discriminating against goods from other states. Union labor is especially strong in New York, where the stateuse system has been a part of the constitution since I894. It happens that whatever New York does in the matter is particularly important, because most goods produced in prisons and sold on the open market "are sold through New York City."3 New Jersey has recently

${ }^{1}$ Convict Labor: Model Amendments To Solve Prison Labor Competition (Washington, 1930), p. 7 .

${ }^{2}$ Laws of 1930 , ch. 136.

${ }^{3}$ The Business Week (Oct. 12, 1929), p. II. 


\section{SHOULD PRISONERS WORK?}

increased its restrictions on the sale of prison products, in a law corresponding closely to the New York measure. ${ }^{1}$ The same "model amendment" was introduced into the I93I Pennsylvania Legislature, but was passed in a modified form prohibiting prison goods from other states to be sold on the open market, ${ }^{2}$ a restriction already applicable to articles produced in Pennsylvania prisons. Minnesota has enacted a branding law, affecting prison goods from other states as well as its own. ${ }^{3}$ The Wisconsin Legislature passed a bill forbidding the sale of prison products made under contract (whether within or without the state), but it received a pocket veto. ${ }^{4}$

This glimpse of recent legislative developments in several important states shows the trend clearly. Labor interests, supported by manufacturers' organizations, ${ }^{5}$ are consistently endeavoring to make only the state-use system legal the country over, and to prevent any passage of prison products over state lines. This bottling-up process will accentuate prison labor difficulties even in large and wealthy states, while the union insistence that "the prison labor problem is a state problem" ignores or belittles

1 Laws of 1931 , ch. 235.

${ }^{2}$ Laws of 1931 , ch. 308.

${ }^{3}$ Laws of 1929, ch. 138.

4 Act No. 320, A, I931 Legislature.

- Rarely in the history of industrialism has such unanimity been displayed by ordinarily hostile groups. 
the fact that small or thinly populated states cannot possibly absorb all the goods from their prison shops; many such shops will be crippled without a wider-than-state market, and the trade interests know it. Few free industries of any size whatever could live on a market restricted to the states of their location.

Early Results of the Hawes-Cooper Act

The Hawes-Cooper Act is already having some effect. Contractors are not renewing their agreements and state authorities are having difficulty in securing contracts with which to keep their men busy. This was indicated by the significant experience of the Kentucky State Board of Charities and Corrections, when, on the termination of one of its contracts early in 1929, it was able to secure others only after some delay and the cancellation of one existing contract. ${ }^{1}$ The Board states that:

There is a division of opinion as to whether or not the Hawes-Cooper bill is constitutional, but under any circumstances its passage has created an unsettled condition upon the market for prison-made goods and prison contracts. If the law should go into effect, it means that the contract labor system will cease and that the state will have to find other means of employing its three thousandodd prisoners, and the loss of revenue annually in amount sufficient to pay for more than one fourth of the cost of operation of the seven institutions under the control of this Board. [Three of these are hospitals, one a feebleminded institution, one a juvenile house of reform, one

\footnotetext{
${ }^{1}$ Report (I928-29), pp. 29-30.
} 


\section{II4 SHOULD PRISONERS WORK?}

the state reformatory, and one the penitentiary.] Idleness cannot be tolerated in the prisons, and some means of employment must be afforded, whether remunerative to the state or not. Whether this will finally result in the working of prisoners in large numbers on the public roads, and just how far such a plan of road work will be satisfactory, we do not know. Climatic conditions in Kentucky are such that a general program of road work would probably mean complete idleness for the road workers for three or four months each winter. Whether other state employment could be found which would keep the road workers busy during the winter, we are not, at this time, prepared to say. 1

This statement well illustrates the point of view of prison officials now using the contract system, and the predicament in which they find themselves. The Kentucky Board goes on to recommend the installation of two state-use plants: a license-tag shop and a factory for making tin cans. It also recommends the purchase of large farms, so that "a great many prisoners could be employed in farm work, and money might be made by the growing of hemp, tobacco, and other commodities on a large scale." The Board does not seem to realize that if the Hawes-Cooper Bill is applied stringently the sale of farm products on the general market may become no less impossible than the sale of contract-made garments.

The Missouri Department of Penal Institutions, in its Biennial Report for 1927-28, quotes the Hawes-Cooper Bill and comments thus:

\footnotetext{
iReport (1928-29), p. 34.
} 
It is our opinion that the passage and approval of this law strikes a death blow to the manufacturing industries now conducted by the Penal Board at the penitentiary, and while this law may not seriously effect [sic] the industries just at this time, yet, when the law takes effect, it will result in the state being forced to abandon the employment of convict labor in any profitable enterprise. For several years there has been a growing tendency on the part of the public not to purchase or use goods and products produced by convict labor, and it is generally conceded that the law above mentioned not only applies to goods that might be manufactured, by convict labor, but to agricultural products produced by convict labor as well. 1

We have already mentioned the fact that Missouri employs its prisoners partly in stateaccount industries and partly on the cut-makeand-trim method, equivalent to contract.

The Warden of the Indiana State Prison in his I 929 report gives warning that a large percentage of the inmate population will soon be idle "as a result of the passage by Congress of the HawesCooper bill.",2

The Board of Directors of the South Carolina Penitentiary states that the returns from the institution's chair factory for 1929 decreased because of two reasons - general business depression and "the agitation which preceded and followed the passage of the so-called HawesCooper bill by Congress against prison-made goods." 3

1 Biennial Report (1927-28), p. 12.

2 Annual Report (I929), p. 8.

Annual Report (I929), p. 4.

s.P.w -9 


\section{I16 SHOULD PRISONERS WORK?}

The Warden of the Maryland Penitentiary, reporting to the Board of Welfare for the year ending September 30, I929, comments on the decrease in earnings under a new piece-price contract:

Legislation passed at the last session of Congress, which will virtually abolish the contract system within the next few years, has made it increasingly difficult for us to obtain employment for our population and the piece-price contract was made because nothing better was obtainable. ${ }^{1}$

The effects of the Hawes-Cooper Bill have been felt sharply in Wyoming, where the penitentiary has for some years made shirts on contract - first with the Reliance Manufacturing Company, which has achieved a not exactly enviable prominence in the prison contract field, and later with its subsidiary, the Far West Manufacturing Company:

In January, 1930, the representative of the Far West Manufacturing Company went on record as being willing to install enough additional machinery to employ forty more men in the shirt factory. He believed that this expansion was justified by the excellent market and was needed by reason of the increasing prison population. $\mathrm{He}$ assured the [Prison Labor] Commission that although Congress had passed the Hawes-Cooper bill, which would divest certain classes of prison-made goods of their interstate character, and hence would ruin the market for these goods, the five years allowed before this law would go into effect were considered ample time for reorganizing prison labor programs.

${ }^{1}$ Board of Welfare, 7th Annual Report (1929), p. 16. 
In less than three months from this time, a drastic collapse in the market occurred. It was attributed to the general business depression and, more especially, to publicity which conveyed the impression that the HawesCooper bill was already in force. The Far West and Reliance Manufacturing Companies, unable to dispose of the surplus product, asked for a ninety-day shut-down of the plant. It was finally agreed that shirt production be cut down to a minimum of 650 dozen per week for a period of ninety days.

In July it became necessary to renew for a period of six months the arrangement curtailing the weekly output of the factory to not less than 650 dozen. At that time the Far West Manufacturing Company gave notice to the commission that if conditions did not improve by January, I93I, it would have to cancel its contract, in accordance with the clause which stipulated that this could be done at any time, upon I 20 days' notice in writing to the State of Wyoming, in case it should become unlawful by either state or Federal regulation to sell or transport goods made by prison labor.

It is clear that after July I, I93I, the Far West Manufacturing Company cannot continue even its reduced program for utilizing prison labor. This means that the income derived from the factory, which has already dropped from approximately $\$ 4,000.00$ a month to a little over $\$ 2,000.00$ a month, will be entirely discontinued, necessitating increased appropriations for the coming biennium. ${ }^{1}$

These excerpts show the situation which confronts all prisons now employing their men under contract, and state-account industries are faced with much the same problem. One result has been a series of conferences conducted by the

\footnotetext{
${ }^{1}$ State Board of Charities and Reform, Biennial Report (1928-30), pp. 24-5.
} 


\section{8 SHOULD PRISONERS WORK?}

National Committee on Prisons and Prison Labor, of which the latest were the EasternSouthern Conference on State Institutional Labor and a meeting of representatives of the New England states at Providence, both in 1930.

Other results have taken the form of tardy protest by the Governors' Conference of $1930^{1}$ and by the American Prison Association at its 1929 meeting. The Prison Association adopted its resolution of protest only after much discussion and by a vote of 58 to 20 ; the text reads:

Whereas, idleness in penal institutions is destructive of the physical, mental, moral and spiritual welfare of their inmates, and

WHEREAS, productive labor under normal sanitary working conditions in penal institutions is a controlling factor in prison reformation, discipline and order, and

Whereas, penal institutions should be made as nearly as possible self-sustaining, and not be a burden upon the taxpayers of their respective states, and

Whereas, in January, 1929, a bill known as the HawesCooper bill passed Congress, we respectfully request Congress to repeal said bill.

Be It Resolved, that we are opposed to any and all state and federal legislation that would directly or indirectly interfere with the production, manufacture, transportation, or sale of products of penal institutions; that we believe such legislation is unnecessary, unwise, and unfair to the taxpayers, penal institutions, and their inmates. ${ }^{2}$

1 United States Daily, V (July 14, 1930, Supplement), 19-24.

2 Proceedings (I929), pp. 288-9. 


\section{The Public-Works-and-Ways System}

One method of prison employment unaffected by the Hawes-Cooper Bill is the public-worksand-ways system, under which the majority of the prisoners in some southern states are employed. ${ }^{1}$ This is true of Florida, Georgia, North Carolina, and South Carolina. ${ }^{2}$ Climate and the race situation are the two major factors responsible for the wide use of this method in the South, ${ }^{3}$ and the number of prisoners employed on road work in other sections of the country is relatively small. Such work is of course a special form of the state-use system, and all that has been said in the preceding paragraphs concerning that system applies to it, although there are some important differences that should be noted. It frequently necessitates the use of temporary quarters, and the problem of restraint is somewhat modified. As developed in some southern states, many criticisms of it are warranted. Quarters are often insanitary, there is little or no medical care, and no attempt is made to give the prisoners even a taste of educational influences that might prove beneficial on their return to free life. The chains, stripes, and armed guards that generally go with

1 Cf. Steiner and Brown, The North Carolina Chain Gang (Chapel Hill, I927), pp. 4-5.

2 Cf. 1929 Handbook, under each state mentioned.

3 Steiner and Brown, pp. I5, I8. 
the system in the South are not a sight very edifying to the public, and yet one sees such gangs at work on much-traveled roads. In the North the tendency is to use only honor men on road work, doing away with the necessity for close guarding and the use of physical restraints. Employment on new construction projects (also usual in the North) brings them less into contact with the public.

The counties of the South are the largest users of prison labor for road work. In fact it is customary in some of the states to send to county chain gangs all able-bodied convicts, particularly Negroes, regardless of length of sentence. The disadvantages of county management are many, ${ }^{1}$ and better results would probably be obtained under state control. But, as was pointed out in the preceding chapter, we must be careful not to confuse the evils inherent in a system with those that are due merely to poor management. Three counties in Pennsylvania - Berks, Delaware, and Lehigh - have successfully used a number of prisoners on road and bridge work. ${ }^{2}$

It would seem that road work was a desirable and useful form of labor for selected prisoners, not for the whole penal population in most

1 Steiner and Brown, Ch. X.

2 Leon Stern, The County Prison of Allegheny County (Publications of the Pennsylvania Committee on Penal Affairs, 1930), p. 34 . 
states, and that it could well be combined with other forms of work. California has at the present time an extensive public-works-and-ways program, in connection with San Quentin and Folsom prisons. Colorado long operated successful road-building camps with prison labor, beginning in 1908 and ending some time in I928. Road work for convicts, like other forms of prison labor, is advantageous when well managed and disastrous when poorly managed. It can be made a highly useful and successful form of employment, but presents difficult problems of administration, e.g., housing, sanitation, medical care, discipline, escapes. It has been shown that the honor method, intelligently applied, can solve escape and disciplinary problems. ${ }^{1} \quad$ But California works its prisoners successfully in state highway camps under guard, a fact which indicates that under wise management even unselected prisoners might be employed on the roads without resorting to the methods of the southern counties. The Federal Government is now turning to road camps to relieve congestion in its prisons and to provide employment for its growing penal population. It is reasonable to expect that the methods developed by it will prove worthy of imitation by states and counties.

1 Steiner and Brown, op. cit., pp. 96-10I; Tynan, "Prison Labor on Public Roads," Annals, XLVI (March I913), 59. 


\section{SUMMARY}

On the whole, the state-managed systems of prison labor offer better opportunity for proper control and training of the prisoner. Whether the particular system be state-account, state-use (including public-works-and-ways), or states-use, the responsibility is where it belongs and the problem of properly conducting the industry becomes one of management. It should be emphasized that the installation of no one system as such is a solution of prison labor problems. This is especially to be repeated in connection with the state-use system, which is too of ten regarded as a panacea for all our troubles in the prison labor field. A state-use law is but a beginning; it must be carefully drafted in the first place, so as to include a strong compulsorypurchase clause, and then it must be followed up by efficient management and tireless sales efforts. The authorities should be free to dispose of surplus on the market or to other states, and to supplement state-use shops with institutional farming and employment on public roads and building projects. Very few states and very few institutions at the present time make use of any one system exclusively, as the accompanying check list will show. Combinations are not only used but they are desirable, providing greater flexibility in working out the many details of management next to be discussed. 
TABLE XII

Check List: Systems of Employment in State Penal and
Correctional Institutions

\begin{tabular}{|c|c|c|c|c|c|}
\hline State & LEASE & $\begin{array}{l}\text { CON- } \\
\text { TRACT }\end{array}$ & $\begin{array}{l}\text { PUBLIC- } \\
\text { WORKS- } \\
\text { AND- } \\
\text { WAYS }\end{array}$ & $\begin{array}{l}\text { State- } \\
\text { Account }\end{array}$ & $\begin{array}{l}\text { State- } \\
\text { Use }\end{array}$ \\
\hline 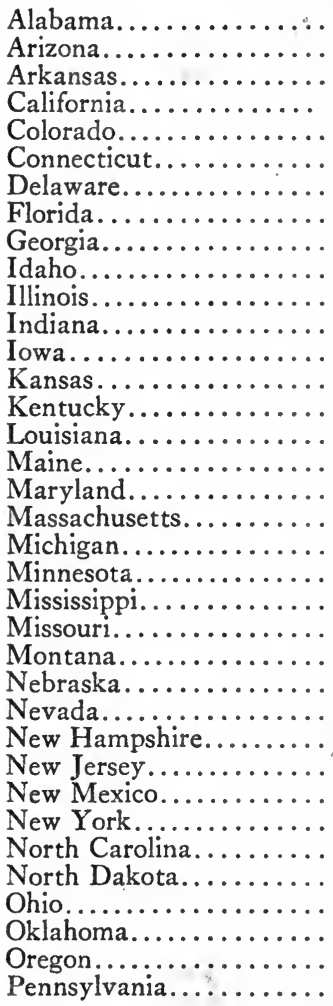 & 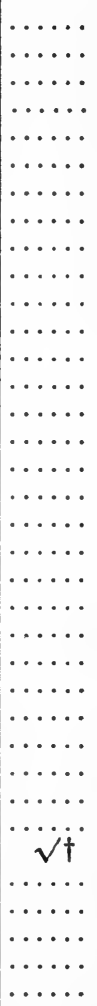 & 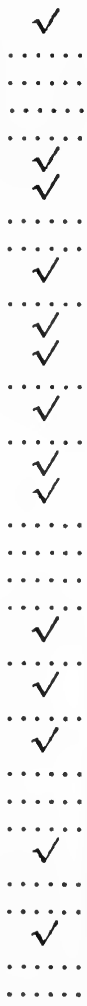 & 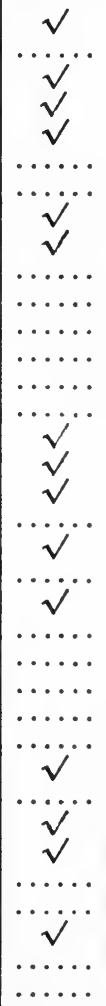 & 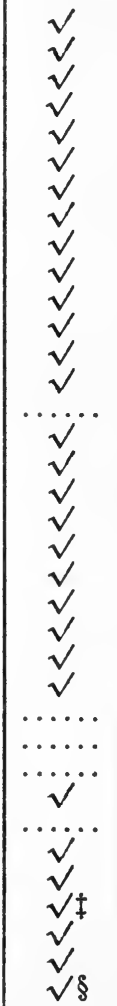 & 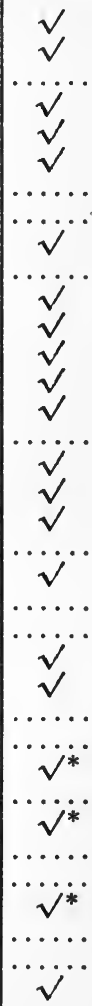 \\
\hline
\end{tabular}

* Exclusively

$\dagger$ Road contracts equivalent to lease

$\ddagger$ Private sale of handicraft products

$\S$ Shops maintained by Eastern Penitentiary 


\section{I24 SHOULD PRISONERS WORK?}

TABLE XII (Continued)

\begin{tabular}{|c|c|c|c|c|c|}
\hline State & LEASE & $\begin{array}{l}\text { Con- } \\
\text { TRACT }\end{array}$ & $\begin{array}{l}\text { PublC- } \\
\text { Works- } \\
\text { AND- } \\
\text { WAYS }\end{array}$ & $\begin{array}{l}\text { State- } \\
\text { Account }\end{array}$ & $\begin{array}{c}\text { State- } \\
\text { Use }\end{array}$ \\
\hline \multirow[t]{2}{*}{ 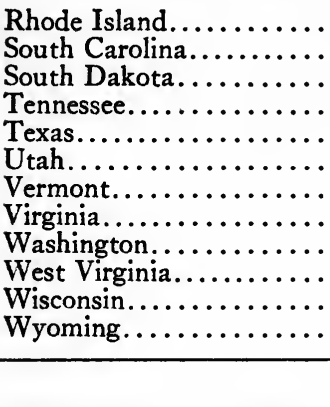 } & $\begin{array}{l}\cdots \cdots \\
\cdots \cdots \\
\cdots \cdots \\
\cdots \cdots \\
\cdots \cdots \\
\cdots \cdots \\
\cdots \cdots \\
\cdots \cdots \\
\cdots \cdots \\
\cdots \cdots \\
\cdots \cdots \\
\cdots \cdots\end{array}$ & 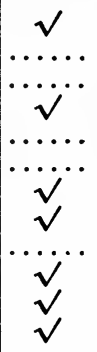 & $\begin{array}{l}\ldots \cdots \\
\cdots \cdots \\
\cdots \cdots \\
\cdots \cdots \\
\cdots \cdots \\
\cdots \cdots \\
\cdots \cdots \\
\cdots \\
\cdots \cdots \\
\cdots \cdots \\
\cdots \cdots \\
\cdots\end{array}$ & $\begin{array}{l}\mathcal{V} \\
V \\
V \\
V \\
V \\
V \\
\ldots\end{array}$ & $\begin{array}{l}\sqrt{ } \\
\sqrt{ } \\
\cdots \cdots \\
\sqrt{ } \\
\cdots \cdots \\
\cdots \cdots \\
\cdots \cdots \\
\mathfrak{V} \\
\sqrt{ } \\
\sqrt{ } \\
\cdots \cdots\end{array}$ \\
\hline & I & 21 & 16 & 42 & 27 \\
\hline
\end{tabular}




\section{PROBLEMS OF PRISON INDUS- TRIAL MANAGEMENT}

In the two preceding chapters we have set forth some of the general circumstances affecting prison employment, all of which must be kept in mind by anyone confronted with the task of setting prisoners to work. Rehearsing the list, we recall first that existing law determines many of the conditions of prison labor, such as the system or systems that can be used, hours of work, industries that can be selected, the percentage distribution as between different industries, the use or non-use of motor and electric power, and the necessity of marking the goods in some distinctive way. To the perplexed official charged with the employment of prisoners, the selection of systems, of industries, and of methods permitted by law must often seem a kind of Hobson's choice. The actual administrator must of course observe all the legal requirements, but he should not assume that they cannot be changed. The legal setting is frequently altered to the detriment of the prisoner, and it can likewise be changed to benefit him. 


\section{I26 SHOULD PRISONERS WORK?}

We also mentioned the type and location of prison plants, calling attention to the fact that often these in themselves offered serious obstacles to the successful employment of prisoners. It is our firm conviction that many changes in plant structure and equipment will have to be made before we can hope to see a majority of the inmates employed. Particularly is this so if a reasonable labor policy is to prevail in county and municipal jails. Undoubtedly they will in many instances have to be made to serve larger areas comprising several counties or, in thinly settled regions, the entire state. Here, too, is a task which only aroused public opinion can accomplish. An expert summoned in to diagnose the ills of an entire industry may decree the scrapping of some old plants and the construction of some entirely new ones, as did the engineer recently employed to advise the steel industry of Great Britain; just so, an expert on prison industry might and probably would find it necessary to scrap many an old prison plant and to construct others in order to devise a proper type of prison employment.

\section{Ordinary Economic Factors}

Under the contract or piece-price systems, nearly all phases of business management are cared for by the private parties making the contract. We are concerned not with their 
problems but with those which must be faced by officials charged with the organization and management of a state-account or state-use system. In spite of the fact that prison industry is carried on under circumstances quite different from those encountered in the free business world, the management must take into account all the ordinary economic factors such as climate, the availability of raw material, accessibility of markets, freight rates on material and finished product, size of capital outlay necessary, and labor supply.

1. Climate. We have already seen how climate accounts in part for the prevalence of road work in the South and for the huge prison farms on which men can be worked the year round. Outdoor work in northern prisons is limited by the climate, and therefore the efforts of trade unions and manufacturers to roll off on the farmers the burden of competing with prison labor cannot wholly succeed if prisoners are to be employed continuously. Supplementary industries will have to be provided for the winter months, a fact that immediately suggests the desirability of selecting industries which can be carried on seasonally or which can be easily expanded and contracted with little loss or difficulty.

2. Raw Material. With respect to the availability of raw material, it has been said that if 
the prison labor problem is to be solved, prisons will of necessity find themselves "making shoes where leather is plentiful, establishing cotton mills where cotton grows, manufacturing woolen fabrics where sheep graze, and furniture nearer the big forests. ..."1 Manifestly, the availability of raw material is only one consideration in the determination of what to produce, but lack of ordinary foresight in the selection of prison sites is not so uncommon as one might think. After much discussion of the desirability of employing prisoners in making bricks and in producing road material, a certain state selected for its new prison a site which proved to have neither suitable clay deposits nor stone available for road material. The Federal penitentiary at Atlanta, Georgia, manufactures cotton duck, a choice of industry undoubtedly dictated in part by the abundant supply of raw material. Alabama prisons raise cotton, spin and weave the cloth, and make shirts. So, too, the clay deposits of Ohio make it possible for the State Penitentiary to operate brick plants. Sing Sing, ${ }^{2}$ Folsom, ${ }^{3}$ and the Oklahoma State Reformatory ${ }^{4}$ at Granite all owe their locations at least in

${ }^{1}$ W. C. Wheeler, in American Prison Association, Proceedings (1928), p. 63 .

${ }^{2}$ Lewis E. Lawes, Life and Death in Sing Sing (New York, 1928), p. I9I.

${ }^{3}$ I929 Handbook, p. 145.

'Ibid., p. 777. 
part to the proximity of stone quarries, and two institutions (Brushy Mountain Penitentiary, Tennessee, and the Kansas State Penitentiary) are situated near coal mines.

But raw material has a broader meaning to prison authorities than it does to other producers. For example, an undeveloped or rundown farm would be raw material to a county jail or a state prison; so also would unconstructed buildings, although to be strictly logical we should perhaps discuss these under markets. The point that must be kept in mind is that prison authorities can no more disregard this question of the availability of raw material than can the free producer - in fact, owing to the difficulty of finding work for prisoners, the relation of site to raw material is of more importance to the prison than to the free plant.

3. Available Market. Market limitations greatly affect methods of production. Mass production demands the open market or at least a very large market. If a prison is catering to the state-use market, the number and size of its industries are directly influenced. It cannot go in for mass production of one specialized product without quickly oversupplying the limited stateuse demand. Former Governor Christianson of Minnesota well expressed this problem in discussing the Stillwater Prison: 


\section{I30 SHOULD PRISONERS WORK?}

We are engaged in the mass production of binder twine. If we are going to be compelled to withdraw largely from that field and dissipate the capacity of our prison by manufacturing furniture and shoes and shirts and overalls for the inmates of other institutions, we shall be forced to abandon mass production and get into small specialized and particularized production.

If we do that, we are going to be subject to the same limitations and handicaps that the small producer is in every other line. We shall be running our prison with a deficit rather than with a surplus, and we shall put this additional burden upon the taxpayers. ${ }^{1}$

Forced diversification by means of a percentage distribution between industries has the same effect as limiting the market by the state-use system. Small industries take the place of one large one and require the employment of several production managers, each skilled in a certain line. The sales problem also is greatly complicated. A single sales agent is not qualified to sell manifold products, and the individual enterprises may easily be too small to permit the employment of individual salesmen. In one of the Pennsylvania prisons, operating under the stateuse system, a shop foreman had to go on the road himself, as the regular sales agent was not able to explain satisfactorily the merits of all the goods he handled.

Moreover, mass production sells by means of low prices; limited production must sell

1 "Official Proceedings of the 1930 Governors' Conference," United States Daily, V (Supplement, July 14, 1930), 21. 
by means of quality. This implies skilled labor, but the majority of prisoners are not skilled:

"They are capable," says L. L. Emmerson, "of performing only . . . common labor. For instance, if they are manufacturing furniture, it must be of a very ordinary type. So it is with all of the things they produce. Hence, one cannot diversify [prison] employment .... as one might wish. [It is necessary] . . . to manufacture just those things that will sell on price rather than on merit."

While it is perfectly possible to train many prisoners to be skilled operatives, the process takes time, and the industrial superintendent cannot count on having trained men at his disposal, but must use as best he can the unskilled labor which comes to him. Mass production methods involving only easy operations will of course simplify the problem of training and tend to increase profits. So, if for any reason it is necessary to accept the limited market, we should be under no illusions as to the financial effects of this step: it means a less profitable prison labor plant.

4. Freight Rates. The matter of freight rates goes hand in hand with the availability of raw material and the accessibility of markets. The Colorado Board of Corrections stated in 1926 that it "had difficulty in finding industries in which the prison could compete, on account of the freight rates on raw materials shipped

\footnotetext{
1 Ibid., p. 23 .
} 


\section{I32 SHOULD PRISONERS WORK?}

into the state and on manufactured products shipped out." 1

5. Capital Outlay. The amount of justifiable capital outlay depends not only on the size of the market but on the size of the institution. Some types of machinery are much more expensive than others, and an industry must employ enough men to justify the investment. The tag shops now operating in many prisons employ comparatively few men, but the work is worth while for those few, the output fills a large state requirement, financial returns are reasonably large, and the size of the investment is not excessive. The Montana plant cost about $\$ 12,850$ to install, ${ }^{2}$ and employs from 25 to 55 men. ${ }^{3}$ The recently installed South Dakota tag plant was to cost $\$ 10,000$ and another $\$ 10,000$ was to be appropriated for a revolving fund. 4 The tag shop at the Connecticut Reformatory employed about 40 workers and did a business of $\$ 65,000$ in $1927-28 . .^{5}$ Twine plants, on the other hand, represent investments of $\$ 400,000$ or more, and machinery is a large part of this outlay. ${ }^{6}$

1 Prison Industries, p. 25.

2 Montana State Prison, 26th Biennial Report (I927-I928), p. 4.

${ }^{3}$ Ig29 Handbook, p. 548; Prison Industries, p. Io6.

- Board of Charities and Corrections, 20th Biennial Report (1927-28), p. 7.

${ }^{5}$ Report of the Directors (1927-28), p. 18; 1929 Handbook, p. I92.

6 Manufacturer's statement, Conoict Labor in 1923, p. I3I. 
Diversification increases the capital outlay for machinery. It is necessarily more expensive to install three or four sets of equipment requiring a given number of men than one set engaging the same number. Also, overhead expense is increased with diversification, though H. B. Gill estimates that this increase is not directly proportional to the amount of diversification. ${ }^{1}$

Another investment item which is receiving increasing attention is the provision for good working conditions. Prison shops in the past have too of ten been dark, unventilated, crowded, and generally insanitary. State authorities have broken their own laws regulating such matters, as well as the laws requiring safety devices on dangerous machinery. ${ }^{2}$ Most states now realize that their prison shops must conform to the law, and that healthful surroundings are vitally important to the welfare of prisoners. In prison as well as out, good conditions are also an aid in securing efficient production.

\section{Selling the Products}

Nor is it enough to make goods properly and well; they must be sold. In private business the sales end is just as important as the produc-

\footnotetext{
${ }^{1}$ Testimony before the New York State Crime Commission, MS stenographic report of proceedings, November 21, 1929, p. I403.

2 [New York] Prison Survey Committee, Report (1920), pp. 37, 163; 1929 Handbook, pp. 162, 263, 359, 383, 536, 678, etc.; J. B. Andrews, "Workmen's Compensation for Convicts," American Labor Legislation Review, XV (I925), I33.
} 


\section{I34 SHOULD PRISONERS WORK?}

tion division. Not all officials in charge of prison industries realize that to keep the finished goods moving they must develop a sales force that can get orders. We read that:

Advertising in most prison industries is limited to the publication of catalogues or price lists of prison products, and in some prisons such a list represents the total sales effort. ${ }^{1}$

Paul W. Garrett corroborates this statement for New York:

If there has ever been any real selling organization to dispose of the product of the New York state prisons, other than a price list mailed from time to time to city and county purchasing departments, I have not been able to find it out. ${ }^{2}$

The purchasing agent of an important state complained recently to the writer that the prison labor people were not well informed as to what was needed by the state. They did not anticipate demand as did private business men and often lost opportunities which were grabbed by private salesmen. Some states, however, do see the close connection between selling goods and keeping the prisoners employed:

The prison farm-machinery plant at Stillwater, Minn., maintains a corps of field men to sell and to give service to purchasers. These men are frequently used to address

1 Prison Industries, p. 14.

2 Testimony before the New York State Crime Commission, November 22, 1929, MS stenographic report of proceedings, p. 1467; as corrected by letter of August II, I93I. 
meetings of farmers to explain the prison industrial program. ${ }^{1}$

A recent observer reports that Stillwater now has eighteen men in the field. ${ }^{2}$ Michigan also has developed its prison sales organization quite effectively. The Massachusetts Deputy Commissioner of Correction in charge of industries maintains no sales force, but keeps in touch with the various purchasing agents by means of letters, sales catalogs, and form advertising; he checks up on new construction projects by means of F. W. Dodge reports. Nor does he hesitate to refuse to sign releases without good cause and to have violators prosecuted by the Attorney General. ${ }^{3}$ The Connecticut Reformatory increased its printing orders by having one of its officers visit the various state departments once a week to get a good knowledge of requirements. ${ }^{4}$

Energetic sales work, either by means of a field force or through an alert central office, is obviously necessary, even under a good stateuse law like the Massachusetts one. It is foolish to assume that the compulsory-purchase clause will always produce sufficient orders. Under the state-account system, attention to sales is

\footnotetext{
1 Prison Industries, p. I4.

2 Letter from Mr. E. R. Cass, July I, I93I.

${ }^{3}$ E. C. R. Bagley, testimony before New York State Crime Commission, November 21, 1929; MS stenographic report of proceedings, pp. I328, I331, I337, I339.

Report of the Directors (1927-28), p. 7.
} 


\section{I36 SHOULD PRISONERS WORK?}

doubly necessary, for outside competition is keen, unceasing, and well financed.

\section{The Labor Supply}

But prison industry is not a matter of setting out to make a profit in a likely looking field, taking advantage of climate, raw material, markets, and freight rates. For the prison administrator, it means being presented with an arbitrarily chosen group of workers and told to keep them employed according to their needswith a profit, preferably, yet at the same time without stepping on the toes of free industry. All important to him, then, is the labor supply.

The nature of his labor force is peculiar. It is static in that it cannot depart of its own free will and cannot be discharged for any reason; nor can its number be increased according to production needs. Yet the turnover is arbitrary and has no relation to wages, working conditions, or performance of work. Indeed, where the indeterminate sentence is in full use, as at Napanoch, the ordinary connection between labor turnover and performance of work is just reversed: a prison worker is not only not discharged for poor work, but held until he learns how to do good work, and then released (other conditions being fulfilled). The prison gets and must take all types regardless of their fitness for work. And if wages or conditions do not suit 
the worker, strikes are ineffective, as he can be legally compelled to work; but he can and often does loaf on the job and will sometimes sabotage machinery. It should be noted, too, that the well-trained, capable, efficient man does not usually get into prison. Oscar Lee, the experienced warden of Wisconsin State Prison, raises this question:

Just how well trained is the average prisoner? We often say that we can pick from our inmate population men to do almost any kind of work. It is true, we can, but as a rule these men are not well trained. They are not the artists in their lines whom you would employ in your business. To the contrary, they are usually careless, slipshod and indifferent, and their work must be constantly watched, supervised, and corrected. ${ }^{1}$

Taking the prison population as a whole, it is apparent to even the casual observer that there is a goodly percentage of men whom no sane employer would hire on any terms. To begin with, there are the feeble-minded, the insane, and the indigent similar in all respects to inmates of an almshouse. There are those who have never been taught how to work and those who will not work if they can possibly avoid it. There are the stupidly ignorant and the too knowing. There are likewise men with twisted and warped personalities which have undoubtedly prevented them from holding positions in the free world of industry.

\footnotetext{
1 American Prison Association, Proceedings (1928), pp. 354-5.
} 


\section{I38 SHOULD PRISONERS WORK?}

\section{Classification Studies}

For the intelligent planning of prison industries, the first requisite is a survey of the inmate population from the particular angle of work possibilities. Very few such surveys have been made, a lamentable fact from both the business and the educational points of view. Comprehensive studies of a state's entire prison population for any reason at all are rare, although classification of inmates by individual institutions is less unusual and the segregation of the insane is common practice. The Wisconsin State Prison makes use of psychiatry in determining work assignments. ${ }^{1}$ The Federal Industrial Institution for Women at Alderson and the women's reformatories in Connecticut, Massachusetts, New Jersey, and Pennsylvania all use scientific classification in handling their charges. Pennsylvania is in process of constructing its Cumberland Valley institution for male mental defectives. Massachusetts segregates defectives on the state farm at Bridgewater and maintains psychiatrists at Charlestown and Concord; the Department of Correction exercises wide powers of transfer among the institutions under its control, thus effecting a rough and surprisingly helpful classification. New York has its pioneer Institution for Defective Delinquents at Napanoch and there is a section for defectives

${ }^{1}$ Ig29 Handbook, p. Ioo3. 
in the Women's Reformatory at Bedford Hills; Elmira Reformatory uses psychiatry and attempts classification, determining work assignments by tests; ${ }^{1}$ Auburn Prison has the benefit of "limited psychiatric service." ${ }^{2}$ The facilities of the psychiatric clinic at Sing Sing are unrivaled in the country and it is planned to make the prison a receiving and classification station for the state's eastern penal institutions. The Commission to Investigate Prison Administration and Construction recommended that a receiving clinic for the western half of the state be established at the new Attica prison. ${ }^{3}$ The present Sing Sing clinic commenced operation in 1927 and has gradually increased the extent of its work until it now examines as a matter of routine every man admitted to the prison. ${ }^{4}$ Routine examinations of all prisoners entering Federal institutions have recently been undertaken, to lay the foundation for proper segregation of types. ${ }^{5}$ When the new Federal institution for defectives is built, the Bureau of Prisons will be in a better position to act upon the results of its pyschiatric, psychological, and medical findings, which are to be checked with carefully obtained case histories.

\footnotetext{
1 Ibid., p. 687.

${ }^{2}$ Commission to Investigate Prison Administration and Construction, Preliminary Report (1930), p. 22.

${ }^{8}$ Report (I93I), p. IO.

Letter from Lewis E. Lawes, December 5, 1930; Prison Association of New York, 83rd Annual Report (1927), p. 22.

5 Letter from A. H. MacCormick, July Io, I93I.
} 


\section{I40 SHOULD PRISONERS WORK?}

General classification studies of prisoners divide into two types - those made by psychiatrists and psychologists very largely for purely scientific purposes and those undertaken for practical administrative reasons. ${ }^{1}$ Psychiatrists and psychologists are interested primarily in discovering how many of the prison group are mentally normal (whatever the particular definition of that blanket term), how many are emotionally disturbed, how many below average intelligence, how many insane, alcoholic, epileptic, addicted to drugs - and so on. Prison administrators want rather to know how many need close confinement, how many can be trusted on farms and in similar "open" institutions, how many must be hospitalized, how many segregated for behavior or mental reasons, and also how many will be available for various industries. Psychological, psychiatric, social, and medical findings are for the administrator tools, not ends in themselves, and are useless in his eyes unless applied to problems such as type of construction needed, kind of industry to be installed, and types of academic, therapeutic, and trade instruction required. The classification worked out by a committee of the American Prison Association attempts to steer a middle course between strictly scientific mental and person-

${ }^{1} \mathrm{~A}$ recent symposium on classification problems is reported in Classification of Prisoners (National Committee on Prisoners and Prison Labor, I93I). 
ality groupings and the rougher outlines of administrative groupings, ${ }^{1}$ with the result that its classification scheme is open to some criticism from psychiatrists. ${ }^{2}$

1. The New York Classification Scheme. The Commission appointed by Governor Roosevelt in I930 to study New York's problems of penal administration and construction found it necessary to obtain a classification of all state prisoners before proceeding to make any estimate of construction and personnel needs. (No jails or other institutions for short-term prisoners were included in the scope of the Commission's work.) This study is divided into two parts, the psychiatric and the administrative, and "a double classification is utilized on each prison inmate so as to secure the two-fold grouping. . . . This double procedure is necessary because the factors in the psychiatric-diagnostic grouping ... and those of administration ... are mutually exclusive." 3 Intelligence ratings are given in supplementary form. A comparison of the two groupings will show overlapping and lack of correspondence, revealing the fact that psychiatric studies do not in themselves constitute a workable classification for administrative purposes, but that they do form the basis, the point

1 Prison Association of New York, 85th Annual Report (1929), p. 22.

2 V. C. Branham, "The Classification of the Prison Inmates of New York State," in Commission to Investigate Prison Administration and Construction, Supplemental Report, pp. 24-7.

${ }^{3}$ Ibid., p. I. 


\section{I42 SHOULD PRISONERS WORK?}

\section{of departure, from which administrative classi- fications may be built up:}

\section{TABLE XIII}

Classification of Types-New York State Prisoners

\section{Administrative Classification*}

I. Colony Group (to be housed in minimum and medium security prisons, i.e., road camps, farms, "open" prisons).

Young occasional offenders who have served half their time.

Inmates with good conduct records and short time left to serve.

Middle-aged inmates who have served considerable time and show signs of stabilization, and who also have good homes waiting for them.

Inmates of proven responsibility; accidental offenders.

Stable, high-grade feeble-minded cases which have been well studied.

2. Restricted Group (to be housed in "maximum security" cellular walled prisons).

(a) Temporary:

All new admissions.

All inmates up to half the sentence.

Young occasional offenders

(b) Prolonged: especially.

Lifers and other long termers.

Those with warrants pending.

Troublesome types (except psychopathic).

Inmates guilty of vicious assaults (e.g., murder)and of inciting riots.
Psychiatric Classification $\dagger$

(American Prison Association's scheme used with reservations.)

I. Normal:

All those not otherwise classified.

Intelligent, stable offenders without long criminal history. Border-line intelligence cases.

\footnotetext{
* Branham, "The Classification of the Prison Inmates of New York State," pp. 5-8.

† Ibid., pp. 39-45.
} 


\section{PROBLEMS OF MANAGEMENT I43}

TABLE XIII (Continued)

\section{Administrative Classification}

3. Psychiatric Group (to be housed in special unit, except for out-patients).

(a) Extensive treatment group: Inmates with marked mental upsets.

Some to be transferred to insane group.

(b) Observation group.

(c) Out-patient group.

Inmates in other groups but requiring some psychiatric care.

4. Hospital Group (to be housed temporarily in walled prison hospital units).

(a) Those physically ill.

(b) Aged and incapacitated.

(c) Tubercular cases.

5. Defective Delinquents (to be housed in separate unit).

Low-grade feeble-minded delinquents.

Higher-grade, feeble-minded, unstable cases.

Recidivists who have deteriorated mentally.

6. Insane Delinquents (to be housed in hospital for insane criminals).

\section{Psychiatric Classification}

3. Neuropathic (abnormal but not insane):

Psychopathic personalities.

Epileptics.

Post-encephalitic personalities.

Alcoholics.

Drug addicts.

Psychoneurotics.

Other abnormal cases.

\section{Feeble-minded:}

Low-grade, feeble-minded, emotionally stable recidivist.

High-grade, feeble-minded, emotionally unstable inmate.

Epileptic with marked mental deterioration.

Psychopaths of low intelligence.

4. Psychotic (insane).

\section{Potentially Psychotic:}

Cases recovered from psychosis. Cases partially recovered.

Cases showing physical symptoms of incipient psychosis.

Intent on devising a feasible work program, we are here concerned only with the results obtained from the administrative classification, which was devised by Dr. Amos Baker of the Sing Sing clinic and Dr. V. C. Branham, Deputy Commissioner of Correction. Figures apply to 


\section{I44 SHOULD PRISONERS WORK?}

the fall of 1930. The 8,474 men then in the four state prisons, the reformatory, and the Institution for Defective Delinquents fall into the following percentage groups:

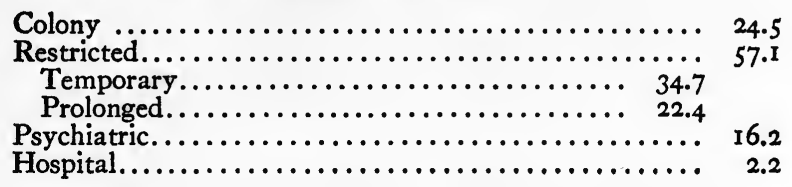

All insane delinquents, presumably, are already in Dannemora and Matteawan State Hospitals, as they do not affect these percentages, but Napanoch's defective delinquents are distributed under the headings just listed and the majority of them fall within the restricted class (54.7 per cent temporary, 33 per cent prolonged). ${ }^{1} \quad$ The 460 inmates of the Women's Prison at Auburn and the Bedford Reformatory are separately classed ${ }^{2}$ in the same manner:

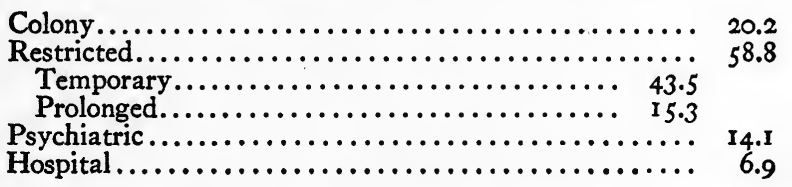

The Albion State Training School was not included in this administrative classification because psychiatric studies had previously been made and it was apparently not necessary to duplicate the work. ${ }^{3}$

\footnotetext{
1 Branham, op. cit., p. 17.

2 Ibid., p. 20.

8 Ibid., p. II.
} 
We must constantly bear in mind that jail and other misdemeanant prisoners are not included in any of the figures just given.

Before proceeding to comment on the industrial implications of these findings, let us compare the New York classification scheme with a different grouping of types worked out in New Jersey.

2. The New Jersey Classification Scheme. No state has gone so far as New Jersey in devising and using classification to solve administrative problems and to further the underlying purpose of bettering theindividual prisoner's condition and outlook. For twelve or fourteen years the state has done excellent work in studying and classifying the population of state (not county or municipal) prisons, having in mind a broad program of work, education, training, and treatment, with special reference to industrial needs. The methods employed are worth close consideration.

The routine procedure involves detailed examination of each newly received prisoner by each of the following staff officers: the identification officer, disciplinary officer, physician, psychiatrist, psychologist, chaplain, director of education, director of industries and training, social investigator (field worker). The results of these different studies are correlated at a staff classification meeting and recommendations made for the assignment and treatment of the individual. 


\section{I46 SHOULD PRISONERS WORK?}

Transfer to another institution may be recommended. Periodic reclassification takes care of any changes in the prisoner's physical or mental condition and fresh examinations are made whenever a case gives trouble or fails to adjust well. ${ }^{1}$ The State Prison at Trenton and the State Reformatory for Women at Clinton serve as general receiving and classification stations, but every institution in the correctional system uses the procedure just outlined. The scope of the plan is necessarily wide:

The Classification System as carried out in the State's penal and correctional institutions necessitated 5,550 mental examinations during the fiscal year $1929-1930 \ldots$

Of the total 5,550 examinations, 2,I 17 were on individuals newly admitted to the institutions; 584 were made to determine the suitability of cases for parole; 58I persons who were not adjusting properly to their work or school assignments were reëxamined to determine the cause of their difficulty; and 204 examinations were made of persons of correctional institutions who had been paroled. Other examinations were made at the special request of institutional officers, because of disciplinary problems and to determine the suitability of transfer to another institution.

In accordance with the ... system ...., I05 transfers were made from the State Prison at Trenton to the State Reformatory at Rahway, the Prison Farm at Leesburg, and the Prison Farm at Bordentown, during the month of August [1930].2

1 William J. Ellis, "Classification as the Basis for Rehabilitation of Prisoners," National Society of Penal Information, Neros Bulletin, II, No. I (February 1931), 7-9.

2 National Society of Penal Information, News Bulletin, I, No. 4 (October 1930), 4 . 
The original classification grouping worked out by Dr. Edgar A. Doll has undergone some modifications; the present form has been discussed recently by both Commissioner Ellis and Dr. Potter of the Department of Institutions and Agencies, and from their published addresses ${ }^{1}$ we have taken the following descriptive outline of prisoner types:

\section{TABLE XIV}

Classification of Types-New Jersey State Prisoners

I. Difficult Class:

Recidivists with bad records, often psychopathic.

Antisocial cases: dealers in drugs, liquor, and firearms within the prison; rioters and agitators.

Psychopaths of good intelligence.

2. Better Class:

Those without marked mental or physical defects or hostile attitude.

(a) Long termers requiring close custody for that reason, but who should be separated from difficult class; suitable for industries.

(b) Short termers, suitable for farm colonies.

(c) Young intelligent offenders, fit for vocational training.

3. Feeble-minded Class:

Border-line cases........

$\left.\begin{array}{l}\text { Morons................. } \\ \text { High-grade imbeciles..... }\end{array}\right\}$ without psychopathic complications.

4. Incapacitated Class:

Cripples.

Aged and infirm cases.

Cases suffering from chronic diseases.

5. Psychotic and Epileptic Classes:

Insane cases.

Epileptics.

6. Defective Delinquent Class:

Cases of subnormal mentality coupled with mental instabilityi.e., low intelligence plus psychopathic disorders.

${ }^{1}$ William J. Ellis, op. cit., pp. 6-7; Ellen C. Potter, "The Influence of the Mental Hygiene Movement on Correctional Institutions," Prison fournal, XI, No. I (January I93I), 2. 


\section{I48 SHOULD PRISONERS WORK?}

A study of over two thousand commitments during "the last three years" 1 has yielded the following percentages:

1. Difficult Class...................................... 35.5

2. Better Class.............................. 50.9

3. Feeble-minded $\ldots \ldots \ldots \ldots \ldots \ldots \ldots \ldots \ldots \ldots \ldots$ 10.5

4. Incapacitated...........................

5. Psychotic and Epileptic.................... 1.4

Like the New York administrative scheme, the New Jersey classification is based in part on psychiatric and psychological findings and in part on practical experience - a combination made for administrative purposes. The two are not dissimilar, as a condensed comparison (Table $\mathrm{XV}$, page I49) will show.

The Right Job for Each Prisoner

Taken together, the two outlines help us to see what a scientifically arranged work program would look like. The insane (New Jersey 5 , New York 6) should be placed in hospitals and given therapeutic work. Connecticut found it possible to do this within the prison walls; insane prisoners there were reported to "show enthusiasm and industry in the making of marketable rugs and brooms. Several ... [were] restored to mental balance by the employment process." 2 Occupational therapy is a vital part of the régime at the Indiana Hospital for Insane Criminals,

1 The period from I 928 through I930, presumably; cf. Potter, loc. ctt.

2 State Prison, Report of the Directors (1925-26), p. 8. 


\section{PROBLEMS OF MANAGEMENT I49}

\section{TABLE XV}

\section{Comparisons of Classifications}

New Jersey

I. Difficult Class:

Recidivists, trouble makers, etc., including high-grade psychopaths.

2. Better Class:

(a) "Normal" long termers.

(b) "Normal" short termers.

(c) Young, intelligent amenable offenders.

3. Feeble-minded Class:

Cases of low mentality without psychopathic complications.

4. Incapacitated Class:

Cripples, aged and infirm, cases with chronic diseases.

5. Psychotic and Epileptic Class.

6. Defective Delinquent Class:

Low-grade unstable cases, i.e., psychopathic.
NEW YoRK

2. Restricted Group:

(a) Temporary:

New admissions, etc.

(b) Prolonged:

Long termers, trouble makers, etc. - except psychopaths.

1. Colony Group:

Young occasional offenders; those with good conduct records and short terms remaining; responsible cases; stable high-grade feebleminded cases.

5. Defective Delinquent Group:

Low-grade feeble-minded cases; higher-grade feebleminded unstable cases; mentally deteriorated recidivists.

4. Hospital Group:

Tubercular cases and others physically ill; aged and incapacitated.

6. Insane Delinquent Group.

3. Psychiatric Group:

Cases of marked mental disturbance bordering on the insane, and all other mentally abnormal cases.

(a) Extensive treatment.

(b) Observation.

(c) Out-patient.

which is separated from the Indiana State Prison but is under the same management. ${ }^{1}$

Only the incapacitated (New Jersey 4, New York 4) and inmates under extensive psychiatric

1 Indiana Hospital for Insane Criminals (Michigan City, n.d.), pp. 8 ff. 


\section{SHOULD PRISONERS WORK?}

treatment (New York 3a) can be dismissed from the list of those needing regular, full-sized jobs. The aged and infirm are at most fit for only the simplest kind of maintenance job, and it is cruel to expect more from them; the line dividing them from almshouse inmates is very faint; simple tasks about a farm prison, in the open with little restraint, would fill their time and relieve the community of the burden of caring for them.

The mentally subnormal group (feeble-minded, New Jersey 3; defective delinquents, New York 5) 1 must have "occupational" work - something to keep them healthily busy, but demanding no more than their mental capabilities permit; it need not have vocational value if they are to be detained permanently. That is, vocational training may be limited to fitting a man into his niche in the restricted prison régime, while those who will be able to reënter the free world should receive more intensive occupational training. Napanoch's experience shows that subnormal types can be used at productive work and that a certain per cent can profit by instruction and a knowledge of the particular job

1 The subnormal group is the type for which Napanoch is primarily intended; those whom Dr. Doll and Commissioner Ellis label defective delinquents would be called unstable or psychopathic by Dr. Branham and Commissioner Thayer of New York. The terms are not defined accurately or used carefully in current penological discussions. The essential difference we are trying to make is between subnormality (intellectual defect, low intelligence) and abnormality (personality or 
which fits the individual's mental make-up. Dr. Walter N. Thayer, Jr., Commissioner of Correction for New York State and former Superintendent of the Institution for Defective Delinquents, gives the following summary of industrial work at Napanoch:

Besides operating its utilities, such as kitchen, mess hall, laundry, farm, etc., we manufactured and repaired all of the shoes worn by the inmates, did the cobbling for a number of other institutions, manufactured clothing, socks, mittens, caps, rugs, mattresses, toweling, baskets, hampers, brooms, sheet-metal ware and aluminum ware. Some of these articles were for sale under the state-use system. There were classes in blacksmithing, carpentry, painting, masonry and concrete block making. In addition, we had a small print shop and operated a dairy farm ...., with a herd of from 40 to 60 head. A considerable amount of macadamized road was constructed and some forestation work was done. All barbering, haircutting, etc., were performed by inmates. ${ }^{1}$

This list of jobs is more comprehensive than one might expect, and includes some skilled operations. It indicates not that subnormal individuals are incapable of performing shop work that is easy for the normal prisoner, but that

\footnotetext{
emotional defect or disorder, psychiatric instabilities). Thayer defines a defective delinquent as "that offending member of society who upon examination shows an appreciable limitation of responsibility due to mental deficiency ...; i.e., the lack of capacity in an individual to derstand what is perceived by others, the lack of capacity to be able to act in such a manner as to achieve what one is striving for, and the lack of capacity to make correct combinations of new material ..." Institution for Defective Delinquents, 5 th Annual Report of the Boord of Managers (I927), p. II. p. 8.

1 "Institutions for Defective Delinquents," Penal Affairs (May 1930),
} 


\section{I52 SHOULD PRISONERS WORK?}

the subnormal man cannot keep the pace set in the ordinary shop and that he needs training fitted to his needs. It is the homogeneity of the group which counts even more than the intelligence level, in any course of work or training. ${ }^{1}$ To quote Thayer again:

All individuals below the grade of high-grade imbecile should, if a social problem, be cared for in one of the state schools for defectives. On the other hand, individuals higher in intelligence than the moron group will adjust better in correctional institutions than in institutions for the defective [i.e., subnormal, feeble-minded], and should be so placed.2

Another phase of the problem is to keep an institution for this subnormal, underdeveloped type free from the upsetting influence of the abnormal individual, the psychopath, the man with dominant personality defects and emotional instability as differentiated from intellectual deficiency.

Psychopathic individuals (defective delinquents, New Jersey 6, also I; psychiatric group, New York 3) are particularly difficult to deal with. Much or little may be done with them industrially according to conditions in each case. No general plan can be laid down. As a matter of fact, science has not yet indicated clearly how they should be handled. The correctional institutions believe that they constitute a medical

'Thayer, "Six Years' Experience with the Defective Delinquent," Penal Affairs (January I928), p. II.

I Ibid. 
problem and should be so treated. Speaking of women psychopaths, Mrs. Jessie D. Hodder of the Massachusetts Reformatory for Women declared in 1920:

They force upon the reformatory régime a problem all their own - it is not a reform problem. We have not found to what treatment they are accessible in a reformatory - meaning by treatment, educational and correctional discipline. When we called in, in consultation, a group of psychiatrists ... they declared they had nothing in their profession available and suggested rigorous correctional discipline. But we had learned that correctional discipline did not change the emotional tone of these women, and it intensified their outbursts. We were also convinced that residence in a reformatory aggravated their disease. However, these experts would not accept our patient on a transfer to their institution to work out a method of treatment for her. ${ }^{1}$

More recently, another experienced superintendent, Miss Florence Monahan of the Minnesota State Reformatory for Women, emphasized the problems involving the psychopath:

As in any institution of this kind, all of the disciplinary problems are caused by a small group, probably not more than $20 \%$ of the population. These are often lead [sic] by abnormal or psychopathic personalities who have a few imitators amongst the women. If it were possible to segregate this group, very little restraint or discipline would be needed for the rest. This small group because of its activities secures the greatest portion of the time and attention of the officers and yet in results obtained here, or [on] the outside, they are least hopeful and most

1 "Disciplinary Measures in the Management of the Psychopathic Delinquent Woman," National Conference of Social Work, Proceedings (1920), p. 395 . 


\section{I54 SHOULD PRISONERS WORK?}

worthless. They are of different ages and experiences so that it is impossible to put them all in one cottage. It is impossible also because no ordinary officer could cope with the whole group together. They need special psychiatric treatment, which is not provided in an institution of this kind.1

Hospitals, Mrs. Hodder points out, are loath to take this class of patients, insisting that they belong in correctional institutions. They are not wanted in institutions intended, like Napanoch, for subnormal defectives. They are equally undesirable in a prison for mentally normal persons. The rough-and-ready prison administrator, secure in the belief that force and dark cells suffice, usually scoffs at all efforts to find a scientific solution of the difficulty. He once believed this about the insane, and we shall no doubt look back upon his answer to the problem of dealing with psychopaths as we do on his past attitude toward the insane. The time will probably come when psychopathic individuals will be properly segregated, and work will be provided in accordance with a scientific plan of treatment. Says Dr. Doll:

The industries of this type of institution should be of the occupational therapy and shop type especially designed to meet the mental limitations and correctional needs of the inmates. The administration of such an institution should be exceptionally capable, since this is perhaps the most difficult class of prisoners with which to deal, and

${ }^{1}$ Fourth Biennial Report (1927-28), p. 6. 


\section{PROBLEMS OF MANAGEMENT I 55}

unless sympathetically managed their correctional treatment is nearly hopeless. 1

But Dr. Bernard Glueck, who began the psychiatric study of Sing Sing prisoners, declared that the psychopathic group showed promise "from a therapeutic point of view." 2

Dr. Branham's report on classification for New York stresses the need for a unit devoted to special psychiatric study and treatment, ${ }^{3}$ and some such center for intensive study is badly needed in order to discover just how psychopathic prisoners may best be handled.

From the employment point of view, the "difficult" group (New Jersey I) is not homogeneous. The psychopaths, as just pointed out, need separate treatment, while recidivists and "trouble makers" may vary enormously in work capabilities. The subdivisions of the New York "restricted" group offer a somewhat clearer classification. Recognizing the fact that Class I (New Jersey) and Class 2b (New York) may be inefficient and difficult to direct, we must nevertheless assume that on them and on the members of the most promising group in each classification will rest the major prison industries.

\footnotetext{
1 "Some Principles of Correctional Treatment," Fournal of Criminal Law and Criminology, XVIII (August 1927), 204.

2 Concerning Prisoners (New York: National Committee for Mental Hygiene; reprint from Mental Hygiene, Vol. II, April 1918), p. 30.

${ }^{3}$ Op. cit., p. 7 .
} 


\section{I56 SHOULD PRISONERS WORK?}

The promising cases (New Jersey 2, New York I and, in part, 2a) comprised about 50 per cent of 2,000 commitments in New Jersey and nearly 60 per cent of 8,474 prisoners in New York's custody in the fall of 1930. They are on the whole adaptable to a wide variety of employment and need no special consideration from a therapeutic standpoint. But they must have plenty of shop, farm, and road work. Included among them are the individuals able to profit by vocational training. All the resources of farms, construction camps, productive industries, and maintenance shops must be utilized if the various individuals are to be properly assigned so that the different labor units will function efficiently. Dr. Branham points out that, in a system by which men are graduated from walled to open institutions, adequate work provision must be kept continuously in mind:

Of the 2900 inmates in the temporarily restricted groups [New York 2a] many will become skilled in the use of machinery. When they progress to the colony units, industries of a specialized nature should be awaiting them. ${ }^{1}$

\section{Vocational Training}

In the light of these two important classification studies the outlines of a proper prison labor system begin to appear. A detailed study of the inmate population from the viewpoint of work possibilities is plainly the first requisite. As

1 Op. cit., p. 2. 


\section{PROBLEMS OF MANAGEMENT I 57}

penologists we are not, however, in terested solely in what men can do on the basis of present skill, but also in what they could accomplish with further training, so that a secondary requirement is to discover the prisoners' vocational possibilities, which are by no means identical with work possibilities. What can and cannot be done in providing trade training for prisoners depends first of all upon the proportion able to profit by such teaching. We have seen one careful estimate of the types of human material available for this purpose in institutions housing long-term prisoners:

TABLE XVI

Vocational Possibilities: i, 5 I5 New York Prisoners

Percentage

Technical ability............................ 20

Teachable...................................... 20

Machines only................................... 40

Incapable..................................... 20

100

The New York Prison Survey Committee in I920 devoted a chapter of its report to the subject of vocational training and the above estimate is based on data obtained from $\mathrm{I}, 5 \mathrm{I} 5$ cases specifically studied for the purpose, in four state prisons. ${ }^{1}$ By way of comment, the Prison Survey Committee said:

The majority of the investigators went into the prison with the idea that all men are capable of reform and that all desire to reform; that all men need vocational training

${ }^{1}$ Report (1920), pp. 166-7. 


\section{I58 SHOULD PRISONERS WORK?}

and by getting it intend to live honest lives; and that every man, when given a chance, will make good. But after going through the prison and talking with over $\mathrm{I}, 500$ men in securing educational and vocational data, these investigators realized that the prison problem is a very complex one. ... 1

... the conclusion is reached that approximately 40 per cent of the total prison population is capable of vocational rehabilitation through vocational training of the order which requires ability to comprehend industrial processes and ability to express such comprehension in skilled hand work or machine work requiring some skill.

From the ... data it is clear that it is not at all easy for a prison to make every inmate, through vocational training, into a skilled mechanic. .. The State should expect to accomplish a great deal vocationally with 40 per cent. It will try to do something vocationally with another 40 per cent. Probably it can never do much with the remaining 20 per cent. ${ }^{2}$

Whether or not the percentages given would hold for every state or whether they are anything more than approximately correct for any one state, it seems reasonably certain that the nature of the prison population imposes severe limitations on vocational training - a fact which has not been recognized by labor spokesmen who advocate trade training for prisoners as a means of cutting down production and competition, ${ }^{3}$ nor by garment manufacturers who show an interest in vocational training when they think

1 Survey Committee, Report (1920), p. 163.

2 Ibid., p. 177.

- Cf. John P. Frey, "The Trade Union Attitude Towards Prison Labor," Annals, XLVI (March 1913), 132-7; Edward F. McGrady, in Report of Proceedings of National Conference on Reduction of Crime, p. IO8. 


\section{PROBLEMS OF MANAGEMENT 159}

their own industries will not be suitable for the purpose. ${ }^{1}$ Some of the views expressed on vocational training are entirely too optimistic and too prone to overlook the hard facts of the situation. For example, the American Prison Association's Committee on Prison Administration reported in I92I that "a penal institution should be a vocational school primarily," also that "those industries should be selected and established which will give the greatest possible vocational training to the inmates." 2 The superintendent of the Minnesota State Reformatory spoke of "the modern view that the penal institution should lay emphasis on the vocational side of its industrial work, and that the industries shall contribute to the formation of character through training in trades. ..." 3 At the 1926 meeting of the Association, the principle that prisoners should be employed at "productive work which has vocational value" was mentioned as an important development. ${ }^{4}$ These statements are all good propaganda and useful in the campaign to effect an improvement in the employment of prisoners, but we should banish from our minds once for all the idea that in a well-conducted prison every inmate would learn a skilled trade to carry on when released.

1 Cf. Convict Labor in 1923, pp. 113, 124.

2 Proceedings (I 921), pp. $265,267$.

3 Ibid., p. 312.

4 Proceedings (I926), p. 77. 
Many administrators believe that it is the work habit which counts and which the men must acquire, rather than skilled trade training. Thus when the authors of the I929 Handbook criticized the shirt industry at the Idaho State Penitentiary, the warden's reply was typical of this attitude:

"Regarding the shirt factory, which you claim has almost no vocational training value for men, permit to say [sic] that you have overlooked the major phase of the question, and that is that the factory inculcates the good habit of work, and starts the idle youth on the right path and makes him understand the dignity of honest labor."1

Warden Oscar Lee of Wisconsin says:

Our greatest attention, our most earnest efforts should be concentrated on the untrained, the careless, the indifferent. Such men must be taught that only the best work, only their best efforts will be accepted. It matters not what the work, it may be making shirts or building a house, it may be baking bread or firing a furnace, whatever the job, careless, slovenly work should not be tolerated. It is often due to just such work that men finally land in prison. Employers of labor will not, can not tolerate work of that kind, and any man who expects to hold a job today must do a[n] honest day's work and do it well. If he has not been trained to do so before he enters prison, he should be so trained when he leaves. ..

We talk about teaching and training men in prisons. The greatest lesson any man can learn is that if he would eat he must work, if he would enjoy the good things of life, he must earn them by honest labor, by the sweat of his brow if necessary. ${ }^{2}$

1 P. 254 .

2 American Prison Association, Proceedings (I 928), pp. 354, 355. 


\section{PROBLEMS OF MANAGEMENT I6I}

Mr. Gill puts the case in even stronger terms. In speaking before the New York State Crime Commission, he made the following statement:

You have got 40 per cent, possibly, who are laborers and factory hands. I don't think it makes very much difference whether these men work at knitting undershirts or sewing work shirts or making shoes. I am frank to say that I don't lose much sleep over those inmates who work in women's industries. The main thing is those men are going to work at machines - that 40 per cent are going to work at machines in some factory somewhere, and it doesn't make very much difference to them what machines they work at. They acquire the habit of industrial work-eight hours steady every day, six days a week, fifty-two weeks a year. They will get machine-minded, and that is about all they are capable of. 1

Superintendent George C. Erskine of the Connecticut Reformatory speaks of the matter with the authority of long experience in institutional work:

We have in the Connecticut Reformatory as good commercial trade schools as there are in any of the penal institutions, and they will compare favorably with the trade schools in the public school system. There are those who cannot be trained for skilled trade, workers who never could become journeymen. I speak of this, knowing considerable about it, having served time as a mechanic, and I have been in charge of outside shops where the production had to be for the purpose of making money.

${ }^{1}$ MS stenographic report of proceedings, p. I389. "It is, of course, true that it would be more satisfactory if these men could work at some machine which they would work at on release; but is is not nearly so important with this group as many people think who imagine that all inmates are capable of and anxious for vocational training." (Letter from Mr. Gill, August 7, 1931.) 


\section{I62 SHOULD PRISONERS WORK?}

I feel that we have got to realize that probably one person in every ten makes his living, and I think I am very high when I say one in every ten; it is probably one in every fifty who makes his living working at one of the skilled trades. And it isn't necessary that all of our prisoners be trained to make their living in competition with this small group. Most of them must make their living by tending the various machines now used in factories, which is easily learned if they are taught to really work when they have found their new jobs. ${ }^{1}$

Wardens and superintendents, like other public officials and most human beings, are somewhat prone to justify the work which they carry on regardless of whether it is good or bad. Sometimes this praise by prison officers of "the dignity of honest labor" sounds a little forced and must be evaluated in the light of existing conditions within the particular institution. Mrs. O'Hare, for one, has expressed her doubts about the efficacy of contract "tasks" as a means of forming "the work habit." 2 Yet the universal agreement among prison administrators on the need of habituating prisoners to work deserves careful consideration. Steady work of any kind is certainly to be preferred to idleness.

We occasionally meet a point of view which starts with the premise that the difficulty with unskilled prisoners is their inability to meet new situations successfully. The remedy for this, so it is said, is to give each man as many types of

${ }^{1}$ American Prison Association, Proceedings (1926), p. 264.

2 "The Taxpayer's Burden," World Tomorrow, VIII (1925), 137-8. 


\section{PROBLEMS OF MANAGEMENT ${ }^{6} 6_{3}$}

training as he can absorb. The findings of Sheldon and Eleanor Glueck, in their study of the Massachusetts Reformatory, do not entirely bear out this theory.

One might imagine that the more industrial experiences the prisoner was given while in the Reformatory, the better equipped he would be for industrial success on his release. An examination into this question, however, discloses no relationship (or even a slight negative, rather than a positive, correlation) between the number of different occupational opportunities given the men in the Reformatory and their post-parole success, partial success, or failure. Thus, of the $35^{2}$ men involved, 62 had but one occupational experience in the Reformatory, and of these men $45.2 \%$ were industrial failures in the post-parole period, $54.8 \%$ were successes (combining partial success with success). But of the 216 men who had two or three occupational experiences, similar proportions were failures and successes (respectively $45.8 \%$ and $54.2 \%$ ); while as to the remaining 73 , who had over three occupational experiences, the proportion of failures was appreciably higher than among those who had but one occupational opportunity in the Reformatory - namely, 61.6\% were failures, $38.4 \%$ successes. ${ }^{1}$

In this particular statistical study the unskilled are not separated from the skilled, so that we cannot say the theory is definitely wrong, but over 50 per cent of the group were classed as unskilled both before and after the Reformatory period. Also, the different occupational experiences at the Reformatory may

${ }^{1}$ Reprinted from 500 Criminal Careers, by Sheldon and Eleanor $\mathrm{T}$. Glueck, by and with permission of and special arrangement with Alfred A. Knopf, Inc., authorized publishers. P. 196.

s.r.w. -12 


\section{I64 SHOULD PRISONERS WORK?}

have covered very short periods of time, serving not to teach a man but to confuse him. Furthermore, as Mr. MacCormick has pointed out, the man who fails to find the right job on his release is often one who has failed to adjust properly in prison, and so has been shifted from one assignment to another. ${ }^{1}$

Another theory of training, applicable especially to machine work, is that a man should not be trained in specific operations but should be taught "skills," as that term is technically used in this connection - i.e., the minimum requirements which are needed for given types of work. ${ }^{2}$ This idea obviates to some extent a difficulty which stands in the way of trade training, and that is the often prohibitive expense of keeping special equipment up to date so that a man does not find his newly-acquired training obsolete the day he is released.

To quote Dr. and Mrs. Glueck again:

... the Reformatory should teach men certain skills rather than particular narrow trades, for which there may be but a fugitive demand in our fast-moving industrial era; so that if they are unable to obtain employment at the precise occupation taught them, they will at least be well enough equipped in a general way to obtain some other employment.

\footnotetext{
1 Letter dated July Io, 1931.

2 For definition, cf. Industries for Correctional Institutions for Women (New York, 1927), pp. 19, 54-5.

Reprinted from 500 Criminal Careers by Sheldon and Eleanor $T$. Glueck, by and with permission of and special arrangement with Alfred A. Knopf, Inc., authorized publishers. P. 32I.
} 


\section{PROBLEMS OF MANAGEMENT 165}

On this basis, the garment industries could be justified. Men assigned to a sewing job would not be expected to find an identical job on the outside, but would be considered able to learn simple machine work of other kinds. There is of course a distinct tendency, noticeable (in the prison field) in Minnesota, to reduce the factory hand to an automaton, one who jerks a lever or performs certain tasks which are simple in character and are repeated over and over again. Perhaps the inculcation of habits of work is even more important than the teaching of "skills" which can usually be acquired without much effort. Yet having or not having the necessary skills may mean the difference between keeping and losing a job.

The most practical (though less widely recognized) conception of vocational training includes not only the highly skilled trades but "any training which fits a man for occupation, skilled or unskilled." 1 This immediately broadens the scope of vocational work in prisons, so that one may turn to account almost every occupation from dishwashing to foundry work. Mr. MacCormick gives the illuminating example of a course for janitors, which would include instruction in operating small heating plants, repairing

${ }^{1}$ A. H. MacCormick, letter dated July Io, I93I. For a very full and authoritative discussion of vocational education in prisons, cf. ch. 9 of Mr. MacCormick's book, The Education of Adult Prisoners (New York, I93I). 


\section{I66 SHOULD PRISONERS WORK?}

plumbing, locks, and electrical wiring, and using paints and cleaning compounds. ${ }^{1}$ Viewed in this perspective, special skilled trade training is seen as only one phase of vocational education, which also includes maintenance jobs and productive industries. Furthermore, no technical industrial training is of any value unless constantly practiced under actual production conditions - that is, the student must learn to approximate as closely as possible the speed and quality of work in similar free shops. To be worth the name, training courses must operate in connection with productive work, not in opposition to it.

\section{Job Analysis}

The reader will note that in our discussion we have reversed the order followed by scientific management in factory work, which is first to analyze the jobs and then to decide on the qualifications needed by the men who are to fill them. The prisons, it should be emphasized, are given men for whom they must find work and whom they must treat as individuals. It follows, therefore, that they should first analyze the men, then find the job which each man can do or be taught to do. In any long-range planning, the jobs must be built around the men. This is the basic principle of individualization which lies at the root of all modern penology.

${ }^{1}$ Ibid., p. 313. 


\section{PROBLEMS OF MANAGEMENT 167}

But when confronted with a given situation that is, with an institution already erected and with certain industries already installed - a director of prison work can at least determine what his institution has to offer his men in the way of jobs. In New Jersey we learn that -

... all of the work of the prison[s] has been analyzed into ... groups of jobs or places of employment. Each of these jobs has been analyzed to determine the most effective way to perform the work and the personal qualifications required of the worker for each stage. As examples of the latter, we have cases where the requirements, for instance in the printing industry, would call for educational experience equivalent at least to two years in high school. There are other jobs in printing where the only requirement is that of the ordinary fifthgrade grammar school education. ${ }^{1}$

An analysis of 444 jobs in the Trenton prison in 1920 showed 46 , or II per cent, rated as "very superior," 8 per cent as superior, 22 per cent as average, I 4 per cent as inferior and 45 per cent as very inferior. The jobs ranged from those of compositor, teacher, and electrician to those of coal passer, potato sorter, and runner. The manufacturing industries were represented by a shoe shop and a tag shop. ${ }^{2}$ Farm and road work were not included in the analysis, which may account for the exceptionally high perrentage of the lowest rating.

'Burdette Lewis, "Prison Labor and State Use in New Jersey," The Quarterly, III (April I, I925), IO.

2 Ibid., pp. $15 \mathrm{ff}$. 


\section{SHOULD PRISONERS WORK?}

With information of this kind on hand, an approach to the scientific handling of prisoners is possible. We have already seen how all new prisoners are studied in the New Jersey institutions, and how a summary of the several reports are placed before the classification committee some time within the first month of imprisonment.

As a result of the Classification meeting, decision is reached on the part of the Committee as to the placement for industrial work, training, school and other assignments within the Institution. Any indicated medical treatment, transfer, etc., may also be discussed at this time. Every man is given an assignment. A register is kept in such a way that when there is a surplus of men over jobs, an eligible list is established indicating which men are available for assignment when a vacancy occurs within a shop. These eligible lists are also established for assignment to road work and farm work and other special outside details involving special considerations. ${ }^{1}$

Day by day scrutiny of incoming prisoners coupled with a complete knowledge of existing jobs available will give clear direction to the development of future work programs and to the planning of new institutions.

\section{Maintenance Requirements}

In seeking to estimate the amount of employment - or rather of unemployment - existing in the penal institutions of this country, we

1 Committee Appointed by Commissioner Burdette G. Lewis, "Report on State Use Industries and Employment of Prisoners;" mimeographed copy, p. I. 
pointed out in Chapter II that institutional reports were often misleading in view of the very large assignment of men to maintenance work. One is quite justified in assuming that when this is the case it is proof positive of an excessive amount of idleness. But what percentage of the men should be assigned to the maintenance details in a reasonably run prison? The New York Prison Survey Committee investigated this subject and we give its conclusions:

Judging from the experience of the American army and from large institutions where maintenance work is carried on, it is estimated that 125 men out of each thousand will be required to conduct maintenance work. . . .1

This estimate of $121 / 2$ per cent for maintenance is low compared with the actual percentage of the population so employed in most prisons. Dr. Thayer found that about Ioo men out of 600 , or $162 / 3$ per cent, were needed to do the "utility work" at Napanoch. ${ }^{2}$ Maintenance percentages in twenty eastern institutions for men $^{3}$ range from 4.7 to 54 , and average about 26 , twice what the Survey Committee considered sufficient. It is somewhat significant that the low figure of 4.7 per cent is for a contract prison (Maryland House of Correction, Jessups), and the high figure for a state-use institution (West-

\footnotetext{
1 Report (1920), p. 126.

2 Institution for Defective Delinquents, 5th Annual Report of the Board of Managers (1927), p. 7 .

Taken from 1929 Handbook.
} 


\section{I70 SHOULD PRISONERS WORK?}

ern Penitentiary). The 54 per cent includes some men working on construction, but such is not the case with the next two highest figures 47 and 46.6 per cent. Southern prisons average much lower - 16 per cent. The Survey Committee calculated the maintenance percentages for four New York prisons, ${ }^{1}$ which are here compared with the Handbook figures for the same institutions in 1927 or early in 1928 :

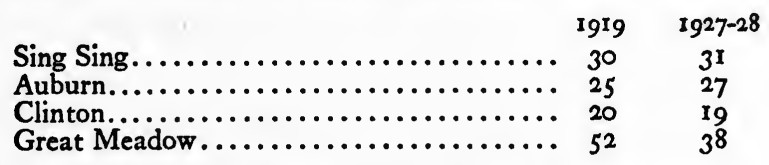

From this it seems that Great Meadow has managed to cut down its excessively large maintenance details, while the others have not varied much.

Allowing for physical and mental defectives and the incapacitated classes, there should be no more waste of labor power in prison than outside. Not only is it impossible to develop individuals without putting to full use the power that is within them, but we may also rest assured that waste of human effort in the prison routine will also cripple all plans for the rehabilitation of the offender which depend on his earning power for fulfillment. Of course if no other work can be found for prisoners, as many as possible should be used on maintenance. But we should

10 . cit., p. 126. 


\section{PROBLEMS OF MANAGEMENT I7I}

not accept large maintenance assignments as a settled policy of prison management, since rather they are an incident of poor management and restrictive legislation.

\section{Divided Management}

The success of any business enterprise depends very largely on the quality of the management and the control which it exercises over the various phases of production, sale, and distribution. A prison is of course something more than an industrial plant, and we have seen what a very great influence that "something more" exercises upon employment problems. The reader must remember that the prison's function as a place of restraint developed long before the industrial function and still holds first place. The man in charge of a prison was originally designated as a "keeper." The contract and piece-price systems allowed him to remain a keeper. But the development of the state-use and the state-account systems seem to imply that a warden should have had experience in manufacturing or large-scale farming or both. Our slowly developing technique of reformation and rehabilitation has also added many other duties to the position of warden, so that a wellrun prison of today has three major tasks - to keep its men confined, to employ them, and to rehabilitate them. There usually seems to be 


\section{I72 SHOULD PRISONERS WORK?}

considerable difficulty in finding a man capable of administering all three tasks successfully, and the tendency is to split the work among several men. Paul W. Garrett speaks of the-

... tendency in several of the larger states, in the reorganization of their penal systems, to decentralize to the point where the warden like the old King of France reigns but no longer rules.

When the various department heads in a prison are made responsible to the head of their department in the state office and report to him rather than to the warden, institutional unity is lost. ${ }^{1}$

This tendency to place different men in charge of the various functions of prison management is naturally stronger in large states having several state penal institutions than in states with but one. When Pennsylvania went over to the state-use system in 1915, it seemed advisable to place under one management the direction of the prison industries in the two penitentiaries and the reformatory. This arrangement is still in force. Central control implies central planning and it is only natural for the central office to want to build up its own force to carry out its ideas in the separate prisons.

Obviously, under a divided system of responsibility there are many opportunities for the development of friction, certain to affect prison

\footnotetext{
1 New York State Crime Commission, MS stenographic report of proceedings, November 22, 1929, p. 1463; as corrected in letter of August II, I93I.
} 


\section{PROBLEMS OF MANAGEMENT 173}

routine in undesirable ways. For example, who is to have the final decision in the matter of assignments - the warden, or the man appointed by the central office to supervise the industries? How is the working day to be arranged? Should school work come out of production hours or be confined to the evenings? If it is scheduled for evening, what about recreation? The educational director usually favors daytime classes, and the industrial superintendent objects to having production interrupted. Reformatories, where the educational features receive greater stress than in penitentiaries, sometimes resort to the device of the short work day and the double shift. Even bathing and shaving require more planning in prison than on the outside. Often the barbers go from shop to shop during working hours and each man in turn takes time off, while bath schedules call for each man's release at stated times. George C. Erskine of the Connecticut Reformatory inveighs against these interruptions of the working day in no uncertain terms:

You tell me there is no reason why a man should work eight hours in prison; that there are other things for reformation. There are, but you are training that man to go back into society; you should train him to [do] his day's work and get his recreation at some other time. His recreation should come, and his shaving and bathing should come, not when he is working any more than it should in our cases. He has a certain day's work to be 


\section{SHOULD PRISONERS WORK?}

done and the other things you and I don't do during our day's work should not be done by him.1

As might be expected, there is opposition to the tendency to split up the management of the individual prison. Wardens who see that the change means for them a return to their old status of keeper give way grudgingly; but there are impartial critics who feel likewise that the change will not be beneficial. Mr. Garrett, whom we have previously quoted, says:

My own feeling is, after watching that division of authority, that the states which have divided the control have so far certainly not achieved results comparable to those secured in other states which have retained a larger degree of unity in administration. ${ }^{2}$

Without going into detail (since this study is concerned solely with the various aspects of prison labor and not with prison management in general), we feel that a general statement on the subject will be useful at this point. It seems clear that a central board or department is a necessity for the successful planning and development of the work of the individual institutions. But we believe that in so far as it is possible the warden should be left in charge of all the manifold activities of prison life. We do not want as a warden a man who thinks of himself as a "keeper." There is and must be

${ }^{1}$ American Prison Association, Proceedings (1926), p. 264.

2 Testimony before New York State Crime Commission, November 22, I929, P. I463; as corrected in letter of August II, 1931 . 
in the conduct of a penal institution a unity or central theme which flows from an agreement on what a prison is for. Dr. Hastings Hart points out the situation that may exist when the prison fails to function as a whole:

... we have seen that in our prisons here the wardens and the superintendents of industry quarrel about which men should be put into shops; and the superintendent of industry felt that he must have the power to fire a man out of the shop at any minute if he did not prove effective, while the warden felt that the man should be in the shop for the sake of discipline, and for his training and fitting for citizenship. ${ }^{1}$

The following arrangement is suggested as a working plan for the organization of prison industries:

First of all, a careful study of the inmate population should be made, as suggested elsewhere in this chapter. Then comes a study of the possible market for goods, and a classification of institutional jobs. (We must always bear in mind that an efficiency engineer in dealing with a prison plant must reverse his ordinary technique of finding men to fit the jobs and begin with an analysis of the men and look for jobs to fit them.) Next is the decision of what to produce and the allocation of industries between the different institutions. A purchasing and selling organization must be created immediately, and a production division called into existence

Ibid., p. 1477. 


\section{I76 SHOULD PRISONERS WORK?}

likewise. All these tasks we believe can be better performed by the central board or department than by the individual warden. But the assignment of men, the decision as to working hours, and in short the full control of the prisoners should be in the warden's hands. With every important fact concerning the nature of the individual prisoner furnished him by specialists, he should be held responsible for the kind of men his institution turns out, and this, we must insist, is far more important than the kind of goods which are produced. The institution is his, and no board or department should by any arrangement or division of authority make him feel otherwise. We assume, of course, that he derives his authority from the same source as does the head of the industries, but his is the more important position in that he is charged with producing men, while the industrial superintendent is primarily interested in producing goods.

Finding Work for Misdemeanant Prisoners

Up to this point all that has been said about problems of industrial management has applied specifically to state and Federal prisons and reformatories. To repeat the discussion step by step and apply it to county and municipal jails, workhouses, houses of correction, and so on, would be largely beside the point, since the industrial problem takes on a different aspect 
in the institution for misdemeanants. The conglomerate population of the typical jail consists of men and women - sometimes children - held as witnesses, awaiting trial, or under sentence. The sentences may be as short as one day or as long as one year; in the jails of Massachusetts and Pennsylvania and in a few institutions such as the Detroit House of Correction prisoners with heavier sentences may be received. But in general the longest jail sentence is a year. Hence the population shifts very rapidly, a fact which at once complicates the matter of employment enormously.

Nevertheless, precisely as in a prison housing long-term offenders, we must begin by finding out exactly what types are to be dealt with and in what proportions they may be expected to arrive. The National Committee for Mental Hygiene has examined limited numbers of jail prisoners in eleven different states ${ }^{1}$ the South Carolina survey, made in I921, included 234 persons in seven county jails. ${ }^{2}$

The much more extensive survey in New York was made at the request of the State Commission of Prisons and is described as a study of "the

${ }^{1}$ Arizona, Georgia, Kentucky, Maryland, New York, Ohio, Rhode Island, South Carolina, Texas, West Virginia, Wisconsin. Cf. Winfred Overholser, Psychiatric Studies of Fail Prisoners in Massachusetts (reprinted from American Association for the Study of the Feebleminded, Proceedings, 1927), pp. 8, I6.

${ }^{2}$ G. C. Williams, "Crime and Its Treatment in South Carolina," Quarterly Bulletin (State Board of Public Welfare), III (I922), No. 2, p. 4 . 


\section{I78 SHOULD PRISONERS WORK?}

\section{mental and physical status" of 1,288 prisoners in thirty-four county jails and penitentiaries. ${ }^{1}$ We give the results of the mental diagnoses ${ }^{2}$ in sum- mary form:}

TABLE XVII

Classification of 1,288 Misdemeanants in New York*

Mental Status

Percentage

Normal......................... 22.9

Dullard............................... 7.2

Border-line mental defect............... 5.4

Mental defect....................... 7.6

Psychopathic personality............... 42.2

Psychoneurosis....................... I.5

Epilepsy.......................... 0.9

Mental disease or deterioration........... $7 \cdot 3$

Personality defect..................... 4.5

Unascertained....................... 0.5

Total......................... $\frac{0.5}{100.0}$

* A Plan for the Custody and Training of Prisoners Serving Sentence in the County Fails in New York State, p. 41.

1 A Plan for the Custody and Training of Prisoners Seroing Sentences in the County Fails in New York State, p. 38.

2 The Committee defined its terms thus:

Normal.-Those of at least average intelligence, free from nervous or mental disease and from pathological personality traits.

Dullard.-Those not actually feeble-minded but below average intelligence.

Border-line mental defect.-Those on "the boundary between definitely recognizable mental deficiency and the dullard."

Mental defect (feeble-minded).- "Those with a definite defect in intelligence which has existed from birth or shortly after ... morons, imbeciles or idiots. ..."

Psychopathic personality. -Those with "pathological personalities whose abnormality of make-up is expressed mainly in the character and intensity of their emotional and volitional reactions. The term ... has been shortened from the older one "constitutional psychopathic inferiority' with which it is synonymous." Feeble-minded not included.

Psychoneurosis. - Those with mental disorders having both mental and physical symptoms, including those of which the primary cause is "essentially physical" - hysteria, psychasthenia, neurasthenia, hypochondria, depression, etc.

Epilepsy.-Those subject to epileptic seizures or attacks of petit mal.

Mental disease or deterioration.-Those with "clearcut mental disorder," or deterioration following disease.

Personality defect.-Those in whom "pathological traits are . . . clearly in evidence ... but not sufficiently marked to warrant the diagnosis of "psychopathic personality." " Ibid., p. 39. 
The types distinguished by this classification resemble the groupings used by the American Prison Association and quoted above, rather than the administrative groupings worked out in New York and New Jersey. The high percentage of psychopathic offenders is striking, but must not be taken as conclusive and must certainly not be compared too closely with the results obtained by the I930 classification of state prisoners in New York without taking very carefully into account any differences in definition and in methods of examination.

Dr. Winfred Overholser has emphasized the necessity for supplementing psychological and psychiatric examinations with as full a case history as is possible in each individual case, ${ }^{1}$ and along such lines he developed the Massachusetts study of misdemeanants. We know of no other state which has undertaken so comprehensive and sustained an attempt to classify misdemeanant prisoners. The Massachusetts Legislature in 1924 appropriated $\$ 60,000$ "for a searching psychiatric study of prisoners in county institutions," ${ }^{2}$ and the Division for Examination of Prisoners was accordingly created in the Department of Mental Diseases. All persons sentenced to a county jail or house of correction for more than thirty days and all recidivists

IOp. cit., pp. 7, ro-r I.

${ }^{2}$ Commissioner of Correction, Annual Report (I925), p. 6. s.P.w. -13 
committed for any length of time-except persons serving sentences for non-payment of fine - are subject to examination. ${ }^{1}$ The Division is unable to handle all the cases but examines about one thousand annually; the total number examined from I925 to the spring of I93I is between seven and eight thousand. ${ }^{2}$ Since selection is necessary, prisoners with longer sentences are given preference in order to insure time for completing the examination. Social workers, psychiatrists, and psychologists make up the examining staff; the results are pooled and the findings, together with recommendations for treatment in various cases (upon discharge), are sent to the Department of Correction.

In the first $I, 500$ cases examined, 43 persons (3 per cent) showed signs of mental disease; 7 were considered fit subjects for schools for the feeble-minded and 79 were classed as defective delinquents - a total of 86 (6 per cent) with definite intelligence defect; I52 (IO per cent) were considered psychopathic. Institutional treatment is presumably advisable for most of these individuals. Chronic alcoholism warranting indefinite commitment was the diagnosis of $6 \mathrm{I} 7$ cases (4I per cent). The supervision of a social agency on discharge was recommended in 369 cases ( 25 per cent). Care

${ }^{1}$ Overholser, op. cit., p. 10 .

${ }^{2}$ Letter from Director of Division for Examination of Prisoners, May 18, 1931. 
by some community organization was recommended in I 5 cases. It was thought that family readjustment might be attempted in 33 cases, and that for 42 industrial supervision would be advisable. Eight cases were called "hopeless," 50 were "miscellaneous," and for 95 (6 per cent) there were no recommendations."

A detailed statistical study of the first five thousand cases is soon to be published and should afford many interesting data.

The Advisory Council on Crime Prevention (of the Department of Correction) employed a social worker to study the findings turned over by the Division for the Examination of Prisoners and to endeavor to have the recommendations put into effect.

By December I, I928, 5,700 psychiatric examinations had been received from the Division for the Examination of Prisoners and 1,570 individual cases had been acted upon since the beginning of this work. In the year preceding [i.e., 1928] there have been 576 conferences by letter or personal discussion with Miss Simmons, the psychiatric social worker, dealing with 480 cases. Of these conferences $34^{2}$ were with social agencies dealing with the community life of the person examined, 145 were with heads of the penal institutions, and 89 were with the police.

In all cases recommended for commitment as defective delinquent or drug addict, for treatment at a mental hospital or clinic, or for medical treatment, Miss Simmons has notified the head of the institution that he may deal directly with the inmate's need, transferring such a man

${ }^{1}$ Commissioner of Correction, Annual Report (1925), p. 6. 


\section{I82 SHOULD PRISONERS WORK?}

or establishing his connection with a local agency which will continue treatment. In some instances the sheriff calls in for consultation at the house of correction representatives of the local agencies who will co-operate.

In cases where the psychiatric examination recommends action at the time of a later arrest, this information has been sent to the local chief of police.

Men and women found to be in need of medical care are referred to the Department of Health, whose workers reinforce the sheriff's advice with visits to the inmates' homes and to local clinics, thus establishing regular treatment.1

These recommendations were in most cases for action to be taken upon expiration of the sentence to jail or house of correction, although transfer to the State Farm at Bridgewater might be recommended for alcoholics and drug addicts. So far, apparently, no particular attempt has been made to apply the results of the examinations to the industrial problem in the houses of correction. The difficulty, of course, is to finish the examination and devise an adequate program for the individual offender before his arbitrary sentence expires, and we are face to face once more with the problem of high turnover in institutions for misdemeanants. Classification studies are but an approach to this matter, and need to be reinforced by resentencing laws providing for indefinite commitment of defective and insane individuals - or by truly indefinite sentences in the first place.

1 Idem, Annual Report (1928), p. 18. 
In fact the obvious conclusion is that misdemeanants should be given indeterminate sentences. This was recognized clearly in the New York survey made by the National Committee for Mental Hygiene; the subsequent report recommended that all misdemeanants be sentenced indefinitely and turned over for thorough study to some central bureau such as the Massachusetts Division for the Examination of Prisoners. ${ }^{1}$ Recommendations for disposition of various types were, in brief, these:

Normal prisoners should be placed on industrial farms or in institutions with facilities for vocational training. Dull and borderline mental defectives should usually go to industrial farms. Definitely defective prisoners should be sent to special state institutions, such as Napanoch. Epileptics belong in hospitals for mental disease or colonies for epileptics. The insane belong in hospitals for mental disease. Psychoneurotics should be assigned to out-patient clinics of hospitals for mental disease and supervised by psychiatric social workers. Similar disposition is probably desirable for most psychopathic cases, although some must be institutionalized and some need vocational training. ${ }^{2}$

Certainly the ordinary jail is in itself the stiffest obstacle to employment that one could

\footnotetext{
${ }^{1}$ Plan for the Custody and Training of Prisoners Serving Sentences in the County Jails in New York State, p. 170.

${ }^{2}$ Ibid., pp. I 7 I-2.
} 


\section{SHOULD PRISONERS WORK?}

well devise. The industrial farm built on the plan of small units is far more flexible, and adaptable to the needs of more than one group. It is also a device for separating convicted from unconvicted, and wherever it has been tried out has proved its worth as a means of banishing idleness from the jail, that most perennial and aggravating of institutional problems. Examples are the Westchester County Penitentiary (New York), the District of Columbia Workhouse, the misdemeanant department of the Virginia State Farm, the Delaware County and Berks County jail farms in Pennsylvania, the Indiana State Farm. The first step, in every case, is to separate sentenced prisoners from those awaiting trial. The next is the use of the indeterminate sentence in connection with thorough classification studies and specialized institutions, usually of the industrial farm type. Such institutions, whether under state or local control, will encounter substantially the problems of management which have already been discussed in detail. 


\section{VI}

\section{COSTS, WAGES, AND PROFITS OF PRISON LABOR}

\section{Price Fixing}

1. By Legislative Fiat. Missachusetts, Missouri, Nebraska, Nevada, and Wisconsin specify in their laws relating to prison labor that the price at which prison-made goods are offered on the market shall be the prevailing market price or as near it as possible. In this legislative proviso there is the naive notion that the market price is unaffected by the presence of an additional supply of goods. The market price of an article at any given time is the resultant of certain forces or conditions affecting the supply and the demand. Other factors being equal, any addition to the supply will certainly affect the price, and the smaller the market in relation to the new amount offered the greater will be the effect; a larger supply of goods cannot be sold at the prevailing price without an increase in the demand. What, then, is a prison to do with the goods which it has made? It cannot store them indefinitely. If it places 


\section{86 SHOULD PRISONERS WORK?}

them on the market in any substantial amount, the inevitable tendency is for the price to decline and a new market price to prevail. Unfortunately, economic forces are stronger than the mandates of legislators. Goods entering the market, no matter by whom produced, exert an influence, great or small, on the prevailing market price.

2. On the Basis of Costs. That the selling price should be based on the cost of production is an idea which is slowly beginning to be reflected in legislation. The Minnesota laws provide that "binder twine and agricultural machinery and other manufactured products may be sold through agencies at a price to cover costs of production plus a fixed percentage."1 In Virginia "ground limestone, oyster shells, and marls are to be disposed of at a price to cover cost of production, wear and tear, upkeep, etc."2 In Washington "the output of factories, rock crushers, etc., not needed by the State is to be sold at not less than the cost of production...."3 Some persons seem to feel that if such provisions were widespread the problem of competition would cease to exist. It is said, for example, that prison twine plants "frankly fix their price, not upon cost, but upon the price of free labor twine,"4 the assumption being that this practice is what causes all the trouble.

${ }^{1}$ Monthly Labor Review, XXVIII (March 1929), p I3r.

2 Ibid., p. 136. 3 Ibid.

4 Conoict Labor in 1923, p. I35. 


\section{COSTS, WAGES, AND PROFITS 187}

\section{Labor Costs vs. Penological Costs}

A very fundamental difficulty in the way of arriving at production costs is the absence of any clear understanding as to what costs should be borne by society under any and all circumstances as a part of the expense of the existing penological program and what costs should normally be borne by a prison industry. Prison industrial projects may conceivably be saddled with costs which have nothing to do with industries but which are pure prison costs. To be considered a sound going concern, a business organization which produces goods for sale must receive, from the products which it markets, sufficient at least to pay for raw material, light, heat, power, office supplies, shipping costs, sales costs, machinery up-keep, repairs and improvements, depreciation not taken care of under repairs and up-keep, salaries and wages, compensation for injuries, and interest on plant and equipment. The pure prison costs which are sometimes lumped in along with these and charged against prison industries are the salaries of guards and other functionaries, the expense of maintaining great numbers of idle and incapacitated men, and an interest charge on very costly living quarters. The free industry of course pays taxes and these go to pay for police protection, the care of the poor, and for the other manifold activities of government. There 


\section{88 SHOULD PRISONERS WORK?}

is nothing, however, in the world of free industry with which to compare the host of guards who $\operatorname{dog}$ the footsteps of prisoners, nor is there any such burden of unproductive individuals or government overhead resting even indirectly on the free producer. In any financial comparison of a prison with an ordinary industrial plant, allowance must certainly be made for the fact that the prisoners are kept in an exceedingly expensive lodging house. It costs today from $\$ 2,500$ to $\$ 6,000$ per inmate bed to build one of the modern tool-proof structures which legislators and construction engineers insist upon as the only safe type of prison. Not even the most radical reformer has suggested so expensive a housing program for the working classes. Interest charges on the investment in the prison proper, as distinct from the shops, ought to be scaled down to the point where they would amount to no more than the interest on lodging homes which men of similar employment on the outside would occupy. It would be impossible to make a business pay if it had to provide sleeping quarters for its ordinary workmen in the most expensively built apartment house in the city.

On the other hand, we must not be fooled by the optimistic statements of certain prison authorities intent on showing a profit. From some reports it would appear that those in 


\section{COSTS, WAGES, AND PROFITS I89}

charge of prison labor felt they had made a profit if there was anything left over after paying for raw material, shipping and sales costs, and machinery up-keep. To such accountants, heat, light, power, plant, and labor are evidently free goods provided by nature.

"It is almost axiomatic," says H. B. Gill, "that the price policy which is adopted by the average prison industry is based upon accounting which the average high school graduate would know from a preliminary examination was absolutely unsound. I could quote illustration after illustration - and I made a very careful comparison of the actual cost analyses of the prices of certain products and their equivalents on the open market - and ... the units that made up those prices varied anywhere from 50 to 100 per cent. Materials obviously are always included in the price.

“. . . sometimes that is as far as many prison managers go in determining the cost of any product. Now, imagine putting on the market a product which is priced upon the cost of the materials. ... .

"Rent, overhead, selling costs, labor, are elements which the average prison industry just simply ignores." 1

Mr. Gill's criticisms of the prevailing accounting methods are unquestionably sound. The Department of Commerce found, on examining the accounts of prisons in various states, that:

I. Certain elements usually entering into costs - such as rent, many overhead items, selling costs, and sometimes factory labor - are absent.

2. Even when these elements are arbitrarily added in the analysis, frequently the amount charged is considered

1 Testimony before the New York State Crime Commission, pp. $138 \mathrm{I}-3$. 


\section{I90 SHOULD PRISONERS WORK?}

inadequate to bring them on to a basis comparable with ordinary factory operations. This is particularly true of factory labor costs.

3. Few of the best-managed prisons are making regular cost analyses of their products. 1

\section{The Revolving Fund}

In many of the states employing prisoners under the state-use or state-account system an effort has been made to separate industrial costs from prison costs by the device of a revolving fund. This is a sum of money appropriated by a state legislature to the institution or to some controlling board for the purchase of raw material and machines, the erection of shops, the salaries of free foremen, perhaps wages for prisoners, and for other incidental expenses. The money received from the sale of goods goes back into the fund, thus providing the wherewithal for the purchase of more raw material and for the continuous operation of the business. In the following table an effort has been made to group the institutions with respect to the use or non-use of a revolving fund.

TABLE XVIII

Relation of Industrial Earnings to Prison Accounts in

99 Institutions

(Source: 1929 Handbook unless otherwise noted)

Institutions maintaining revolving industrial funds:

United States Penitentiary, Atlanta (Federal Penal and Correctional Institutions, 1929)

United States Penitentiary, Leavenworth

1 Prison Industries, p. 16. 


\section{COSTS, WAGES, AND PROFITS I9I}

Connecticut Reformatory (fund maintained at $\$ 100, \infty 0$; any surplus over that reverts to state)

Florida State Farm (20th Biennial Report, 1927-28)

Illinois State Penitentiary (both old and new plants)

Southern Illinois Penitentiary

Illinois State Reformatory

Indiana State Prison \{ (fund used for state-use and state-account

Indiana Reformatory industries only; cf. institutional reports)

Iowa State Penitentiary (contract funds apparently kept separate from state-use and state-account industrial funds; cf. Report, 1927-28)

Kansas State Penitentiary (for twine plant at least, if not for all industries)

Massachusetts State Prison | (letter from Deputy Com-

Massachusetts Reformatory missioner of Correction,

Massachusetts Reformatory for Women December 27, 1930)

Michigan State Prison

State House of Correction and Branch Prison, Michigan

Minnesota State Prison

Missouri State Penitentiary (funds from "cut-make-and-trim" industries seem to be handled in with capital fund of stateaccount industries; cf. Department of Penal Institutions, Report, 1927-28)

Montana State Prison

State Prison, Auburn, New York

State Prison for Women, New York

New York State Reformatory for Women

Great Meadow Prison, New York

Clinton Prison, New York

Sing Sing Prison, New York

Ohio State Reformatory

Ohio Penitentiary (including two state brick plants)

Ohio Reformatory for Women

London Prison Farm, Ohio

Oregon State Penitentiary (Report, 1927-28)

Pennsylvania Industrial Reformatory

Eastern State Penitentiary, Pennsylvania

Western State Penitentiary, Pennsylvania

South Dakota Penitentiary

Washington State Reformatory (Department of Business Control, Report, 1926-28)

Wisconsin State Prison (revolving fund for twine industry only; cf. Report, 1927-28)

$$
\text { Total }-36
$$

Institutions maintaining separate industrial accounts which do not seem to be true revolving funds:

Colorado State Penitentiary (1927-28 Report)

Kansas State Industrial Reformatory (I927-28 Report)

Minnesota State Reformatory (1927-28 Report)

New Jersey State Prison

Wisconsin State Reformatory (1927-28 Report)

$$
\text { Total }-5
$$




\section{I92 SHOULD PRISONERS WORK?}

Institutions whose industrial earnings revert to state treasury:

Colorado State Reformatory (Report, 1928)

(Connecticut Reformatory - surplus over $\$ 100,000$ of revolving fund)

Connecticut State Prison

Idaho State Penitentiary (but funds so reverting have been devoted to prison improvement; cf. Report, 1927-28)

Iowa Women's Reformatory

Maryland House of Correction

Mississippi State Penitentiary

Nebraska State Penitentiary

Nebraska State Reformatory for Men

State Reformatory for Women, Nebraska (but funds so reverting are used to pay institution's accounts)

New Mexico State Penitentiary

Vermont State Prison and House of Correction (Report, 1928)

$$
\text { Total - II }
$$

Institutions whose earnings are part of prison accounts:

Federal Industrial Institution for Women (Federal Penal and CorUnited States Penitentiary, McNeil Island $\left\{\begin{array}{c}\text { rectional Institutions, } \\ \text { 1929) }\end{array}\right.$

Alabama Prison System

Arkansas Prison System

Connecticut State Farm for Women

New Castle County Workhouse, Delaware

Georgia State Prison Farm (Prison Commission, Report, 1927-28)

Indiana Woman's Prison (Report, 1929)

Kansas State Industrial Farm for Women

Kentucky State Penitentiary

Kentucky State Reformatory

Louisiana Prison System

Maryland Penitentiary

North Carolina Prison System

Oklahoma State Penitentiary

State Industrial Home for Women, Pennsylvania

Rhode Island State Prison and Providence County Jail

South Carolina Penitentiary (Handbook and institutional Reports)

Tennessee State Penitentiary
Brushy Mountain Penitentiary, Tennessee $\left\{\begin{array}{c}\text { (Handbook and Reports } \\ \text { of Department of } \\ \text { Institutions) }\end{array}\right.$

Texas Prison System (Handbook and Report, 1928)

Utah State Prison

Vermont State Prison and House of Correction for Women (Report, 1928)

State Farm, Virginia (Handbook and Reports of Penitentiary)

West Virginia Penitentiary

Wyoming State Penitentiary (Handbook and Reports of State Board of Charities and Reform) 
Institutions whose earnings appear to be part of prison accounts (data incomplete):

Arizona State Prison

Iowa Men's Reformatory

State Prison, Maine

Minnesota State Reformatory for Women

New Hampshire State Prison

New Jersey State Reformatory for Women

New York State Reformatory, Elmira

Institution for Defective Delinquents, Napanoch

North Dakota State Penitentiary

Oklahoma State Reformatory

State Penitentiary, Virginia (Handbook and Reports)

Washington State Penitentiary (Handbook and Department of Business Control, Report, 1926-28)

Total - I 2

Institutions with no earnings (no industries):

Nevada State Penitentiary

Rhode Island Reformatory for Women

Total -2

Institutions for which there is no data:

State Prison, Folsom, California

California State Prison, San Quentin

Illinois Women's Prison

Maine Reformatory for Women

State Reformatory for Men, Maine

Michigan Reformatory

New Jersey Reformatory (Rahway)

Total -7

Revolving funds may be increased or decreased by legislative action. For example "the [New York] legislature may make appropriations for capital investments in the industries, or sums may be appropriated from this fund for plant extension of other state institutions, but never for maintenance." 1 In view of the trouble in the Ohio State Penitentiary in April, I930, the following comment by the Department of Public Welfare on events connected with the revolving fund in that state is especially interesting:

${ }^{1}$ Ig29 Handbook, pp. 643-4. 


\section{I94 SHOULD PRISONERS WORK?}

The State Legislature in 1927 took away from the Manufacturing Rotary Fund $\$ 555, \infty 00.00$ and included it in the general appropriation bill under Maintenance for the purchase of clothing for the various state institutions. Of this sum $\$ 185,000.00$ was taken away July Ist and $\$ 370,000.00$ January 1, 1928. Prison industries were in this manner penalized and crippled for having a surplus working capital, a vital factor and essential in the further extension of prison industries to provide employment for the ever increasing prison population. Such action was taken regardless of the fact that a written statement was made outlining the contemplated extensions, including the London Prison Farm, covering a period of two years. These contemplated extensions would have given employment to 1,000 additional prisoners. In view of all the facts, such an act was wholly unjustifiable and only indicated that the Legislature as a whole, either was not familiar with our prison problems or was not concerned about them, or both. It will seriously retard and affect our industrial development and extension to keep within the limits of our reduced working capital and an increased number of prisoners must necessarily be continued in enforced idleness. 1

Considering the amount and the gravity of the idleness then existing in Ohio penal institutions, the Department appears to be quite correct in calling the action of the Legislature unjustified. For a legislature to take funds from accumulated working capital before the industries have been developed to the point of employing all the prisoners is good evidence of the slight interest which people have in the establishment of a sound penological program. The incident shows what is likely to happen to

1 Adoance Sheets: 6th Annual Report (1927), p. 20. 
revolving funds as soon as they attain any size. The Connecticut Reformatory is protected to some extent from such legislative depredations by the provision that any surplus over the $\$ 100,000$ which constitutes the revolving fund shall revert to the state, but the $\$ 100,000$ must be maintained. Sums from the revolving fund of the Kansas State Penitentiary have been appropriated by the legislature for capital expenses (new construction) at the prison. The revolving fund of the Minnesota plant at Stillwater has supplied large amounts for repairs and improvements, including new construction.

\section{Practice and Theory of Separating Costs}

The device of a revolving fund does not of itself insure accurate cost accounting; about all that it does do is to separate certain obvious industrial costs from the prison costs. The truth of the matter seems to be that few prison industries are really on a sound financial footing, and the problem becomes one of loading the industrial accounts with what costs they will stand, not with those which good principles of cost accounting would assign to them. This leads to confusion and to accounting practices that only serve to reveal the inefficiency of operation. Under the new Massachusetts wage system, for example, wages for maintenance workers come out of industrial costs, because B.P.w.-14 


\section{I96 SHOULD PRISONERS WORK?}

"these men are keeping the house clean for the fellow that is working. The same holds good for fellows who are doing the cooking for the men who are working."1 The Prison Survey Committee of New York proposed in I920 to deduct from wages "all sums expended in behalf of the prisoner by the state, including food, housing, care, administration, and guarding, and also his pro rata proportion of the wages paid to maintenance workers." 2 Pennsylvania legislation of 1925 directed that maintenance workers (who had till that date received no wage) should be paid not more than 20 cents a day from the Manufacturing Fund, i.e., the industrial revolving fund. ${ }^{3}$ The Secretary of Welfare's Biennial Report for 1927-28 contains the following statement of results:

There have been no appropriations turned into the Manufacturing Fund in over five years. During this time large sums have been expended in equipping, improving and establishing new industries. The Manufacturing Fund has, however, experienced some embarrassment during the past biennium due to its depletion by the application of the Maintenance Labor Payroll law enacted by the Legislature of 1925. It became necessary to suspend payments of Maintenance Labor payrolls from the Manufacturing Fund as of December I, 1927, because the total prisoners' payroll exceeded $80 \%$ of the net income. 4

1E. C. R. Bagley, Testimony before New York State Crime Commission, p. 1348 .

2 Op. cit., p. 123.

3 Secretary of Welfare, Biennial Report (1925-26), p. 69.

P. 87. 
However, the Annual Report of the Eastern State Penitentiary for the year ending May 3I, I929, says that maintenance men have been paid in accordance with law, ${ }^{1}$ so presumably funds were found with which to do so. In connection with such proposals and practices it is well to recall what has already been said on the subject of pure prison costs, namely: that the expense of guarding is a pure prison cost and the expense of administration partly so, while the housing cost should be scaled down to the modest charge which free workmen of a similar grade would incur for this item on the outside. Wages for maintenance workers ought not to be deducted from the earnings of industrial workers at all since they belong under the items "care" and "administration." The institutional accounts, which theoretically should receive maintenance deductions from the wages of men on the industrial payroll, should pay the wages of maintenance men.

But any deduction from each man's wages for food and lodging is a problem of institutional accounting. All charges for board, lodging, and other goods or services furnished to prisoners should be disregarded in the accounts of the prison industry and only wages should be reckoned in - not, however, those now paid but those which would be paid for similar work

\footnotetext{
${ }^{1}$ P. II.
} 


\section{I98 SHOULD PRISONERS WORK ?}

on the outside. If, for example, two prisoners were employed on a machine which was tended by one man on the outside, then each prisoner should be credited with but half the wages of the free workman, assuming of course the same number of working hours and speed of production per machine. What the prisoner ought to pay for his accommodations is, we repeat, a matter of institutional accounting. In our opinion, a proper system of cost accounting so far as the labor costs of the industry are concerned would begin and end with wages.

\section{Wages Now Paid to Prisoners}

But wages to prisoners are in actual practice something of an afterthought. Prison management or the state policy governing it has often resembled very closely the hard-boiled business man who pays his workers as little as possible and pockets the balance. Or sometimes, if the industry makes ends meet without allowing a wage, the management then experiments with a low wage scale, hoping that the extra stimulus will result in sufficient increase of production to offset the added expense.

'The notion that prisoners should be paid any wages at all has developed very slowly indeed and has met with some legal opposition. A prisoners' compensation law in Kentucky was held to be unconstitutional, but on technical 
grounds only. ${ }^{1}$ In Texas a similar law was declared unconstitutional on the ground that the convict was a slave. ${ }^{2}$ The court decided in a Rhode Island test case of $1913-16$ that although the convict was not a slave, the state yet had the right to the products of his labor. ${ }^{3}$ Nevertheless public opinion today tends to favor some kind of a wage for prisoners, even though the belief may not be put into very complete practice. Criminologists cherish the idea that the prisoner shall in certain cases compensate the victim of his crime, thus presupposing wages. It is the actual extent of present wage payments that we wish to examine next.

1. In Local Institutions. First of all, we have brought together some fragmentary data on the subject of prison wages in county and municipal institutions. The information was obtained by means of the employment questionnaire discussed in Chapter II, and has been summarized in Table XIX on the next page.

Only six states and the District of Columbia report the payment of any wages whatsoever, and in five of the six but a few prisoners receive payment. Four states and New York City definitely report that no wages are paid.

${ }^{1}$ L. D. Weyand, "A Study of Wage-Payment to Prisoners as a Penal Method," Fournal of Criminal Law and Criminology, XI (1920), 96-100.

2 E. H. Sutherland, Criminology (Philadelphia, 1924), p. 467.

"Karl W. Kirchwey, "The Prisoner - Ward or Slave?" in The Prison and the Prisoner, a Symposium, ed. by Julia K. Jaffray (Boston, 1917), pp. 75-9. 


\section{SHOULD PRISONERS WORK?}

The situation in Wisconsin is different. The "Huber Law" there provides that sheriffs may make arrangements with the county and with individuals for the employment of prisoners on farms, roads, and at other work. According to the State Board of Control, "the practical application of this law is limited to those communities where suitable and profitable employment may be obtained at any season of the year." 1 Hence jail prisoners in Wisconsin are not as a rule employed unless they can earn a reasonable wage, which is divided between themselves, their families, and the county.

\section{TABLE XIX}

Wages Paid to County and Municipal Prisoners, 1929-30

District of Columbia...... Wage system on trial (fiscal year 1930-31)

Georgia. at Workhouse and Reformatory

Massachusetts................ None

New Hampshire........... None

New Jersey............ I institution pays io to 50 cents a day; others give tobacco allowance

New York State.........Westchester County Penitentiary has credit

New York City............None system applying to length of sentence

Ohio...................About 200 men were paid from 50 cents to $\$ 3$ a day in 1929

Pennsylvania............ 3 counties pay for work done; some payments are in "good time," some in extra food and tobacco, some in money; money payments are on piece-work basis, or else range from 20 cents to $\$ 3$ a week

Rhode Island........... About 30 contract workers received a bonus for overtask in 1930

Tennessee............... None

$$
\text { None }
$$

Wisconsin..............In 1928, 468 prisoners earned $\$ 42,881.93$, of which $\$ 3 \mathrm{I}, 24 \mathrm{I} .40$ went to dependents, $\$ 10,666.42$ to counties, and \$974.II to prisoners

${ }_{1}^{1}$ Report covering year 1928, p. 12, quoted in letter from Chief Statistician, September I2, I930. 
In view of the vast amount of idleness which we know to exist in local institutions, and in view too of the paucity of data which we have been able to assemble, we shall have to be content with this brief mention of the wage problem in county and municipal institutions.

2. In State and Federal Institutions. For state and Federal institutions we have summarized the data presented in the 1929 Handbook, supplemented in five cases by material from other sources as noted at the foot of Table XX. The result is more like a confused picture puzzle than an accurate photograph, and too much reliance must not be placed on total figures and percentages. The figures for the ninety-eight institutions have been combined according to the same geographical divisions used in Tables III and X. The first column of figures shows the total number of prisoners employed, both productively and at institutional work, in the state institutions of each district and in the five Federal prisons. ${ }^{1}$ It has not been possible to separate the wage data for productive lines and maintenance lines completely, and the two types have therefore been combined in the table. The second column gives the total number reported as receiving compensation of any kind. These figures are next divided to show (Column 3)

${ }^{1}$ Comparison with Tables III and $\mathrm{X}$ will show slight differences in figures, due to additional data received on wages. 


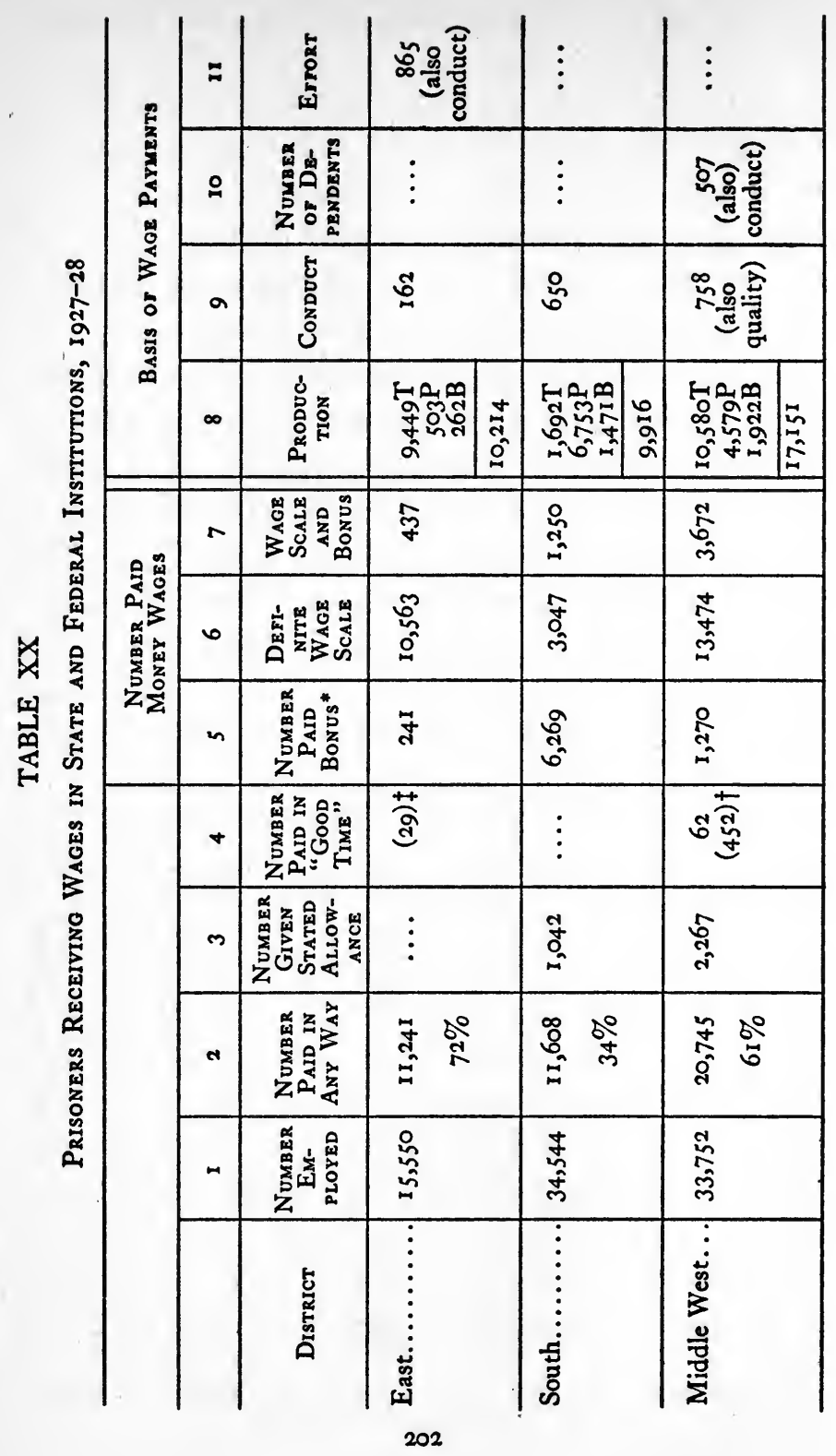




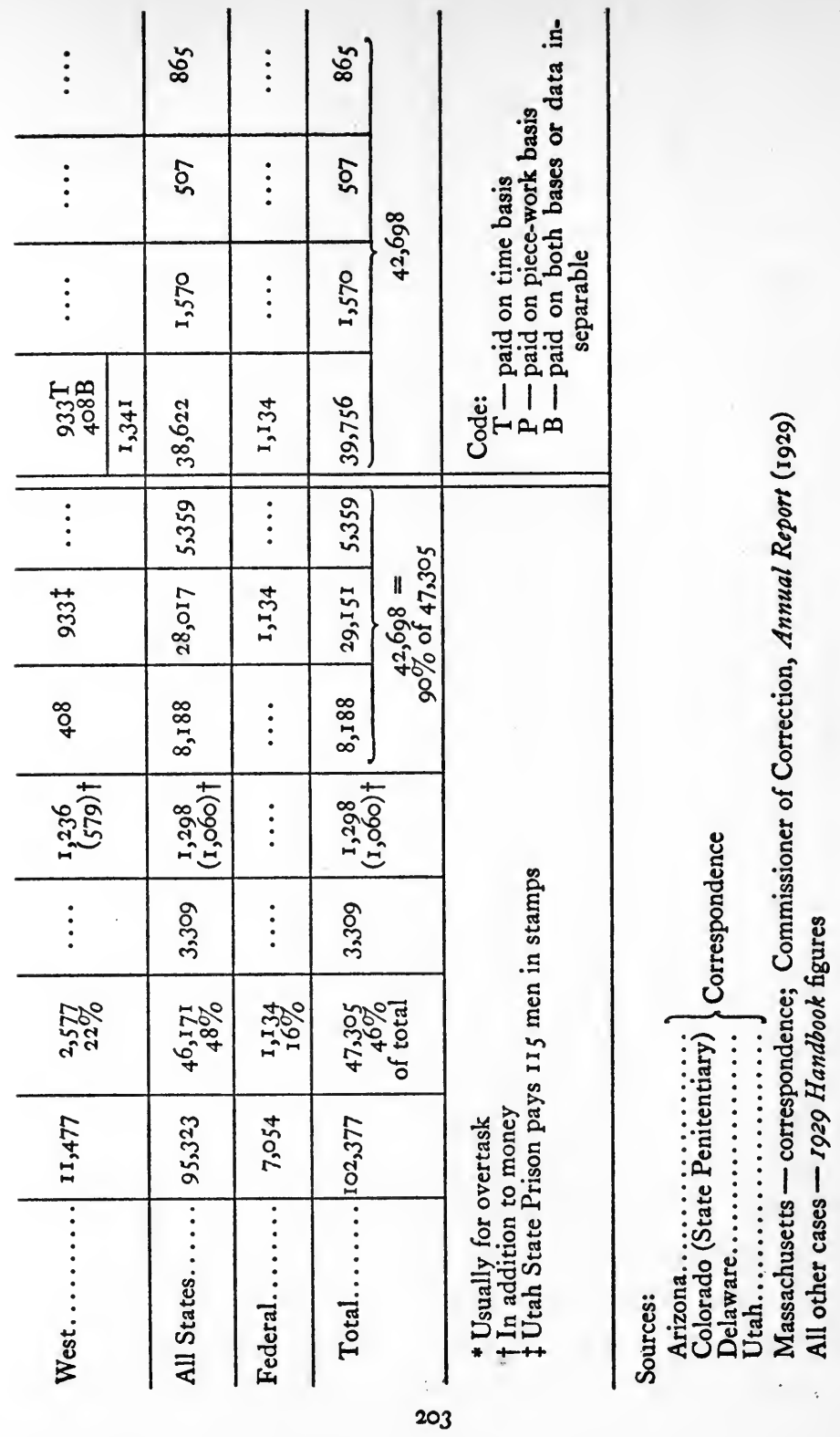




\section{SHOULD PRISONERS WORK?}

those receiving a stated allowance whether they work or not (this includes about 309 prisoners not working) those paid in "good time" commuted from sentence (Column 4), and those paid in money (Columns 5-7). The number receiving a wage in money is subdivided into three groups: those who are paid some form of bonus for their work, usually for doing "overtask," or more than is required of them in a day; those who are paid for their work according to some definite wage scale; those who work under a wage scale and also receive a bonus for extra work. Only these last three groups can be said to receive wages in the sense of money payments for services rendered, and it is these three only which are included in the accompanying study of the basis on which wage payments are made. Each basis of payment is represented by a column (8-II) and in Column 8 we have also indicated whenever possible whether the pay is determined on a time basis, output basis (piece-work), or a combination of the two.

Forty-six per cent of the workers $(47,305$ persons) were paid some sort of a wage. As we saw in studying the matter of employment itself, the various regions of the country differ in policy and in results. The East and the Middle West are both, on the whole, committed to the principle of wage payments to prisoners, and they succeed in paying about 70 and 60 
per cent, respectively, of their prison working forces. Without considering the amount of the wages paid or the terms governing them, and taking into account the difficulties of setting prisoners to work, this seems to us a very fair achievement. It should be remembered that idleness is a distinct problem in many of the states concerned. But the South, where prison idleness is reduced to a minimum - where 92 per cent of the prisoners are employed - pays only 34 per cent, or some 11,600 , of its prison workers. In the West only 22 per cent $(2,577$ persons) are paid. Many of the western states have not succeeded in establishing wage scales for the prisoners to whom they are able to give work. This is more apparent when we glance at Column 4 and note that nearly half of those receiving compensation in western prisons are paid in "good time," not money. No other part of the country uses "good time" extensively as a wage, though many states have "good time" laws applying to the whole prison population on a conduct basis.

That type of gratuity, sometimes mistakenly called a wage, which takes the form of a small money allowance to all inmates for the purchase of tobacco and similar luxuries, appears to be confined to Alabama and Kansas. However, the prisoners receiving such compensation outnumber those paid in "good time" for definite work. 


\section{SHOULD PRISONERS WORK?}

But the great majority $(42,698$ or 90 per cent) of those receiving compensation are paid in money for stated services rendered. (This includes II 5 men paid 25 cents a week in stamps, which are usually convertible into currency.) Over 8,000 receive a bonus only; some 5,000 receive a bonus in addition to regular wages; and the rest, over 29,000, are paid according to a definite wage scale for their assigned work.

From the original data condensed to form the preceding table, certain other pertinent facts are obtainable. Sixty-three of the ninety-eight institutions pay compensation of some kind to at least some of their prisoners. ${ }^{1}$ In only twenty-six do all the inmates receive compensation. Two institutions (in Alabama and Kansas) give prisoners an allowance whether they work or not - which can scarcely be called a wage; in Alabama the sum is 15 cents a week and is intended for tobacco. Most of the 8,000 prisoners receiving a bonus only are in southern institutions, eight of which pay in this manner alone, while but one eastern, two middle-western, and two western institutions grant bonus payments exclusively. The Middle West, however, leads in the number of prisoners paid both a regular wage and a bonus: five institutions in

\footnotetext{
I Fifty-one of the 104 state and Federal institutions reporting to the Bureau of Labor Statistics in 1923 paid some sort of compensation. Cf. Convict Labor in 1923, p. I5.
} 
that region use this method of stimulating production, as compared with two in the East, two in the South, and none in the West. (It might be added that there is some correlation between type of payment and type of shop: contract shops usually pay a bonus, if anything, which often means that the contractor, not the state, pays the wage, such as it is.)

In several institutions, particularly in the West, the custom prevails of paying men in "good time." This paradoxical phrase means that for so many satisfactory days' work one day is commuted from the minimum sentence. Such compensation obviously has no money value, but to a prisoner it may easily be worth more than money. The manager of the San Quentin furniture industry says that his men would prefer "good time" to money:

Some people suggest a form of compensation, but these men do not appear to want compensation. If they were allowed credits for extra fine work, which would apply on their terms, such as are allowed on highway construction work, we would have sufficient inducement. When asked which they prefer, compensation or credits, the answer invariably is "we want out." 1

This system of paying prisoners in "good time" for work done should be distinguished from the practice of reducing the length of the sentence for good behavior. There are two

1 E. S. Slack, "Industries Within the Walls of San Quentin," Tax Digest, VIII (May 1930), 159. 


\section{SHOULD PRISONERS WORK?}

institutions, the state penitentiaries of Arizona and Colorado, which pay in "good time" only. Workers in the California prison road camps, on the farms of the Vermont State Prison and in the coal mine of the Kansas State Penitentiary get a certain amount of "good time" in addition to their money wages. Four other examples of "good time" payments for work were given by C. S. Hyneman in 1927; Oregon, Wyoming, Montana, and New Mexico were the states cited. ${ }^{1}$

To summarize: Two of five Federal institutions pay money wages; fifty-eight institutions in thirty-six states pay money wages and three others representing two additional states pay in "good time" or grant an allowance - total, sixty-one institutions in thirty-eight states granting compensation of some sort. There are, then, ten states which pay no wages of any kind to prisoners, and those ten are Arkansas, Georgia, Illinois, Louisiana, Maine, Mississippi, Montana, New Mexico, Texas, and Washington. (Note that five are southern, three western, one middlewestern and one eastern.) This picture of the actual situation is to be compared with a recent statement that forty-one states make some legal provision for prisoners' wages. ${ }^{2}$

1 "The Problem of Providing Incentive for Prison Labor," Fournal of Criminal Law and Criminology, XVII (Feb. I927), 604.

2 General Federation of Women's Clubs, Department of Public Welfare, Program: Division of Correction, 1930, \& III. 
As indicated in the table, money wages are paid in three ways: (a) in the form of a bonus, (b) as a definite wage, or (c) as a combined wage scale and bonus. Examples of the straight bonus are the following: Rhode Island and Virginia pay from $\$ 2.00$ to $\$ 10.00$ a month for overtask; the Indiana Reformatory pays from $\$ 1.25$ to $\$ 2.75$ a month; Idaho pays $\$ 1.40$ to $\$ 4.43$ a month and Wyoming from $\$ 2.00$ to $\$ 3.00$. The bonus earned in the hosiery shop of the Wisconsin State Prison averages about 23 cents a day. The State Penitentiary at Nashville, Tennessee, distributes among its contract workers one third of the state's net earnings from the shops, plus stated amounts for overtask work. (In I927 and I928 the sum of $\$ 24,883.88$ was distributed, plus bonus payments totaling $\$ 15,274.46$. These amounts divided among an average of 1,600 prisoners come to only $\$ 15.55$ and $\$ 9.55$ per man over a period of two years, or a little more than a dollar a month all told.) ${ }^{1}$

\section{Basis of Wage Payments}

Definite wage scales may be based on output or on time - the hour, day, week, month. For the most part wages, no matter how paid, are based on production, but the large number in Column 8 gives an exaggerated impression.

1 Department of Institutions, Biennial Report (1926-28), pp. 358, 368-9. 


\section{SHOULD PRISONERS WORK?}

A common disciplinary device is to grade all prisoners according to conduct - as A, B, C and pay different wages to the different groups. Thus we find that in the Minnesota State Reformatory first-grade men get from Io to I 5 cents a day, and second-grade men from 6 to ro cents. ${ }^{1}$ Demotion for misconduct means, then, a lower rate of pay even though within the grade the wages are based on production. Similarly, at the London (Ohio) Prison Farm, men working under guard get I cent an hour, while honor men make 2 cents; and men "with dependent children under 16 years living in Ohio" receive 5 cents an hour, regardless of their class. ${ }^{2}$ There are of course various schemes of classification. In the South men are often separated into two groups - those who can perform heavy manual labor, such as road work, and those who cannot. In adult reformatories and in some state prisons the classification depends largely on conduct, coupled with progress along certain educational lines. We may well ask how any method of cost accounting worth the name could ever be devised in connection with such a wage system.

The piece-work basis which is so common for bonus payments is less used in paying regular wages. However, both Atlanta and Leaven-

1 rg29 Handbook, p. 500.

2 Ibid., p. 755. 
worth pay their shop workers by the piece, and the shoe shop of the Vermont State Prison pays about I4 cents per pair; ${ }^{1}$ the New Castle County Workhouse, the Eastern State Penitentiary, the Branch Prison at Marquette (Michigan), and the Nebraska State Penitentiary all pay by the piece in one or two of their shops. The hourly basis of pay is used in Ohio only, where the scale is from I to 5 cents an hour. Most prisons pay by the day or the month. Ten cents a day is very common; a dollar a day is unusual. The Stillwater wage scale, which is considered generous, is 25 cents to $\$ 1.00$ a day; ${ }^{2}$ in 1928 it was 25 cents to $\$ 1.25$, and averaged $371 / 2$ to 46 cents. Maryland has the same scale of 25 cents to $\$ 1.25$ in some of its shops. The only recorded wage higher than $\$ 1.25$ a day is $\$ 40.00$ a month paid to a prisoner dietitian in the Iowa State Penitentiary. The New Jersey Reformatory for Women appears to have the lowest wage scale in the country - 5 to 15 cents a week in April, 1928. Women's institutions, often more progressive, tend to lag behind prisons for men in the matter of wages.

As a rule a bonus in addition to regular pay is given only when the stated wage is quite small, say 3 to 18 cents a day, as in the Indiana

${ }^{1}$ Letter from Commissioner of Public Welfare, June 16, 1930.

2 J. J. Sullivan, "Prison Labor," Tax Digest, VIII (May 1930), 161.

S.P.W.-15 


\section{SHOULD PRISONERS WORK?}

State Prison. In Maryland the contract shops pay $\$ 1.25$ per task, of which $\$ 1.00$ goes to the state and 25 cents to the prisoner, but for overtask work the rate is $\$ 1.00$ and the prisoner gets it all. This seems to be unusually generous. The principle of paying a bonus for extra work is especially valuable for prison industrial purposes, where an incentive is vitally important, and one could wish it were more extensively applied.

\section{Theoretical Basis for Wages}

What should be the basis or bases of prisoners' wages is always a fruitful theme for discussion. It is generally assumed of course that the wages should bear some relation to the amount produced, that is, to the effectiveness of the prisoner as a worker. A powerful argument for a wage is that men will do more and better work for pay. There is striking testimony on this point. When the pay in some of the New York prison shops (at Clinton and Auburn) was increased from $\mathrm{I} / 2$ to 5 cents a day in 1925 , production increased noticeably. At Sing Sing the same thing happened twice, merely upon the announcement of new wage schedules which never materialized. ${ }^{1}$ Morale and efficiency in California prison highway camps improved with the inauguration of a wage system. ${ }^{2}$

${ }^{1}$ State Commission of Correction, 2nd Annual Report (1928), p. 69;

2 Ben H. Milliken, "Four Years" Experience with Convict Wage," California Highways, IV (Aug. 1927), 3, 6. 
Sometimes we note an effort to tie up the amount of the wage with the profitableness of the industry, which is quite different from making the wage depend on the efficiency of the worker as a producer of goods. The prisoners in a given plant may all be very capable workers, but manifestly the profits of the plant will be greatly influenced by management, the effectiveness of the sales organization, or by laws restricting the sale of the goods.

The Massachusetts law says that:

Whenever the rate of profit shall be in excess of such minimum rate at any such institution, the excess profit may be disposed of in the following manner: one half shall be placed to the credit of the prison industries fund of such institution and one half to the credit of such of the inmates of such institution as are entitled thereto in accordance with rules and regulations, which are hereby authorized to be established ... .1

Although wages should come out of the return from the sale of goods, it is questionable whether under existing conditions of prison industry the connection between profit and productivity is close enough to furnish an exact basis for determining wages. It is well to keep in mind also that the peculiar methods of accounting to which reference has already been made make profit depend largely on a division of expenditures as between prison and industry.

Penological and sociological motives constantly intrude in the discussion. Prison admin-

${ }^{1}$ Acts of 1928, ch. 387, p. 2. 


\section{SHOULD PRISONERS WORK?}

istrators generally favor a scheme of wages in which conduct figures as partial basis of payment:

Compensation and time off should be based on obedience to prison rules and discipline and excellence in workmanship. Without some inducement to the prisoners, it is difficult, if not impossible, to bring the quality of prison manufacture up to compare with commercial manufacturing on the outside, and this is essential, both from the standpoint of successful operation and the proper training of the prisoners. ${ }^{1}$

Both Mr. Burdette G. Lewis, ${ }^{2}$ formerly Commissioner of Institutions and Agencies in New Jersey, and Mr. E. C. R. Bagley, ${ }^{3}$ the Deputy Commissioner of Correction for Massachusetts, would take into consideration the effort a man puts forth. There seems to be a suggestion here that under present conditions of prison employment it is impossible to make production the sole test of what a prisoner should receive. Many people, especially prison administrators who have some knowledge of what happens to a man's family during his imprisonment, favor a wage system based on the number of a prisoner's dependents. ${ }^{4}$ At the hearings before the House Special Committee on Federal Penal and

1 [Washington] State Department of Business Control, 3rd Biennial Report (1924-26), p. I I.

"The Labor Phase of Correctional Treatment," National Conference of Social Work, Proceedings (I9I9), p. 108.

- Letter dated December 27, I930.

- Cf. Mississippi State Penitentiary, Biennial Report (1927-29), p. 23; Idaho State Penitentiary, Biennial Roport (1927-28), p. 7 . 
Reformatory Institutions in January, 1929, a member of the committee suggested that the Federal penitentiaries pay more money to the prisoners with dependents than to those having none. Captain A. H. Connor, at that time Superintendent of Federal Prisons, replied that to do so "would be just a dole," and went on to say:

In that way you would be putting the department purely into philanthropic business if you attempt to differentiate between prisoners according to need.1

In our opinion, there is at the present time little possibility of a prison industry paying the inmate enough to support his family. Many a free worker does not get enough to do so decently, certainly not enough to pay in addition large sums of money in reparation for any injury he may inflict on others. Consider what happens when an uninsured automobilist injures another person or damages a car: much less will a prisoner be able to meet his family's needs and pay damages to the party he has injured. We blithely theorize about impossible things. Miss Bloodgood's case study of prisoners' families in Kentucky brings out plainly the relative futility of the typical prison wage system in alleviating family suffering. Kentucky prisoners in 1926 could earn no more than Io cents a day except for overtask, overtime, or special work, and 25

1 Federal Penal and Reformatory Institutions, pp. 55, 56. 


\section{SHOULD PRISONERS WORK?}

per cent of whatever they earned went into a reserve fund for discharge ${ }^{1}$ the law did not require earnings to be assigned to a man's family:

The actual amount of money sent to the families was pitifully small as compared with their needs. At the rate of compensation in effect at the time of the study the amount the family might receive from men regularly employed during an entire year would be $\$ 23.4$, if all the father's earnings aside from the reserve were assigned to the family. Not even this amount was actually available, as it was necessary for the prisoners to retain some money for such personal expenditures as are essential for maintaining their morale. Twenty-six families had received less than \$10, although all but seven of the fathers had been in prison more than a year, and several had been confined from two to six years. Of the 82 families only 7 had received the equivalent of $\$ 20$ a year or more during the period of the father's imprisonment; most of the fathers in these families had received extra earnings which enabled them to make larger assignments. One man had sent his family \$1 36 from his earnings as a barber during his imprisonment of a little more than one year. ${ }^{2}$

The highest rate of pay discovered in the course of the present study was $\$ 1.25$ a day in the contract shops operated in the Maryland penitentiary in December, 1927.3 Allowing three hundred working days to the year and assuming that a man missed none of them, he would receive $\$ 375$ a year. Deducting $\$ 50$ for

\footnotetext{
1 Ruth S. Bloodgood, Welfare of Prisoners' Families in Kentucky (Children's Bureau Publication No. 182; Washington, 1928), p. 7.

2 Ibid., p. 34.

3 Except for one isolated case - the $\$ 40$ a month paid to the dietitian at the Iowa State Penitentiary.
} 
a reserve fund - which is moderate enough in view of the Massachusetts and Kentucky provisions for a 25 per cent reserve fund - he would have left $\$ 325$ with which to supply his own extras and support his family. This would be a decided help to many workingmen's families, but there are very few prisoners who receive so much. The 4 cents a day allowed inmates of the Kansas Penitentiary came to $\$ 12.50$ per capita in the year ending June 30,1928 , while men in the prison's coal mine averaged $\$ 7.72$ a year apiece for overtask. ${ }^{1} \quad$ The highest average pay at Stillwater was 46 cents a day in the farm machinery shops. A recent visitor to the prison reports that the average is now 50 cents a day. ${ }^{2}$ This would amount to exactly $\$ 150$ a year after deducting the reserve, $\$ 100$. One hundred dollars spread over a year is equivalent to about $\$ 1.92$ a week. Even if no deduction whatever were made and the family received every cent the man earned, the weekly income from this source would be a fraction over $\$ 2.88$. What family, however low in the scale of living, could support itself on that?

Until July I, I930, the state of New York enjoyed the doubtful distinction of paying the smallest wage doled out to men in any state or Federal penal institution, but on that date the

1 Twenty-sixth Biennial Report (1927-28), p. 43.

2 Mr. E. R. Cass; letter dated July I, I93I. 


\section{SHOULD PRISONERS WORK?}

hoary wage scale granting a cent and a half a day to many inmates was at last revised. Since the New York figures included in Table XX are for a date preceding the revision, it seems desirable to insert here a brief summary of the wage scale now prevailing in four important penal institutions managed by the richest state in the country. ${ }^{1}$ On September 30 , 1930, the wage status of the prisoners was this:

\section{TABLE XXI}

Prisoners Receiving Wages in New York, 1930

\begin{tabular}{|c|c|c|c|c|c|}
\hline Prison & $\begin{array}{l}\text { TOtal } \\
\text { NUMBER } \\
\text { OF Pris- } \\
\text { ONERS }\end{array}$ & $\begin{array}{c}\text { NUMBER } \\
\text { WORKINO } \\
\text { AND } \\
\text { PAID }\end{array}$ & $\begin{array}{c}\text { NUMBER } \\
\text { ILL BUT } \\
\text { PAID }\end{array}$ & $\begin{array}{c}\text { NUMbER } \\
\text { IDLE But } \\
\text { PaID }\end{array}$ & $\begin{array}{c}\text { NUMBER } \\
\text { IDLE AND } \\
\text { Not } \\
\text { PAID }\end{array}$ \\
\hline 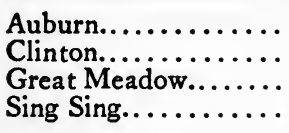 & $\begin{array}{l}1,722 \\
1,481 \\
1,046 \\
2,213\end{array}$ & $\begin{array}{r}1,525 \\
1,035 \\
967 \\
1,965\end{array}$ & $\begin{array}{l}29 \\
63 \\
62 \\
61\end{array}$ & $\begin{array}{r}68 \\
159 \\
17 \\
174\end{array}$ & $\begin{array}{r}100 \\
224 \\
17 \\
13\end{array}$ \\
\hline Totals........ & 6,462 & 5,492 & 215 & 401 & 354 \\
\hline
\end{tabular}

The only men not receiving wages were those idle because of disciplinary measures or because they refused to work. Those who were idle through no fault of their own, but from lack of work, received 2 cents a day none the less. Those excused from work because of illness were likewise paid 2 cents a day. Thus New York has recognized in its prisons the principle that a man should not be penalized because the management cannot keep him busy, and in effect

${ }^{1}$ Data from Chart CPI-6 prepared by Department of Correction, Division of Prison Industries. 
classes itself with the two states (Alabama and Kansas) which give prisoners a stated allowance irrespective of work. The old clumsy provision allowing the prisoner to be paid his share of a certain percentage of industrial earnings, after deductions were made for maintenance, etc., is also finally discarded and the prison worker is now paid for what he does. Wages for those men having jobs range from 5 to 30 cents a day; maintenance workers average less than men in the productive shops.

It is plain that the prison wage scales now in existence are with few exceptions unimportant sources of relief to the distressed families of prisoners. It also seems doubtful if one can greatly improve conduct, effort, or even production by making each man's portion depend on four or five different bases of payment, thus splitting up a wage already so small that it can hardly be parceled out without dividing the individual pennies.

By executive order President Wilson authorized the payment, to New Jersey prisoners engaged in war industrial work, of wages based upon the standard wage scales of the community surrounding the prisons. ${ }^{1}$ Samuel Gompers in I92I gave his tacit approval to the idea of paying prisoners according to "the prevailing

${ }^{1}$ L. D. Weyand, "Wage Systems in Prisons," Annals, CXXV (May 1926), 253. 


\section{SHOULD PRISONERS WORK?}

rate in the community," which may be considered as at least a semi-official expression of the labor attitude on this moot point. ${ }^{1} \mathrm{We}$ fully subscribe to this theory, but do not believe that it will be possible to put it into practice. To pay the standard wage, a prison industry must be as successful financially as are corresponding industries on the outside, but how can it be successful when suffering from the incompetency of political management and administration and burdened by restrictive laws which do not apply to free industry? Taxpayers will never submit to the excessive demands on the public purse which a scale of real wages would constitute.

It seems evident that unless the management of the industry is absolutely separated from the management of the prison, the wage system is rather certain to be used to subserve other than industrial ends. The writer is inclined to believe that the nearer we can come to making prison life resemble life in a well-regulated wholesome free community the more valuable will be the effect upon the individual prisoner. It seems, therefore, that the development within the prison of a wage system built upon a structure wholly different from that prevailing in the outside world will not be a good thing.

1 "Contract Prison Labor - the Shame of It," American Federationist, XXVIII (1921), 497. 


\section{Compensation for Industrial Injuries}

Connected with the problem of prison wages is the question of compensating prisoners for injuries received in the course of their work. In free industry the principle of workmen's compensation insurance for injuries or death incurred in the course of dangerous occupations is well established. The obvious injustice of forcing prisoners to do dangerous work without any possibility of redress in case of accident would seem to need no comment. Yet in general prisoners do not come under the various workmen's compensation laws, and but few steps have been taken to rectify the matter.

California has even gone so far as to refuse definitely to allow its prisoner road workers the status of employees eligible for accident compensation. The Supreme Court of California held in 1926 that the road camp bill of 1923 "made the convict an employee within the meaning of the compensation act" of I9I7 and that any prisoner injured while working in state highway road camps was as much entitled to compensation as a free workman. ${ }^{1}$ Whereupon the 1927 Legislature inserted the following provision in an act concerning road work by prisoners:

No convict so used on the State highway or roads shall be considered as an employee or be employed by the

\footnotetext{
${ }^{1}$ Monthly Labor Review, XXVIII (March 1929), 116.
} 


\section{SHOULD PRISONERS WORK?}

State highway commission, nor shall any such convict come within any of the provisions of the workmen's compensation, insurance, and safety act of 1917 or be entitled to any benefits thereunder whether on behalf of himself or that of any other person. 1

Professor A. H. Schwartz remarks that as a rule "the injured convict may prosecute his claim against the state only after permission is granted him by the state," 2 which indicates that we are here involved in the confusion surrounding law and practice concerning loss of civil rights upon conviction of a felony.

The New York Prison Survey Committee of I 920 considered the subject of industrial injuries in connection with its recommendations for prisoners' wages. It recognized clearly the state's responsibility in the matter:

In the section of this report on "Industries," it is pointed out that the machines in the prisons lack proper safety devices. There is no free factory in the state which could safely stay open for a week with its machines in such an appalling condition. In this situation a prisoner who is maimed through the failure of the State to provide proper safety devices appears to have no redress. A free man who is maimed in the pursuit of his occupation receives compensation for his injuries under the Compensation Law through insurance. The prisoner is not insured and no case in New York State shows that he has a right to damages from the Court of Claims.

When the court sentences a man to prison and the State assumes his custody and puts him to work, it should

1 Ibid., quoted from Acts of 1927 , ch. 653.

2 "Legal Aspects of Convict Labor," Fournal of Criminal Law and Criminology, XVI (1925), 274. 
assume at least this much responsibility for his safety. On the adoption of the wage system which has been outlined, it is recommended that the provisions of the Workmen's Compensation Act for injuries be extended to the prisoner. It is recommended that the State Industrial Compensation Commission draw up a progressive scale based on the wages paid to prisoners (on the adoption of the wage plan) and that from the profits of the industries be paid to the State Insurance Fund a sum to insure the inmate on the same basis as woula be required of an employer under free labor.

Pending the adoption of the wage scale, it is recommended that provisions be made for the filing and hearing of claims with the Court of Claims, prior to the time that the prisoner is to be released, for any industrial injury that the prisoner may have sustained during his incarceration. ${ }^{1}$

J. B. Andrews cites the case of an Auburn prisoner who in 1924 lost a hand in an embossing machine at the tag shop and goes on to remark:

There are perfectly well known devices to prevent such accidents on stamping machines. The state of New York was at fault in failing to provide in its own institutions the simple safeguard that it requires as common practice in private industry. ${ }^{2}$

Such a flagrant case of culpable inconsistency on the part of the state should have aroused more widespread condemnation and prompt remedial measures, but a bill to provide workmen's compensation for convicts failed to pass the New York Legislature in $1925 .^{3}$ Cases of

\footnotetext{
1 Op. cit., pp. I3I-2.

"Workmen's Compensation for Convicts," American Labor Logislation Reoiew, XV (June 1925), 133.

Ibid.
} 


\section{SHOULD PRISONERS WORK?}

injury sustained by convicts while working for the state may now be heard by the Court of Claims, however. ${ }^{1}$

Alabama at one time authorized the accumulation (from prison earnings) of a fund to compensate prisoners who might be injured while working in the mines, but we do not know whether or not any payments were ever made, and since the closing of the mine prisons nothing has been heard about industrial compensation for prisoners in that state. ${ }^{2}$

The Massachusetts Commissioner of Correction recommended a prisoners' industrial compensation law to the state legislature in 1928 , but apparently nothing came of it. ${ }^{3}$

There are three states which allow their prisoners some compensation for injuries received in connection with prison occupations. They are New Hampshire, ${ }^{4}$ Maryland, and Wisconsin.

The Maryland law applies to prisoners "engaged in any extra hazardous employment ... for which wages or a stipulated sum are paid either to the institution or to the prisoner" 5 or for which some sum is paid by the institution itself:

... the state industrial accident commission in awarding compensation in cases of injuries to prisoners in the

1 Laws of 1929 , ch. 467 .

2 State Board of Administration, 2uadrennial Report (I922-26), p. 42.

3 Commissioner of Correction, Annual Report (1928), p. Io.

Ig29 Handbook, p. 58.

'Acts of 1927 , ch. 660, quoted in Monthly Labor Review, XXVIII (March I929), II7. 
course of their employment, shall direct that all of the compensation for which the employer of said prisoner is liable hereunder, shall be paid to the institution in which the said prisoner is confined at the time of his injury, and out of the compensation paid to any such institution under the provisions of this article, the institution shall retain a sum equal to the average weekly amount received by said institution (if the compensation shall amount to so much) for the labor of said prisoner over and above any bonus received by or for the use of said prisoner, and the surplus of any such compensation, if any, shall be credited to and belong to the injured prisoner ... When such prisoner shall resume work any compensation to which he may still be entitled by reason of partial disability, temporary or permanent, shall be payable to the institution and first applied toward reimbursement to the institution for any loss which it may sustain in the earnings of said prisoner by reason of his injuries, and the balance, if any, shall belong to .... such prisoner. Upon the discharge of the prisoner... the remainder of the compensation for which the employer may be liable hereunder shall be paid directly to the prisoner. . . .

[When the institution is the employer] the average weekly wages of any such prisoner injured in the course of his or her employment shall be the average weekly wages paid by said institution to such prisoner, and in addition thereto a fair and reasonable sum to be determined by the State industrial accident commission for the board and maintenance of such prisoner not to exceed the amount customarily received by the institution for its own use for prisoners engaged in extra hazardous employments for private employers. The State industrial accident commission in making awards to such prisoners so injured in the course of their employment, shall direct the institution employing such prisoner to deduct from its award the sum found by it to be reasonable for the board and maintenance of such prisoner, in determining 


\section{SHOULD PRISONERS WORK?}

the average weekly wages, and the balance, if any, shall belong to and be credited to the account of such prisoner. Upon the discharge of such prisoner .... the said institution shall pay the remainder of the compensation to which any said prisoner shall be entitled, to the prisoner ....

In case of death, the prisoner's dependents are entitled to any compensation which may be awarded or remaining. Recalling the Maryland contract scale of $\$ 1.00$ per task to the institution and 25 cents to the prisoner, it scarcely looks as though the latter were likely to receive much compensation after all the authorized deductions have been made. The law is interesting not only as affording some protection to the prisoner in case of injury but as an effort to protect the institution against loss in its contract revenue because of disabled workers.

The Wisconsin law was also passed in 1927 and is much simpler, providing that any prisoner permanently incapacitated or suffering material reduction of his earning power through industrial injuries may upon discharge be entitled to compensation (after examination of his case by the industrial commission) "on the same basis as though such injury had been covered by the workmen's compensation act, except that the total of the sum paid to any such inmate shall not exceed $\$ 1,000$ and such sum may be paid to

\footnotetext{
1 Acts of 1927, ch. 660.
} 
such inmate in partial payments" from the prison revolving fund. ${ }^{1}$

As with regular wages, so with compensation for injuries: almost everyone can agree that the prisoner should receive accident compensation, but finding the money to pay him with is another matter. Shall the prison industries bear the charge? Theoretically, yes, but we have seen only too well that they usually will not be able to afford it. Then shall the state treasury bear the burden? There will be less agreement about this solution, though if it were put into effect we may be sure that prison shops would be equipped with all necessary safety devices. ${ }^{2}$ A further puzzle is the determination of the exact amount. Is this to depend on the wages paid? But suppose no wages are paid? Or if they are, how could compensation for injuries possibly be related to wages insignificant in amount and based (as they often are) on other things than industrial efficiency alone? We are again brought face to face with the confusion that arises from the peculiar nature of the prison labor world.

\section{Prison Profits}

Let us now try to discover what the prison (or the state) makes out of the employment of

${ }^{1}$ Act of 1927 , ch. 241, quoted in Monthly Labor Review, XXVIII (March 1929), i 8.

In this connection it is interesting to note that any employer leasing prisoners in Italy must at his own expense take out complete accident insurance for such workmen. Cf. Prison Industries, p. 84.

M.P.พ. -16 


\section{SHOULD PRISONERS WORK?}

its prisoners. Have our penal institutions been turned into profitable industrial organizations or do they constitute an ever-increasing burden upon the taxpayer?

1. Gross and Net Per Capita Costs. The average per capita cost of maintenance alone for eighty-eight state and Federal institutions was, according to a report of the Bureau of the Census, ${ }^{1} \$ 334.75$ for the year 1927. Thus if the prisoners had earned for their institutions an average of \$I.I5 per day, assuming three hundred working days a year, they could have more than paid the salaries and wages of prison guards and officials and the expenditures for provisions, fuel, light, water, etc.- in short for everything that is usually included under the heading of maintenance charges. If they had earned an average of $\$ 1.36$ per day, they could have paid for all expenditures, including improvements, additions, and other expenses incurred in the year 1927, for the total per capita cost including these items was but $\$ 407.61$. In other words, these eighty-eight state and Federal institutions would have been entirely selfsupporting, barring a return on invested capital, if each prisoner had paid the prison, on the average, \$I.I 5 a day for his board and lodging.

We have been able to bring together the gross and net per capita costs of operation for certain

1 Prisoners: 1927, p. 124. 
institutions, and present the figures in tabular form, with the source and comments in each case (Table XXII).

Most of the scattering examples are for a fiscal year ending some time in 1928. The difference between the gross and the net per capita costs is presumably the average per capita return from the labor of the inmates; in seven cases this is definitely so (see note at end of table). Net earnings include amounts paid into revolving funds.

In spite of the insignificant wages paid (if any), only one institution shows a surplus, and that is the West Virginia Penitentiary, which employs its prisoners under the contract system. The Kentucky State Reformatory, where the main industries are also on a contract basis, comes very near to achieving a surplus, with a net per capita cost of only 69 cents. The Minnesota State Prison at Stillwater, which for I928 shows a net per capita cost of \$I88.I9, had a per capita surplus of $\$ 1.59$ in 1927 and $\$ 20.83$ in I929. ${ }^{1}$ This prison has long been the shining example of what state-account industries can do financially. By means of its binder twine and farm machinery plants it has supported itself since $1917,{ }^{2}$ which means that the only appropriations necessary are for extraordinary expenses such as new construction or the purchase of

1 Twenty-sixth Biennial Report (1929-30), p. 26.

2 Twenty-fifth Biennial Report (1927-28), p. 6. 


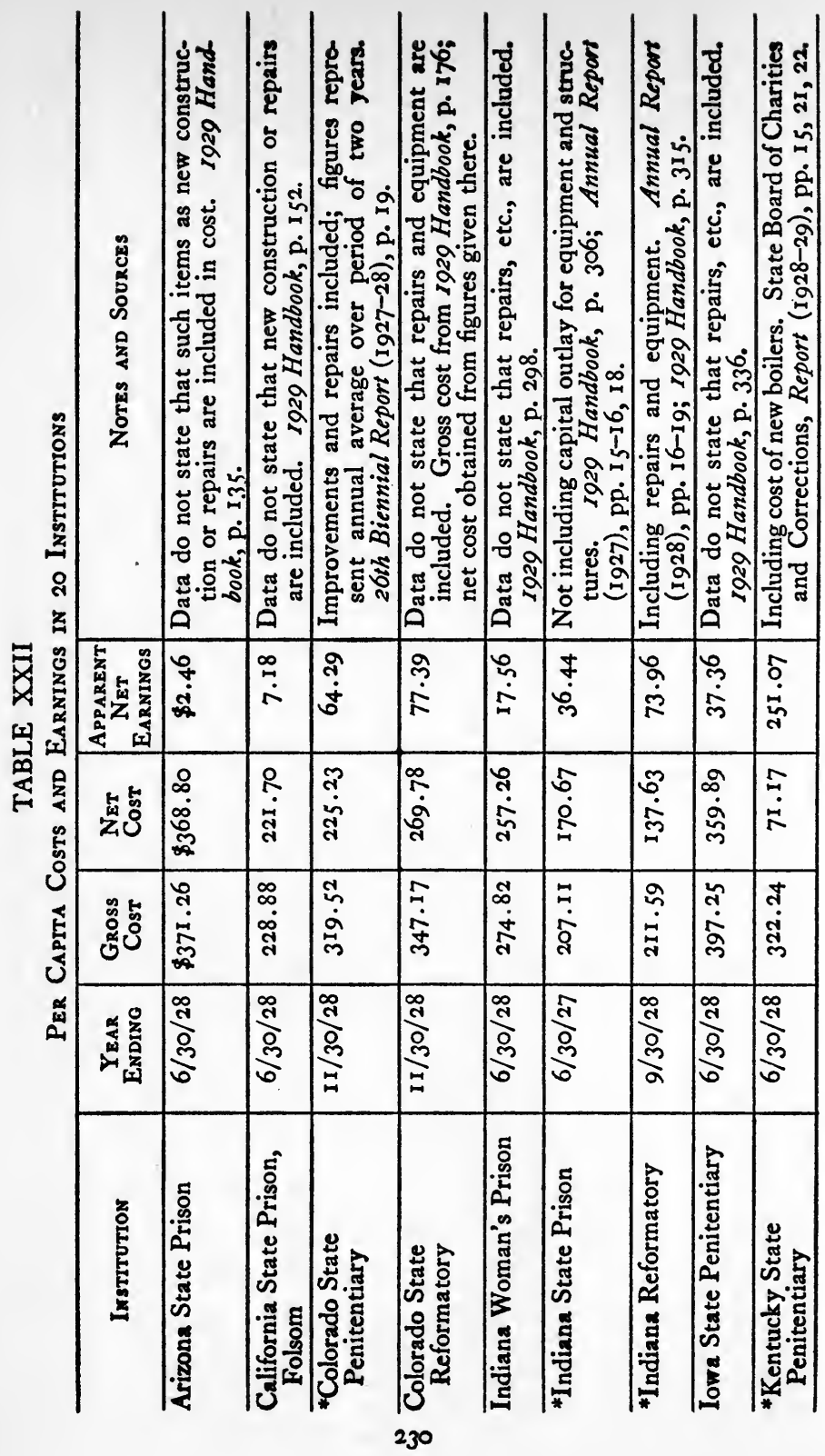




\begin{tabular}{|c|c|c|c|c|c|c|c|c|c|c|}
\hline 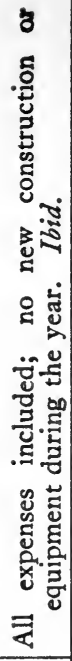 & & 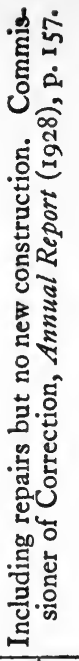 & 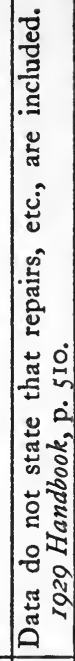 & 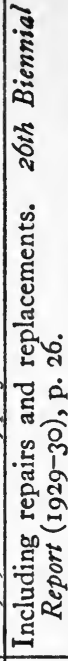 & 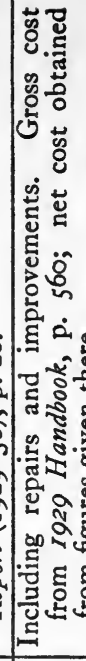 & 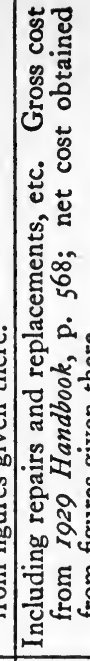 & 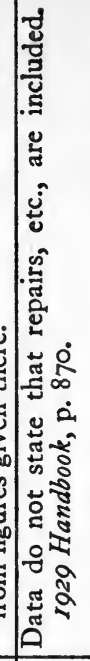 & 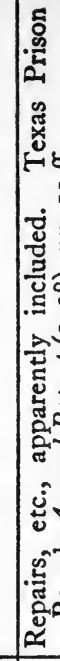 & 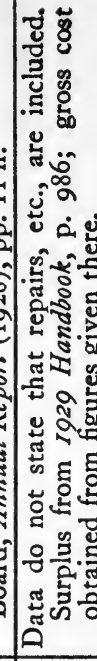 & 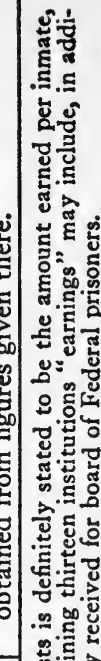 \\
\hline ণ্ণ & \begin{tabular}{l|l}
$\hat{a}$ & के \\
aे & वें
\end{tabular} & 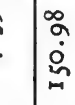 & 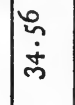 & $\mid$ & 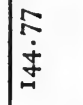 & 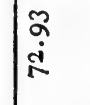 & $\mid \begin{array}{c}\infty \\
0 \\
0 \\
0 \\
\end{array}$ & & 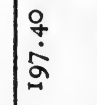 & \\
\hline 8 & 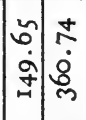 & 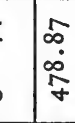 & 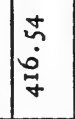 & $\mid$\begin{tabular}{c}
$a$ \\
\hdashline \\
$\infty$ \\
0 \\
$\sim$
\end{tabular} & 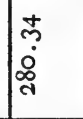 & 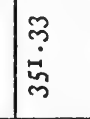 & 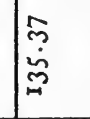 & & 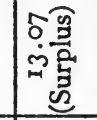 & \\
\hline & 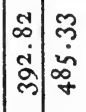 & $\mid \begin{array}{c}2 \\
\infty \\
\text { âे }\end{array}$ & 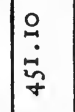 & $\mid \begin{array}{l}\text { an } \\
\dot{\hat{q}} \\
\bar{\gamma}\end{array}$ & 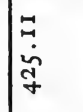 & 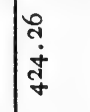 & & & & \\
\hline 耪 & 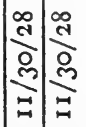 & : & $\underset{\substack{\infty\\
}}{\stackrel{\infty}{r}}$ & & 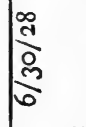 & i্ & 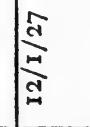 & & 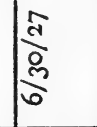 & \\
\hline 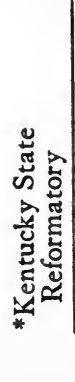 & 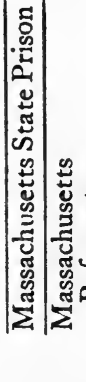 & 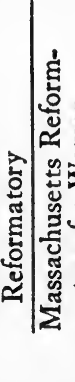 & 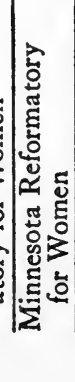 & 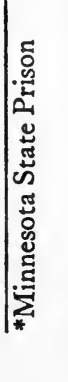 & 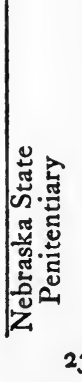 & 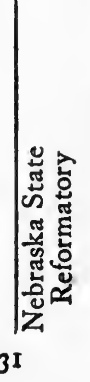 & 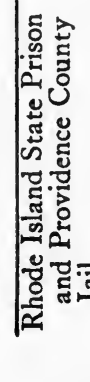 & 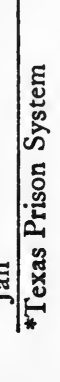 & 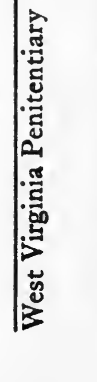 & \\
\hline
\end{tabular}




\section{SHOULD PRISONERS WORK?}

additional land, while the cost of at least one new cellhouse and many minor improvements has been covered by surplus transferred from the industrial revolving fund. ${ }^{1}$ Even the 1928 deficit did not necessitate an appropriation, but was met from the accumulated surplus of the revolving fund. ${ }^{2}$

An interesting point that should be noted in scanning Table XXII is the variation in earnings from state to state and from institution to institution within the same state. Thus Nebraska's penitentiary and reformatory are less than a dollar apart in gross per capita cost, but the net per capita earnings of the one are $\$ 7$ I.84 greater than those of the other. The Rhode Island State Prison and Providence County Jail, a combined institution with a difficult administrative problem on its hands, reduces its per capita cost more than half by means of a shirt contract. The three southern institutions listed (besides West Virginia) show a net per capita cost under a hundred dollars. Five institutions in other districts (East, West, Middle West) have a net per capita between one and two hundred dollars.

Some interesting figures on per capita costs and earnings in different types of institutions may be obtained from data given in the 1929

${ }^{1}$ Ibid., p. 13. Also United States Daily, V (Supplement, July I4, 1930), 21.

2 Twenty-sixth Biennial Report, p. I3. 
COSTS, WAGES, AND PROFITS 233

report of the Massachusetts Commissioner of Correction:

\section{TABLE XXIII}

Per Capita Costs and Earnings in Massachusetts*

\begin{tabular}{|c|c|c|c|c|c|c|}
\hline 4 & 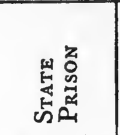 & 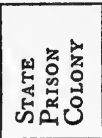 & 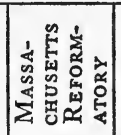 & 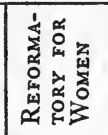 & 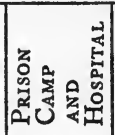 & 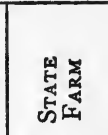 \\
\hline $\begin{array}{l}\text { Gross per capita.. } \\
\text { Net per capita.... }\end{array}$ & $\begin{array}{r}\$ 431.76 \\
136.53\end{array}$ & $\begin{array}{r}\$ 713.72 \\
704.78 \\
\end{array}$ & \begin{tabular}{|r|}
$\$ 468.11$ \\
353.60
\end{tabular} & $\begin{array}{r}\$ 571.34 \\
395.65 \\
\end{array}$ & $\begin{array}{r}\$ 656.05 \\
615.60 \\
\end{array}$ & $\begin{array}{r}\$ 258.84 \\
251.35 \\
\end{array}$ \\
\hline $\begin{array}{l}\text { Per capita saving } \\
\text { to state........ } \\
\text { Per capita indus- } \\
\text { trial profit..... }\end{array}$ & $\begin{array}{l}\$ 295.23 \\
\$ 282.69\end{array}$ & $\$ 8.94$ & $+\left|\begin{array}{l}\$ I_{4} .5 \mathrm{I} \\
\$ 92.86\end{array}\right|$ & $\begin{array}{l}\$ 175.69 \\
\$ 136.68\end{array}$ & $\begin{array}{l}\$ 40.45 \\
\$ 36.88\end{array}$ & $\begin{array}{r}\$ 7.49 \\
\ldots\end{array}$ \\
\hline
\end{tabular}

* Commissioner of Correction, Annual Report (1929), p. 178.

Here "gross per capita" cost includes all expenditures except new construction, and "net per capita" represents the actual cost to the state for each prisoner in its charge during the year. "Per capita saving to state" represents both industrial earnings and institutional income such as sales of light and power, of farm products, of arts and crafts products, of laundry work. The "per capita industrial profit" is that part of the per capita saving which results from the specific activities of the industrial shops, and is found by dividing the industrial profits of each institution by the average number of inmates.

In not one institution do the earnings from the industries equal the cost of supporting the prisoners. The State Prison has, naturally 


\section{SHOULD PRISONERS WORK?}

enough, the largest industrial income, resulting in the greatest per capita saving. But it is surprising that the per capita industrial profit of the Reformatory for Women should be more than forty dollars greater than that of the men's reformatory. The new Prison Colony still under construction by inmate labor has no productive industries in operation, and neither has the State Farm, with its varied population of misdemeanants, paupers, defectives, drug addicts, inebriates, and insane prisoners. The Prison Camp and Hospital shows more of a profit than one might expect from an institution housing hospital and tubercular cases transferred from the other units in the correctional system.

In 1929 one competent observer, Superintendent Howard B. Gill of the Norfolk Prison Colony, estimated that the Massachusetts shops were working "at about $33 \frac{1}{3}$ per cent efficiency," and yet he considered that that state was "in some ways" nearer than many other states to solving the problem of prison industry. ${ }^{1}$ The per capita earnings of the State Prison for 1928 compare very favorably with those of the other institutions in Table XXII. One factor in the good industrial showing of Massachusetts institutions is that offenders with sentences of less than two and one-half years remain in local

\footnotetext{
${ }^{1}$ Testimony before New York State Crime Commission, November 21, 1929, pp. 1394, 1396.
} 
custody, and the labor turnover in state prisons is consequently reduced; in most states, a sentence of one year or more usually means commitment to a state institution. ${ }^{1}$ Gill says that at the best one may reasonably expect prison shops to be two thirds as efficient as outside shops. ${ }^{2}$

Industrial inefficiency is the burden of one whole chapter in the Report of the New York Prison Survey Committee in 1920, a chapter which was based largely upon studies of the prison shops made by men experienced in corresponding lines of business outside. The very discouraging state of affairs was due to obsolete and broken-down machinery, overassignment, high turnover, farcical prisoners' wages, underpaid foremen, too little standardization and specialization within the shops, and lax enforcement of the state-use law requiring public institutions to buy from the prisons. That was over ten years ago. In 1927 a sub-commission of the New York State Crime Commission reported that prison industry in the state was "crippled by the lack of shop facilities and the lack of mechancial adjuncts used in production." ${ }^{3}$

2. Earnings and Expenses of Various Institutions and Prison Systems. The operations of the Alabama

${ }^{1}$ Credit for noting this point belongs to Mr. E. R. Cass, in a letter dated July I, I93I.

2 Loc. cit.

- Report to the Commission of the Sub-Commission on Penal Institutions (Albany 1927), p. 9. 


\section{SHOULD PRISONERS WORK?}

prison system, which include state-account farming and cotton mills and a contract shirt factory, reported net earnings of $\$ 3,269,099$ for the quadrennium ending September 30, 1926 , during which four coal mines were also operated with prison labor. ${ }^{1}$ In the next four years the state closed the mines and took over the care of misdemeanant convicts from sixty-four of its sixty-seven counties-two steps which reduced the net earnings of the Convict Department to $\$ 1,09 \mathrm{I}, 479 .^{2}$ This was the amount remaining after paying all operating expenses of the various prison units and the State Board of Administration for the years 1926-30; it is far in excess of the net earnings claimed by any other prison system in the country.

In the year ending December 31, 1926, the Louisiana prison system received (from sources other than appropriations) $\$ 1,557,715$ and paid out $\$ 1,522,062$ for maintenance, additions, improvements, and all other expenditures. ${ }^{3}$ Thus $\$ 35,653$ must represent profit on the operations of the penitentiary plantations.

For the four-year period ending June 30,1928 , the Mississippi prison farms showed an operating profit of $\$ 727,644^{4}$ For a similar period ending December 31, 1928, the North Carolina prison

1 State Board of Administration, 2uadrennial Report (I922-26), p. 117.

${ }^{2}$ Idem, Quadrennial Report (1926-30), p. 159.

${ }^{8}$ Prisoners: 1926, pp. 136-7.

I 1929 Handbook, p. 526. 


\section{COSTS, WAGES, AND PROFITS 237}

system reported a net profit of $\$ 215,44 \mathrm{I} .^{1}$ Its operations include farming, road work, quarrying, furniture making, and other lesser industries.

The South Carolina Penitentiary realized a profit of $\$ 2,927$ in 1927 and of $\$ 4,176$ in 1928 , but in 1929 took a net loss of \$10,168, which was due to floods on the farms and business depression affecting the furniture factory. ${ }^{2}$

Tennessee operated its two penitentiaries profitably, with net earnings of $\$ 143,786$ in I $925-26$ and $\$ 266,697$ in $1927-28 .^{3}$ One of the two is a mining prison. West Virginia (for which we also know per capita figures) had an operating surplus of $\$ 24,569$ in the fiscal year ending June 30 , $1927 .^{4}$

The institutions just discussed have been as a rule entirely self-supporting by means of well-organized industries. The New Castle County Workhouse at Wilmington, Delaware, is also self-supporting, but the receipts from two farms and a shirt contract are not the chief iter. in its income. In the year ending November 30, 1928, the net profit on one farm was $\$ 282$ and on the other $\$ 466$; the contract brought in $\$ 31,074$, and board for prisoners, charged to

1 The State's Prison, Biennial Report (1927-28), p. 5 .

${ }^{2}$ Annual Report of the Board of Directors (I927), p. 6; ibid. (I928), p. 5 ; ibid. (1929), p. 6.

${ }_{3}$ Figures obtained from data given by Department of Institutions, Biennial Report (I924-26), pp. 296-33I; ibid. (I926-28), pp. 322-56.

4 Jg29 Handbook, p. 986. 


\section{SHOULD PRISONERS WORK?}

the three counties of the state and to the Federal Government, amounted to \$II2,949. Thus board is seen to be the largest factor in the operating gain of $\$ 16,831$. When we recall that this institution serves as state prison, county workhouse, and city jail, its showing is decidedly creditable, contract or no contract. ${ }^{1}$ In I929, however, the operating surplus was reduced to $\$ 3,629$ and in 1930 there was a deficit of $\$ 18,335$; contract revenue decreased from $\$ 45,608$ the one year to $\$ 37,797$ the next. ${ }^{2}$

These financial achievements are distinctly exceptional, considering the country as a whole. So far as we can discover, no other penal institution with the exception of the Minnesota State Prison showed a surplus in the period from 1925 to I928. (Available data on the Arkansas Prison System are insufficient to determine its financial status.) The laundry of the Vermont State Prison and House of Correction for Women earned all but $\$ 1,063$ of the institution's "total living expenses" in $1929,{ }^{3}$ while the Virginia State Farm came within $\$ 4,300$ of covering its operating costs in I928.4

But the Texas Prison System offers an example of the difficulties which sometimes surround the attempt to make farm prisons pay. The Peni-

1 Reports of the Board of Trustees (1927-28), pp. 27-8.

Ibid. (1929-30), pp. 7-9, 23-4.

3 Sarah N. Cleghorn and Dorothy Canfield Fisher, "Miss Ross' Girls," Survey, LXVI (I93I), 431.

Ig29 Handbook, p. 953. 
tentiary owns twelve farms in addition to the central receiving station. In I928 six of the farms showed a profit and six a loss, and the net gain of $\$ 79,97$ I from the six was insufficient to prevent a total operating deficit of $\$ 396,036$. The loss in farm revenue seems to have been due to bad weather resulting in a poor grade of cotton, and to low prices on cotton and cane. ${ }^{1}$ The next year, 1929, floods and hailstorms destroyed crops wholesale, so that only two farms showed a profit, and one of these was rented to a private party, not operated by the penitentiary. The total operating loss on all units, including the central prison, was $\$ 1,442,6250^{2}$ The huge business venture which these thirteen units represent, involving over five thousand prisoners and requiring many civilian employees, is subject to all the dangers and risks of any private project and hampered by having to refer to the legislature for permission and capital to make needed changes in the system, such as disposing of disadvantageously situated farms, purchasing new farms, and establishing new industries at the central prison.

The reports of many prisons, in one state after another, tell of varying degrees of success in the attempt to make ends meet. In 1928 the total expenses of the Massachusetts State

1 Texas Prison Board, Annual Report (1928), pp. I, 4.

2 Idem, Annual Report (1929), pp. B-3, D-3. 


\section{SHOULD PRISONERS WORK?}

Prison came to $\$ 362,575$, including repairs, but not including industrial expenditures, and the net industrial income was $\$ 212,702$, or 59 per cent of the prison expenses. ${ }^{1}$ The total expenses (including repairs and replacements) of the Rhode Island State Prison and Providence County Jail in 1929 were $\$ 220,909$, and the gross earnings from shirt shop, farm, and print shop were $\$ 185,028$, or 84 per cent of expenses. ${ }^{2}$ The net earnings from industries in Auburn Prison (New York) were $\$ 247,085$ in the year ending June 30, I928, according to the State Commission of Correction; ${ }^{3}$ the "gross cost" for the same year, according to the I929 Handbook, was $\$ 563,848 ; 4$ earnings were thus equal to 48 per cent of prison costs. Figures obtained in the same way for Clinton Prison show that earnings amounted to Io per cent of prison costs; for Great Meadow Prison earnings were I per cent of costs, and for Sing Sing they were 2I per cent - still referring to the fiscal year ending June 30,1928 , and taking net earnings from the Second Annual Report of the Commission of Correction and "gross cost" from the I929 Handbook. ${ }^{5}$

In the year ending May 3I, I928, the Eastern Penitentiary (Pennsylvania) expended $\$ 655,659$

${ }^{1}$ Commissioner of Correction, Annual Report (1928), pp. I 56-8.

2 Annual Report (I929), pp. 8, 30-2.

3 Second Annual Report (1928), p. I9.

P. 643 .

- Pp. 670, 680, 712. 
on maintenance, repairs, and upkeep (no new construction included), while the total sales of the industries conducted by the Bureau of Restoration amounted to $\$ 243,780$. $^{1}$

It cost $\$ 98,368$ to maintain the Georgia State Prison Farm in 1928, including all expenses but those of the office of the Prison Commission, and the estimated sales value of farm crops raised was $\$ 55,453$, or 56 per cent of the costs. ${ }^{2}$ The total prison expenses of the Maryland Penitentiary, including general repairs but no new construction, were $\$ 372, \mathrm{I} 72$ in the year ending September 30, 1928, and the total net industrial income was $\$ 285,999$, or 77 per cent. $^{3}$ For the Maryland House of Correction, total prison expenses were $\$ 253,427$ the same year and net industrial income was $\$ 166,362$, or 66 per cent. ${ }^{4}$ The "gross cost" of operating the Oklahoma State Reformatory in the year ending June 30, I928, was $\$ 199,656$ and the net industrial profit was $\$ 60,790$, or 3 I per cent. ${ }^{5}$

The Illinois State Penitentiary spent $\$ 1,356,464$ in 1929 , including $\$ 262$, 199 for permanent improvements - i.e., the new prison; ${ }^{6}$ according to a schedule furnished us by the Auditor

1 Annual Report (I928), pp. 27-8.

2 Prison Commission, 2nd Biennial Report (1927-28), pp. 20, 22, 24-7.

${ }^{3}$ Board of Welfare, 6th Annual Report (1928), pp. 21, 25, 26.

4 Ibid., p. 70.

${ }^{6}$ Ig29 Handbook, p. 783.

${ }^{6}$ Department of Public Welfare, Annual Report (I929), p. 381. 


\section{SHOULD PRISONERS WORK?}

of Public Accounts, ${ }^{1}$ the net industrial income was $\$ 26,050$, or 2 per cent of the total expenditures. Figures for the Southern Illinois Penitentiary obtained from the same sources show total expenses of $\$ 54 \mathrm{I}, 334$ and net industrial income of $\$ 60,275$, or I I per cent. Total prison expenses of the Indiana State Prison in the year ending September 30, 1928, were $\$ 5$ 19,029, including $\$ 96,736$ for repairs, equipment, improvements, new construction and expenses of the Pardon Board; net industrial income amounted to at least $\$ 44,739$, and probably more - the figures are incomplete. ${ }^{2}$ In the two years ending June 30,1928 , the Iowa State Penitentiary spent $\$ 843,729$, including $\$ 53,139$ for new construction, new equipment, and repairs; the net loss on its industrial operations was, as far as we can gather, $\$ 4 \mathrm{I}, 555^{3}$ The Kansas State Penitentiary spent $\$ 673,447$ in the fiscal year 1928, including $\$ 94,047$ for improvements and repairs, and the net industrial income was $\$ 59,755$, or 9 per cent. ${ }^{4}$ The total expenses of the Ohio Penitentiary in 1928 were $\$ 1,070,483$, including $\$ 197,024$ for repairs and improvements; the net profits of shops, farm, and brick plant amounted to 43 per cent of the cost, or $\$ 460,817.5$

\footnotetext{
1 In a letter dated September 30, 1930.

- Annual Report (1928), pp. 13, 23-38.

Forty-third Biennial Report (1927-28), pp. 28, 31-3.

- Twenty-sixth Biennial Report (1927-28), pp. 34, 43.

- Department of Welfare, 7th Annual Report (I928), Table I, facing p. 448; pp. 485-7.
} 
In the fiscal year I927-28 the South Dakota Penitentiary spent $\$ 177,781$ for all expenses, and the net profit from its twine plant and farm came to $\$ 5,833$, or 3 per cent; the year before, industrial profits were equal to 15 per cent of total expenses, including the cost of a new boiler. ${ }^{1}$ The Wisconsin State Prison was more successful in 1927-28: its total expenses, including $\$ 17,496$ for improvements, structures, and equipment, came to $\$ 358,744$, while the total net industrial profit was $\$ 176,294$, or 49 per cent. $^{2}$

San Quentin Prison made a net profit of $\$ 42,362$ from its industries in $1925-26$, which was 5 per cent of the total expenses of $\$ 847,056$ (including \$143,3I9 for "additions and betterments"). ${ }^{3}$ In $1927-28$ an item of $\$ 210,220$ for new construction swelled the total expenses to $\$ 1,050,056$ but the I929 Handbook does not specify whether the earnings of $\$ 49,935$ ( 5 per cent of $\$ 1,050,056)$ were gross or net or that they were from industrial sources only. ${ }^{4}$ The Idaho State Penitentiary derived $\$ 66,809$ from its shirt contract and $\$ 10,339$ from other industries in the two years ending November 30 , I928, making a total of $\$ 77,248$; this is 30 per

1 Board of Charities and Correction, 20th Biennial Report (1927-28), pp. $45-7,49,50,66-7$.

2 Twenty-third Biennial Report (1927-28), pp. 44, 46, 48, 50.

3 State Board of Prison Directors, Biennial Report (1925-26), pp. 88-9.

4 P. 165.

s.P.w. -17 


\section{SHOULD PRISONERS WORK?}

cent of the total expenses, $\$ 225,246$, of which $\$ 25,733$ went for improvements. ${ }^{1}$ The garment factory of the Montana State Prison was operated at a loss its first year, ending June 30 , I928; subtracting this loss from the net profits on ranch products, there was left the sum of $\$ I I, 827$ to be applied against prison expenses totalling $\$ 168,059$ - including repairs, etc., and the value of produce used. Thus the net industrial profit was 7 per cent of the prison expenses. $^{2}$ The net profits on the brick and lime plants of the New Mexico State Penitentiary for the fiscal year I927-28 were $\$ 17,757$, or Io per cent of the total prison expenses of $\$ 172,842$, which included $\$ 20,917$ for repairs and new construction. ${ }^{3}$ In the two years ending September 30, I928, the Oregon State Penitentiary's profits from its flax industry and other undertakings were \$II2,6I9, including the value of products on hand but not sold; this was $3^{I}$ per cent of the total prison expenses, including repairs and capital expenses$\$ 368,4990^{4}$ In approximately the same period the Utah State Prison made $\$ 4,994$ from its overall factory, or 3 per cent of the amount necessary to cover all expenses including repairs and improvements - \$162,022. ${ }^{5}$ The Wyom-

\footnotetext{
${ }^{1}$ Biennial Report (1927-28), pp. 6, 16-17, 20, 29.

2 Twenty-sixth Biennial Report (1927-28), pp. 4-5, 17, 21-4.

${ }^{3}$ Report (1928), pp. 8-10.

- Fourteenth Biennial Report (1927-28), pp. I9-21.

- Biennial Report (1927-28), pp. 10-16, 36.
} 
ing State Penitentiary received $\$ 47,792$ (of which $\$ 900$ was for drayage) from its garment contract in the year ending September 30, 1928 ; this was equivalent to 44 per cent of the total expenses of $\$ 107,795$, including repairs and improvements. ${ }^{1}$

It is plain that the great majority of American prisons not only fail to meet operating costs but require heavy annual appropriations. As one observer puts it, only the southern states "expect their industrial prisons to be selfsupporting, in strange contrast to the usual expectation in the North that the prison is bound to lose money." 2

But large profits are secured at a price. There is a danger that the prisoner will be considered as merely so much man-power, not as an individual who needs study, care, and training for responsible life. In studying conditions in southern prisons one cannot avoid the impression that profits are the dominant consideration, that the farms and road camps are manned by what is practically slave labor, and that the racial situation makes this possible; "the work seems to be based on the idea that the state is justified in getting every ounce of work out of a man that can be got, without any

\footnotetext{
${ }^{1}$ State Board of Charities and Reform, Biennial Report (1927-28), pp. 56,138 .

2 William B. Cox, in American Prison Association, Proceedings (1928), p. 213 .
} 


\section{SHOULD PRISONERS WORK?}

thought of the work doing him any good or affecting his condition after release."1

This attitude is implicit in many of the official reports. The superintendent of the Mississippi prison plantations, in recommending that the legislature consider some needed reforms such as classification, segregation, education, and vocational training, remarks that "of course it is not going to be possible to make such a financial success of the Mississippi State Penitentiary, when segregation, classification and education have been installed."2

It is not the system of employment in itself which makes possible the profits earned by some of the southern prisons, but a combination of local conditions and good business management, coupled with some disregard for the prisoner's needs. There is a notable tendency in the South to use inmates as guards and to economize in housing, thus reducing prison costs to a low figure. We must remember, too, that labor and manufacturing interests are not quite so strong in the South and there is less opposition to the sale of prison products than in the more industrialized North. It is also probably true that the southern states are not in a position to support their prisons out of general income derived from taxation. To a

1 Ibid.

2 Biennial Report (1928-29), p. 21. 
certain extent, necessity has compelled southern prisons to reduce idleness to a minimum and to make a good financial showing.

In concluding this discussion of profits, we wish to remind the reader that an institution's showing, whether good or bad, must be considered in the light of the prevailing prison wage system. Just how does the fact that no wages - or pitifully small wages - are paid affect the profitableness of the venture? There are of course other very vital factors - such as restrictive legislation and the business judgment of those charged with the conduct of the enterprise - which materially influence the results, but we must not lose sight of the fact that prison industries today rest very largely on what may be termed slave labor.

It is also essential to point out that in this discussion of profit it has been impossible to separate penological costs from industrial costs. Society should bear a part of the burden, and more attention should be given to deciding what this part ought to be. In a sound system of accounting the proper separation would be made and we should then be in a position to judge the industrial side more fairly and to relate it to wages and the economic training of the prisoner. 


\section{VII}

\section{WHAT WORK HAS BEEN FOUND FOR PRISONERS?}

Everything which has been said in the preceding chapters obviously indicates that the choice of prison industries and occupations has not been made in accordance with the dictates of a scientific penology, which demands that the job be fitted to the man, not the man to the job. In this chapter we shall discuss the industries (no matter how selected) which are carried on in American prisons today. What work are our prisoners actually doing and what kind of jobs are available when a man is committed to a penal or correctional institution?

In Local Institutions

(Jails, Workhouses, Houses of Correction)

The small size of most local jails and workhouses, the limited resources of the governmental unit responsible for their management, the short terms of the inmates, the outworn plants with which most jailers are saddled all contribute to the difficulties of employing the prisoners. Add the fact that detention, or 
court, prisoners cannot be forced to work, yet must be cared for and often need closer guarding than sentenced prisoners, and one understands why most sheriffs and jailers give up the employment problem as a bad proposition, if it ever occurs to them to tackle it at all.

We have already pointed out that exceptions to this state of affairs are the county road camps of the South, which are apparently maintained for the express purpose of exploiting to the utmost the labor of all able-bodied prisoners.

1. Jobs Now Available. In Chapter II we mentioned the principal kinds of work done by those prisoners reported as employed in our survey of county and municipal institutions. Now we wish to supplement that general view of jail employment with more detailed data concerning certain localities - bits of information brought together from the reports of supervisory bodies, fact-finding committees and individual investigators. First we shall list (Table XXIV), for the sake of interest and reference, every occupation which we have discovered at any local penal institution.

This group is more comprehensive than one might expect. Here are jobs ranging from the crudest type of manual labor to printing, which involves highly skilled operations. Obviously the presence of such a trade on the list points to the existence of local institutions far superior 


\section{SHOULD PRISONERS WORK?}

TABLE XXIV

TyPES OF WORK IN LOCAL INstitutions

Rock breaking

Road and bridge work

Quarrying

Stone cutting

Coal mining

Construction work

Making cement blocks

Brick making

Farm work

Dairying

Canning

Maintenance jobs

Operating central heating plant

Laundry work

Foundry work

Machine-shop work

Salvaging automobiles

Woodworking

Printing

Upholstering
Preparing rags for rugs

Weaving

Power sewing

Hand sewing

Manufacturing:

Carpets

Mattresses

Clothing and bedding

Shoes

Shirts

Mats

Brooms and brushes

Chairs

Parts of chairs

Other furniture

Willow goods

Reed baskets

Electrical novelties

Miscellaneous arts and crafts products, such as bead work

to the average county jail. As a matter of fact, this list represents every type of institution from county chain gangs to the District of Columbia Workhouse and the Westchester County Penitentiary (New York).

Let us next glance at a few detailed reports and see what work men have to do in the typical jail housing both sentenced and detention prisoners. For example, take some official reports of jail inspections made by representatives of the State Board of Charities and Corrections in Missouri in I925 and 1926. In Boone County the prisoners were employed "around the jail and courthouse."1 In three counties (Cape Girardeau, Jasper, Scott), prisoners were

1 Biennial Report (1925-26), p. 52. 
employed to keep the jails clean. ${ }^{1}$ In three others they were "employed as needed," which presumably means they did maintenance work. ${ }^{2}$

For Oregon we have data on the Lane County Jail only, which received fifty-two sentenced prisoners in 1923: of these, "six were allowed to work off their punishment at the rock crusher, nine were given a certain amount of freedom as trusties, and three were permitted to work for a time at the poor farm"; one was set to work cleaning streets, another did odd jobs at the county park near by and a third "was put to work in the county blacksmith shop." 3

Toledo, Cleveland, and Dayton, Ohio, all have jail farms for their misdemeanants; prisoners at the Dayton farm operate a stone crusher and a laundry as well. ${ }^{4}$

Eight of the jails and houses of correction in Massachusetts have some industrial work for prisoners. At half the institutions this consists of chair caning and the manufacture of chair parts, also the repairing of furniture. One house of correction makes reed baskets and another makes street brooms; another manu-

\footnotetext{
1 Ibid., pp. 53, 56, 61.

${ }^{2}$ Ibid., pp. 54, 57.

"Ruth Dunlop Wheeler, "The Problem of the County Jail," Fournal of Criminal Law and Criminology, XV (February 1925), 624, 626-8.

"Harris R. Cooley, "Good Opportunities for Prison Labor," Annals, XLVI (March 19I3), 92-6; E. V. Stoecklein, "Correction Farm Supplants a City Workhouse," American City, XXIX (1923), I49-5I; C. Russell, "Welfare Farm of the City of Toledo," Ibid., XXIII (I920), 610-12.
} 


\section{SHOULD PRISONERS WORK?}

factures shoes and shirts and cuts curb stones; two others give their men farm work. ${ }^{1}$

Most misdemeanant prisoners in New Hampshire do farm work, inasmuch as the houses of correction and all but two of the jails are located at the county poor farms. ${ }^{2}$

Connecticut has ten county jails, concerning conditions in which the Department of Public Welfare issues a tabular summary; ${ }^{3}$ the following quotations are from the column headed "Work":

Hartford County Jail.- "Chair work for men; sewing and laundry work for women."

New Haven County Jail._- "Woodwork in factory for men; sewing and kitchen work for women."

New London County Jail No. I.-" "Miscellaneous work for men; kitchen work for women."

New London County Jail No. 2.- "Odd jobs and kitchen work for men; sewing for women."

Fairfield County Jail No. I.- "For men, outside work, [the making of] cement blocks, electrical novelties; for women, kitchen and laundry."

Fairfield County Jail No. 2.- "No work, only short term prisoners here."

Windham County Jail.- “Men work on jail farm of 320 acres."

Litchfield County Jail. - "Women do sewing. Outside work for part of the men."

Middlesex County Jail.- "Farm work and odd jobs for men; women work in kitchen."

Tolland County Jail.- "Farm work and odd jobs for men; housework for men and women."

${ }^{1}$ Letter from Deputy Commissioner of Correction, June 20, 1930.

2 State Board of Charities and Correction, I7th Biennial Report (1927-28), pp. 68, 71.

In its Report (I927-28), pp. 44-5 ff. 
New York jails are inspected regularly and detailed reports are published by the State Commission of Correction. The Orange County Jail at Goshen had twenty-nine prisoners on March I5, I928, twenty-five of whom were serving sentence. It was reported that sentenced men were employed as trusties at work "about the county buildings and during the summer at farm work. Sentenced females assist in the kitchen."1 At Newburgh, Orange County has a branch jail housing an average of eighteen prisoners, who in March, I928, were employed "only at trusty work about the county buildings," ${ }^{2}$ but by the following August prisoners had been employed to repaint the entire interior of the jail and they had also... painted the interior of the basement of the Court House, washed down the walls and ceiling of the entire building, including the court room, painted the roofs and gutters of the buildings, as well as the four blocks of fence surrounding the jail and Court House, constructed $75^{\circ}$ feet of concrete curbing and I,000 square feet of concrete road, a macadam drive around the buildings and set out I4 trees. ${ }^{3}$

At the Otsego County Jail (Cooperstown), "sentenced prisoners are employed on the county farm, cutting ice, and some perform work of a trusty nature about the buildings and grounds." 4 Work "of a trusty nature" means

${ }^{1}$ State Commission of Correction, and Annual Report (1928), p. 268.

2 Ibid., p. 270.

${ }^{3}$ Ibid., p. 27 I.

4 Ibid., p. 275. 


\section{SHOULD PRISONERS WORK?}

caring for the lawns, etc., in season. Similar work was done at the Rockland County Jail, the Sullivan County Jail, and the Yates County Jail. ${ }^{1}$

Oneida County has two jails and a jail farm. The farm employs eight to twenty prisoners, who also do such jobs as hauling coal for adjacent county institutions. ${ }^{2}$

Broome County has both a jail and a farm. The jail is located in the city of Binghamton and prisoners have nothing but the usual "trusty work about the jail and grounds," ${ }^{3}$ but the farm is a modern development, with many improvements such as a concrete milk house and refrigerating plant - built by inmate labor. Farm products worth $\$ 22,682$ were recorded for the year ending October 3I, I927, and much of the fresh produce, meats, and milk went to the Binghamton jail, the County Home, and the Tuberculosis Hospital. "Some milk in excess of county department requirements was sold," 4 i.e., to the public.

It seems obvious that most New York jails located in cities and towns have little real work to offer. Another feature of the situation brought out by the preceding quotations is the necessity of keeping many prisoners shut up in

1 State Commission of Correction, and Annual Report, pp. 284, 301, 316.

2 Ibid., pp. 257-8.

3 Ibid., p. 205.

Ibid., p. 206. 
idleness because the jailer or sheriff dares not give to any but "trusties" the degree of freedom required for the work available. In other words, county institutions do not seem to have the type or size of staff needed to handle all sorts of prisoners safely at the kinds of work which might be developed in and about the jail. The institutions just cited, with the possible exception of the two jail farms, probably could not offer the more worthwhile occupations on our complete list. Such things as construction work must ordinarily be left to institutions like the Erie and Westchester county penitentiaries, which board jail prisoners from other counties and thus exercise the function of regional state jail farms. Here is a day's work sheet for the Westchester County Penitentiary, ${ }^{1}$ in September, 1930:

Barbers........... 5 Plumbers.......... 6

Blacksmith........... I Reflecting Room...... I

Carpenter shop....... 4 Shoemaker.......... I

Dairy............. I4 Tailors............. 10

Farm............. 8 Teamsters.......... I0

Firemen........... II Butchers........... 8

Garbage............ 2 Bakers............ 3

Janitors............ I6 Garage........... 9

Kitchen........... I6 County Home........ 2

Office............. 2 Construction......... I4

Painters............. 8 Roads and grounds.... 34

Bertillon Room....... 3 Flowers and lawns..... I0

Brought forward....198

${ }^{1}$ Letter from Superintendent, September 8, 1930. 
Poultry............ 5

Hospital............ 3

Library............. 2

Laundry........... I2
Unemployed......... 16

Sick............... 4

Received............. 2

Discharged.......... 4

Total............246

Even this relatively large institution, which takes only sentenced prisoners, reports 7 per cent idle and has to put a disproportionate number of men in the gangs detailed to keep the place in order.

Turning now to Pennsylvania, we find that eight counties (Berks, Cambria, Cumberland, Delaware, Fayette, Franklin, Lehigh, York), employ prisoners at road work and other public works such as bridge making and construction. Five of the eight pay for roadwork in some way with money, food, tobacco, or "good time."1 It does not follow that prisoners in these counties are used on road work continuously, but the commissioners do make a practice of so employing them sometimes. In I928 Beaver County also was reported as employing some of its sentenced prisoners on road and bridge construction. ${ }^{2}$

Nine Pennsylvania counties (Bedford, Berks, Cambria, Delaware, Montgomery, Somerset, Tioga, Wayne, York) employ prisoners at farm

1 Leon Stern, The County Prison of Allegheny County (Philadelphia, 1930), p. 34 .

The Treatment of Adult Offenders and Children by the Courts of Beaver County, Pennsyloania (Philadelphia, I928), p. 34. 
work and two more (Green and Lycoming) are making efforts to establish prison farms. Berks and Delaware already have special prison farms and Montgomery is developing one. Somerset County works prisoners in a small coal mine at the county poor farm. ${ }^{1}$

The following work sheet for May I929 at the Delaware County Jail (Media) ${ }^{2}$ shows what can be done when a county makes an honest effort to employ its jail prisoners:

45-50 men wrecking old houses next the jail and cleaning old bricks.

25-30 men planting and clearing at Broad Meadows Farm (new prison farm).

I6 men cutting, sorting, and balling rags for rugs, Media.

8-10 men on the Lindbergh Bridge, Clifton.

3-5 men working on the courthouse lawn.

2 men assigned to outside work, jail.

2 men assigned to yard work, jail.

IOI-I I 5 men employed, out of I 40 detained at the time.

Philadelphia and Pittsburgh offer two examples of large municipal institutions. The Philadelphia County Prison is an old, overcrowded institution with far too little work to go around. In I929 it reported the discharge of 2,906 sentenced prisoners, whose occupations in prison had been as follows:

1 Stern, op. cit., p. 34 .

${ }^{2}$ Leon Stern, The Treatment of Adult Offenders and Children in Delaware County, Pennsylvania (Philadelphia, I930), p. 66. 


\section{SHOULD PRISONERS WORK?}

School

Plumber........... I5

Scrubber............. 787

Printer............ I I

Sewing........... 85

Shoemaker.......... $3^{2}$

Stocking maker....... 12

Tailor.............. $3^{2}$

Tinsmith............ II

Weaver............ I09

Upholsterer.......... 37

Hostler............ 2

Laborer............. 23I

Laundry........... 306

Librarian............ 2I

Nurse............ 35

Painter............ 24

Plasterer........... 2

Runner............ 59

Barber............ 23

Baker............. 2I

Brush maker........ 3

Bricklayer........... I

Blacksmith.......... 5

Butcher........... I

Carpenter........... 7

Cook.............. 145

Firemen........... I3

Gardener........... 28

Unemployed........ 835

Total..........2,906

This does not mean that there were 306 laundrymen at any given time, or I 45 cooks, or 37 upholsterers, but that of the 2,906 discharged from sentence during the year, 306 had been employed at laundry work, I 45 as cooks, and so on.1

The Allegheny County Workhouse, which serves Pittsburgh and boards prisoners from adjoining counties, maintains a broom factory, a carpet factory, a chair factory, a laundry, and an upholstering shop, besides a farm. Dr. Liepmann dismissed its industries in a few words: "The provisions for work are for the most part antiquated, and not worth a detailed description."2 But Professor Harry Elmer

1 Philadelphia County Prison, Summary of Activities of the Board of Inspectors (1929), p. 17.

"American Prisons and Reformatory Institutions; a Report," Mental Hygiene, XII (I928), 272. 
Barnes has only praise for this "admirable industrial farm," which he calls "a model institution of its kind." 1 Its significance lies in the fact that it shows how a larger institution, serving more than one county, can improve over the small jail both in the matter of abolishing idleness and in substituting jobs at least better than the "maintenance work" typified by the New York reports already quoted.

The District of Columbia Workhouse is a distinctly superior institution, not at all in a class with the ordinary jail. It derives unusual advantages from being under the same management as the District of Columbia Reformatory near by, yet we see how the nature of its population and their short terms ${ }^{2}$ limit its industrial undertakings in extent and variety:

\section{TABLE XXV}

Occupational Opportunities in District of Columbia Institutions Reformatory Group Workhouse Group

\begin{tabular}{lll}
\hline Foundry & Mattress shop & Farming \\
Auto repair shop & Printing & Canning \\
Tag shop & Brooms & Clothing
\end{tabular}

Brick plant
Machine shop
Farming

The District of Columbia Jail, in Washington itself, receives both sentenced and detention prisoners, but the number of sentenced prisoners

${ }^{1}$ From The Evolution of Penology in Pennsyloania, p. 402. By Harry Elmer Barnes, Copyright, 1927. Used by special permission of the publishers, The Bobbs-Merrill Company.

2 Out of 2,033 sentences, 1,053 were for ten days. Board of Public Welfare, Annual Report: D. C. Penal Institutions (I929), p. 24.
s.P.w.-18 


\section{SHOULD PRISONERS WORK?}

kept there is well below the number transferred to the Workhouse. The jail inmates operate a central heating plant and laundry. ${ }^{1}$

The advantages of good organization and trained management are also evident in the Detroit House of Correction and the Milwaukee House of Correction, the one maintained by the city of Detroit and the other by the county of Milwaukee. Each has in the past operated a chair factory as its chief industry and sold goods in quantities large enough to bring in substantial revenues. ${ }^{2}$ Both will be forced by the results of the Hawes-Cooper Bill to change industries completely or at least to curtail this type of work. ${ }^{3}$ Both have farms, and the Detroit institution maintains a machine shop, a print shop, a salvage department for retrieving materials from old automobiles and machinery, a laundry, a cannery, and a sewing department. One of the farm products is maple syrup. This variety of employment contrasts strikingly with the two occupations reported for Michigan jails - road work and the making of cement blocks. ${ }^{4}$ A similar contrast is evident in Indiana, where prisoners from one of the eighty-nine county

1 Ibid., pp. 4-5.

${ }^{2}$ Milwaukee County House of Correction, Annual Report of Wm. H. Momsen, Inspector (I929), pp. 7-8. Detroit House of Correction, 66th Annual Report (1926), p. 8I; 68th Annual Report (1928), p. 45.

I Idem, 6oth Annual Report (I929), p. 7; letter from Inspector of Milwaukee County House of Correction, November 1 2, 1930.

4 Julia K. Jaffray, The Michigan Fails, MS copy, p. 3. 
jails were used "in redecorating a number of the county buildings." 1 Inmates of the other eighty-eight jails have nothing in particular to do, while men with a sentence of more than thirty days must be sent to the Indiana State Farm. This institution is able to carry on an ambitious industrial program, operating (besides the farm itself) a quarry, a brick plant, a furniture factory, a willow goods industry using willows grown on the place, and a shirt factory. Much construction work is done. ${ }^{2}$

A jail farm of this type is on the borderline of our classification of state and local institutions, and the industries which it is able to maintain resemble those which we shall discuss presently.

2. Jobs That Might Be Done. Any discussion of jobs for jail prisoners is always subject to the fundamental limitations imposed by short terms and high turnover. It nevertheless seems pertinent to run over the possibilities, such as they are.

Five or six years ago Joseph F. Fishman, once inspector of jails in which Federal prisoners were confined, made a study of industries suitable for jails. After taking into consideration nearly a dozen factors such as the state laws and local trade attitude concerning prison

${ }^{1}$ Indiana Bulletin of Charities and Correction, No. 182 (May 1930), p. 337 .

2 Fifteenth Annual Report (I9I9), pp. 4-8. 


\section{SHOULD PRISONERS WORK?}

labor, the market demands, and possibility of compensation, and the necessity for work requiring little skill, small space, and inexpensive equipment, he listed sixteen types of work which should prove adaptable for jail use. ${ }^{1}$ Ten of them (scrapping automobiles, road work, laundry work, chair caning, broom making, weaving of rag rugs and carpets, weaving materials for trousers, bead work, basket work, inlay wood work) already appear either specifically or by implication on our list in the early part of this chapter. The remaining six suggestions include bookbinding, and the making of knitted ties and scarfs, lamp shades, hooked rugs, circular and tennis nets, and cocoa fiber mats.

Industries for jails are not an impossibility. The chief need is not for more suggestions as to type of work but for initiative in applying some of the ideas already suggested or in use - also for determined effort to enlarge the units of jail administration and change the sites from city to country.

\section{Jobs in State and Federal Institutions}

(Prisons or Penitentiaries, Adult Reformatories)

The complete list of industries installed in Federal and state institutions at the present time is surprisingly large and varied. We have classified them according to type of product in

${ }^{1}$ American Prison Association, Proceedings (1926), "p. 293. 


\section{KINDS OF WORK}

\section{Table XXVI, while Table XXVII shows the various maintenance and construction trades.}

\section{TABLE XXVI}

\section{Types of Prison Industrial Production}

(State and Federal Institutions)

\section{Farm products}

Cereals

Fodder crops

Truck produce

Orchard crops

Dairy products

Milk, cream,

butter, cheese

Poultry products

Meats, fresh and cured

Canned goods

Sugar (beet and cane)

Flour

Cotton and cottonseed

Flax and flaxseed

Tobacco

\section{Textiles}

Yarns

Blankets (cotton and wool)

Sheets and other bedding

Toweling and cleaning cloths

Cotton duck

Mail bags

Canvas and canvas baskets

Cotton yard goods

Woolen yard goods

Rugs

Flags

Jute bags

Garments

Prison uniforms

Work shirts

Civilian shirts

Overalls

Athletic underwear

Coats

Trousers cotton

Suits duck

Pajamas and nightwear

Dresses, cotton and wool

Bungalow aprons

Aprons

Children's suits
Hospital gowns and supplies

Knit goods

Hosiery

Underwear

Mittens

Fancy work

Quilting

\section{Leather products}

Hides

Harness

Whips

Shoes

Miscellaneous leather goods

Wood products

Lumber

Snow fences

Boxes

Wagons, carriages

sleighs

Window sash, door frames, etc.

Furniture

Chairs

Benches

Tables

Desks

Cabinets

Bureaus

Garden furniture

Reed and fiber products

Chairs

Chair caning

Tables

Hampers

Baskets, trays, stands

Metal products

Foundry

Iron hollow ware

Stoves

Castings of all kinds 


\section{SHOULD PRISONERS WORK?}

TABLE XXVI (Continued)

Wrought iron
Lamps
Andirons
Fire tools
Sheet metal
Furniture
Stamped goods
Auto tags
Highway and street markers
Other tags
Galvanized iron ware
Tin products
Aluminum ware
Wire products
Bed springs

Clay products

Brick

Tile

Pottery

\section{Cement products}

Cement for road building, etc. Building blocks

Culverts
Fence posts and markers

Garden furniture

Coal and coke

Chemicals

Soaps

Paints

Brushes and brooms

Printing and bookbinding

Twine and rope

Machinery

Farm implements

Flax-pulling machines

Miscellaneous

Laundry work

Dyeing

Coffee roasting

Mattresses

Tree nursery work

Novelties

Tire salvage

\section{TABLE XXVII}

Maintenance and Construction Trades

(State and Federal Institutions)

Maintenance
Cooking
Baking
Laundry work
Ice making
Barbering
Library work
Clerical work
Accounting
Upholstering
Motor repair work
Power-plant operation
Maintenance and construction
Plumbing
Tinsmithing

Maintenance

Cooking

Laundry work

Ice making

Barbering

Library work

Clerical work

Accounting

Upholstering

Motor repair work

Per-plant operation

Tinsmithing
Carpenter work

Electrical work

Blacksmith work

Machine-shop work

Pattern making

Masonry

Bricklaying

Painting

Plastering

Steamfitting

Road construction

Grading

Surfacing

Concrete work

Bridge and culvert work 
Thirty-three of the fifty-seven major industries listed by the Commerce Yearbook: $1929^{1}$ are represented in Table XXVI but not all the items on the table are for outside consumption. Add the maintenance occupations, among which are several skilled trades, and it would seem at first glance as though the variety were great enough to provide every prisoner with a suitable job and prevent any possibility of unfair competition with outside industry. But we must not be deceived by the length of the list. No one institution operates more than a small fraction of the total number of trades or industries, and some types of work are necessarily found in every prison. While there are certain general contrasts between different parts of the country, and though here and there a prison will have an industry peculiar to itself, at the same time there is considerable duplication.

Regional differences in types of work are quite interesting. Using the same geographical divisions that have formed the framework for employment and wage data in Chapters II and VI, we may say that in general the prisons of the East and the Middle West are industrialized; southern prisons are divided about equally between factory industries, road work, and farming as an industry; while prisons of the far West have no large farm projects and, with

${ }^{1}$ Vol. I, p. 48. 


\section{SHOULD PRISONERS WORK?}

one or two exceptions, few factories producing in quantity or for outside consumption.

If we study the worksheets given in the 1929 Handbook, we discover that the fourteen western institutions all have farms of some kind, which in four cases are run as productive industries for cash return. Ten of the fourteen have tailor shops, six have shoe shops, four have laundries, two have brick plants - all relatively small and primarily for institutional use; while two have contract shirt shops which together employ about as many men as the shirt shop in the Indiana State Prison. Three prisons have tag shops and three have quarries; Folsom has little industrial work except its quarry. There is one print shop in the whole western group, and the one furniture factory is San Quentin's second most important industry. The jute mill at San Quentin and the flax industry in Oregon are the only large industrial undertakings in prisons of the coast states; both were established to meet particular local needs and to build up state projects. The flax industry supplies seed to farmers, buys the crop, prepares it, and sells the processed flax straw to local plants for manufacture into linen and twine.

Contrast this picture of industrial and farming underdevelopment with the state of affairs in the South, where every man is worked hard 
either on the roads, in the fields, or in the shops. In Arkansas, Louisiana, and Mississippi farming has long been almost the only kind of prison work and money crops are cultivated intensively. A certain tendency to depart from this tradition now appears, inasmuch as Louisiana has a refinery on one of its sugar plantations and has installed both a tag shop and a tile plant. ${ }^{1}$ In Texas twelve prison units out of thirteen are farms, but new industrial buildings are under construction at one institution. ${ }^{2}$ The thirteenth unit now makes shoes, mattresses, and patterns, and does laundry, blacksmith, machine-shop, and foundry work, also printing, but these shops and the maintenance details connected with them employed only about 550 of the state's 4,000 -odd prisoners in 1928. Alabama, Delaware, North Carolina, and Virginia operate both farms and industrial shops for profit. Alabama has mills for spinning and weaving the cotton grown on the prison plantations, and a shop where the cloth is made up into shirts; the closing of its mine prisons in 1928 and the prospect of losing its shirt contract by 1934 have forced an increase in the farming operations. The Georgia State Farm is no profit-making institution, since it cares

1 American Year Book (1929), p. 493.

2 National Society of Penal Information, Neros Bulletin, II (April I93I), 10.

I929 Handbook, pp. 9I I, 9 I 7. 
for only the physical dregs of the prison population, but farming is the principal work available; all able-bodied men are sent to the county road camps. Florida operates poultry and dairy farms, but most of its 2,500 prisoners are in shops or on the roads. Since some of its shops are on the contract basis and will probably have to close, it is planning to expand its farm work. ${ }^{1}$ In Oklahoma, Tennessee, and West Virginia farming is subordinate and is carried on chiefly to supply institutional needs; at the Maryland House of Correction it is a minor industry in connection with the cannery. Only the Kentucky State Penitentiary and State Reformatory and the Maryland Penitentiary do no farming at all; these institutions have various contract and state shops.

Thus the South divides its prison labor between three main types of work (excluding maintenance, which is kept to a minimum): roads, farming, factory production. In no other part of the country are prison farms run on such a large scale. We find in some states a tendency away from farming towards factory industries, but in others which have been more or less industrialized the national situation with respect to prison labor seems to have started a definite trend towards farming on a commercial scale.

1 American Year Book (I929), p. 493. 
We have already said that the prisons of the East and the Middle West were on the whole industrial. By this we mean that few if any of them operate farms primarily as a business, while the majority attempt to make money from factory industries. Only the State Prison at Charlestown, Massachusetts, is without farm or garden of any kind - now that Pennsylvania's two penitentiaries have each an annex in the country - but prison farms in East and Middle West, almost without exception, are operated primarily to provide the institution with produce. Surplus products may be sold to other institutions or on the market, but these sales are not the reason for raising the crops in the first place. On the other hand, forty-two out of sixty-nine eastern and middlewestern institutions covered in the 1929 Handbook report a substantial number of inmates at work in shops producing for outside consumption. Road work has been extensively used as an occupation for state prisoners in Michigan, New Jersey, and New York only, of all this group; New York is expanding its prison road work, but the Michigan camps are now closed.

The Federal institutions all have farms, which, however, cannot be developed on the southern scale as no produce may be sold on the market. Atlanta has its duck mill and makes up mail bags and baskets for the Post-Office Department, 


\section{SHOULD PRISONERS WORK?}

also tents and tent flies, and other canvas products; Leavenworth makes shoes, brushes, and brooms for various branches of the Government, and Alderson has a garment shop. There are no shops at McNeil Island except those needed for maintenance. ${ }^{1}$ Chillicothe operates a brickyard to provide the brick for its new buildings now under construction, while it is soon to operate a foundry for the production of mail boxes and other metal goods. Increasing numbers of Federal prisoners are being transferred to road camps located on reservations or at army posts.

\section{Extent of Road Work as a Prison Occupation}

Inasmuch as the preponderance of road work by prisoners is done in the South, we have collected and tabulated data on this type of labor for all the southern states, adding figures for road work by Federal prisoners and by prisoners in the five other states which have undertaken to use prisoners on the roads regularly or in any numbers. To clarify the rather puzzling situation existing in one or two southern states, we have divided our data first by unit of management - state or county - and then, whenever possible, according to type of offense - felony or misdemeanor; next, by figuring the

\footnotetext{
${ }^{1}$ I929 Handbook, p. 46.
} 
ratio of felony road workers to total felony prisoners, we have obtained some idea of the importance of the occupation in the states using it most extensively. In only two cases was it possible to learn what percentage of the total sentenced misdemeanant prisoners were doing road work. (See Table XXVIII.)

As usual, county data are meager, and are completely lacking for all but seven of the states listed. Florida, Georgia, North Carolina, South Carolina, and Tennessee have each a considerable number of misdemeanants doing road work under county management. In Georgia 69 per cent of all misdemeanants are so employed, and the county road camps also care for 86 per cent of all felony prisoners. In South Carolina, too, the majority of all prisoners, whether felons or misdemeanants, are sent to county road camps. North Carolina, on the other hand, has discontinued county road work very recently, and it remains to be seen whether misdemeanants will in the future be sent to State Highway camps or employed on county farms.

Road work under state management employs large numbers of prisoners (felons only, as a rule) in Alabama, Florida, North Carolina, Virginia, California, Michigan, and New York. Ten per cent of all prisoners in Federal institutions were assigned to road work in July, I93I. 


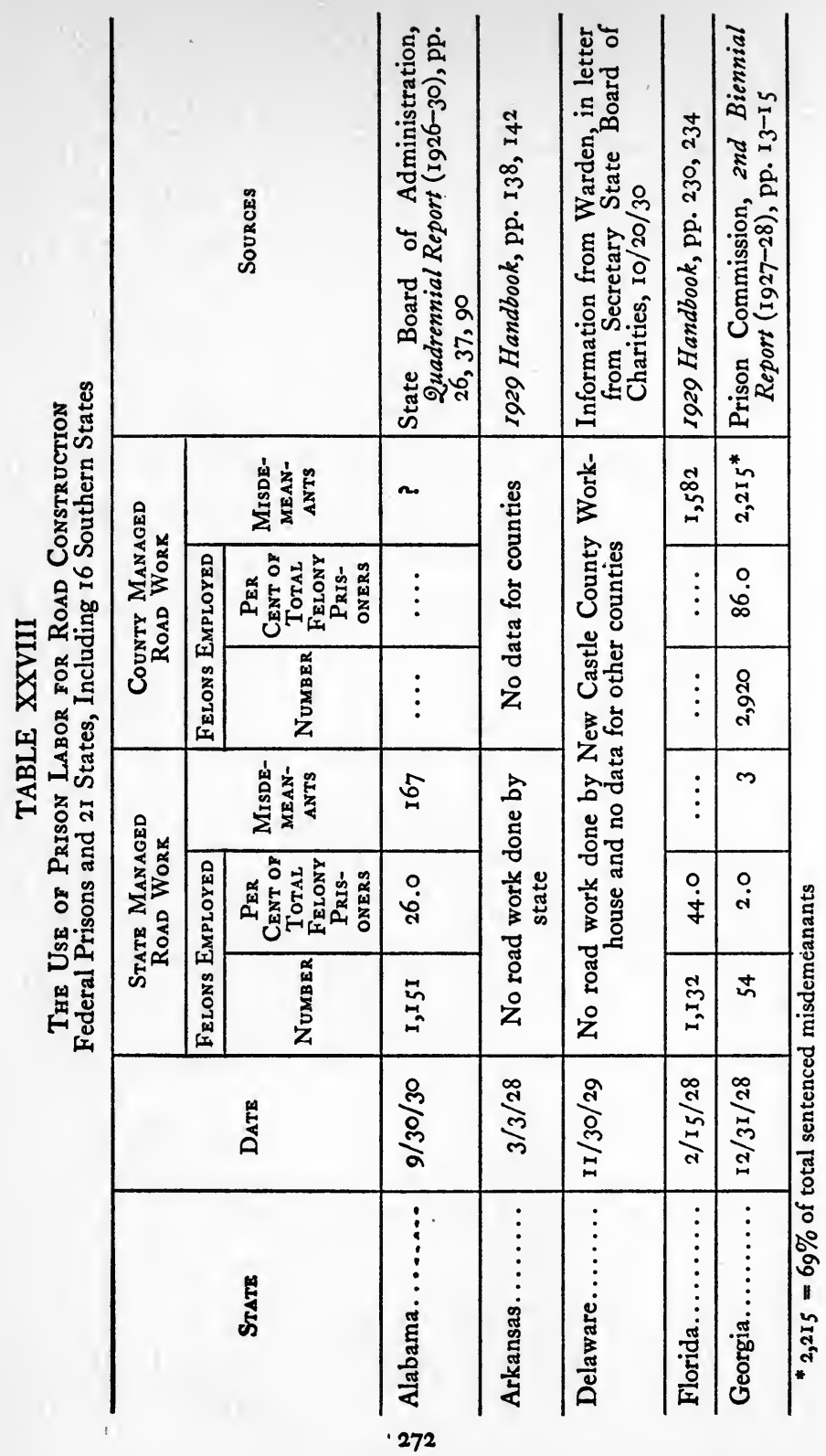




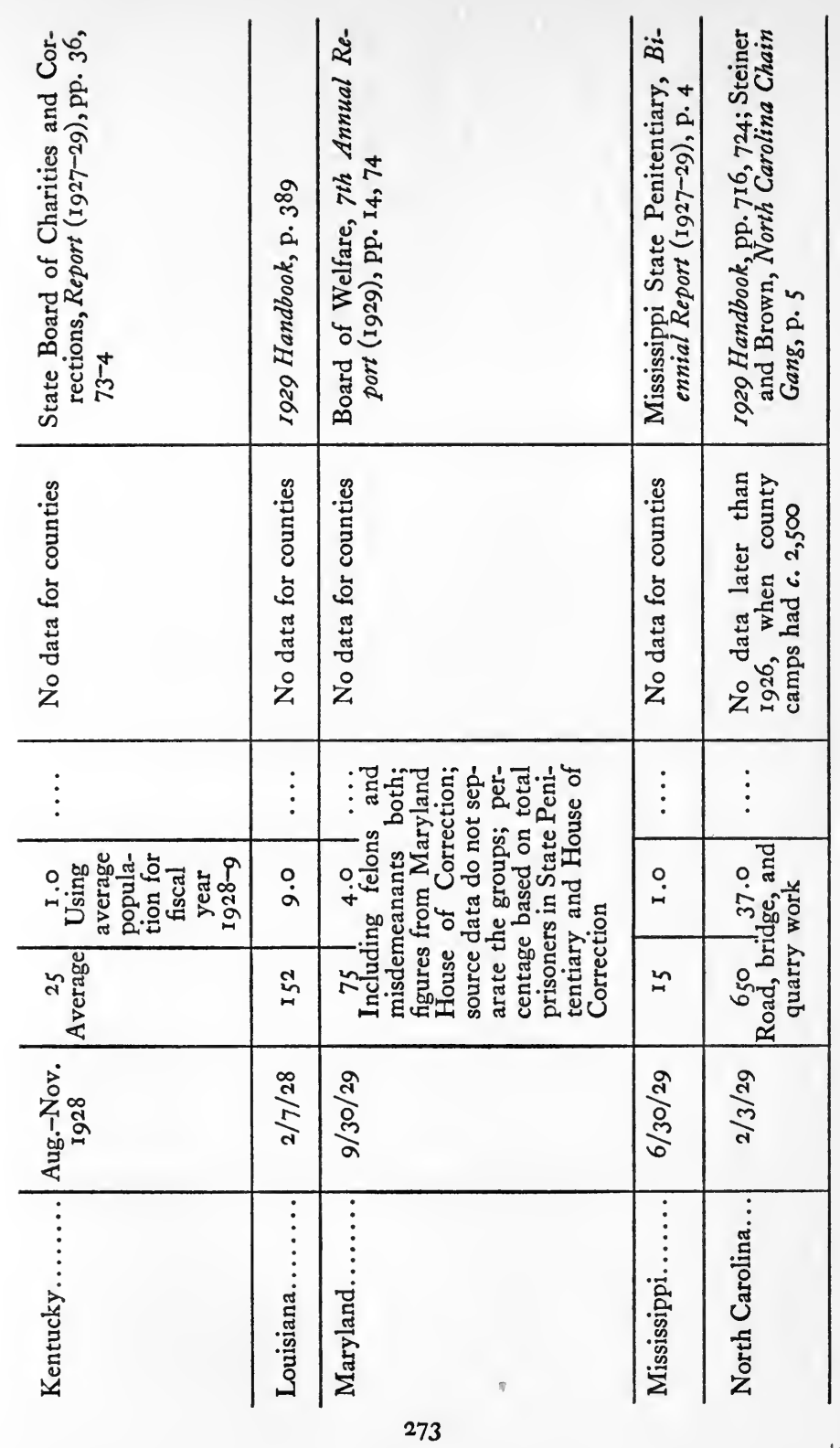




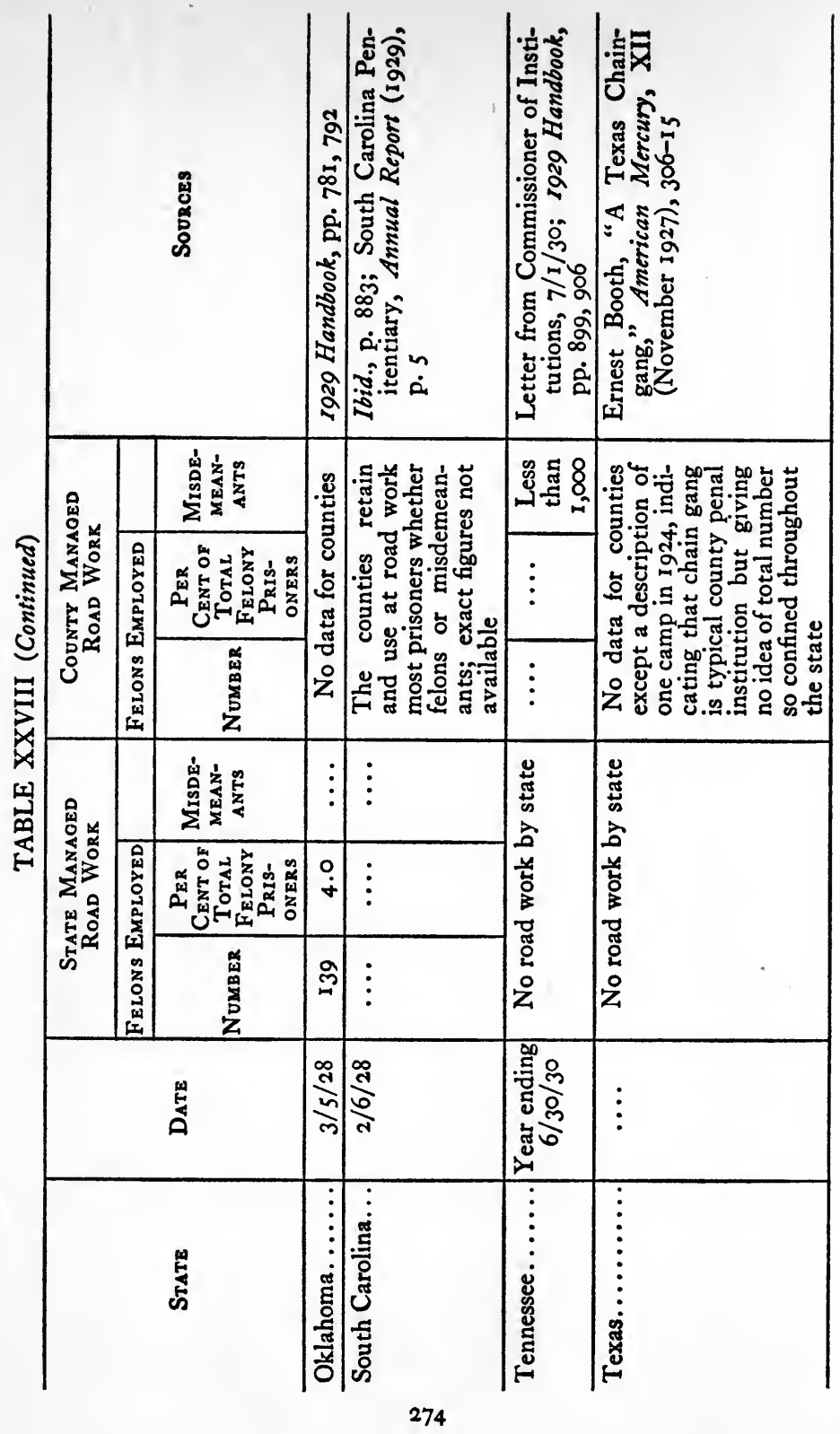




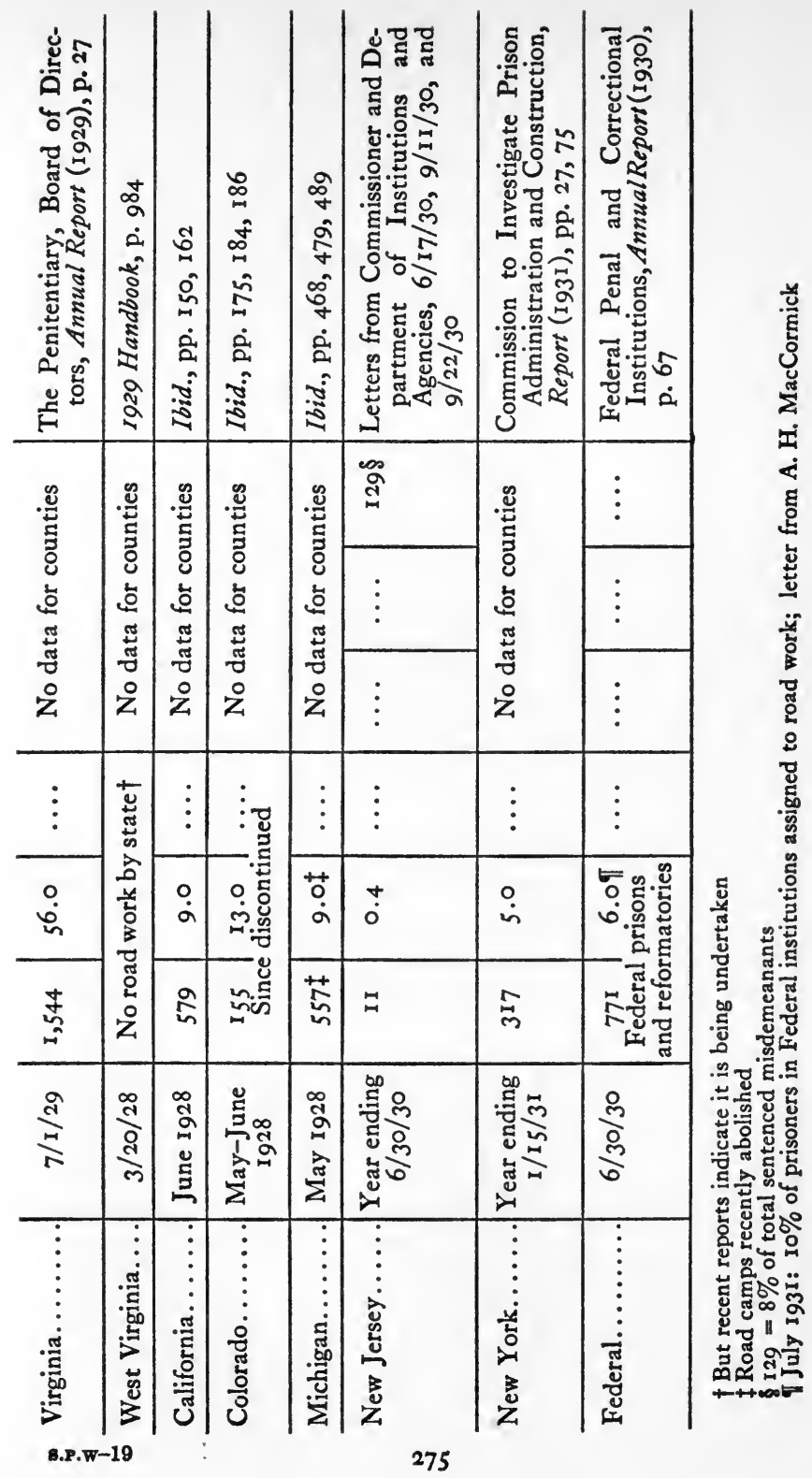




\section{SHOULD PRISONERS WORK?}

How Prison Industries Have Been Selected

Prison industries have grown haphazardly, without any thought concerning the field as a whole. Faced with the problem of employing prisoners, one institution looked around for the most profitable type of work available, while another chose that which was simplest to install and operate. In the last century, individual industries were largely determined by the available contractors. As prison contracts fell into bad repute and state-account management was introduced, the purpose in choosing an industry was largely that of finding something profitable. Thus Minnesota's success with binder twine influenced half a dozen middlewestern states to install twine plants. ${ }^{1}$ Where the state-use system came into vogue as a cure-all for prison competition problems, the individual industries were naturally determined by the state needs which the prison could supply with a minimum of trouble.

The industries which have thus developed in a hit-or-miss manner form the rather imposing list given in Table XXVI. It is on the whole a good list whose chief defect is the concentration already mentioned, a concentration which emphasizes printing and farming, and the manufacture of garments, furniture, shoes, and sheet metal products (including license tags). Far

${ }^{1}$ Convict Labor in 1923, p. 125. 
too many men are thrown into the garment trade especially. Twenty of the forty-eight states maintain shirt shops in their prisons for men, and in most cases these shops constitute a major industry, employing a substantial proportion of the inmates. Contract labor is undoubtedly responsible for introducing and maintaining shirt-making on a large scale as a prison industry; with the certain decrease (possibly the elimination) of contracts in I934, garment-making will probably decrease sharply and where it remains will become more diversified. State-use clothing shops now make a variety of garments, not work shirts, overalls or pants alone. Similarly, quantity production of shoes was begun in prisons by contractors, but now has a place wherever state-use needs are filled. The same seems to be true of furniture also, and here again state-use needs operate to force diversification, so that whereas a contract furniture shop will make only chairs in one or two styles, a state shop must make chairs, tables, bureaus, chiffoniers, cabinets, desks, racks, and so on.

Just about half the states now make their own automobile license tags in prisons, ${ }^{1}$ and often the manufacture of highway markers and other tags is added, but such shops employ relatively few men. Foundry work, stone products,

${ }^{1}$ Prison Industries, p. 107; American Year Book (1929), p. 493. 
brushes, and brooms are next in order of frequency. Nine middle western states (Minnesota, North Dakota, South Dakota, Kansas, Missouri, Indiana, Michigan, Oklahoma, Wisconsin) were manufacturing binder twine in 1929.

Kansas and Tennessee produce coal and Tennessee also burns coke. Minnesota regularly manufactures farm machinery and Oregon made some flax-pulling machines in $1927-28 ;^{1}$ Oregon is likewise the only state whose prison is in the flax industry. Only San Quentin Prison makes jute bags; only the Penitentiary at Nashville, Tennessee, now makes stoves, although this used to be a more popular trade for prisons ${ }^{2}$ and the competition was still a matter of bitter complaint in 1923. ${ }^{3}$ Iron hollow ware is made in two or three institutions, Nashville among them. The State Prison at Thomaston, Maine, makes wagons and sleighs, and the Maryland House of Correction makes wire goods. The two dye shops of which we know are at Auburn, New York, and Jackson, Michigan; coffee roasting is confined to the New Jersey State Prison at Trenton. Rope making has been added to the list of Minnesota prison products. The rest of the industries listed are found here and there the country over.

1 Oregon State Penitentiary, 14 th Biennial Report (1927-28), p. II.

2 Commissioner of Labor, 2nd Annual Report, 1886, pp. 64, 66, 68, 93; 20th Annual Report, 1905, p. 311.

Conoict Labor in 1923, pp. $143^{-8 .}$ 


\section{Building Construction by Prison Labor}

A question related to the matter of industries is the practicability of using prison labor on construction work. The experience of many prisons proves that this is entirely feasible, and that good results can be achieved at costs well below those of free-labor construction, although inmate labor is slower. Thirty-five institutions out of the ninety-eight listed in the 1929 Handbook were using inmates on construction projects. Outstanding among prisons now being built partly by inmate labor are the new Eastern Penitentiary at Graterford, the new Illinois Penitentiary at Stateville outside of Joliet, the new Michigan prison at Jackson, and the Norfolk Prison Colony in Massachusetts. Graterford, Stateville, and Jackson are all enormous projects calling for high concrete walls, great cell blocks, power plants, hospitals, administration and shop buildings. Prison labor is proving as successful at building these complicated plants as at erecting simpler structures like the dormitories of the Norfolk Colony, the London (Ohio) Prison Farm or the Berks County Prison at Reading, Pennsylvania. The Indiana Reformatory at Pendleton built a $\$ 75,000$ chapel in 1928 and "inmate labor was used in every phase of the construction."1 Another institu-

1 "New Construction at Some of the State Institutions," Indiana Bulletin of Charities and Correction, No. I 71-2 (June-July I929), 333. 


\section{SHOULD PRISONERS WORK?}

tion which has had successful experience with convict construction is the Kansas State Penitentiary; in its Report for 1927-28, the warden tells of rebuilding an old cell house:

The brick was made at the prison, the rough lumber cut and sawed from the timber obtained in clearing the Stiger Island farm, and the stone for concrete was furnished by our shale-pit quarry crusher. All the labor required, as stated, skilled and unskilled, was done by prisoners, and the building is a credit to them and to the state of Kansas. It was finished well within the appropriation granted ...

... I might add that the funds made available ror the work of rebuilding the cell house were taken from the revolving fund of the twine department; in other words, from the profits which had accrued from the operation of the twine mill. 1

The same prison built a new laundry too, using stone from the dismantled cell block and building the new structure around and over the old one without stopping the laundry work. ${ }^{2}$ The use of the old materials precluded the necessity for an appropriation. Penitentiary men also constructed an administration building and a dormitory for the Kansas Women's Industrial Farm. ${ }^{3}$

Opposition to Specific Trades or Industries

The matter of competition with free labor has already been discussed in Chapter III, but it is pertinent here to point out that opposition

\footnotetext{
1 Twenty-sixth Biennial Report, p. 7.

${ }^{2}$ Ibid., p. 8; I929 Handbook, p. 363 .

${ }^{3}$ Kansas State Penitentiary, 26th Biennial Report, pp. 8-9.
} 
has invariably come from trades which are heavily represented on our list of prison industries. At hearings before the House Committee on Labor in 1926, on the pros and cons of a bill almost identical with the Hawes-Cooper Bill, the witnesses supporting the proposed legislation represented the garment, cotton textile, broom, furniture, and cordage industries. $^{1}$ The interests of the shoe manufacturers were also defended. ${ }^{2}$ The record of the hearings on the Hawes-Cooper Bill itself, before the Interstate Commerce Committee in 1928, are full of similar protests, including a letter from the Building Trades Council of St. Louis. ${ }^{3}$ Since construction work differs from factory production in its competitive effect, that letter apparently was written to give support to the efforts of affiliated labor organizations interested in keeping prison goods off the market. It may, however, have been aimed against the brick plant formerly operated at the Missouri Penitentiary. The prison brickyard at Jackson, Michigan, was forced to close on account of outside opposition. ${ }^{4}$

The only prominent prison industries which have not been specifically protested at these

1 Convict Labor: Hearings Before the Committee on Labor ... on H.R. 8653 (Washington, I926).

${ }^{2}$ Ibid., p. 27.

${ }^{3}$ Convict Labor: Hearings on S. 1940 (Washington, 1928), p. 78.

4 American Year Book (1926), p. 626. 


\section{SHOULD PRISONERS WORK?}

hearings - aside from the American Federation of Labor's general opposition to all forms of prison production for the open market - are printing, farming, stone, and sheet metal. Most effective opposition to printing as a prison industry, however, is evident in the New York law forbidding any state work except that of the Department of Correction to be done in prison. And occasional protests are now heard from the farmers. ${ }^{1}$ Although license tags are perhaps the most conspicuous single item in the list of sheet metal products, yet they are also a very obvious industry for the state-use system advocated by trade representatives; those same representatives have not, therefore, had the face to protest against the industry at Congressional hearings, but the Idaho State Federation of Labor protested the purchase of Idaho's license tags from the Washington State Penitentiary, and the sheet metal workers of Illinois were reported as going on record against the manufacture of license plates at the State Prison. ${ }^{2}$

\section{Jobs Prisoners Might Do}

(State and Federal Institutions)

The list which has been compiled includes most industries suitable for prison production; there are not many more which could be added.

${ }^{1}$ Cf. p. 78 above.

2 Hearings on S. 1940, pp. I 53, 173. 
Major industrial products most conspicuous by their absence are the basic metals (iron, steel, copper, lead, brass, and alloys), glass, silk goods, tools and cutlery, structural iron and steel work, rubber products, paper and wood pulp, chemicals (excepting soap, dyes, and paints), gas and petroleum products, electrical machinery, stationary engines, and motor transportation equipment of all kinds. Most of these are unsuitable for prison use, ruled out by the location of raw materials, or by the requirements of mass production, by engineering needs, and the necessity for highly trained labor. Silk products are in the luxury class as compared with cottons and woolens, and have no place in the institutional requirements which are coming more and more to be a primary guide to practical prison manufacturing. The manufacture of goods from raw rubber is out of the question because of engineering requirements, but tire repairs and vulcanizing should be entirely feasible in any prison.

Prison labor is not adaptable to industries requiring very fine materials and great technical skill. Nor can it hope to compete where style requirements play too large a part in market demands and designs are subject to radical fluctuations. One solution of prison labor difficulties lies not so much in finding new industrial lines which are adaptable to prison requirements as in developing to the full the variant possi- 


\section{SHOULD PRISONERS WORK?}

bilities of types of industry already established in the prison field, and at the same time using maintenance and construction opportunities to the limit. (Thus the motor cars and trucks used by an institution might well be made to serve as the nucleus of an automobile repair shop and the foundation of a training course for mechanics. ${ }^{1}$ ) We may, however, note a few suggestions for industries not now in operation in any of our prisons, so far as we know.

The Kentucky State Board of Charities and Corrections in 1929 recommended the establishment of a factory for the manufacture of tin cans; such a project would be especially desirable in those prisons now operating canneries. ${ }^{2}$

Reforestation work has also been advocated as a means of employment of prisoners. ${ }^{3}$ The Rockview Branch of the Western State Penitentiary (Pennsylvania) has a tree nursery from which it ships seedlings, transplants, and stock to forestry departments in its own state and others $;^{4}$ an extension of this undertaking to include the actual planting out of trees in areas needing reforestation might be feasible under some circumstances; there seems to be no good reason why small reforestation camps could not be run as easily as road camps.

1 MacCormick, Education of Adult Prisoners, pp. I25-6.

2 Report (1928-29), p. 35 .

New York Prison Survey Committee, op. cit., p. 96.

- Secretary of Welfare, 4th Biennial Report (1927-28), p. 88. 
It might also be possible to use prisoners to maintain fish hatcheries and restock the waters of a state, as was suggested in 1923 for Colorado. ${ }^{1}$

Wood pulp used to be produced by prisoners working in a private mill near the Maine State Reformatory for men. ${ }^{2}$

Another suggestion is that prisoners be used in reclaiming waste materials. ${ }^{3}$ The naval prison at Portsmouth, New Hampshire, does "considerable salvaging of clothes and shoes," 4 and it seems offhand as if this were an occupation which might prove practical for Federal civil prisons. Other new activities recommended for the Federal penitentiaries by the Bureau of Efficiency in 1926 included the making of automobile spare parts and other machineshop products such as scales for post offices, a paper mill, a shop for making stationery and office supplies, and the expansion of leather goods industries to produce not only shoes but gloves and bags, etc. ${ }^{5}$

The Bureau of Efficiency's report on the subject of possible industries displays a degree

\footnotetext{
${ }^{1}$ L. D. Clark, "Labor Laws and Court Decisions; Convict Labor," Monthly Labor Review, XVIII (I924), 655.

2 Convict Labor in 1923, p. 38; letter from A. H. MacCormick, July 10, I931.

"Hugh Frayne, "The States Use System," Fournal of Criminal Law and Criminology, XII (Nov. I921), 334 .

4 I929 Handbook, p. IOI.

$5 \mathrm{~J}$. V. Bennett and A. G. Thomas, "Interim Report on Analysis of Government Purchases for Prison Industries Program," Federal Penal and Reformatory Institutions, Appendix II.
} 


\section{SHOULD PRISONERS WORK?}

of thoroughness, common sense, and openmindedness all too unusual in this controversial field, and the investigators approached the problem in a scientific manner. Their study is highly interesting and instructive, although it is a preliminary report and only considers in detail the first two of the aspects outlined below:

The Bureau of Efficiency was requested by the Department of Justice to make an analysis of the supplies and materials purchased by the Federal Government for the purpose of assisting it in determining which of them might be produced advantageously in the Federal penal and correctional institutions by utilizing the labor of those inmates who are now idle. A preliminary analysis of the various items has been completed. The results indicate that the Federal authorities are in a much more favorable position than are State penal officials so far as concerns the usually perplexing problem of how to dispose of the product of convict labor. The broad field offered by the Federal Government makes it possible to choose, to a considerable extent and without abandoning the "Stateuse" system, among a diversity of industries. In fact it appears to be of primary importance to narrow the field and concentrate upon those industries which seem to offer the greatest possibilities.

The problem of determining what products could be made to advantage in the Federal prisons and sold to the various departments and Government establishments has been approached in the belief that certain fundamental conditions must be met before any industry can be given even preliminary consideration. First of all, it has been considered essential that the industries be diverse in number and character. Secondly, the products must be of a standard type, in continual demand, and used in 
sufficient quantities, so that efficient production is possible without monopolizing, for any one class of products, the entire Government market. In the third place, the industry must have some vocational or rehabilitation value without being so highly skilled as to prevent the average prisoner from becoming, after a reasonable training period, an effective producer. Finally, the industries must be practical of installation from the standpoint of cost of equipment and buildings, availability of raw materials, and transportation of the finished product. ${ }^{1}$

The Bureau of Efficiency's report is almost the only accurate study which has been made to determine exactly what industries can feasibly be established in a given group of prisons. Its conclusions do not add greatly to the major headings on our list of prison industries which have "just growed," but it indicates how the activities of shops already established may be enormously expanded in accordance with the needs of the given market. Thus many states have prison tag shops, but few such shops manufacture more than one or two of the other sheet metal or tin articles which Bennett and Thomas list as used in quantity by the Federal Government: filing cabinets, transfer and stamp cases, book cases, lockers, garbage and ash cans, paint cans, miscellaneous cans, galvanized iron buckets, bag racks, etc., galvanized iron tubs, household utensils, paper cutters, paper clips and fasteners, cuspidors, metal stamps, drums, tanks and barrels, wheelbarrows, metal signs,

i Ibid., p. 207. 


\section{SHOULD PRISONERS WORK?}

steel shelving. ${ }^{1}$ (Items for which state governments would have no use, such as letter carriers' badges, have been omitted.) We do not say that every state prison tag shop should manufacture all the various articles recited; we merely wish to give a concrete example of the expansion which careful surveys of markets and resources will show to be possible for many existing prison industries. It is not possible except in a general way to say what industries prisons will or will not find adaptable. Each institution or group of institutions must settle its own specific problem by an analysis of, first, its population and, second, its market, whether unrestricted or confined to the state's needs. Diversification will be found essential, even where goods are sold on the open market, since it greatly reduces the chances of hostile attacks by manufacturers and labor men and greatly increases opportunities for reëducating prisoners.

I Ibid., p. 213. 


\section{VIII \\ CONCLUSIONS}

One fact stands out above all others revealed by this brief study of a complicated problem, and that is the glaring discrepancy existing between the accepted theory that prisoners should work and the all too extensive practice of keeping them in idleness. Yet no one will or can deny the soundness of the principle that work is the basis upon which prison life must develop; never can a prison which keeps its inmates in idleness serve society in any but a pitiful and inadequate way. Even though it may be extremely difficult to put prison industries on a paying basis financially, they should always be set up as a part of a sane penological program. This fact has not been burnt into the consciousness of the country, and the apathetic public attitude prevailing towards prison idleness is a sad commentary on our state of cultural development. To make bricks without straw is easy compared with the task of making decent citizens out of criminals without work.

It is well worth remembering that the man in the street, while believing theoretically and 


\section{SHOULD PRISONERS WORK?}

firmly that prisoners should work, is actually opposed to their employment if they produce goods which compete with those he makes. In legislative halls he is certain to be much more voluble as a producer than as an advocate of penal reform. It is of course only too true that the competitive aspect of prison industries has been very badly handled. There has been a heavy concentration of production on certain lines of goods. This and the knowledge that certain private concerns were reaping a profit from the employment of wards of the state have combined to win both the selfish and the unselfish interests to the support of a program of restriction, aiming to prohibit the sale of prison goods on the open market.

But the difficulties connected with the stateuse system, devised to reconcile the prisoner's need for work with the free producer's objection to prison competition, have not been appreciated or well understood. It is very unlikely that states with small populations and meager resources can ever keep their prisoners employed if restrictions limit the market to public institutions and agencies, while even large and wealthy states will probably be unable to employ the state-use system exclusively. Some leeway to sell on the general market and to the agencies of other states is necessary, and does not constitute unfair competition. Furthermore, the 
state is by no means so able a business man as the private person, and it is idle to assume that the state-use system gives prison goods a specified market which will not need to be constantly defended. The opposition of free labor and manufacturing interests does not automatically disappear with the adoption of the system they favor; their coöperation, so essential if any scheme of prison production for state-use consumption is to be successful, must constantly be enlisted and reënlisted. Prison authorities must wage an endless campaign to keep labor and trade groups interested in the prisoner's rehabilitation, and to interpret prison labor policies intelligently in the public press; otherwise, even under the state-use system, individual projects for the employment of prisoners will meet with hostility from local chambers of commerce and labor organizations.

Such opposition is determined and instinctive; it is a natural reaction to the prospect of losing markets and jobs. Any producer will blindly and doggedly try to eliminate competition which intensifies his own struggle for a living, unless the idea of social responsibility is forced in to his head again and again and again.

A prison industry must voluntarily restrict within reasonable bounds the competition it offers free industry, or it stands a good chance of being more drastically restricted by law, B.P.w. -20 


\section{SHOULD PRISONERS WORK?}

even eliminated. Prison officials in Massachusetts are well aware of the trouble to be encountered by pursuing a policy which disregards trade opposition, and from the beginning of the state-use system there they have sought coöperation. Superintendent Gill, of the Norfolk Prison Colony, told the New York Crime Commission of the policy he pursued when the work of constructing the institution was begun. At the outset, when only the wall was started, the unions did not bother to object.

"However," says Mr. Gill, "the first thing I did, on taking charge of the construction of the wail, was to call in the local head of the Building Trades Council, and I said to him 'Now, we want to work in harmony with you if you will work with us.' In fact, he was told to come on the job at any time, inspect the work, and tell us what he thought about it. We hired union carpenters and paid them union wages; we hired union cement finishers and we paid them union wages, and they worked under union conditions, and had union hours. But when the question of building the institution came up, a little group came to see me ... We had a consultation with the officers of the State Building Trades Council, and of the Carpenters', Electricians', Painters', Plumbers', Steamfitters', Iron Workers', Bricklayers', and Masons' unions. Their first proposition was, of course, that no inmate could work on those buildings with tools.

They would oppose any plan to operate if inmates were to use tools. They did not object to their being laborers or hod carriers, but they felt that the technical jobs should be exclusively the prerogative of union labor. We threshed that question out in three or four very long, very interesting conferences, and I may say that ... they showed a very fair, open-minded and socially-minded 
point of view in the matter. We finally agreed on this basis: The state would not restrict itself as to the use of inmates. The unions recognized that these men had to be trained, and if they had aptitude to be skilled workmen, they ought to have tools to work with.

We agreed to hire union help, to pay union wages, and to conduct our work under union conditions, and in principle we recognized the apprenticeship regulations of the unions, to this extent: That the unions would set up the regular regulations with reference to apprentices, and that we would then be limited in our choice of prisoners who could be certified for apprentices, to that number -I don't just recall the number, but we will say it is one apprentice to six civilian carpenters. Sometimes it is one apprentice to one journeyman, .... sometimes one to six, sometimes one to three - but we would not be restricted [as] to the number of men who might be candidates for that apprenticeship. For example, if we have six civilian carpenters and six inmate helpers with tools working with those carpenters, we might have Io or I5 other candidates for that job doing some of the rough carpentry work with simple tools. In other words, we might have a gang of about 18 inmates with tools working with six civilian carpenters, although we agree that only one of those inmate carpenters can be certified as an apprentice if he makes the grade. Thus we recognize the principle of apprenticeship without restricting in any way the use of the inmates on technical work with tools.

In return, the unions agreed that they would help us set up a course of instruction for these men, such as they felt was essential if the men wanted to become union workmen, that they would give credit to those men who completed that course and became certified as apprentices, and ... that they would grant any such man a certificate of good work to take to his home town as a letter of introduction to his union. ${ }^{1}$

${ }^{1}$ MS stenographic report of proceedings, November 21, 1929, pp. I409-II; as corrected in letter of August 7, 1931. 


\section{SHOULD PRISONERS WORK?}

This description of the technique necessary in dealing with free labor points unmistakably to the fact that the state-use system makes strenuous demands upon those who administer it, proving (we think) our contention that this method of employing prisoners does not create a separate world of production and sale within which public officials may do what they please, untroubled by any conflicts with the free world of economic enterprise. It seems certain, however, to become the most generally accepted type of prison employment, and the final point which we wish to make is that to run it successfully requires talent of a higher order on the part of prison officials than does the operation of any one of the other systems. Better personnel in turn requires larger salary budgets.

Some may object to our emphasis on the financial aspects of prison labor, insisting that it is a minor phase of penal administration. To this we cannot agree. Professor Harry Elmer Barnes said ten years ago that economics and penology could not be divorced without disastrous consequences, ${ }^{1}$ and the facts detailed in the present study bear out that opinion if they do nothing else. There is more reason to develop a sound system of accounting for prison industries than for those

"Economics of American Penology as Illustrated by the Experience of the State of Pennsylvania," Fournal of Political Economy, XXIX (I92I), 64I. 
conducted by free men. Prison industries are hampered by so many laws and peculiar circumstances that we should always be able to ascertain the exact financial status in order to plan the next steps of our penological program. If the financial returns are such that we can never hope to pay prisoners decent wages, then we ought to know it. If the state tends, as we believe it does, to load on to the industries penological costs which it, itself, should bear as a penalty for its responsibility for crime, then we should change this policy. If, on the other hand, the effect of legal restrictions and of incompetent management is covered up through a neglect to charge the industry with costs which belong to it, then such facts should be brought to the attention of those ultimately responsible for the situation. Without sound accounting, no intelligent criticisms or suggestions can be made. Taxes cannot be depended on to furnish more than a part of the money that will be necessary for the development of a worthwhile penological system: the prisoners will be called upon to do their share, but they cannot help without the opportunity to work and to earn. The public should see that unless the prison industries are reasonably successful financially no wages worthy the name will be paid, and that without wages the penologist's whole program of having the offender compen- 


\section{SHOULD PRISONERS WORK?}

sate his victim, support his dependents, and pay something to society for the trouble caused by his crime falls to the ground. Furthermore without wages, and good wages at that, our chance of reedducating the prisoner along economic lines is gone. Perhaps we must accept the idea that the prisoner is a bankrupt who owes more than he can ever pay. But even so, it is customary to ask a bankrupt to pay what he can on his debts, and at least he should know and we should know why he cannot pay more, in order to settle on some definite, understood basis.

Of course nothing in the preceding paragraphs should be interpreted as favoring the return of the leasing which was responsible for so much misery or the contracts which turned many prisons into sweat shops of the worst kind. Proper attention to financial matters most emphatically does not mean exploitation of the prisoner. We are not proposing to make money instead of trying to re-make the offender, or to parallel the Industrial Revolution and impose upon prison workers conditions which free workers have fought for over a century. In the free world today it is taken for granted that reputable firms do not exploit their workers, and, similarly, we expect well-organized prison shops to be conducted under proper working conditions. Theoretically, prison industries should also pay 
wages commensurate with wages on the outside. If it proves impossible to pay any wage worth the name, can we achieve the desired reëducation of the worker by some other means?

Some keen students of prison matters believe that the deduction of time from sentence"good time," or "time-off" - can be substituted for a money wage or at least used in conjunction with money, as an incentive to good work. This predicates, of course, the indeterminate sentence with a stated minimum and maximum, and, in the hands of a good administrator, would certainly serve as an effective disciplinary device. But we are interested less in maintaining discipline within the walls than in fitting a man to be a social asset when he gets out, and therefore the use of time-off as a substitute for money wages seems to have disadvantages. Time-off does not teach the prisoner how to function as part of a profit-making organization - which is what he must do, to keep his head above water in our present industrial system - nor does it appear as a labor charge on the accounts of the prison industry; which, as has been emphasized repeatedly in these pages, must reckon with labor charges if it is to be conducted in a normal manner and play an effective part in the prison program. But the idea of using time-off as a wage, not a reward for good behavior, is worth study none 


\section{SHOULD PRISONERS WORK?}

the less, and especially in its relation to the financial background of the prison industry. After all, the financial aspects of prison labor ought to be vitally important even to reformers who are interested solely in the rehabilitation of prisoners.

After reviewing the available material on the subject, we are inclined to believe that some reformers are too optimistic not only in the matter of wages, but also about the possibility of teaching all prisoners a trade which they can practice on release.

... the teaching of trades ... has its drawbacks, as is shown by the experience of some of our state reformatories. Former inmates do not pursue the trades they have been taught in the institution, either because they do not desire to do so, or because they cannot fit in with the trades in the outside world. Then, again, it is folly to proceed on the theory that all those who go to our State prisons or reformatories are capable of learning a trade ....1

Quite a large percentage of the human material in prisons, especially in jails, is not the stuff out of which expert mechanics are made. Some - far more than are now being taught can learn trades, but, for many, the most that we can hope is that institutional life will tend to develop habits of industry and effect changes in attitude which will make it easier to hold a job. Manual and factory work of one sort or

${ }^{1}$ E. R. Cass, "Prison Labor," Prison Association of New York, 83rd Annual Report (1927), p. 86. 
another, little related to a skilled trade, will continue to be the work fate of the majority of prisoners. . But we should remember that such is also the situation on the outside, and that true vocational education means teaching men to be effective and worth hiring, no matter what their jobs. If they are to learn factory work, then they must learn to maintain a normal rate of production.

One of the most significant lessons which this brief survey of the prison labor problem has to teach is that as a rule it will be easier to find paying work outside the prison than in it, that the possibility of an offender's supporting his dependents is far greater when he is working as a free man than when he is working as a convict, and that all the benefits to prisoners and society alike which we anticipate from a good prison labor program could be more easily obtained if offenders were properly treated on probation. Prisons are at best unnatural places. It is idle to believe that we can build within them an industrial system as good as the one on the outside, but this must not be considered an excuse for maintaining delinquents in idleness, because so long as prisons are still necessary we are under direct moral obligation to make them institutions for the betterment of humanity.

No social group can fairly evade its share of responsibility for the proper conduct of penal 


\section{SHOULD PRISONERS WORK?}

and correctional institutions, but since it is not possible to reconcile conflicting interests completely, some sacrifice there will have to be if prisoners are to have employment. The burden need not be excessively heavy upon any one group: each trade will have to bear its share of shrinkage in possible sales, of curtailment of possible profits, and of lessened employment for free labor; local farmers will be faced with the loss of institutional markets; while the tax-paying public will have to realize that a penny-wise-and-pound-foolish policy in the administration of prison industries tends to increase, not decrease, the cost of crime.

There seems to be one practical method of achieving the desired coöperation between groups whose interests are at variance. That is to assign to each some definite share of the responsibility for conducting prison industries. In New Jersey organized labor is represented on the State Board of Control, and on the managing boards of the New Jersey State Prison and the Rahway reformatory, with the result that, in operating prison industries on a training basis, the state authorities have enjoyed very effective coöperation from labor men. ${ }^{1}$ The industries of two important French prisons (Fresnes and Poissy) are reported to be administered by a commission made up "of a representative of

\footnotetext{
${ }^{1}$ Letter from Commissioner William J. Ellis, April 30, I93I.
} 
the Government, a representative of the $\mathrm{Na}$ tional Chamber of Commerce, and a representative of organized labor." 1 So effective is this method of control that Dr. Hastings H. Hart found most of the prisoners employed when he visited Fresnes and Poissy in $1925{ }^{2}$ in spite of the fact that the franc was worth only five cents and "hundreds of thousands of people" were out of work. ${ }^{3}$ Such a condition is a tribute not only to good prison management but to the good sense of the French public. The author knows from first-hand observation that people in England, Belgium, Holland, and Germany are equally conscious of the fact that prisoners must have work, and so support a policy which tolerates no idleness in prisons, even at times of industrial depression.

It is not fair to trace all the unsatisfactory labor conditions in the prisons of the United States to the one difficulty of avoiding competition with free labor and free manufacturers. The enormous amount of idleness in county jails, for example, is due to several factors: they usually serve too small units of government, they were not built with the thought of furnishing employment to their inmates, and they are located in towns instead of in the

\footnotetext{
${ }^{1}$ Prison Industries, p. $8 \mathrm{I}$; statement credited to Dr. Hastings $\mathrm{H}$. Hart, of the Russell Sage Foundation.

2 Testimony before New York State Crime Commission, MS stenographic report of proceedings, November 22, I929, p. I478.

${ }^{3}$ Prison Industries, $\mathrm{p}, 8 \mathrm{I}$.
} 


\section{SHOULD PRISONERS WORK?}

country. The effects of poor management in penal institutions large and small have been detailed at some length. But the most potent underlying cause of unemployment in prisons of every kind is the absence of any settled public opinion in favor of adequate work - any definite popular support such as sane prison labor policies enjoy in Europe. We should face the fact that our correctional organization has suffered greatly from neglect, in spite of the spasmodic building of huge prisons. Without the creation of an intelligent public opinion, disinterested and ever watchful, there can be no intelligent penal program in a democracy such as ours. In the last analysis the American citizen-at-large, the man in the street whose opinions were the starting point of this study, is the person responsible for the lack of work which he deprecates. 


\section{APPENDIX I}

Extent of Employment and Unemployment in State and Federal Penal and Correctional Institutions, 1927-28*

A. Eastern States

\begin{tabular}{|c|c|c|c|c|c|c|}
\hline & $\begin{array}{l}\text { Total } \\
\text { PENAl } \\
\text { Popu- } \\
\text { LAtion }\end{array}$ & $\begin{array}{l}\text { Produc- } \\
\text { TIVELY } \\
\text { EM- } \\
\text { PLOYED }\end{array}$ & $\begin{array}{c}\text { EM- } \\
\text { PLOYED } \\
\text { ON } \\
\text { MAINTE- } \\
\text { NANCE }\end{array}$ & $\begin{array}{l}\text { Not } \\
\text { Work- } \\
\text { ING }\end{array}$ & $\begin{array}{l}\text { DEFI- } \\
\text { NITELY } \\
\text { IDLE }\end{array}$ & $\begin{array}{l}\text { Not } \\
\text { Accounted } \\
\text { FOR }\end{array}$ \\
\hline Connecticut... & 943 & $\begin{array}{r}747 \\
79 \% \\
\end{array}$ & $\begin{array}{r}182 \\
19 \% \\
\end{array}$ & $\begin{array}{r}14 \\
2 \% \\
\end{array}$ & $\cdots$ & $\cdots$ \\
\hline Maine........ & $36_{3}$ & $\begin{array}{r}126 \\
35 \% \\
\end{array}$ & $\begin{array}{r}143 \\
39 \% \\
\end{array}$ & $\begin{array}{r}24 \\
7 \% \\
\end{array}$ & $\begin{array}{r}15 \\
4 \% \\
\end{array}$ & $\begin{array}{r}70 \dagger \\
19 \% \\
\end{array}$ \\
\hline Massachusetts & I,944 & $\begin{array}{r}1,225 \\
63 \% \\
\end{array}$ & $\begin{array}{r}637 \\
33 \% \\
\end{array}$ & $\begin{array}{r}82 \\
4 \% \\
\end{array}$ & $\cdots$ & $\cdots$ \\
\hline $\begin{array}{l}\text { New } \\
\text { Hampshire }\end{array}$ & II9 & $\begin{array}{r}85 \\
72 \% \\
\end{array}$ & $20 \%$ & $\begin{array}{r}10 \\
8 \%\end{array}$ & $\cdots$ & $\cdots$ \\
\hline New Jersey... & 2,550 & $\begin{array}{r}1,138 \\
45 \% \\
\end{array}$ & $\begin{array}{r}587 \\
23 \% \\
\end{array}$ & $\begin{array}{r}825 \\
32 \% \\
\end{array}$ & $\begin{array}{r}326 \\
13 \% \\
\end{array}$ & $\cdots$ \\
\hline New York.... & 8,101 & $\begin{array}{r}3,273 \\
41 \% \\
\end{array}$ & $\begin{array}{r}3,329 \\
41 \% \\
\end{array}$ & $\begin{array}{r}833 \\
10 \% \\
\end{array}$ & $\begin{array}{r}\text { ?t } \\
\cdots \cdots \\
\end{array}$ & $\begin{array}{l}666 \dagger \\
8 \%\end{array}$ \\
\hline Pennsylvania & 4,584 & $\begin{array}{r}1,630 \\
36 \% \\
\end{array}$ & $\begin{array}{r}1,522 \\
33 \% \\
\end{array}$ & $\begin{array}{r}647 \\
14 \% \\
\end{array}$ & $\begin{array}{l}342 \\
7 \% \\
\end{array}$ & $\begin{array}{r}785 \dagger \\
17 \% \\
\end{array}$ \\
\hline Rhode Island & 636 & $\begin{array}{r}459 \\
72 \% \\
\end{array}$ & $\begin{array}{r}128 \\
20 \% \\
\end{array}$ & $\begin{array}{r}49 \\
8 \% \\
\end{array}$ & $\cdots$ & $\cdots$ \\
\hline Vermont...... & $33^{2}$ & $\begin{array}{r}213 \\
64 \% \\
\end{array}$ & $\begin{array}{r}108 \\
33 \% \\
\end{array}$ & $\begin{array}{r}11 \\
3 \% \\
\end{array}$ & $\begin{array}{r}10 \\
3 \% \\
\end{array}$ & $\cdots$ \\
\hline 9 States. . & 19,572 & $\begin{array}{l}8,896 \\
45 \% \\
\end{array}$ & $\begin{array}{l}6,660 \\
34 \% \\
\end{array}$ & $\begin{array}{r}2,495 \\
13 \% \\
\end{array}$ & $\begin{array}{l}693 \\
4 \% \\
\end{array}$ & $\begin{array}{c}\text { I, } 521 \dagger \\
8 \%\end{array}$ \\
\hline
\end{tabular}

* Prisons and adult reformatories, including women's institutions

† Majority employed, but exact number unknown

Indicates that some of those not working are idle, but exact number unknown 


\section{APPENDIX}

\section{B. Southern States}

\begin{tabular}{|c|c|c|c|c|c|c|}
\hline & $\begin{array}{l}\text { Total } \\
\text { PENal } \\
\text { Popu- } \\
\text { LATION }\end{array}$ & $\begin{array}{c}\text { PRODUC- } \\
\text { TIVELY } \\
\text { EM- } \\
\text { PLOYED }\end{array}$ & \begin{tabular}{|c|} 
EM- \\
PLOYED \\
ON \\
MAINTE- \\
NANCE \\
\end{tabular} & $\begin{array}{c}\text { Not } \\
\text { WorR- } \\
\text { ING }\end{array}$ & $\begin{array}{c}\text { Defi- } \\
\text { NITELY } \\
\text { IDLE }\end{array}$ & $\begin{array}{l}\text { Not } \\
\text { Accounted } \\
\text { FOR }\end{array}$ \\
\hline Alabama...... & 3,674 & $\begin{array}{r}3,188 \\
87 \%\end{array}$ & $\begin{array}{l}288 \\
8 \%\end{array}$ & $\begin{array}{l}198 \\
5 \%\end{array}$ & $\begin{array}{l}39 \text { at } \\
\text { least } \\
\text { 1\% }\end{array}$ & $\cdots$ \\
\hline Arkansas..... & c. 1,456 & $\begin{array}{r}1,356 \\
93 \% \\
\end{array}$ & $\begin{array}{l}100 \\
7 \% \\
\end{array}$ & $\cdots$ & $\cdots$ & $\cdots$ \\
\hline Delaware..... & 1,018 & $\begin{array}{r}332 \\
32 \% \\
\end{array}$ & $\begin{array}{r}132 \\
13 \% \\
\end{array}$ & $\begin{array}{r}554 \\
54 \% \\
\end{array}$ & $\begin{array}{r}8 \\
1 \% \\
\end{array}$ & $\cdots$ \\
\hline Florida........ & 2,564 & $\begin{array}{r}1,645 \\
64 \% \\
\end{array}$ & $\begin{array}{r}919 \\
36 \% \\
\end{array}$ & $\cdots$ & $\cdots$ & $\cdots$ \\
\hline Georgia.. & 3,272 & $\begin{array}{r}2,940 \\
90 \%\end{array}$ & $\begin{array}{r}70 \\
2 \%\end{array}$ & $\begin{array}{c}\text { c. } 50 \text { at } \\
\text { least. } \\
2 \%\end{array}$ & $\cdots$ & $\begin{array}{l}212 \\
7 \%\end{array}$ \\
\hline Kentucky..... & 2,395 & $\begin{array}{r}1,765 \\
74 \% \\
\end{array}$ & $\begin{array}{r}498 \\
21 \% \\
\end{array}$ & $\begin{array}{l}132 \\
5 \% \\
\end{array}$ & $\begin{array}{r}\text { c. } 90 \\
4 \% \\
\end{array}$ & $\cdots$ \\
\hline Louisiana. . & 1,687 & $\begin{array}{r}1,380 \\
82 \% \\
\end{array}$ & $\begin{array}{r}307 \\
18 \% \\
\end{array}$ & $\cdots$ & $\cdots$ & $\cdots$ \\
\hline Maryland..... & 2,132 & $\begin{array}{r}1,360 \\
64 \% \\
\end{array}$ & $\begin{array}{r}244 \\
\text { I I \% } \\
\end{array}$ & $\begin{array}{r}528 \\
25 \% \\
\end{array}$ & $\cdots$ & $\cdots$ \\
\hline Mississippi.... & c. 1,666 & $\begin{array}{r}1,621 \\
97 \% \\
\end{array}$ & $\begin{array}{r}\text { c. } 45 \\
3 \% \\
\end{array}$ & $\cdots$ & $\cdots$ & $\cdots$ \\
\hline North Carolina & $\mathrm{I}, 774$ & $\begin{array}{r}1,646 \\
93 \% \\
\end{array}$ & $\begin{array}{l}107 \\
6 \% \\
\end{array}$ & $\begin{array}{r}21 \\
1 \% \\
\end{array}$ & $?$ & $\cdots$ \\
\hline Oklahoma.... & 3,303 & $\begin{array}{r}1,878 \\
57 \% \\
\end{array}$ & $\begin{array}{r}1,192 \\
36 \% \\
\end{array}$ & $\begin{array}{l}233 \\
7 \% \\
\end{array}$ & $\begin{array}{r}19 \\
1 \% \\
\end{array}$ & $\cdots$ \\
\hline South Carolina & 456 & $\begin{array}{r}331 \\
72 \% \\
\end{array}$ & $\begin{array}{r}95 \\
21 \% \\
\end{array}$ & $\begin{array}{r}30 \\
7 \% \\
\end{array}$ & $\cdots$ & $\cdots$ \\
\hline Tennessee. & 2,219 & $\begin{array}{r}1,695 \\
76 \%\end{array}$ & $\begin{array}{r}321 \\
15 \% \\
\end{array}$ & $\begin{array}{l}203 \\
9 \% \\
\end{array}$ & $\cdots$ & $\cdots$ \\
\hline Texas... & c. 4,260 & $\begin{array}{r}.3,717 \\
87 \% \\
\end{array}$ & $\begin{array}{l}384 \\
9 \% \\
\end{array}$ & $\begin{array}{l}159 \\
4 \% \\
\end{array}$ & $\begin{array}{l}110 \\
3 \% \\
\end{array}$ & $\cdots$ \\
\hline Virginia.. & c. 3,364 & $\begin{array}{r}2,867 \\
85 \% \\
\end{array}$ & $\begin{array}{r}426 \\
13 \% \\
\end{array}$ & $\begin{array}{r}71 \\
2 \% \\
\end{array}$ & $\cdots$ & $\cdots$ \\
\hline West Virginia & 1,892 & $\begin{array}{r}1,312 \\
69 \%\end{array}$ & $\begin{array}{r}287 \\
15 \% \\
\end{array}$ & $\begin{array}{r}293 \\
16 \% \\
\end{array}$ & $\begin{array}{l}125 \\
6 \% \\
\end{array}$ & $\cdots$ \\
\hline I6 States. & 37,132 & $\begin{array}{r}29,033 \\
78 \%\end{array}$ & $\begin{array}{r}5,415 \\
15 \%\end{array}$ & $\begin{array}{r}2,472 \\
7 \%\end{array}$ & $\begin{array}{l}391 \\
1 \%\end{array}$ & $\begin{array}{c}212 \\
\text { Less than } \\
1 \%\end{array}$ \\
\hline
\end{tabular}




\section{APPENDIX}

C. Middle Western States

\begin{tabular}{|c|c|c|c|c|c|c|}
\hline & $\begin{array}{l}\text { Total } \\
\text { PENal } \\
\text { Popu- } \\
\text { LAtion }\end{array}$ & $\begin{array}{c}\text { Produc- } \\
\text { TIVELY } \\
\text { EM- } \\
\text { PLOYED }\end{array}$ & $\begin{array}{c}\text { EM- } \\
\text { PLOYED } \\
\text { ON } \\
\text { MAINTE- } \\
\text { NANCE }\end{array}$ & $\begin{array}{l}\text { Not } \\
\text { WORK- } \\
\text { ING }\end{array}$ & $\begin{array}{l}\text { DEFI- } \\
\text { NITELY } \\
\text { IDLE }\end{array}$ & $\begin{array}{l}\text { Not } \\
\text { Accounted } \\
\text { FOR }\end{array}$ \\
\hline Illinois. & 6,517 & $\begin{array}{r}4,006 \\
62 \%\end{array}$ & $\begin{array}{r}2,028 \\
31 \%\end{array}$ & $\begin{array}{l}483 \\
7 \%\end{array}$ & $\begin{array}{r}63 \\
1 \%\end{array}$ & $\cdots$ \\
\hline Indiana.. & 4,199 & $\begin{array}{r}2,642 \\
63 \% \\
\end{array}$ & $\begin{array}{r}1,429 \\
34 \% \\
\end{array}$ & $\begin{array}{l}128 \\
3 \% \\
\end{array}$ & $\cdots$ & $\cdots$ \\
\hline Iowa...... & 2,310 & $\begin{array}{r}1,402 \\
61 \% \\
\end{array}$ & $\begin{array}{r}750 \\
32 \% \\
\end{array}$ & $\begin{array}{l}158 \\
7 \% \\
\end{array}$ & ? & $\ldots$ \\
\hline Kansas.. & $2,88 \mathrm{I}$ & $\begin{array}{r}\mathrm{I}, 390 \\
48 \% \\
\end{array}$ & $\begin{array}{r}1,158 \\
40 \% \\
\end{array}$ & $\begin{array}{l}177 \\
6 \% \\
\end{array}$ & $\cdots$ & $\begin{array}{l}156 \\
5 \% \\
\end{array}$ \\
\hline Michigan. & 6,550 & $\begin{array}{r}2,724 \\
42 \%\end{array}$ & $\begin{array}{r}2,110 \\
32 \%\end{array}$ & $\begin{array}{r}1,716 \\
26 \%\end{array}$ & $\begin{array}{r}1,237 \\
19 \%\end{array}$ & $\cdots$ \\
\hline Minnesota. & 2,117 & $\begin{array}{r}\mathrm{I}, 177 \\
56 \% \\
\end{array}$ & $\begin{array}{r}835 \\
39 \% \\
\end{array}$ & $\begin{array}{l}105 \\
5 \% \\
\end{array}$ & $\cdots$ & $\cdots$ \\
\hline Missouri. & 3,785 & $\begin{array}{r}2,446 \\
65 \% \\
\end{array}$ & $\begin{array}{r}855 \\
23 \% \\
\end{array}$ & $\begin{array}{r}394 \\
10 \% \\
\end{array}$ & $\begin{array}{l}312 \\
8 \%\end{array}$ & $\begin{array}{r}90 \\
2 \% \\
\end{array}$ \\
\hline Nebraska.. & 1,028 & $\begin{array}{r}722 \\
70 \% \\
\end{array}$ & $\begin{array}{r}249 \\
24 \% \\
\end{array}$ & $\begin{array}{r}57 \\
6 \% \\
\end{array}$ & $\cdots$ & $\cdots$ \\
\hline North Dakota & 309 & $\begin{array}{r}115 \\
37 \% \\
\end{array}$ & $\begin{array}{r}182 \\
59 \% \\
\end{array}$ & $\begin{array}{r}12 \\
4 \% \\
\end{array}$ & $\cdots$ & $\cdots$ \\
\hline Ohio......... & 8,234 & $\begin{array}{r}3,288 \\
40 \% \\
\end{array}$ & $\begin{array}{r}2,692 \\
33 \% \\
\end{array}$ & $\begin{array}{r}1,752 \\
21 \% \\
\end{array}$ & $\begin{array}{r}\mathrm{I}, 243 \\
\mathrm{I} 5 \% \\
\end{array}$ & $\begin{array}{l}502 \\
6 \% \\
\end{array}$ \\
\hline South Dakota & 386 & $*$ & $\begin{array}{r}73 \\
16 \% \\
\end{array}$ & $\begin{array}{r}170 \\
47 \% \\
\end{array}$ & $\begin{array}{c}170^{*} \\
47 \% \\
\end{array}$ & $\begin{array}{r}143 \dagger \\
37 \% \\
\end{array}$ \\
\hline Wisconsin... & $\mathrm{I}, 53 \mathrm{I}$ & $\begin{array}{r}1,069 \\
70 \% \\
\end{array}$ & $\begin{array}{r}410 \\
27 \% \\
\end{array}$ & $\begin{array}{r}52 \\
3 \% \\
\end{array}$ & $\cdots$ & $\cdots$ \\
\hline I2 States. & 39,847 & $\begin{array}{r}20,981 \\
53 \%\end{array}$ & $\begin{array}{r}12,771 \\
32 \%\end{array}$ & $\begin{array}{r}5,204 \\
13 \%\end{array}$ & $\begin{array}{r}3,025 \\
8 \%\end{array}$ & $\begin{array}{l}891 \\
2 \%\end{array}$ \\
\hline
\end{tabular}

* Twine plant not running at time of visit

$\dagger$ Some if not all employed on maintenance 
306

\section{APPENDIX}

D. Western States

\begin{tabular}{|c|c|c|c|c|c|c|}
\hline & $\begin{array}{l}\text { Total } \\
\text { PENal } \\
\text { Popu- } \\
\text { LAtion }\end{array}$ & $\begin{array}{c}\text { ProdUC- } \\
\text { TIVELY } \\
\text { EM- } \\
\text { PLOYED }\end{array}$ & \begin{tabular}{|c|} 
EM- \\
PLOYED \\
ON \\
MAINTE- \\
NANCE \\
\end{tabular} & $\begin{array}{l}\text { Not } \\
\text { WORK- } \\
\text { INO }\end{array}$ & $\begin{array}{l}\text { DEFI- } \\
\text { NITELY } \\
\text { IDLE }\end{array}$ & $\begin{array}{l}\text { Not } \\
\text { AcCOUNTED } \\
\text { FOR }\end{array}$ \\
\hline Arizona.. & 543 & $\begin{array}{r}118 \\
22 \%\end{array}$ & $\begin{array}{r}393 \\
72 \% \\
\end{array}$ & $\begin{array}{r}32 \\
6 \% \\
\end{array}$ & $\cdots$ & $\cdots$ \\
\hline California..... & 6,669 & $\begin{array}{r}4,023 \\
60 \% \\
\end{array}$ & $\begin{array}{r}2,521 \\
38 \% \\
\end{array}$ & $\begin{array}{l}125 \\
2 \%\end{array}$ & $?$ & $\cdots$ \\
\hline Colorado..... & 1,320 & $\begin{array}{r}558 \\
42 \% \\
\end{array}$ & $\begin{array}{r}558 \\
42 \%\end{array}$ & $\begin{array}{r}184 \\
14 \%\end{array}$ & $?$ & $\begin{array}{r}20 \\
2 \%\end{array}$ \\
\hline Idaho......... & 422 & $\begin{array}{r}290 \\
69 \%\end{array}$ & $\begin{array}{r}93 \\
22 \% \\
\end{array}$ & $\begin{array}{r}39 \\
9 \% \\
\end{array}$ & $\begin{array}{r}10 \\
2 \%\end{array}$ & $\cdots$ \\
\hline Montana..... & 462 & $\begin{array}{r}177 \\
38 \%\end{array}$ & $\begin{array}{r}156 \\
34 \%\end{array}$ & $\begin{array}{r}129 \\
28 \%\end{array}$ & $\begin{array}{r}129 \\
28 \%\end{array}$ & $\cdots$ \\
\hline Nevada........ & 198 & $\ldots$ & $\begin{array}{r}90 \\
45 \% \\
\end{array}$ & $\begin{array}{r}108 \\
55 \% \\
\end{array}$ & $\begin{array}{r}108 \\
55 \% \\
\end{array}$ & $\cdots$ \\
\hline New Mexico.. & 401 & $\begin{array}{r}303 \\
76 \% \\
\end{array}$ & $\begin{array}{r}77 \\
19 \% \\
\end{array}$ & $\begin{array}{r}21 \\
5 \%\end{array}$ & $\ldots$ & $\cdots$ \\
\hline Oregon........ & 711 & $\begin{array}{r}255 \\
36 \% \\
\end{array}$ & $\begin{array}{r}241 \\
34 \% \\
\end{array}$ & $\begin{array}{r}215 \\
30 \% \\
\end{array}$ & $\begin{array}{r}193 \\
27 \% \\
\end{array}$ & $\cdots$ \\
\hline Utah......... & 234 & $\begin{array}{r}119 \\
51 \% \\
\end{array}$ & $20 \%$ & $\begin{array}{r}69 \\
29 \%\end{array}$ & $\begin{array}{r}69 \\
29 \%\end{array}$ & $\cdots$ \\
\hline Washington... & 1,672 & $\begin{array}{l}605 \\
36 \%\end{array}$ & $\begin{array}{r}628 \\
38 \%\end{array}$ & $\begin{array}{r}439 \\
26 \%\end{array}$ & $\begin{array}{r}340 \\
20 \%\end{array}$ & $\cdots$ \\
\hline Wyoming..... & 295 & $\begin{array}{r}211 \\
72 \% \\
\end{array}$ & $\begin{array}{r}65 \\
22 \%\end{array}$ & $\begin{array}{r}19 \\
6 \%\end{array}$ & $\cdots$ & $\cdots$ \\
\hline I I States & 12,927 & $\begin{array}{r}6,659 \\
52 \%\end{array}$ & $\begin{array}{r}4,868 \\
37 \%\end{array}$ & $\begin{array}{r}1,380 \\
11 \%\end{array}$ & $\begin{array}{l}849 \\
7 \%\end{array}$ & $\begin{array}{c}20 \\
\text { Less than } \\
1 \%\end{array}$ \\
\hline
\end{tabular}




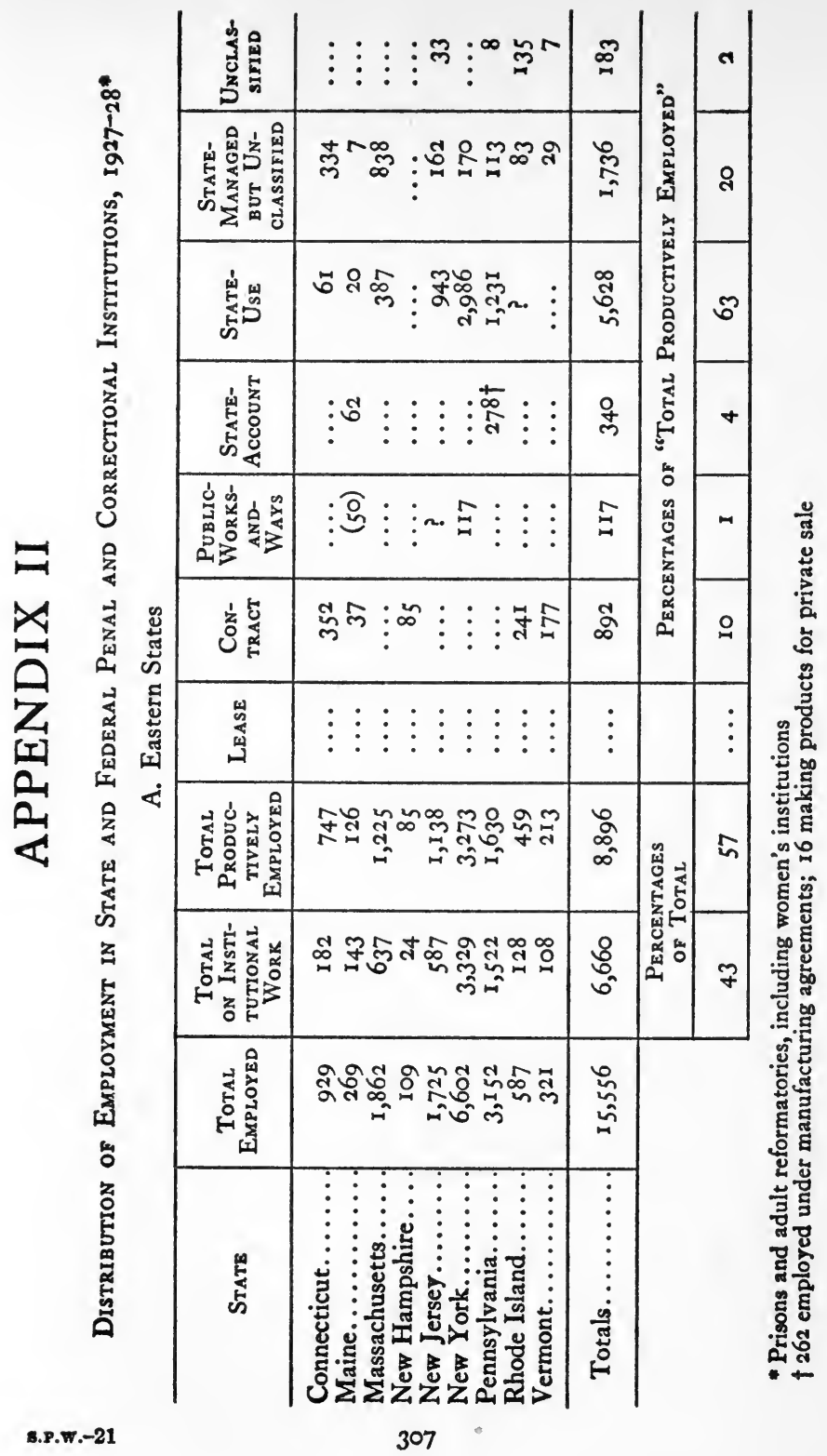




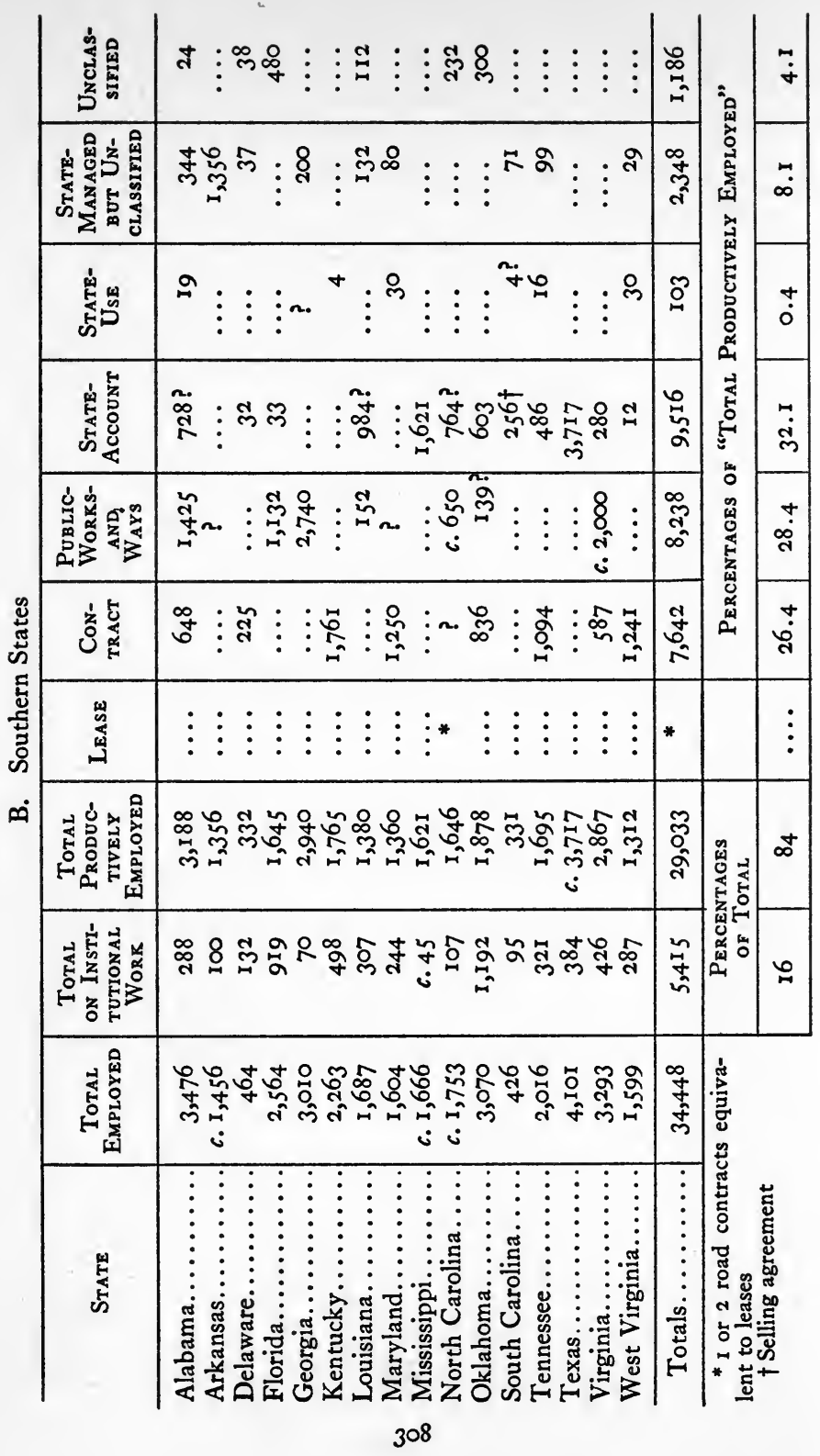




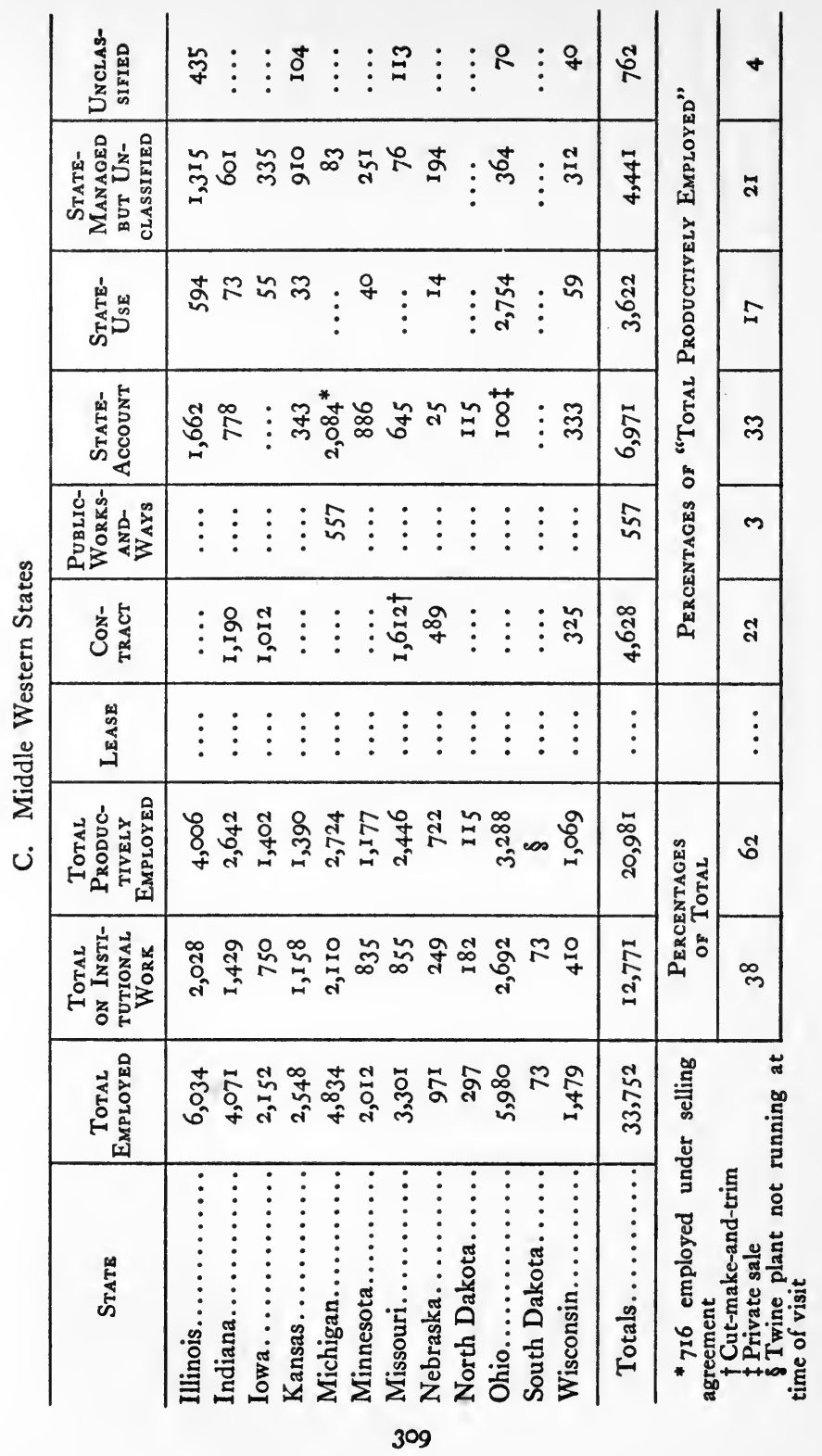




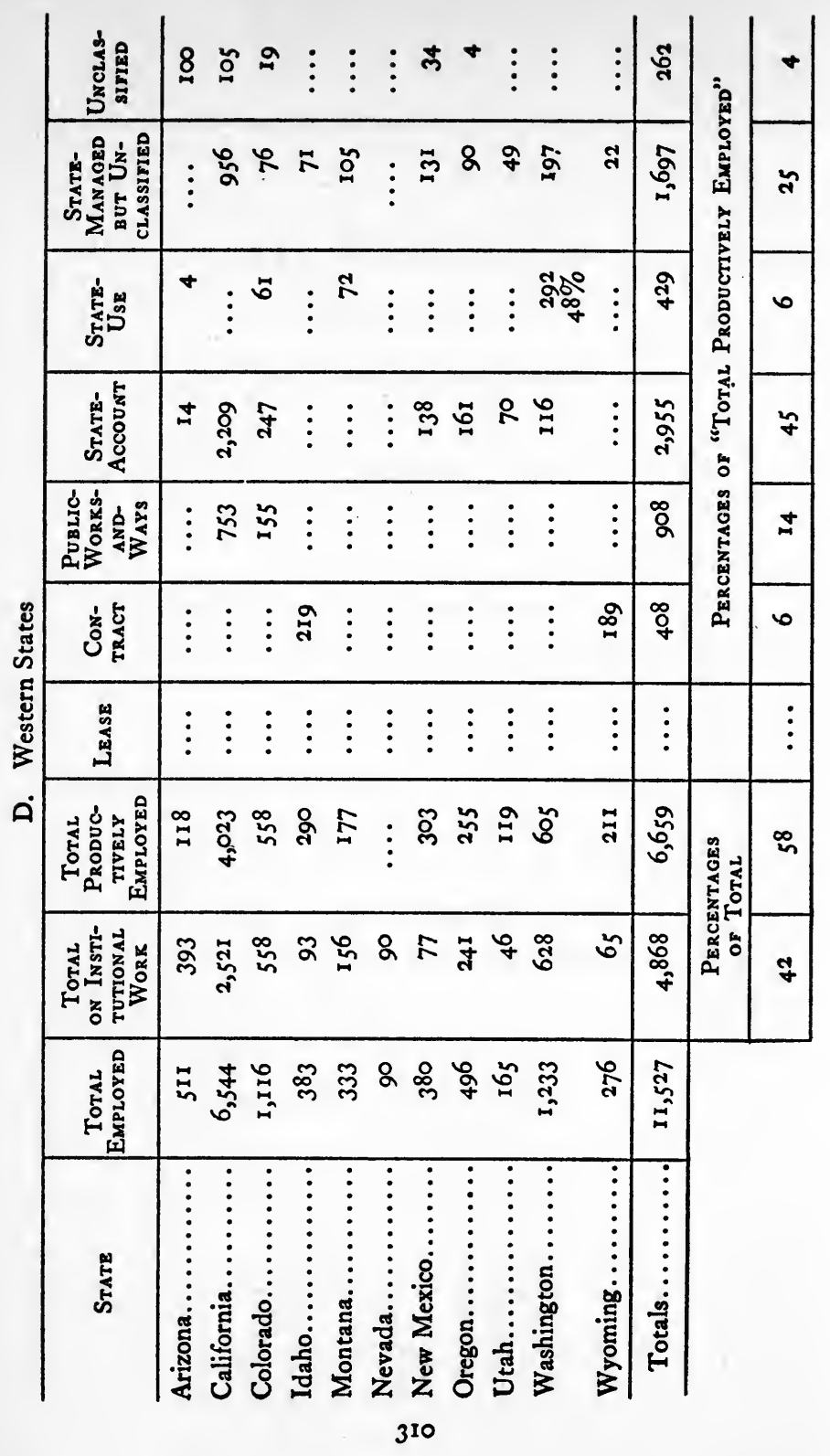




\title{
APPENDIX III
}

\author{
QUESTIONNAIRE
}

Sent to Welfare Department, Board of Charities and Corrections, or Similar Agency in Each State

I. What was the total average population of all county jails, workhouses, and houses of correction, combined, for the last fiscal year?

2. Of this number, how many were

(a) under sentence?

(b) awaiting trial?

3. Approximately how many of the prisoners were employed

(a) in maintenance work?

(b) in road work?

(c) in farm work?

(d) in industrial work by hand?

(e) in industrial work by machine?

4. Approximately how many hours a day were they employed?

5. Were the products of their work disposed of

(a) in the institution?

(b) in other public institutions?

(c) on the open market?

6. Were they paid for their work?

7. If so, at what rate?

Signature

Title

State 



\section{BIBLIOGRAPHY}

(The following list includes all sources to which reference is made in the text or tables, with the addition of a few specific titles which seemed particularly worth including, and one or two general works which point the way to available material not listed here. Only references bearing upon prison labor in the United States are included. In general, titles dated earlier than 1920 have been omitted, and emphasis has been placed upon titles appearing since I925. The older literature on the subject may be reached through the bibliographical and general titles mentioned.)

\section{Bibliographies General and Specific}

\section{Hart, Myrtle Grace}

Farm colonies for misdemeanants: a bibliography. Jour. Crim. Law and Crim'l'gy, 17:626-39 (Feb. 1927).

Compiled 1925, as partial requirement for diploma, Library School, Univ. of Wisconsin. No entries later than 1923 or 1924; most entries before 1920 .

\section{Kuhlman, Augustus Frederick}

A guide to material on crime and criminal justice; a classified and annotated union catalog of books, monographs, pamphlets, and of periodical articles relating to criminology, the administration of criminal justice, criminal law, police, judicial organization, criminal procedure, punishment, institutional treatment of offenders in prisons, jails and reformatories, pardon, parole, probation, the juvenile court, and crime prevention. Prepared by Augustus Frederick Kuhlman for the Committee on Survey of Research on Crime and Criminal Justice, of the Social Science Research Council.. New York: Wilson, 1929.

Material published or in manuscript, cataloged in at least one of I3 large libraries before Jan. I, I927. Consult serial nos. I-I33, 896I-9099, 932I-432, 9482-I0975, 10342-64, I0496-850, 10976-I IO92, IIII 8-I 9, II I 20-25, III 56-224, I I 281-99, II 33637, $11364-431,11469-506$.

Sellin, Thorsten, ed.

Bibliography: The science of criminology. Jour. Crim. Law and Crim'l'gy, I8:147-58, 295-318, 45I-84, 629-39 (May 
1927-Feb. 1928); 19:118-58, 290-320, 456-508, 656-91 (May 1928-Feb. 1929).

Current books, pamphlets, articles, both American and foreign; classified. Consult sections on institutional penal treatment and the administration of criminal justice.

Stone, Edna L.

Recent references on convict labor in the United States. (In Prison industries, Washington, 1929; appendix E, 110-32.)

Quite comprehensive for years I 19 15-28, approximately.

\section{Organizations, Periodicals, and Yearbooks}

\section{American Institute of Criminal Law and Criminology} Journal of criminal law and criminology. (Formerly: Journal of the American Institute of Criminal Law and Criminology.)

Published bi-monthly; annual index of articles, notes, and reviews.

American Prison Association (135 E. 15th St., New York, N.Y.)

Proceedings, 1920-30.

Title varies: Proceedings of the annual congress of the American Prison Association ... I924. Proceedings of the 59th annual congress of the American Prison Association; Toronto, Canada ... I929.

Partial contents:-I92I: Votaw, Albert H. Should the products of prison industries be exclusively used in institutions supported wholly or partially by the state?-1923: Butler, Amos W. The county jail and the misdemeanant prisoner.-1924: Discussion of prison industries, I31-57.-1925: Hart, Hastings $H_{\text {., }}$ and others. Report of the committee on lock-ups, municipal and county jails, 179-206.-1926: Discussion of prison industries, I 46-65.-McCullough, E. W. Manufacturing in prisons - some observations of business, 242-53.-Fishman, J. F. Employment for county jail prisoners, 287-99.-I 927: Discussion, 247-6r.1928: Discusson, 61-8.-Cox, William B. Convict labor in the South, 207-1 4.-Lee, Oscar. After prison - what? 351-60.Garrett, Paul W. Some observations on prison control, 40I-9.1929: Erskine, George C. President's address, 2-8.-Ellis, William J. Discussion of classification, 189-94.-I 1930: Bagley, Edward C. R. Operation of state use law of Massachusetts, $130-5$. - Bennett, J. V. Prison industries, $135-43$. - Discussion, I 43-56. -Jackson, Harry H. The new prison at Jackson, Michigan; its plan of construction and program of treatment, 278-85. - Bates, Sanford. Modern trends in the development of Federal and state correctional programs, 377-9I. 
American Year Boox; a Record of Events and Progress, 1925-30. New York: Macmillan, 1926-7; Doubleday, Doran, 1928; Amer. Year Book Corp., 1929-31. Albert Bushnell Hart, ed., William M. Schuyler, assoc. ed.

Articles on "Prisons and penal conditions," etc.

National Committee on Prisons and Prison Labor (250 West $57^{\text {th }}$ St., New York, N. Y.)

Annual reports, 1925-31. New York: 1925-3I.

Many pamphlets and leaflets also published.

National Society of Penal Information, Inc. (i 4 E. 3oth St., New York, N. Y.)

News bulletin.

Published bi-monthly.

Pennsylvania Committee on Penal Affairs (3i S. Juniper St., Philadelphia, $\mathrm{Pa}$.)

Penal affairs.

Published irregularly. Many other pamphlets and studies.

Pennyslvania Prison Society (3i i S. Juniper St., Philadelphia, $\mathrm{Pa}$.)

Prison journal.

Published quarterly.

Prison Association of New York (135 E. 15th St., New York, N. Y.)

Annual reports, 1924-30. Albany: J. B. Lyon, 1925-31.

Always contain data on New York prisons.

Prison Labor. The Annals, vol. 46, whole no. I35 (March, I9r3). Philadelphia: Amer. Acad. Pol. and Soc. Sci., I9r3.

Partial contents:-Whitin, E. Stagg. Industrial penology.Mitchell, John. The wage-earner and the prison worker.Donaghey, George W. Why I could not pardon the contract system.-Tynan, Thomas W. Prison labor on public roads.Pratt, Joseph Hyde. Convict labor in highway construction.Cooley, Harris R. Good opportunities for prison labor.-Page, Edwin L. New Hampshire's experiment in using prison labor to support paupers.

Social Work Year Book, 1929. New York: Russell Sage Foundation, 1930. F. S. Hall and Mabel B. Ellis, ed.

Articles on prison conditions and prison labor. 
Barnes, Harry Elmer

\section{General}

Economics of American penology as illustrated by the experience of the state of Pennsylvania. Jour. Pol. Econ., 29:617-42 (Ig21).

The various industrial ventures in connection with economic and industrial developments on the outside.

The evolution of penology in Pennsylvania; a study in American social history. Indianapolis: Bobbs-Merrill, 1927.

"The systems of industry and maintenance in the state penitentiaries," 22I-8I.

Bennett, J. V.

The outlook for prison labor. Amer. Prison Assoc., Proceedings (1930), $135-43$.

Economic difficulties confronting prison labor, and situation in Federal institutions.

Breckinridge, Sophonisba P.

Public welfare administration in the United States: Select documents. Chicago: Univ. of Chicago Press, [C1927].

Prisons and their administration, 62-7, 76-89, 105-9, II 9-23, 252-8, 343-50, 439-44, 616-23. Convict labor, 549-54, 623-5. The county jail, $57-62,76-89,645-52$.

Cass, Edward R.

Prison labor. (Paper read at National Conference on Reduction of Crime, 1927. Cf. A full report of the proceedings of the national conference on the reduction of crime, below; also New York Prison Association, 83rd annual report (I927), 81-8.

Excellent brief statement of the problem as a whole.

Cleghorn, Sarah, and Fisher, Dorothy Canfield Miss Ross' Girls. Survey, 66:429-34 (I93I).

Sympathetic write-up of Riverside, the Vermont State Prison and House of Correction for Women; data on earnings of the laundry, and its importance.

General Federation of Women's Clubs. Department of Public Welfare

Program: Division of correction, 1930. n.p., $20 \mathrm{f}$.

Short presentation of the subject for the uninitiated.

Governors' Conference, I930

Official proceedings of the twenty-second annual conference of governors held at Salt Lake City, Utah, June 30, July I 


\section{BIBLIOGRAPHY}

and 2, 1930, and at Zion Canyon Lodge, Utah, July 3, 1930: Complete stenographic record. Issued as supplement to The United States Daily, 5, no. 112 , sec. 2, July 14, 1930.

General discussion centering upon Hawes-Cooper Bill and its implications, 18-24.

Hart, Hastings H.

Address before the Economics Club of New York. The Consensus, I $5: 28-35$ (July 1930).

A few pertinent facts on prison labor in New York.

Jackson, Henry Theodore

Prison labor. Jour. Crim. Law and Crim'l'gy, 18:218-68 (Aug. 1927).

M.A. thesis, Univ. of Iowa.

Gillin, John Lewis

Criminology and penology. New $\mathrm{Yo}_{\mathrm{o}} \mathrm{k}$ and London: Century, [cig26]. (Century social science series.)

"Prison labor," ch. 20. "Some unsettled prison labor problems," ch. 2I. Bibliography following each chapter.

JafFray, Julia K., ED.

The prison and the prisoner; a symposium ... Boston: Little, Brown, I9I 7 .

Partial contents:-Kirchwey, Karl W. The prisoner - ward or slave? ch. 3.-Dean, Arthur D. Industrial training for the prisoner, ch. 7.-Lovely, Collis. The union man and the prisoner, ch. 9 .

Jensen, C. C.

Our convict slaves. Atlantic Monthly, 137:591-603 (May 1926).

Prison plantations in Texas.

Klein, Philip

Prison methods in New York state; a contribution to the study of the theory and practice of correctional institutions in New York state. New York: Columbia Univ., Longmans, Green, agents, 1920. (Studies in history, economics and public law, edited by the faculty of political science of Columbia University, vol. 90, no. I.)

"Classification and segregation," ch. 4. "Labor," ch. 8 and 9. 
Lawes, LewIS E.

Life and death in Sing Sing. Garden City, N. Y.: Doubleday, Doran, 1928.

Present routine, and history of the institution.

Lewis, Burdette G.

The labor phase of correctional treatment. Nat. Conf. of Social Work, Proceedings (1919), 107-12.

An outline of the problem.

Lewisohn, Adolph

Prisons and prison labor. Century, 106:399-404 (July 1923).

Classification, wages, marketing.

Liepmann, M.

American prisons and reformatory institutions; a report. Translated by Charles A. Fiertz. Mental Hygiene, 12:2253I5 (April 1928).

Illuminating comments on all phases of American penological development, including prison labor, from a European viewpoint.

Mohler, Henry Calvin

Convict labor policies. Jour. Crim. Law and Crim'l'gy, 15:530-97 (Feb. 1925).

M.A. thesis, Univ. of Wisconsin.

National Crime Commission

A full report of the proceedings of the national conference on the reduction of crime, called by the National Crime Commission; New Willard Hotel, Washington, D. C., November 2nd and 3rd, 1927. New York: National Crime Commission, 218 p. mimeographed.

Partial contents:- - Lewisohn, Sam. Prison labor problem, 90-2.Cass, E. R. Prison labor, 93-8.-Allison, A. F. The manufacturers' viewpoint on prison labor, 99-104.-McGrady, Edward F. The attitude of organized labor, I06-8.-Hodges, LeRoy. The states' use system, IO9-1 4.-Discussion by E. W. McCullough, John A. Shaughnessy, A. H. MacCormick, Colonel Lewis.

National Society of Penal Information

Handbook of American prisons: 1926. Ed. by Paul W. Garrett and Austin H. MacCormick. New York and London: Putnam, 1926.

Detailed reports covering employment conditions in 52 prisons. 


\section{National Society of Penal Information}

Handbook of American prisons and reformatories: 1929. Ed. by Paul W. Garrett and Austin H. MacCormick. New York: National Society of Penal Information, [c1929].

Detailed reports covering employment conditions in 103 prisons and reformatories.

Pierce, John M.

Prison made products in California. Tax Digest, 8:163-6 (May 1930).

Prison Labor. Saturday Evening Post, 203:26 (Sept. 6, I930).

Editorial summarizing both sides of competition question.

Robinson, Louis N.

Penology in the United States. Philadelphia: Winston, 1921.

"Prison labor," ch. 8. "Compensation of prisoners," ch. 9.

Ross, Lena C.

Riverside - the women's reformatory at Rutland. Vermont Highways, June, 1930, I4-18.

Laundry and maintenance work at the Vermont State Prison and House of Correction for Women.

Sutherland, Edwin H.

Criminology. Philadelphia and London: Lippincott [c1924]. (Lippincott sociological series.)

"Prisons: Convict labor," ch. 19, with "Suggested readings."

Tannenbaum, Frank

Wall shadows. New York: Putnam, 1922.

Estimate of idleness, criticism of existing industrial set-up; suggestions and comments by the way.

Whitin, E. Stagg

An analysis of the prison problem. Jour. Crim. Law and Crim'l'gy, 20: 519-32 (Feb. 1930.)

Section on employment.

\section{Federal Publications}

United States. Bureau of the Census.

Biennial census of manufactures: 1923. Washington, Govt. printing office, 1926 .

Prisoners: 1923; crime conditions in the United States as reflected in census statistics of imprisoned offenders. Washington: Govt. printing office, 1926 . 
United States. Bureau of the Census.

Prisoners in state and Federal prisons and reformatories: 1926; statistics of prisoners received and discharged during the year, for state and Federal penal institutions. Washington: Govt. printing office, 1929.

Prisoners in state and Federal prisons and reformatories: 1927; statistics of prisoners received and discharged during the year for state and Federal penal institutions. Washington: U. S. Govt. printing office, I 93 I.

- Bureau of Corporations.

Farm-machinery trade associations; March I5, 1915. Washington: Govt. printing office, I9I 5 .

"Opposition to prison factory legislation," I07-1 IO.

- Bureau of Foreign and Domestic Commerce. Commerce Yearbook: 1923. Washington: Govt. printing office, 1924 .

Commerce Yearbook: 1924. Washington: U.S. govt. printing office, 1925 .

Commerce Yearbook: I929. Washington: U.S. govt. printing office, 1929.

Vol. I: United States.

Prison industries. Washington: U. S. govt. printing office, 1929. (Domestic commerce series, no. 27.)

The latest official study, supplementing next title.

- Bureau of Labor Statistics.

Convict labor in 1923. Washington: Govt. printing office, 1925. (Bulletin no. 372.)

Comprehensive statistics on labor in state and Federal institutions. Part II: Letters from interested manufacturers, protesting prison competition. Part III: Digest of state and Federal laws on subject.

State convict labor legislation. Monthly Labor Review, 28:126-37 (March 1929).

Summary of legislation.

- Bureau of Prisons.

Report to the President, April 27, 1931. I5 p. mimeographed.

Development of Federal correctional system during past year.

COMMISSIONER OF LABOR.

Second annual report: Convict labor. Washington: Govt. printing office, 1887 . 


\section{BIBLIOGRAPHY}

United States. Commissioner of Labor.

Convict labor. Bulletin of the Department of Labor, no. 5 (July I896), 443-78.

Twentieth annual report (1905): Convict labor. Washington: Govt. printing office, 1906.

63rd Congress, 2nd Session.

Federal and state laws relating to convict labor. Washington: Govt. printing office, I9I4. (Senate document no. 494.)

Some data on prison products, etc., in addition to legislative summary.

- 69th Congress. House of Representatives.

Convict labor: Hearings before the Committee on Labor . . . on H. R. 8653 ... March . . A April ..., rg26. Washington: Govt. printing office, 1926.

Convict labor: Hearings before the Committee on Labor . . . on H. R. 8653, a bill to divest goods, wares, and merchandise manufactures, produced, or mined by convicts or prisoners of their interstate character in certain cases; March 5, 12, 20, 25, 26, 31, April I and 16, 1926. Washington: Govt. printing office, 1926 .

Competition of prison goods with free goods.

\section{- 7oth Congress. House of Representatives.}

Federal penal and reformatory institutions: Hearings before the Special Committee . . ., pursuant to H. Res. 233, Seventieth Congress, First Session, directing a committee to make a survey and report upon the care and employment of Federal prisoners, ... January 7, I929, to January I5, 1929. Washington: U. S. Govt. printing office, 1929.

Appendix I: Bennett, J. V. The Federal penal and correctional problem, 173-207. Appendix II: Bennett, J. V., and Thomas, A. G. Interim report on analysis of government purchases for prison industries program, 207-23. Appendix III: Butler, Amos W. Prisoners and prisons, 223-63.

Convict labor: Hearings before the Committee on Interstate Commerce ... on S. 1940, a bill to divest goods, wares, and merchandise manufactured, produced, or mined by convicts or prisoners of their interstate character in certain cases; February 7, 8, 9, and 17, 1928. Washington: U. S. Govt. printing office, 1928 . 
United States. Department of Commerce and Labor. Statistical abstract of the United States: 1909; thirty-second number. Washington: Govt. printing office, Igro.

\section{ENFORCEMENT.}

Report on penal institutions, probation and parole. Washington: U. S. Govt. printing office, I93I.

"Overcrowding," I I-I 4; "Idleness," I4-I 5. "Classification," 58-79. "Labor and Industry," 80-1 IO. The Report of the Advisory Committee on Penal Institutions, Probation and Parole, printed here also, contains section on "Prison Industries and Labor," 253-67.

This important study was released too late for more than cursory reading in connection with the present volume.

\section{Legislation}

Clark, L. D.

(Cf. "Federal Publications" also)

Labor laws and court decisions; convict labor. Monthly Labor Review, 18:655-6 (1924).

Legislation concerning competition.

Commons, John R., and Andrews, John B.

Principles of labor legislation. New York: Harper, [c1920]. Industries affected by competition and types of laws governing convict labor, pp. $78 \mathrm{ff}$.

California. Laws, Statutes, etc.

Laws relating to crime and administration of criminal law, passed by California Legislature in I929. Sacramento: California Crime Commission, I929.

Massachusetts. Laws, Statutes, etc. Acts of 1928 .

Wages for prisoners, ch. 387 .

Minnesota. Laws, Statutes, etc. Laws of 1929.

Ch. ${ }^{8}{ }^{8}$ concerns branding of prison-made goods.

New Jersey. Laws, Statutes, etc.

Laws of New Jersey relating to the charitable and correctional institutions and agencies, boards and commissions, including the State Board of Control of Institutions and Agencies; Chapter 147, I aws of I9I8, and amendments and supplements; public welfare statutes, including revision of poor law, chapter I32, Laws of 1924. Trenton: New Jersey State Prison Print, I929. 
New Jersey. Laws, Statutes, etc.

Laws of 1931 .

Ch. 235 forbids importation of convict-made goods into the state.

North Carolina. Laws, Statutes, etc.

State road law. (Senate bill no. 338, Session 1931.)

Prisoner road work placed under jurisdiction of State Highway

Commission; county road camps abolished.

Pennsyluania. Laws, Statutes, etc.

Laws of I93I.

No. 308 forbids sale of prison-made goods (manufactured outside of the state) on the open market.

Schwartz, Arthur H.

Legal aspects of convict labor. Jour. Crim. Law and Crim'l'gy, 16:272-7 (Aug. 1925).

Main outlines of legislation on subject, and some court decisions.

United States. Laws, Statutes, etc.

Public no. 669, 7oth Congress (H. R. 7729).

The Hawes-Cooper Bill.

Public no. 271, 71st Congress (H. R. 7412).

Employment of Federal prisoners.

Whitin, E. Stagg

Prison legislation in 1930. Am̄er. Bar Assoc. Jour., 17:303-5 (1931).

The Various Systems of Prison Labor

After Florida, Alabama. Nation, i17:3i (July iI, 1923).

Alabama too should end the lease system.

\section{Anderson, Nels}

"Stir" slaves; the prison labor contractor; the state-use system. Outlook, I 49: 492-4, 540-2 (I928).

An interview with the head of the most important firm in the prison contract field; difficulties of state-use and states-use systems; labor and trade opposition to prison labor.

Associates for Government Service

Report to the industrial relations committee of the Philadelphia Chamber of Commerce; October I, 1926. New York: Associates for Govt. Service. II p.

Report of activities in securing coöperation of labor and trade groups in reorganizing Pennsylvania prison industries. $\mathrm{C} f$. also Pennsylvania Secretary of Welfare, Reports, 1925-26 and 1927-28. 
Contract Labor in Prisons. Welfare Magazine (Illinois Dept. of Public Welfare), I 7: 77-9 (April 1926).

Description of Wisconsin prison industries.

Eastern-southern Conference on State Institutional LABor. New York: National Committee on Prisons and Prison labor, 1930. $8 \mathrm{p}$.

Projected organization of states-use system.

The End of Convict Leasing in Alabama. Literary Digest, 98: I I (July 21, I928).

Florida Makes a Beginning. Survey, 50:210 (May 15, 1923).

End of lease system reported.

Fundamental Principles for the Establishment of the

State Use System. New York: Nat. Com. on Prisons and

Prison Labor, 193I. 15 P.

O'Hare, Kate Richards

Human ostriches. Nation, I20:377-8 (1925).

In prison. New York: Knopf, I923.

Contract system at Missouri State Penitentiary in 1919-20.

The story of the "Big Yank." Reprinted from The American Vanguard, May, I924, reprint no. 42.

Iniquities of the contract labor trust.

The taxpayer's burden. World Tomorrow, 8:137-8 (May 1925).

Contract labor is subsidized labor.

Schwartz, Isaac Herman

Welcome to our chain gang! New Republic, 66:200-2 (April 8, I931).

County prisoners in Florida are leased to private lumber firms.

States to Decide on Prison Goods. The Business Week, Oct. I2, I929, IO-II.

Effects of Hawes-Cooper Bill.

Steiner, Jesse F., and Brown, Roy M.

The North Carolina chain gang; a study of county convict road work. Chapel Hill: Univ. of North Carolina Press, 1927. (University of North Carolina Social Study Series.)

Thorough study of the system and its economic and social aspects.

Strief, J. H.

Iowa prison industries. Bulletin of State Institutions (Iowa Board of Control), 39:186-90 (Oct. 1927).

Contract, state-account, and state-use systems. 


\section{BIBLIOGRAPHY}

Sullivan, J. J.

Prison labor. Tax Digest, 8:160-2 (May 1930).

State-account system in Minnesota.

Tynan, Thomas J.

Prison labor on public roads. Annals, 46:58-60 (March I9I3).

Public-works-and-ways system as originally tried in Colorado.

Whitin, E. Stagg

A plan for the interstate sale of prison products. Annals, 1 25:260-4 (May I926).

Self-supporting prisons. Jour. Crim. Law and Crim'l'gy, I5:323-9 (Aug. 1924).

The states-use system.

\section{Attitude of Trade Organizations}

Allison, A. F.

The manufacturers' viewpoint on prison labor. (In A full report of the proceedings of the national conference on the reduction of crime; cf. above.)

American Federation of Labor

Model amendments to solve prison labor competition; state legislatures have power to prohibit sale of penitentiary products from other states. Washington: American Federation of Labor, I930. I 2 p.

Report of proceedings of the 47 th-5oth annual convention, 1927-1930. Washington, 1927-1930.

\section{- Legislative Committee}

Report. American Federationist, 32:123-4 (Feb. I925).

National and state legislation against prison competition.

American Toy Manufacturer, Sept. I930.

Partial contents:-Convict contracts for toys loom as large threat to toy makers, IO-I I. - Rockwell, Sydney J. Prison made toys must go! I2-13.-Butler, Franklin. Toy machinery in Michigan Prison? 14-15.

Commons, John R., and Associates

History of labour in the United States. New York: Macmillan, I9I8.

History of labor opposition to prison goods, I: $155,282,344-7$, 369-70, 432, 443, 492, etc.

Edwards, A. M.

Labor legislation of Connecticut. Publications of the American Economic Association, 3rd series, vol. 7, no. 3 (1907).

"Convict labor," ch. IO. 
Establishment of Convict Labor System in Utah. Monthly

Labor Review, 33:176-7 (Aug. 1924).

Board of Correction prevented from contracting labor of prisoners.

Frayne, Hugh

The states use system. Jour. Crim. Law and Crim'l'gy, I2:330-8 (Nov. I921).

Development of the trade-union attitude towards prison competition.

Frey, John P.

The trade-union attitude towards prison labor. Annals, 46: 132-7 (March 1913).

Gompers, SAmuel

Contract prison labor - the shame of it. American Federationist, 28:497-500 (June 1921).

Effects of labor's efforts to restrict competition; prisoners' wages.

Governors' Conference, I925

Section meeting on prison administration and state coöperation in prison made goods: Excerpts from minutes. New York: Nat. Com. on Prisons and Prison Labor, I 5 p.

Examples of opposition to prison labor.

Hiller, E. T.

Labor unionism and convict labor. Jour. Crim. Law and Crim'l'gy, 5:851-79 (March 1915).

History of labor attitude.

Lovely, Collis

The state-use system. Annals, 46:138-4I (March 1914).

State-use system is the only one not competing unfairly with free labor.

McCullough, E. W.

Manufacturing in prisons - some observations of business. Amer. Prison Assoc., Proceedings (1926), 242-53.

Attitude of business organizations.

McGrady, Edward F.

The attitude of organized labor. (Cf. A full report of the proceedings of the national conference on the reduction of crime, above.)

Mrtchell, JohN

The wage-earner and the prison worker. Annals, 46:8-16 (March I9I3).

Trades affected by prison competition. 


\section{BIBLIOGRAPHY}

Potter, Ellen C.

Penal affairs in Pennsylvania. Prison Jour., 4:4-7 (April 1924).

Effects of labor and business opposition on prison industries.

Road Making by Convict Labor. Bulletin no. I of National Free Labor Association.

New York: 1913.

Stockton, Frank J.

The prison-labor policy of the Molders' Union. Jour. Crim. Law and Crim'l'gy, 7:129-30 (May IgI6).

Trinkle, E. LeE

Our prison industries; an address delivered before the Governors' Conference, ... I923. Richmond: Virginia Penitentiary Industrial Dept., 1923.

\section{Classification and Vocational Training}

BAKER, A. T.

The psychiatric clinic of Sing Sing prison. Psychiatric Quarterly, 2:464-5 (Oct. 1928).

Scope of the clinic's work.

Bates, Sanford

The care of defective delinquents at Bridgewater, Massachusetts. New York: Nat. Com. for Mental Hygiene, I924. (Reprinted from Mental Hygiene, 8:530-4; April 1924).

Christian, Frank L.

Segregation of psychopathic and mentally defective recidivists. Psychiatric Quarterly, 3:452-3 (Oct. I928).

Proportions of psychopaths and other abnormal cases at Elmira.

Classification of Prisoners (Report of a Preliminary Survey). Nat. Com. on Prisons and Prison Labor, 1931. I6 p.

Doll, Edgar A.

Classification of defective delinquents. Amer. Prison Assoc., Proceedings (1921), I77-81.

Classification of prisoners for purposes of training, work and parole. Amer. Prison Assoc., Proceedings (1922), 272-8.

The correlation of mental types with occupational assignment. Amer. Prison Assoc., Proceedings (1920), 306-13.

Psychology in the organization of prison industries. Bulletin of the Taylor Society, I I:219-23 (Oct. I926). 
Doll, Edgar A.

Some principles of correctional treatment. Jour. Crim. Law and Crim'l'gy, 18:197-206 (Aug. 1927).

Ellis, William J.

Classification as the basis for rehabilitation of prisoners. Nat. Soc. of Penal Inf., News Bulletin, 2:6-9 (Feb. 1931).

The New Jersey classification.

Glueck, Bernard

Concerning prisoners. New York: Nat. Com. for Mental Hygiene. (Reprinted from Mental Hygiene, 2:177-218; April 1918).

Glueck, Sheldon, and Glueck, Eleanor T. 500 criminal careers. New York: Knopf, 1930.

Case studies of men discharged from the Massachusetts Reformatory.

Hodder, Jessie D.

Disciplinary measures in the management of the psychopathic delinquent woman. Nat. Conf. Social Work, Proceedings (1920), 389-96.

Lewis, Burdette G.

Job analysis in prisons and state industries. New York Academy of Political Science, Proceedings, 9:700-9 (1922).

Occupational placements at New Jersey State Prison, Trenton.

Prison labor and state use in New Jersey; a practical prison program for industry. The Quarterly (Dept. Institutions and Agencies, N. J.), 3:5-23 (April 1925).

Fitting men and jobs together.

MacCormick, Austin H.

Education in penal institutions. Nat. Conf. Social Work, Proceedings (1929), 203-7.

Institutional industries in the light of vocational training.

The education of adult prisoners. New York: Nat. Soc. of Penal Information, I93I.

"Vocational education," ch. 9.

\section{OVERHOLSER, Winfred}

Psychiatric studies of jail prisoners in Massachusetts. (Reprinted from Amer. Assoc. for Study of the Feebleminded, Proceedings (1927). 
PALMER, LEO J.

The defective delinquent as a state problem. Psychiatric Quarterly, 1 :91-5 (Jan. 1927).

Proportion of defectives in correctional institutions.

A Plan for the Custody and Training of Prisoners Serving Sentences in the County Jails in New York State. [New York.? 1924.?]

Results of study of misdemeanants by Nat. Com. for Mental Hygiene.

Potter, Ellen C.

The influence of the mental hygiene movement on correctional institutions. Prison Jour., I I : I-3 (Jan. I93I).

New Jersey. Committee Appointed by Commissioner Burdette G. Lewis.

Report on state-use industries and employment of prisoners; based on questions presented to the state Department of Institutions and Agencies by Mr. Ernest Willvonseder, of the New York State Association on Prison Industries. 12 p. mimeographed. N. C.

Thayer, Walter N., Jr.

Institutions for defective delinquents. Penal Affairs, no. 22:4-1 2 (May 1930).

Six years' experience with the defective delinquent. Penal Affairs, No. 17:9-II (Jan. 1928).

Problems and accomplishments at Napanoch.

Williams, G. Croft

Crime and its treatment in South Carolina. Columbia: State Board of Public Welfare, I922. (Quarterly Bulletin, vol. 3 , no. 2.)

Results of study of 234 jail inmates by Nat. Com. for Mental Hygiene.

Wages and Compensation for Injuries

Andrews, John B.

Workmen's compensation for convicts. Amer. Labor Legislation Review, I 5 : 132-4 (June 1925).

Convict's status regarding industrial compensation, in New York. Bloodgood, Ruth S.

Welfare of prisoners' families in Kentucky. Washington: U. S. Govt. printing office, 1928. (Children's Bureau publication no. 182).

Efficacy of prisoners' wages in aiding their families. 
Convicts Under Workmen's Compensation Laws. Monthly Labor Review, 28: I 16-8 (March 1929).

Status in California, Maryland, Wisconsin.

Hymeman, Charles S.

The problem of providing incentive for prison labor. Jour. Crim. Law and Crim'l'gy, 17:603-21 (Feb. 1927).

Forms of wage.

Milliken, Ben H.

Four years' experience with convict wage. California Highways, $4: 3,6$ (Aug. 1927).

Expenses and wages; results of paying the men; figures, 1923-27.

By the superintendent of prison road camps.

Smith, W. Richmond

Can prisons be made self-supporting and inmates be paid adequate wages at the same time? Nat. Conf. Social Work, Proceedings (1921), 202-9.

Stutsman, Jesse O.

Curing the criminal. New York: Macmillan, I926.

"Prison industries and compensation," ch. 7.

Weyand, Lorenzo D.

The Pennsylvania plan of wage payment to prisoners. Jour. Crim. Law and Crim'l'gy, 18:277-83 (Aug. 1927).

A study of wage-payment to prisoners as a penal method. Chicago, I920. Reprinted in Jour. Crim. Law and Crim'l'gy, IO:558-9I (Feb. I920), II:96-106, 222-7I (May and Aug. I920).

Wage systems in prisons. Annals, 125:251-60 (May 1926).

Supplements his I 920 study.

\section{Industries and Products}

INSTITUTIONAL FARMS AND FARMING; PREPARED FOR THE Eastern-Southern Conference and New England ConFERENCE ON State Institutional Labor; PREliminary edition. New York: Nat. Com. on Prisons and Prison Labor, 1931. 16 p.

Massachusetts. Department of Correction.

A descriptive list of the articles and materials for use in the public institutions; September, 1929. $5^{2}$ p., il. 
National Committee on Prisons and Prison Labor. Committee on the Care and Training of Delinguent Girls. Industries for correctional institutions for women; report of a survey. New York: 1927. I44 P.

Detailed discussion of industries suitable for women prisoners, and directions for installation.

New York. Department of Correction. Division of Prison Industries.

Price list of standard articles. No. 8, effective July I, 1928.

- State Department of Correction.

Catalog of products manufactured in state institutions. I2th ed., loose-leaf, il. n.d.

- Superintendent of State Prisons.

Descriptive list of articles manufactured by the prison industries of the state of New York. Effective January I, 1926.

SLACK, E. S.

Industries within the walls of San Quentin. Tax Digest, 8:159-62 (May 1930).

The furniture shop.

\section{InSTITUTIONS FOR MisDEMEANANTS}

Booth, ERNEST

A Texas chain-gang. American Mercury, 12:306-15 (Nov. 1927).

A county road camp in Texas, 1924.

Brown, Emily Sophie

The county jail in Connecticut. Jour. Crim. Law and

Crim'l'gy, 17:369-74 (Nov. 1926).

Experience of the county commissioners with contract and stateaccount work at the New Haven jail.

Buckler, Helen

Attack the county jail. Good Housekeeping, Aug. 1930.

Much incidental comment on labor conditions, in an exposé of jails in various states.

The County Jail. New York: Nat. Com. on Prisons and Prison Labor, 1929. $20 \mathrm{p}$.

Contents:-Foreword.-Lewisohn, Adolph. Problem of the county jail.-Scott, B. L.-Industrial farms vs. schools of crime. - Bane, Frank. How Virginia is solving the jail problem.Kennedy, John S. J Jail situation in New York state.-Hodges, LeRoy. Why the jails must go. 
Fishman, Joseph F.

Crucibles of crime; the shocking story of the American jail. Written in collaboration with Vee Perlman. New York: Cosmopolis, I923.

Details of jail conditions the country over, with much evidence, implicit and explicit, of idleness.

Following through; state jail farm, sponsored by Department of Public Welfare, succeeds brilliantly. Public Welfare (Virginia State Board of Public Welfare), 4: I (Nov. 1927).

Consists of two quoted articles, "Before," and "After."

JaFFray, Julia K.

The Michigan jails; a report on a survey of the county jails in the state of Michigan, made by the Division of Problems of Delinquency, Michigan State Federation of Women's Clubs. 7 p., typewritten. (Also published by Nat. Com. on Prisons and Prison Labor, 1926.)

Contains comment on idleness.

Ohio Federation of Women's Clubs. Department of Public Welfare.

Report of the survey of the Ohio jails, made by Division of Adult Delinquency, Miss Irma Gerkins, chairman. n.p.

Conditions in 1926-27; comment on idleness; some work found.

Report of Commitee on Penal and Reformatory InstituTions. Indiana Bul. Char. and Cor., no. I49: I 25-3I (June 1927).

Effect of State Farm on county jail conditions.

Russell, C.

Welfare farm of the city of Toledo. American City, 23:610-2 Dec. 1920).

Descriptive.

Stern, LeON

The county prison of Allegheny county; with an analysis of detention and prison farm plans ... Philadelphia: Penna. Com. on Penal Affairs, I930.

The treatment of adult offenders and children by the courts of Beaver county, Pennsylvania. Philadelphia: Penna. Com. on Penal Affairs, Ig28.

[STERn, Leon]

The treatment of adult offenders and children by the courts of Berks County, Pennsylvania. Philadelphia: Penna. Com. on Penal Affairs [1928]. 
Stern, Leon

The treatment of adult offenders and children in Delaware county, Pennsylvania. Philadelphia: Penna. Com. on Penal Affairs, 1930.

Stern, Leon, and Dunham, Arthur

The work of the Juvenile Court of Allegheny County and the Juvenile Detention Home.

Stoecklein, E. V.

Correction farm supplants a city workhouse. Amer. City, 28: 149-5I (Aug. 1923). Dayton, Ohio.

Wheeler, Ruth Dunlop

The problem of the county jail. Jour. Crim. Law and Crim'l'gy, 15:620-30 (Feb. 1925).

Information on Lane County Jail, Oregon, for period 1923-25.

\section{Special. Studies and Investigations}

Hart, Hastings $\mathrm{H}$.

Two reports on the reorganization and reconstruction of the

New York City prison system. New York: Prison Assoc. of New York, 1925.

Contents: "Supplementary report, presented January 7, 1925."

"Original report, presented November 20, I924."

New York. Commission to Investigate Prison Administration and Construction.

Report ... presented to the Legislature . . ; Feb. I5, I93I. Addendum I: Preliminary report; presented to Governor Franklin D. Roosevelt . . . December 22, 1930.

Addendum II: Supplemental report; the classification of the prison inmates of New York state; submitted by V. C. Branham, M.D., Deputy Commissioner, New York State Department of Correction.

INDUSTRIES.

Analysis of prison vs. competing free made goods. (Chart CPI-I3.) Photostat copy.

Comparative analysis of inmate assignment and wage rates at four state prisons under executive orders of June 26 and August 29 covering classification and rates as of September 30, 1930. (Chart CPI-6.) Photostat copy. 


\section{New York. Prison Survey Committee.}

Report. Albany: J. B. Lyon, 1920.

Partial contents:- "Prison industries and production," ch. 3 . "Attitude of organized labor," ch. 4. "The use of farm and other state lands in connection with state prisons," ch. 5 . "Maintenance and upkeep," ch. 6. "Classification, supervision, and individual treatment of prisoners," ch. 7. "Wage and other incentives and compensation for industrial injuries;" ch. 9. "Market for prison-made goods," ch. 10. "Vocational training," ch. I2.

\section{- State Crime Commission.}

Report to the commission of the sub-commission on penal institutions, 1927-1929. Albany: J. B. Lyon, 1927-29.

Special report on penal institutions: 1930. Albany: J. B. Lyon, 1930.

Stenographic report of proceedings, November 21-22, 1929. MS copy, pp. 1312-1574.

[North Carolina.] State Prison Advisory Commission. Report of sub-committee of State Prison Advisory Commission; submitted to Governor O. Max Gardner; 1930.

[Pennsylvania.] Commission on Penal Institutions. Report, May 1931.

The prison labor problem; Pennsylvania's penitenTIARIES DEVELOPING CONSTRUCTIVE WORK PROGRAM FOR inmates. Philadelphia: Penna. Prison Soc. [1929].

Robinson, Louis N.

A financial survey of the state penal and correctional institutions in Pennsylvania; a report to the Citizens' Committee on the Finances of the State of Pennsylvania. December 1922.

\section{Wisconsin. Prison Labor Investigating Committee.}

Report. Madison: July I929.

\section{Reports of Institutions and State Agencies}

(Most of the adult penal and correctional institutions listed by the American Prison Association's official guide in April, I931 - excepting institutions recently opened or still in the course of construction - are covered here; about half a dozen established institutions do not publish their reports, and in a few other cases no copies of recent publications were obtainable.) 
Federal Penal and Correctional Institutions

Annual reports, 1928-30. Leavenworth: 1928-30.

Contains reports for United States penitentiaries at Leavenworth, Atlanta, McNeil Island; also for Alderson and Chillicothe reformatories.

Alabama. State Board of Administration.

Quadrennial reports, 1922-26. 1926-30. [Birmingham: 1922-30.]

Contain reports of convict department.

- State Prison Inspector.

Report, 1927-28. [Birmingham: 1928.]

Jail inspections.

Arkansas. State Penitentiary.

Report, 1926-28. [Little Rock: 1928.]

Little or no industrial data.

Arizona. State Prison.

No recent report obtainable.

California. State Board of Prison Directors.

Biennial report, 1927-28. Sacramento: 1928.

Folsom and San Quentin.

Colorado. State Penitentiary. Board of Corrections AND WARDEN.

Biennial report, 1927-28. Denver: 1929.

- State Reformatory. Board of Corrections and WARDEN.

Biennial reports, 1925-26, 1927-28. Denver: 1926-28.

Connecticut. Department of Public Welfare.

Report, 1927-28. Hartford: 1929.

- ReFormatory.

Report of the Directors, 1927-28. Hartford: 1928 .

- State Farm for Women.

Biennial reports of the Board of Directors, $1925-26,1927-28$, 1929-30 Hartford: 1926-30.

- State Prison.

Report of the Directors, 1925-26. Hartford: 1926. 
[Delaware.] New Castle County Workhouse. Board of TRUSTEES.

Reports, 1927-28, 1929-30. [Wilmington: 1929-31.]

This institution serves as Wilmington city jail, county workhouse, and state prison.

District of Columbia. Board of Public Welfare. Annual report, I929: D. C. penal institutions. Lorton, Virginia: [1929?]

Florida Department of Agriculture. Prison Division. Twentieth biennial report, 1927-28. Tallahassee: [1929?]

Georgia. Prison Commission.

Second biennial report, 1927-28.

Idaho. State Penitentiary.

Biennial report, 1927-28.

Illinois. Department of Public Welfare.

Twelfth annual report, 1928-29. [Springfield: 1930.]

Indiana. Board of State Charities.

Fortieth annual report, 1929. Indiana Bul. of Char. and Cor., no. I 82: 180-354 (May 1930).

. [Hospital for Insane Criminals.]

Indiana Hospital for Insane Criminals; established October 19, 1912. Michigan City: n.d.

Descriptive pamphlet.

- Reformatory.

Annual reports, 1928-29.

-. State Farm.

Fifteenth annual report, 1929. Fort Wayne: 1930.

- State Prison.

Annual reports, 1928-29. Michigan City: 1928-30.

Indiana State Prison. Michigan City: 1929.

Descriptive folder.

- Woman's Prison and Correctional Department.

Fifty-eighth annual report of prison and 20th annual report of correctional department, I929. Fort Wayne: 1930.

Iowa. Men's Reformatory.

No recent reports obtainable.

- State Penitentiary.

Forty-third biennial report of the Warden, 1927-28. 
Iowa. Women's Reformatory.

Fourth biennial report of the Superintendent, 1923-24; 6th biennial report, I927-28.

Kansas. State Industrial Farm for Women.

Sixth biennial report, I927-28.

- State Industrial Reformatory.

Seventeenth biennial report, I927-28.

- State Penitentiary.

Twenty-sixth biennial report, I927-28. Topeka: 1928 .

Kentucky. State Board of Charities and Corrections.

Report, 1928-29.

Louisiana. State Penitentiary.

No reports published recently, to the best of our knowledge.

Maine. Reformatory for Men.

- Reformatory FOR WOMEN.

- - State Prison.

No repurts published since 1923 .

Maryland. Board of Welfare.

Annual reports, 1928-29. [Baltimore: I929-30?]

- Department of Welfare. Director.

Fifth annual report of the inspection of the county jails of

Maryland, I929. Baltimore: I930.

Massachusetts. Commissioner of Correction.

Annual reports, 1925-1929. Boston: 1926-1930.

Reports on all correctional institutions included; good data on prison industrial finances.

Michigan. REFORMATORY.

- - State House of Correction and Branch Prison.

- State Prison.

No reports published of recent years.

- Detroit. House of Correction.

Annual reports, 1926, 1928, 1929. [Detroit: 1927-30.]

Minnesota. State Prison.

Biennial reports, 1927-28, 1929-30. Stillwater: 1928-30.

- State Reformatory.

Biennial reports, I925-26, I927-28. St. Cloud: 1926-28.

- State Reformatory for Women.

Fourth biennial report, 1927-28. Shakopee: [1928?]. 
Mississippi. State Penitentiary.

Biennial report of the Board of Trustees, Superintendent and other officers, $1927-29$.

Missouri. Department of Penal Institutions.

Biennial reports, 1925-26, 1927-28, I929-30. Jefferson City: rg26-3I.

- State Board of Charities and Corrections. Biennial reports, I925-26, I927-28. Jefferson City: 1927-29.

Montana. State Prison.

Biennial reports (with reports of Registrar of Motor Vehicles), 1925-26, 1927-28, 1929-30.

Nebraska State Penitentiary.

Biennial reports of the Warden, 1926-27, 1928-29. Lincoln: 1927-29.

- State Reformatory for Men.

- - State Reformatory for Women.

No recent reports obtained.

Nevada. Superintendent State Police and Warden State Penitentiaky.

Biennial reports, 1925-26, 1927-28. Carson City: I927-29.

New Hampshire. State Board of Charities and CorrecTION. (Now State Board of Public Welfare.)

Seventeenth biennial report, 1927-28. [Concord: I928?].

New Jersey. Department Institutions and Agencies. Five-year summary covering approximate period I $925-30$ in preparation. The Department supervises the State Prison, the Reformatory for Women, the State Reformatory at Rahway, and the State Reformatory at Annandale, also the two farms connected with the State Prison.

- Reformatory (Rahway).

Annual reports, 1926, I927. Rahway: 1927.

New Mexico. State Penitentiary. Board of CommisSIONERS and Superintendent.

Reports, 1927, 1928, 1929. Santa Fe: 1927-29.

New York. Institution for Defective Delinquents.

Annual reports of the Board of Managers, I925, I926, 1927. Albany: $19^{25}-27$. 


\section{BIBLIOGRAPHY}

New York. State Commission of Correction.

Second annual report, $192 \dot{8}$. [Ossining: 1929.]

North Carolina. The State's Prison.

Biennial report, 1927-28. Raleigh: 1928.

North Dakota. State Penitentiary.

No recent report obtainable.

Ohio. Department of Public Welfare.

Advance sheets: Sixth annual report, 1927. [Columbus: 1927.]

Seventh annual report, 1928. [Columbus: 1930?]

Eighth annual report, I929. [Columbus: I931 ?]

Orlahoma. Commissioner of Charities and Corrections. Report, 1929.

Contains reports of Oklahoma State Penitentiary and Oklahoma

State Reformatory.

Oregon. State Penitentiary.

Fourteenth biennial report, 1927-28. Salem: 1929 .

Pennsylvania. Eastern State Penitentiary.

Annual reports, I927, 1928, 1929. [Philadelphia: 1927-29.]

- Industrial Reformatory.

Biennial reports of the Board of Trustees, 1925-26, 1927-28. Huntingdon: [1927-29].

- State Industrial Home for Women.

Report of the Board of Trustees and Superintendent, 1924-28.

[Muncy: 1928.]

- Secretary of Welfare.

Biennial reports, 1925-26, 1927-28. Harrisburg: [1926-28?] Asylum.

Annual reports of the Managers, 1928,1929 .

Pennsylvania. Philadelphia County Prison.

Summary of activities of the Board of Inspectors, Philadelphia County Prison, during the year 1929, and the improvements during that period ... [Philadelphia: 1930.]

Rhode Island. State Prison and Providence County Jail. Annual reports, 1927, 1928, 1929. Providence: 1928-30.

- Public Welfare Commission.

State Reformatory for Women: Fourth annual report, 1927.

Providence: 1928 .

8.P.w. -23 
Rhode Island. Public Welfare Commission.

Excerpt of the $5^{\text {th }}$ annual report of the State Public Welfare Commission: Reformatory for Women, I928. Providence: I929. Excerpt of the 6th annual report: Reformatory for Women, 1929. Providence: 1930.

South Carolina. Board of Public Welfare.

Fifth annual report, 1924; vol. 4, no. 4. Columbia: 1925.

- Penitentiary.

Annual reports of the Board of Directors and Superintendent, 1927, 1928, 1929. Columbia: 1928-30.

South Dakota. Board of Charities and Correction. Twentieth biennial report, 1927-28. [Pierre: 1928.]

Tennessee. Department of Institutions.

Biennial reports, 1924-26, 1926-28. Nashville: [1926-28?].

Brushy Mountain Penitentiary and Tennessee State Penitentiary reports included.

Texas. Prison Board.

Annual reports, 1928, 1929. Huntsville: 1929-30.

Utah. State Prison.

Biennial report, 1927-28. [Salt Lake City: 1926-28.]

Vermont. Department of Public Welfare.

Biennial report, 1927-28. Rutland: 1928.

Includes reports of Vermont State Prison and House of Correction for Men, and Vermont State Prison and House of Correction for Women.

Virginia. Penitentiary.

Annual reports of the Board of Directors 1928, 1929. Richmond: 1928-29.

Including reports on the State Penitentiary Farm, the State Farm for Defective Misdemeanants, and the State Convict Road Force.

- State Board of Public Welfare.

Seventeenth annual report, 1926. Richmond: 1927.

Biennial report, 1927-29. Richmond: 1930.

Washington (state). Department of Business Control.

Biennial reports, 1924-26, 1926-28. Olympia: 1926-28.

Including reports of State Penitentiary and State Reformatory. 
West Virginia. Penitentiary.

Triennial statistical report, $1927-30$.

Very little labor data.

Wisconsin. State Prison.

Biennial reports, 1925-26, 1927-28. Waupun: 1926-28.

State Reformatory.

Sixteenth biennial report, ... being part of the biennial report of the State Board of Control of Wisconsin, 1927-28.

- Milwaukee County. House of Correction. Annual reports, 1928, I929 Milwaukee: 1929-30.

Wyoming. State Board of Charities and Reform.

Biennial reports, 1924-26, 1926-28, 1928-30. Cheyenne: 1926-30. 


\section{INDEX}

Accounting, 188-98, 210, 247, 297; importance of, $247,294^{-6}$; inaccuracies of, 49, 72, 188-90, 195,213

Advertising, 134-5

Alabama, 8 (note 1), 14, 26 (note 4), 26a-9, 33, 38, 41, 89-9o, I06, $123,128,205-6,219,224$, $236,267,271-2,304,308$

Alabama Prison System, 192, 235-6

Albion State Training School (New York), 9 (note 2), I44

Allegheny County Workhouse, 258-9

Allison, A. F., 7 r

Allocation of prison industries, 104-5, 107

American "Federation of Labor, $64-9,108,110-12,282$. See also Union labor, attitude of

American Prison Association, 10, I $18,140,142-3,159,179$

Anderson, Nels, 69 (note)

Andrews, John B., iv, 6I (note I), 133 (note 2), 223

Arizona, 15, 26 (note 2), 38, 4I, 123, 177 (note I), 204, 306, 310

Arizona State Prison, I 93, 208, 230

Arkansas, 8 (note I), I4, 26 (note I), 4I, I 23, 208, 267, 272, 304, 308

Arkansas Prison System, I92, 238

Arkansas State Farm for Women, 9 (note 2)

Associates for Government Service, Inc., $104^{-6}$, 108

Attica State Prison (New York), 139

Auburn Prison (New York), I7, 139, 170, 191, 212, 218, 223, 240,278
Auto tags, 19-20, 105-7, $11_{4}, 1_{32}$, $259,264,276-7,282,287$

Baer, Fred, 67

Bagley, Edward C. R., iv, 75, I35, 196 (note I), 214

Baker, Amos, I 43

Barnes, Harry Elmer, iv, 258-9, 294

Bennett, J. V., 40, 285 (note 5), 287

Berks County Prison (Pennsylvania), 184, 257, 279

Binder twine, $50,54,57,61,71-2$, $76-7,130,132,229,264,276$, $280-1$

Bloodgood, Ruth S., 21 5-16

Booth, Ernest, 37 (note 2), 274

Branham, V. C., I 4 I (note 2), I42 (notes), I 43, I 44 (notes), I 50 (note), $155^{-6}$

Brockway, Z. R., 3

Brooms and brushes, 59, 71, 250-I, 258-9, 264, 281

Brown, Roy M., II9 (notes I and 3), I 20 (note I), 273

Brushes see Brooms and brushes

Brushy Mountain Penitentiary (Tennessee), 129, 192, 237

California, I 5, 26 (note 3), 41, 47, $93,121,123,212,221,271$, 275, 306, 310

California State Prison (Folsom) 20, I21, I28, 193, 230, 266

Capital, 71, 132-3, 262, 287; cheap, 49, 94. See also Economic factors

Cass, E. R., iii, 2, 93 (note 3), ro8, 135 (note 2), 217 (note 2), 235 (note I), 298 (note)

Census, U. S. Bureau of the, 53 (note 3), 228 
Christianson, Theodore, iv, 77-8 (note I), 129

Clark, L. D., 285 (note I)

Classification need for, I38, I 56, I 77, 288 procedure, $145-6,168$ schemes of: administrative, I42-3, 148, I79; devised by American Prison Association, I40-3; in New Jersey, I 45 ff., I 55-6; in New York, 141-5, 148-52, I55-6; scientific, $142-3,178$

studies, $138 \mathrm{ff} ., 175$, I82; administrative, 140-3; Federal, 139; in New Jersey, 148, 156; in New York, 142-4, 156; of misdemeanants, I 77-82; psychiatric, see next item; scientific, $140-3,178$

Cleghorn, Sarah N., 238 (note 3)

Climate, influence of, I19, 127. See also Economic factors

Clinton Prison (New York), I7, I70, 191, 212, 21 8, 240

Colorado, I 5, 26 (note 2), 4I, 47, I06, I21, I23, 131, 275, 306, 310

Colorado State Penitentiary, 18 (also note 2), 20, 191, 204, 208, 230

Colorado State Reformatory, 192, 230

Commerce: U. S. Chamber of, 72 , I09; U. S. Department of, report by, 7, 52, 92, 189

Commission to Investigate Prison Administration and Construction (New York), I39, I4I

Commitments: distribution of, 42 ; length of, 259

Commons, John R., iv, 6I (note 2)

Compensation to prisoners: workmen's, 187, 221-7 (also note 2); for work performed see Wages and Wage scales. See also Laws affecting prison labor

Compensation to victims of crime, $3,199,215,295-6$
Competition with free industry, 48 ff., 70, 82, 93-100, 290-I, 301 ; affecting local production conditions, 54; extent of, $52-6 \mathrm{I}$; in certain lines, $54-8$, 62,2802 ; in New York (state), 59-60

Compulsory-purchase clause, IOI2, 122, 135. See also Systems of labor, state-use

Concentration of prison industries see Industries, concentration upon certain

Conferences, regional on prison labor, 105, I 1 7-1 8

Connecticut, 13, 26 (note 4), 26a$27,4 \mathrm{I}, 123,148,252,303,307$

Connecticut Reformatory, I32, 135, 161, 173, 191-2, I 95

Connecticut State Farm for Women, 138 , 192

Connecticut State Prison, I92

Connor, A. H., 215

Construction trades, 264

Construction work by prisoners, 255-7, 279-8I

Contract, a typical prison, 92

Contract system see Systems of labor

Cooley, Harris R., 25I (note 4)

Coöperation of trade groups, 69, Costs 291-4, 300; in France, 301

construction, 188

gross per capita see Costs, prison operating

industrial, I 86-7, 189-90, I95-8; separation of from prison costs, 195-8, 247, 295

labor, 49-5I, 88, 92, 94, 96, 187-9, 195-8, 297

net per capita see Costs, prison operating

penological, 187-8, 197, 247, 295 prison operating, $3,49,96,99$, I33, I 86 ff., 228, 235-47; lower in South, 246; per capita, 228-33. See also Economic factors

shipping, I27, I3I, I87, 287

Cox, William B., 245 (note 2) 
Cumberland Valley Institution (Pennsylvania), I38

Cut-make-and-trim system see Systems of labor

Dade County Jail (Florida), 36

Dannemora State Hospital (New York), 9 (note 2), I 44

Defective delinquents, I $37-40, I_{43}$, I 47-52, I 54, $170,178,180$, $182-3$

Delaware, 8 (note I), I4, 26 (note 2), 35, 4I, I23, 204, 267, 272, 304,308

Delaware County Jail (Pennsylvania), 184, 257

Dependent families of prisoners: case study of in Kentucky, 215-r6; problem of supporting, 2, 219, 296, 299.

Detroit House of Correction, 26-7, $29,34,4 \mathrm{I}, \mathrm{I77}, 260$

District of Columbia, 24, 26-7, 29, 3I, 4I, 107, 199-200

District of Columbia Jail, 26-26a, 259

District of Columbia Reformatory, 10, 259

District of Columbia Workhouse, $26-26 a, \mathrm{I} 84,250,259-60$

Distribution of employment by systems of labor, 82-7; in each state, 307-IO; in East, South, Middle West, West, $83-4,86-7,307-10$

Diversification of prison industry, $61,100,107,125,130,133$, 286, 288

Doll, Edgar A., 147, 150 (note), I 54

Earnings, industrial, 235-45; per capita, 229-34; relation of to prison accounts, 190-3; subject to legislative depredations, 193-5

Eastern Broom Manufacturers and Supply Dealers Association, $7 \mathrm{I}$

Eastern State Penitentiary (Pennsylvania), 103, I23 (note), I9I, I97, 2II, 240-I, 269, 279
Economic factors, 49, 94, $126 \mathrm{ff}$., 127, 187, 262. See also Capital, Climate, Costs, Markets, Materials

Economics and penology, close connection between, 294-6, 298. See also Economic factors

Education of prisoners, general, 3

Edwards, A. M., 69 (note)

Efficiency: of management, $9 \mathrm{I}$, 295, 30I; of prison shops, 22, $234-5$; U. S. Bureau of, 38 , $40,285-7$

Ellis, William J., I46 (note I), 147,150 (note), 300 (note)

Emmerson, Louis L., iv, 22, I3I

Employment

distribution of see Distribution of employment by systems of labor

extent of, $5-17,21-43$; by states, 8 (note I), 13-15, 97, 303-6; in county and municipal institutions, 24-43; in different parts of the country, II-I 5 , 3०3-6; in state and Federal institutions, 5-I 7, 21-4, 3036; not accurately estimated in official reports, 17

institutional, $6,8,10-13,15-16$, I8-19, 2I-3, 30, 32-3, 8I-4, 303-10

productive, $3 \circ$; as part of vocational training, 4, 166; extent of, 6-8, 10-16, 19-23, 33, $82-3,303-10$

questionnaire concerning, 25, 307.

statistics of: for period 18851923,6 ; for 1914,24 ; for $1923,5-6,16,85$; for 1926,7 , 16; for 1928, 8, 10-16, 85; from Federal sources, 5-9, 16, 24, 85; from 1929 Handbook, 9-16, 20-2; from state sources, 9, 25-9, 31-3; value of, 1622,32

types of see Work, kinds of

Erie County Penitentiary (New York), 255

Erskine, George C., I61, 173 
Examination of Prisoners, Massachusetts Division for, 179-81, 183

Executives, need for well-trained, 46

Expenses, prison see Costs, prison operating

Far West Manufacturing Company, II6-17

Farm work, 30, 77, 114, 237-9, $250-61,263,265-9,276$

Federal Industrial Institution for Women, 8, 138, 192, 270

Federal institutions, $8,12-13,16$, $83-4,121,139,201,204,228$, $262,269,271,275,285-6$. See also individual institutions

Federal Penal and Reformatory Institutions, Special Committee on: hearings before, 214; report by, 8

Feeble-minded delinquents see Defective delinquents

Financial aspects, importance of, 294-6, 298. See also Accounting

Fisher, Dorothy Canfield, 238 (note 3)

Fishman, Joseph F., iv, 32 (notes $I$ and 3$), 37-8,26 \mathrm{I}$

Florida, 8 (note I), 14, 26 (note 2), $35^{-6}, 38,4^{1}, 89$, I19, 123, 268, $27 \mathrm{x}-2,304,308$

Florida State Farm, I9I

Frayne, Hugh, 62, 285 (note 3)

Frey, John P., 63 (note 3), 158 (note 3)

Garment trades, 70, 97-8, 161, $165,263,276-7,281$. See also Work shirts

Garrett, Paul W., iv-v, 9 (note I), $78,134,172,174$

Georgia, 8 (note I), I4, 26 (note 4), 26a-9, 31-2, 41, 87, 107, II9, 123,177 (note 1), 200 . 208, 27I-2, 304, 308

Georgia State Prison Farm, I92, 241,267

Gill, Howard B., iv, 73, 74 (note I), 75, 133, 16r, 189, 234-5, 292
Glueck, Bernard, 155

Glueck, Eleanor, T., v, 163-4

Glueck, Sneldon, $v, 163-4$

Gompers, Samuel, 63 (note 3), 219

"Good time": as wages, 202-5, 207-8, 256, 297; as reward for good behavior, 207, 297.

Governors, 1930 conference of, iv, 22, 78 (note I), II 8

Great Meadow Prison (New York), 17, I70, I9I, 218, 240

Green, William, 66

Hammill, John, 77-8 (note I)

Handbook of American Prisons and Reformatories: $1929, \mathrm{v}, 9,16-$ 17, 19, 76, 89, 91, 160, 190, 20I, 230-I, 240, 243, 266, 269, 279

Hanson, Florence Curtis, 67

Hart, Hastings $\mathrm{H}_{\text {., }}$ 175, $30 \mathrm{I}$

Hawes-Cooper Bili, 65-6, 85, 104, $28 \mathrm{r}$; constitutionality of, 110 (note 3); protests against, II8; results of, II3-19, 260; text, 109

Hiller, E. T., 6I (note I)

Hodder, Jessie D., v, I 53-4

Huber Law (Wisconsin), 200

Hyneman, C. S., 208

Idaho, 8 (note I), 15, 26 (note 4), 26a, 4I, 89, 106, I 23, 209, 282, 306, 310

Idaho State Penitentiary, 160, 192, 243-4

Idleness, compulsory, I-2, 102 , 169, 194, 289, 299, 301; cruelty of, 2 ; demoralizing effects of, I; extent of, see Unemployment, extent of; semi-, I7, $19,22-4,103$

Illinois, 14, 26 (note 2), 27, 37, $41,47,93,123,208,305,309$

Illinois State Farm, 9 (note 2)

Illinois State Penitentiary, I9I, $241-2,279,282$

Illinois State Reformatory, 19I

Illinois Women's Prison, I93

Indeterminate sentence, relation of to employment problem, 136, 182,184 
Indiana, 14,26 (note 4), 26a-27, $4 \mathrm{I}, 47,93,123,260-1,278$, 305,309

Indiana Hospital for Insane Criminals, 148

Indiana Reformatory, 191, 209, 230, 279

Indiana State Farm, 9 (note 2), $26 a, 27,29,184,26 \mathrm{I}$

Indiana State Prison, 107, 115 , I49, I I I , 2 I I-I 2, 230, 242, 266

Indiana Woman's Prison, 192, 230

Individualization, basic principle of, $\mathrm{r} 66$

Industries: concentration upon certain, 54-9, 276, 280-1, 290; efficiency of see Efficiency; organization of, 175-7; selection of, $128,176,248,276-7$, 283-8; suitable for jails see Work, suggestions for; unsuitable for prison use, 283

Insane delinquents, $143^{-4}, 147-9$, I 54, I 78 , I 80, I $82-3$

Institution for Defective Delinquents (Napanoch, New York), 136, 138, 144, $150-1$ I 54, I69, I 93

Institutional work see Employment, institutional and Maintenance work

Iowa, 14,26 (note 2), 4I, 106, 123 , 305,309

Iowa Men's Reformatory, 193

Iowa State Penitentiary, I9I, 2 I I, 216 (note 3 ) 230,242

Iowa Women's Reformatory, 192

Jaffray, Julia K., 34 (note I), 199 (note 3), 260 (note 4)

Jails, as obstacles to employment, $44, \mathrm{I} 26, \mathrm{I} 83,248,262,30 \mathrm{I}-2$

Job analysis, 166-8, 175

Jobs available for prisoners see Work, kinds of and Production, types of industrial

Kangaroo court, 38

Kansas, 1 5, 26 (note 2), 37, 41, 106, I 23, 205-6, 219, 278, 305, 309

Kansas State Industrial Farm for Women, 192, 280
Kansas State Industrial Reformatory, IgI

Kansas State Penitentiary, 129, I91, 195, 21 5, 242, 280

Kennedy, John S., 33

Kentucky, 14, 26 (note 2), 38, $40-1,47,88,107,123,177$ (note 1), 198, 215-17, 273, 304,308

Kentucky State Board of Charities and Corrections, II 3-I4, 284

Kentucky State Penitentiary, 192, 230, 268

Kentucky State Reformatory, 192, 229, 23I, 268

Kirchwey, George W., iii, I10 (note 3)

Kirchwey, Karl W., 199 (note 3)

Labeling prison goods, 62,112

Labor: Commissioner of, reports by, 5 (note 1 ), 53 (note 4 ), 62 (note 2); costs see Costs, labor; forced, 29; skilled and unskilled, 137, 160-5, 262; supply, 88, I36-7; turnover, 136, 177, 235; U. S. Department of, data collected by, 5

Labor Statistics, U. S. Bureau of, reportsby, $5-7,24,52,70,79,85$

Lawes, Lewis E., I 28 (note 2), I39 (note 4)

Laws affecting prison labor, 29, $6 \mathrm{r}-2,69,88-9$, IOI-2, 108-r 3 , $125,133,171,186,198-9,213$, $221-6,282$; evasions and violations of, 69, 93, 102, 1 35, 253

Leach, Elmer J., 35 (notes I and 2)

Lease system see Systems of labor

Lee, Oscar, 137, 160

Leslie, Harry G., 77-8 (note I)

Lewis, Burdette G., 167 (note 1), I68 (note), 214

Liepmann, M., 258

Lima State Hospital for Criminal Insane (Ohio), 9 (note 2)

London Prison Farm (Ohio), 191, 194, 210, 279

Louisiana, 14, 26 (note 2), 4I, 88-9, $107,123,208,267,273,304,308$

Louisiana Prison System, 192, 236

Lovely, Collis, 63 (note 3 ) 
MacCormick, Austin H., iii, v, 9 (note I), 24, 74, 139 (note 5), $164-5,275,284$ (note I), 285 (note 2)

McCullough, E. W., 72, 108

McDonough, M. J., 67

McGrady, Edward F., 158 (note 3)

Machinery costs, $132-3$

Maine, 13, 26 (note 2), 40-1, I23, 208, 303, 307

Maine Reformatory for Women, 193

Maine State Prison, 193, 278

Maine State Reformatory for Men, 193,285

Maintenance: requirements, 18 , 168-71; trades, 264-5; work, 30, 32-3, 8I, 250-4. See also Employment, institutional

Management

divided, $17 x-6,220$

poor, forms of, $44-8,171$

problems of, $125 \mathrm{ff}$.; in institutions for misedmeanants, 177 ff., $183-4$

Manufacturers, attitude of: hostile, 48, 69-77; individual, 75 ; local, 73, 26I; official, 73; towards prison contracts, 93, 109; towards state-use system $72-6,112$

Manufacturers' Conference on Prison Industries, 108

Market price, $185-6$

Markets: availability of, $129-3 \mathrm{x}$; dumping of prison goods on, 97-8; restriction of, 99-100, I12-I3; under state-use system, 98, 102-4, I I 2-1 3, I 29-3 I

Maryland, 14,26 (note 4), 26a-27, 32, 4I, 47, 123, 177 (note 1 ), $211-12,216,224-6,273,304$, 308

Maryland House of Correction, I69, 192, 241, 268, 273, 278

Maryland Penitentiary, I16, I92, $241,268,273$

Mass production vs. limited production, 129-31

Massachusetts, 13,26 (note 4), $26 a-27,31,40-1,75,93,102-3$, $123,135,138,177,179-83$,
$185,195,200,204,213,217$, $224,233-5,251-2,292,303$, 307

Massachusetts Prison Camp and Hospital, 9 (note 2), 233-4

Massachusetts Reformatory, I 38 , I63-4, I9I, 23I, 233-4

Massachusetts Reformatory for Women, 138, I53, I9I, 231, 233-4

Massachusetts State Farm, 9 (note 2), $138,182,233-4$

Massachusetts State Prison, I 38 , I9I, 231, 233, 239-40, 269

Massachusetts State Prison Colony (Norfolk), 9 (note 2), 233-4, 279, 292

Massachusetts wage system see Wage systems

Materials, availability of, $127-9,287$

Matteawan State Hospital (New York), 9 (note 2), $\mathrm{I}_{44}$

Michigan, I5, 26 (note 2), 34, 37, $40-1,47,62,106,123,260$, 269, 27x, 275, 278, 305, 309

Michigan Reformatory, 193

Michigan State Federation of Women's Clubs, jail survey by, 34

Michigan State Prison, 19-2r, 63, 73, 19I, 278-9, 28I

Milliken, Ben H., 212 (note 2)

Milwaukee County House of Correction, $26-7,29,32,260$

Minnesota, $14-15,26$ (note 2), $41,76,93,107$, I I 2, I 23, I 29$30,165,186,276,278,305,309$

Minnesota State Prison, 50, 76-7, 129-30, 134-5, 191, 195, 217 , $229,231-2,238$

Minnesota State Reformatory, I 59, 19I, 210, 21 I

Minnesota State Reformatory for Women, I 53, I93, 23I

Mississippi, 14, 26 (note I), 4I, $107,123,208,267,273,304$, 308

Mississippi State Penitentiary, $192,236,246$

Missouri, 14, 26 (note 4), 26a, 28, $33,41,47,91,93,96,123,185$, 250-1, 278, 305, 309 
Missouri Department of Penal Institutions, 97, II $4^{-1} 5$

Missouri State Penitentiary, 90-I, 96-8, 191, 281

Mitchell, John, 63 (note 3)

Monahan, Florence, I 53

Montana, I 5, 26 (note I), 4I, 93, I 23, 208, 306, 310

Montana State Prison, I32, I9I, 244.

Moreschi, Joseph V., 67

National Commission on Law Observance and Enforcement, 47,88 (note I)

National Committee for Mental Hygiene, I77, I 83

National Committee on Prisons and Prison Labor, 81, I04, I09

National Society of Penal Information, iv-v, 9, 10

Nebraska, I4, 26 (note 3), 4I, I 23, I 85, 305, 309

Nebraska State Penitentiary, 192, 2II, 23I-2

Nebraska State Reformatory for Men, I92, 23I-2

Nebraska State Reformatory for Women, 192

Nevada, 8 (note I), I 5, 26 (note 2), $34,4 \mathrm{I}, 123,185,306,310$

Nevada State Penitentiary, I 93

New Castle County Workhouse (Delaware), I4, 35, I92, 211 , $237^{-8}, 272$

New Hampshire, I3, 26 (note 4), $26 a-27,37,41,123,200,224$, $252,303,307$

New Hampshire State Prison, I 93

New Jersey, 13, 26 (note 4), 26a$27,31,40-1,47,93$, 102-3, I 66, I I I-I 2, I 23, I 45 ff., I67-8, I79, 200, 219, 269, 275, 303, 307

New Jersey Reformatory (Annandale), 9 (note 2)

New Jersey State Prison, I06, I46, I67, I9I, 278,300

New Jersey State Prison Farm (Bordentown), 146

New Jersey State Prison Farm (Leesburg), I46
New Jersey State Reformatory (Rahway), I46, I93, 300

New Jersey State Reformatory for Women, 138, I46, I93, 2 I I

New Mexico, 8 (note I), I 5, 26 (note 4), 4I, 47, 107, 123, 208, 306,310

New Mexico State Penitentiary, I 22, 244

New York (city), 26-7, 29, 31-2, 4I, 93, I I I, I99-200

New York (state), I3, I9, 26 (note 4), 26a, 28, 3I-3, 37, 40-I, 47, $64,93,102-3$, I I I-I 2, I 23 , I34, I4 $1-5$, I 48-52, I 55-7, I 77-9, 1 83, 193, 200, 21 7-19, $223,253-6,269,271,275,282$, 303,307

New York Prison Survey Committee, 18, 157, 169-70, 196, 222,235

New York State Crime Commission: meeting of, iv, $78,16 \mathrm{r}$, 292; reports by, I7, 235

New York State Prison for Women, I44, I9I

New York State Reformatory, 139, I 44, I 93

New York State Reformatory for Women, I39, I44, I9I

Nonproductive employment see Employment, institutional

North Carolina, 14, 26 (note 4), 26a-27, 3I (also note I), 4I, 90, 107, I19, I23, 267, 27I, 273, 304, 308

North Carolina Industrial Farm Colony for Women, 9 (note 2)

North Carolina Prison System, 192, 236-7

North Dakota, I 5, 26 (note I), 4I, 93, I 23, 278, 305, 309

North Dakota State Penitentiary, 193

Obsolete plants see Plants, prison

Occupations see Work, kinds of

O'Hare, Kate Richards, 90, 96, I62

Ohio, I5, 26 (note 4), 26a-27, 31, $38-41,47,75-6,93,102-3$, 123, 177 (note I), 200, 21 I, 251, 305, 309 
Ohio Reformatory for Women, I9I

Ohio State Penitentiary, 128, I9I, $193-4,242$

Ohio State Reformatory, 19I

Ohl, Henry, Jr., 65-8

Oklahoma, 14, 26 (note 4), 26a, 28, $33,4 \mathrm{I}, 47,93,107,123,268$, $274,278,304,308$

Oklahoma State Penitentiary, 192

Oklahoma State Reformatory, 128 , 193,241

Opposition to prison industries: from contractors, 77 ; from farmers, 77-8, 282; from free labor, 48, 281-2, 291; from manufacturing interests, 48 , $73-7,246,281,291$; specific examples, $73,280-2$

Oregon, 15,26 (note 2), 41, 47, 93, $123,208,251,266,278,306$, 310

Oregon State Penitentiary, 191, 244

Overassignment, 17-23, 32, 235

Overcrowding, 46-8, 84

Overholser, Winfred, I 77 (note I), 179-80 (note I)

Overtask, 204, 212

Patterson, R. C., 32 (note 2)

Pennsylvania, 13, 17, 26 (note 4), $26 a, 28,3 \mathrm{I}, 37,40-1,47,93$, $103,105,112,120,123,172$, 177, 196-7, 200, 256, 303, 307

Pennsylvania Industrial Reformatory, 74, I9I

Pennsylvania State Industrial Home for Women, 138,192

Personnel, type of needed, 255, 294 Philadelphia County Prison, 257-8 Piece-price system see Systems of labor

Plants, prison, as obstacles to employment, $44-5,47,126$

Potter, Ellen C., 69 (note), 147

Price fixing, $185-6$

Prison, industrial function of, 171

Prison labor

discrepancy between theory and practice of, 289

public attitude toward, $v, 13$, 194, 289, 302; in Europe, 30I-2
Prisoner's interests are interests of society, $\mathbf{v}$

Prisoners: dependents of see $\mathrm{De}$ pendent families of prisoners; not working, allowance to, 204-6, 21 8-19 (see also Wages)

Prisons: per capita costs of see Costs, prison operating; U. S. Bureau of, 139

Production: per prisoner in New York, 59-60; ratio of prison to free, 53 (also note 4), 55-7; types of industrial, $263-4 \mathrm{ff}$; value of, $52-3,55-7,59-60$, 71,254 ; volume of, $51,55-7$.

Productive labor see Employment, productive

Profits: affected by diversification and market limitations, $\mathrm{I} 3 \mathrm{I}$; based on slave labor, 245, 247; difficulty of obtaining, 220; infrequency of, 229, 23I, 238, 245. See also Self-supporting institutions

Prosecution for evasion of stateuse laws see Systems of labor and Laws affecting prison labor

Psychiatric clinic, Sing Sing see Sing Sing Prison

Psychiatry, relation of to prison labor see Classification studies Psychopathic delinquents, I37, I43, I 47-9, I 50 (note), I 52-5, $178-80$

Public-account system see Systems of labor, state-account

Public-works-and-ways system see Systems of labor

Reclassification see Classification procedure

Reliance Manufacturing Company, 116

Responsibility for prison industries, 300, 302. See also Management, divided

Restoration, Pennsylvania Bureau of, $24 \mathrm{I}$

Restrictions on prison labor see Laws affecting prison labor

Revolving funds, $190-5,227,280$ 
Rhode Island, 13,26 (note 4), $26 a$ $28,35,40-1, I 24, I 77$ (note I), I 99-200, 209, 303, 307

Rhode Island Reformatory for Women, I93

Rhode Island State Prison and Providence County Jail, 94, I 92, 23I-2, 240

Road work, 24, 30-I, 237, 264-5, 267-70; extent of, 270-5; opposition to, 77; under local management, 249$50,256,260,262,271-5$; under state and Federal management, 268-70, 271-5. See also Systems of labor, publicworks-and-ways

Roosevelt, Franklin D., I4I

Ruger, T. H., 87

Russell, C., 25 I (note 4)

Sanford, Joseph W., 38-40

San Quentin Prison (California), I 8-I 9, I 21, I93, 207, 243, 266, 278

Schwartz, A. H., I IO (note 2), 222

Schwartz, Isaac Herman, 89 (note 5)

Self-supporting institutions, 50 , $236-8,245$; scarcity of, 50, 229, 233. See also Costs, prison operating and Profits

Selling prison products, $130,133-6$, 175

Sing Sing Prison (New York), 17, 128, 155, 170, I91, 212, 218 , 240; psychiatric clinic, I 39, I 43

Skilled labor see Labor, skilled and unskilled

Skills, industrial, 164

Slack, E. S., 207

Smith, Herbert L., iv

Sonsteby, John J., 63 (note 3 )

South Carolina, 14, 26 (note 2), 36, 4I, 89, II 9, I24, I 77 (note I), $271,274,304,308$

South Carolina Penitentiary, I I5, I 92, 237

South Dakota, 15, 26 (note 2), 4I, I06, 107, 1 24, 278, 305, 309

South Dakota Penitentiary, 17, I32, I II, 243
Southern Illinois Penitentiary, 191, 242

Squibb, Samuel, 66, 68

State House of Correction and Branch Prison (Michigan), IgI, 2 II

State-account system see Systems of labor

State-use system see Systems of labor

States-use system see Systems of labor

Statistics: difficulty of obtaining, 25-7; discrepancies of, 28; lack of, 5, 27. See also Employment, statistics of

Steiner, Jesse F., II9 (notes I and 3), 120 (note I), 273

Stern, Leon, I 20 (note 2), 256 (note I), 257 (notes)

Stillwater prison see Minnesota State Prison

Stockton, Frank J., 62 (note 3)

Stoecklein, E. V., 25I (note 4)

Subnormal type see Defective delinquents

Sullivan, J. J., 21 I (note 2)

Sutherland, Edwin H., I99 (note 2)

Systems of labor, I25, 246 afford no panacea, I 22 check list of, $123-4$ contract, $79-80,82-6,90-4,103$, I09, I I 2, II 7, I 23-4, 207, 212 , $232,236,240,266,277,296$, 307-10; illegal in Federal institutions and 17 states, 93, 96

cut-make-and-trim, 93, 98, II 5, 309

lease, 46, 79, 82-3, 85, 87-90, 93-4, 123-4, 296, 307-10 not clear-cut in practice, 90 piece-price, 80, 82, 86, 93-6, 109 privately-operated, 82,126 public-works-and-ways, 81, 836, 90 (note 2), II 24,249 , 307-10

self-sustaining, $8 \mathrm{I}-2$

state-account (public-account), 50, 80-7, 95-8, 103, 109, II 123-4, 1 27, 135, I7 I, 190, 236, 239, 307-10 


\section{INDEX}

Systems of labor (cont.)

state-managed, 82, $9 \mathrm{I}, \mathrm{I} 22$ state-use, $63,68,80-7,98-105$, I I I, I I9, I 22-4, I 27, I 7 I-2, I90, 277, 307-IO; degrees of success with, 75, 102-3; difficuities of administering, 46, IOI, IO3-4, 290-4; tendency towards, 45

states-use, 80-2, 104-8; criticism of, 108

Tannenbaum, Frank, 22

Task method, 91, 162

Tennessee, 14, 26 (note 4), 26a-27, $3 I, 4 I, 124,200,268,271,274$, 278, 304, 308

Tennessee State Penitentiary, 192, 209, 237, 278

Texas, 8 (note I), I4, 26 (note 2), $37,4 \mathrm{I}, 93,124,177$ (note I), I $99,208,267,274,304,308$

Texas Prison System, 192, 231, 238-9

Thayer, Dr. Walter N., Jr., I50 (note), $151-2,169$

Thomas, A. G., 285 (note 5), 287

Time-off, 297-8. See also "Good time"

Trade training see Vocational training

Trinkle, E. Lee, 106

Unemployment: causes of, $44 \mathrm{ff}$., I02-3; extent of, 6, 8, 10-12, 16-17, 20-4, 26a, 29, 32-4, $37-43,303-6$

Union labor, attitude of: coöperative, 69, 292-3, 300; hostile, 48, 6I-9; inconsistent, 68-9; local, 64, 26I; official, 64; towards state-use system, $63-9$ I 10-I 3; towardsstates-usesystem, II I; towards wages, 220

United States Industrial Reformatory, 8,270

United States Naval Prison (Portsmouth), 285

United States Penitentiary (Atlanta), 8, 128, 190, 210, 269-70

United States Penitentiary (Leavenworth), 8, 190, 210-11, 270
United States Penitentiary (McNeil Island), 8, 192, 270

Utah, 8 (note I), 15,26 (note 2), 4I, 93, I24, 204, 306, 310

Utah State Prison, I92, 204, 244

Vermont, 13, 26 (note 2), 4I, 124, 303,307

Vermont State Prison and House of Correction for Men, 9I-3, I 92,2 I I

Vermont State Prison and House of Correction for Women, 9 (note 2), 192, 238

Virginia, 14, 26 (note I), 36, 4I, 106, 124, 186, 209, 267, 27I, $275,304,308$

VirginiaState Farm, 36, I 84, I 92, 238

Virginia State Penitentiary, I 93

Vocational possibilities (New York), 157

Vocational training, 3-4, 100, 150 , 156-66, I 83, 298-9; as a means of reducing competition, 158-9; scope of, $165-6$

Wage

scales, 199-204, 206, 209-I 2, 220, 227; in New York, 21 8; usually experimental, I98

systems: Massachusetts, I95-6; New York, 196; Pennsylvania, 196-7; typical, 215

Wages, 1 36, 198-220, 235, 247, 295-8

as factor in production, $2 \mathrm{I} 2$

basis of, 198, 203-4, 206, 209-I 2; conduct as, 214 ; number of dependents as, 214; outside standard as, 219-20; theoretical, 212 ff., 219

deductions from, $196-7$

dependent on rate of profit, 213 , 219

for maintenance workers, $195-7$, 219

futility of in supporting dependents, 21 5-17, 219

importance of in program of rehabilitation, 295-6

in form of bonus payments, $9 \mathrm{I}$, 202-4, 206-9, 2 I I 
Wages (cont.)

now paid see Wage scales

prisoners receiving: in local institutions, 199-200; in state and Federal institutions, $20 I-8,218$

substitute for, $297-8$

Warden, function of, $171,174-6$

Washington (state), I 5, 26 (note 2), 4I, 47, 93, 106, I 24, I 86, 208, 306, 310

Washington State Penitentiary, I9-20, I93, 282

Washington State Reformatory, I I I

West Virginia, I4, 26 (note 2), 38, 4I, 47, I 24, I 77 (note I), 268, 275, 304, 308

West Virginia Penitentiary, I92, 229, 23I-2, 237, 269

Westchester County Penitentiary (New York), I84, 200, 250, 255

Western State Penitentiary (Pennsylvania), I9-21, 103, I69-70, IgI, 284

Weyand, L. D., I99 (note I), 219 (note)

Wheeler, Ruth Dunlop, 25 I (note 3)

Wheeler, W. C., I 28 (note I)

Williams, G. C., I 77 (note 2)

Wilson, Woodrow, 219

Wisconsin, I4, 26 (note 4), 26a, $28,41,47,64-8$, I I 2 , I 24,177 (note I), I85, 200, 224, 226, $278,305,309$

Wisconsin Board of Control, 65, 68

Wisconsin State Prison, I37-8, I91, 209, 243

Wisconsin State Reformatory, I9I
Women's Clubs, General Federation of, 109

Women's Clubs, Michigan State Federation of, jail survey by,

Work 34

as aid to discipline, 3

as foundation of training and care, 3-4, 289

as means of rehabilitation, $\mathrm{I}, 289$ as punishment, I

assignments, determination of, I 38, I 73, I 76

habit, $160,162,298$

kinds of: duplication of, 265; in East, South, Middle West, West, I3, 265-9; in local institutions, $30,248-61$; in special institutions, I 5I, I 54; in state and Federal institutions, 262-70; in typical jails, 250-7. See also Production, types of industrial

possibilities, 156

program, I43. See also Industries, organization of

shirts, 56-8, 70, 97, 232, 236, 240, 261, 266-7, 277. See also Garment trades

suggestions for, II $4,26 \mathrm{I}-2$, $282-5,287-8$

Working conditions, I33, I36, 296

Working day, length of, $17,31-3$, $61,125,173,176$

Worksheets, I 7, 20-I, 255-8, 266

Wyoming, I 5, 26 (note 2), 4I, II6, 1 24, 208-9, 306, 310

Wyoming State Penitentiary, I92, 



